КРАСИНСКИЙ ВЛАДИСЛАВ ВЯЧЕСЛАВОВИЧ

\title{
ПРАВОВОЕ ОБЕСПЕЧЕНИЕ ЗАЩИТЫ КОНСТИТУЦИОННОГО СТРОЯ РОССИИ В ИЗБИРАТЕЛЬНОМ ПРОЦЕССЕ
}

МОНОГРАФИЯ 
Рецензенты:

Волков В.П. - кандидат юридических наук, доцент, заслуженный юрист Российской Федерации, член Центральной избирательной комиссии Российской Федерации

Керимов А.Д. - доктор юридических наук, профессор, профессор кафедры государственного строительства и права Российской академии государственной службы при Президенте Российской Федерации

Шапиев С.М. - доктор юридических наук, профессор, Заслуженный юрист Российской Федерации, член Центральной избирательной комиссии Российской Федерации

Научный консультант: Дамаскин О.В. - доктор юридических наук, профессор, Заслуженный юрист Российской Федерации, профессор кафедры национальной безопасности Российской академии государственной службы при Президенте Российской Федерации

Красинский В.В. Правовое обеспечение защиты конституционного строя России в избирательном процессе. Монография. М.: Новый индекс, 2010. 332 с.

ISBN 978-5-88934-472-8 


\section{ОГЛАВЛЕНИЕ}

ВВЕДЕНИЕ

6

ГЛава 1. ТЕОРЕТИЧЕСКИЕ И НОРМАТИВНЫЕ ОСНОВЫ ПРАВОВОГО ОБЕСПЕЧЕНИЯ ВЫБОРОВ В ИНТЕРЕСАХ ЗАЩИТЫ КОНСТИТУЦИОННОГО СТРОЯ РОССИИ. 16

1.1. Выборы в системе народовластия России и их значение для защиты конституционного строя Российской Федерации .... 16

1.2. Теоретико-правовые аспекты регулирования (правового обеспечения) выборов в Российской Федерации

1.3. Содержание конституционно-правовой регламентации стадий избирательного процесса в интересах защиты конституционного строя России 79 ГЛава 2. ГЕНЕЗИС И ОБЩАЯ ХАРАКТЕРИСТИКА ПРОБЛЕМЫ ПРАВОВОГО ОБЕСПЕЧЕНИЯ ЗАЩИТЫ КОНСТИТУЦИОННОГО СТРОЯ В ПРОЦЕССЕ ОРГАНИЗАЦИИ И ПРОВЕДЕНИЯ ВЫБОРОВ В РОССИЙСКОЙ ФЕДЕРАЦИИ 122

2.1. Общее состояние правового обеспечения защиты конституционного строя в процессе организации и проведения выборов в Российской Федерации 122

2.2. Конституционно-правовой механизм защиты конституционного строя России в избирательном процессе 145

2.3. Нормативное правовое регулирование участия компетентных государственных органов и учреждений в защите конституционного строя России в избирательном процессе 169

Глава 3. ЗАРУБЕЖНЫЙ ОПЫТ НОРМАТИВНОГО ПРАВОВОГО ОБЕСПЕЧЕНИЯ ЗАЩИТЫ КОНСТИТУЦИОННОГО СТРОЯ В

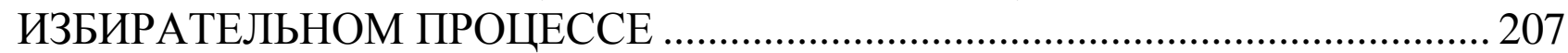

3.1. Международное правовое регулирование избирательного процесса..... 207

3.2. Правовое обеспечение избирательного процесса в зарубежных странах в интересах защиты конституционного строя 217

3.3. Национальное законодательство зарубежных стран об участии компетентных государственных органов и учреждений в защите конституционного строя в избирательном процессе 239

Глава 4. ОСНОВНЫЕ НАПРАВЛЕНИЯ РАЗВИТИЯ ПРАВОВОГО ОБЕСПЕЧЕНИЯ ЗАЩИТЫ КОНСТИТУЦИОННОГО СТРОЯ РОССИИ В ИЗБИРАТЕЛЬНОМ ПРОЦЕССЕ 255

4.1. Развитие правового обеспечения избирательного процесса в интересах защиты конституционного строя России. 255

4.2. Развитие иностранного (международного) и общественного контроля избирательного процесса в интересах защиты конституционного строя России 277 
4.3. Обеспечение конституционно-правовых гарантий легитимации избирательного процесса в интересах защиты конституционного строя России 293

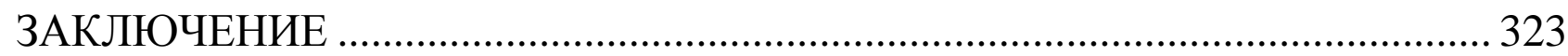

СПИСОК ИСПОЛЬЗОВАННЫХ ИСТОЧНИКОВ И ЛИТЕРАТУРЫ ............. 328

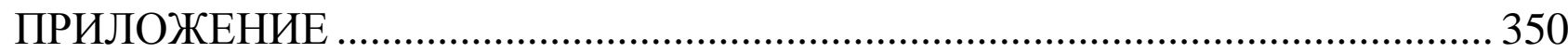

\section{ПЕРЕЧЕНЬ СОКРАЩЕНИЙ}

Федеральный закон от 6 октября 1999 г. (в ред. от 5 апреля 2010 г.) № 184-Ф3 «Об общих принципах организации законодательных (представительных) и исполнительных органов государственной власти субъектов Российской Федерации» - Федеральный закон от 6 октября 1999 г. № 184-Ф3

Федеральный закон от 12 июня 2002 г. (в ред. от 22 апреля 2010 г.) № 67-Ф3 «Об основных гарантиях избирательных прав и права на участие в референдуме граждан Российской Федерации» - Федеральный закон от 12 июня 2002 г. № 67$\Phi 3$

Федеральный закон от 10 января 2003 г. (в ред. от 22 апреля 2010 г.) № 19-Ф3 «О выборах Президента Российской Федерации» - Федеральный закон от 10 января 2003 г. № 19-Ф3

Федеральный закон от 18 мая 2005 г. (в ред. от 22 апреля 2010 г.) № 51-Ф3 «О выборах депутатов Государственной Думы Федерального Собрания Российской Федерации» - Федеральный закон от 18 мая 2005 г. № 51-Ф3

Постановление Правительства Российской Федерации от 25 августа 1999 г. № 937 «О содействии избирательным комиссиям в организации подготовки и проведения выборов депутатов Государственной Думы Федерального Собрания Российской Федерации»- Постановление Правительства Российской Федерации от 25 августа 1999 г. № 937

Постановление Правительства Российской Федерации от 13 января 2000 г. № 32 «О содействии избирательным комиссиям в организации подготовки и проведения выборов Президента Российской Федерации» - Постановление Правительства Российской Федерации от 13 января 2000 г. № 32

Постановление Правительства Российской Федерации от 5 сентября 2003 г. № 555 «О мерах по содействию избирательным комиссиям в организации подготовки и проведения выборов депутатов Государственной Думы Федерального Собрания Российской Федерации и Президента Российской Федерации» - Постановление Правительства Российской Федерации от 5 сентября 2003 г. № 555

Постановление Правительства Российской Федерации от 17 сентября 2007 г. № 589 «О мерах по оказанию содействия избирательным комиссиям в реализации их полномочий при подготовке и проведении выборов депутатов Государственной Думы Федерального Собрания Российской Федерации и Президента Российской Федерации» - Постановление Правительства Российской Федерации от 17 сентября 2007 г. № 589 


\section{ВВЕДЕНИЕ}

Защита конституционного строя России является важнейшим направлением государственной деятельности в политической сфере. Реализация стоящих перед государством задач по защите конституционного строя осуществляется постоянно, но особенно актуализируется в рамках избирательного процесса. Выборы играют ключевую роль в современной общественно-политической жизни нашей страны. Приход к власти представителей тех или иных политических сил с помощью выборов обусловливает определенное состояние защищенности конституционного строя. От решений, принимаемых органами народного представительства и выборными лицами, зависит распределение финансовых ресурсов, эффективность экономической деятельности хозяйствующих субъектов, степень реализации конституционных прав и свобод избирателей, характер средств и методов осуществления государственной власти.

В силу указанных свойств выборы попадают в зону повышенного интереса финансово-промышленных групп, радикальных организаций, представителей криминалитета, отдельных иностранных государств, неправительственных и международных организаций, преследующих в ходе избирательных кампаний цели, направленные на ослабление или подрыв конституционного строя России. Отдельные кандидаты и политические партии, стремясь любой ценой получить политическую власть, используют пробелы правового регулирования выборов, недостаточно четкие юридические формулировки ряда избирательных законов и прибегают к «грязным» избирательным технологиям. Все эти негативные явления подрывают доверие населения к избирательному процессу и формируемым представительным органам власти, что сказывается на стабильности политической системы и состоянии защищенности конституционного строя России.

Значимость и глубина исследуемой научной проблемы определяется необходимостью поиска сбалансированного подхода к обеспечению территориальной целостности, государственного суверенитета и общественной 
безопасности, с одной стороны, и развитию политического плюрализма, реализации конституционных прав и свобод участников выборов, с другой.

Президент Российской Федерации Д.А.Медведев в своей программной статье «Россия, вперед!» и Послании Федеральному Собранию Российской Федерации 12 ноября 2009 года указал на необходимость дальнейшего совершенствования политической системы Российской Федерации и защиты демократии в ходе избирательных кампаний. В качестве одного из векторов модернизации российской демократии глава государства выделил сохранение межпартийного консенсуса по стратегическим вопросам внешней политики, социальной стабильности, национальной безопасности, основ конституционного строя, охраны суверенитета нации, прав и свобод граждан, защиты права собственности, неприятия экстремизма, поддержки структур гражданского общества, всех форм самоорганизации и самоуправления ${ }^{1}$. Президент подчеркнул, что «демократия нуждается в защите» и обратил внимание на то, что «укрепление демократии не означает ослабления правопорядка»².

В настоящее время в отечественной юридической науке отсутствует представление о состоянии, потребностях, предмете, способах и пределах нормативного правового регулирования общественных отношений, возникающих в связи с обеспечением защиты конституционного строя России в избирательном процессе. Правоприменительная практика не позволяет в полном объеме осуществлять защиту конституционного строя в избирательном процессе, поскольку правовая политика государства в рассматриваемой предметной области носит характер фрагментарного рефлексивного реагирования на последствия негативных явлений, угрожающих конституционному строю России.

Анализ юридической литературы, посвященной теоретическим и прикладным вопросам защиты конституционного строя, позволяет сделать вывод об отсутствии единого подхода к правовому регулированию защиты конституционного строя Российской Федерации и неразработанности научно

\footnotetext{
${ }^{1}$ См. Рос. газ. 2009. 11 сентября.

${ }^{2}$ См. Рос. газ. 2009. 13 ноября.
} 
обоснованной концепции правового обеспечения защиты конституционного строя России в избирательном процессе. В связи с этим существует необходимость в теоретическом исследовании правового обеспечения защиты конституционного строя России в избирательном процессе.

Степень научной разработки темы. Особую ценность для научного исследования избирательного процесса с позиций защиты конституционного строя Российской Федерации представляют докторские диссертации и монографии А.И. Васильева, И.Н. Глебова, И.В. Гончарова, Р.Ф.Идрисова, А.А. Клишаса, В.В. Мамонова, А.Л. Пашина, Ю.О. Порошкиной, В.Л. Райгородского, В.П. Сальникова, С.В. Степашина, Т.Э.Шуберта, в которых исследованы общетеоретические вопросы конституционно-правового обеспечения защиты конституционного строя и национальной безопасности ${ }^{1}$. Специальные исследования в области методологии правового регулирования конституционноправовых основ национальной безопасности России провели В.Г. Вишняков, Л.В. Андриченко, С.А. Боголюбов и др ${ }^{2}$.

Значительная часть ученых-юристов разрабатывала отдельные аспекты правового обеспечения защиты конституционного строя в ходе выборов. Вопросы коррупции в избирательном процессе рассмотрены в работах С.Н. Бабурина, А.И. Волкова, Б.Л. Вишневского, Ю.В. Голика, И.А. Дамм, В.И. Карасева ${ }^{3}$. Процессы продвижения российскими организованными преступными группами своих

\footnotetext{
${ }^{1}$ См.: Васильев А.И., Сальников В.П., Степашин С.В. Национальная безопасность России: конституционное обеспечение. СПб., 1999; Глебов И.Н. Национальная безопасность Российской Федерации: проблемы правового регулирования. СПб., 2000; Гончаров И.В. Федеральное вмешательство в дела субъектов Федерации как средство обеспечения конституционной безопасности России. М., 2002; Идрисов Р.Ф. Теоретические и правовые проблемы обеспечения национальной безопасности Российской Федерации: Дис. ... докт. юрид. наук. М., 2002; A.A. Клишас. Конституционный контроль и конституционное правосудие в зарубежных странах: Дис. ... докт. юрид. наук. М., 2007; Мамонов B.B. Конституционные основы национальной безопасности Российской Федерации: Дис. ... докт. юрид. наук. Саратов, 2004; Пашин А.Л. Правовое обеспечение безопасности политической системы и личности в условиях глобализации рынка. Орел, 2005; Порошкина Ю.О. Проблемы законодательного обеспечения национальной безопасности Российской Федерации М., 2002; Райгородский В.Л. Национальная безопасность России: политико-правовые средства обеспечения. Ростов-н/Д., 2004; Шуберт Т.Э. Национальная безопасность России: конституционно-правовые аспекты. М., 2001.

${ }^{2}$ См.: Вишняков В.Г., Андриченко Л.В., Боголюбов С.А. и др. Национальная безопасность Российской Федерации: проблемы укрепления государственно-правовых основ // Журнал российского права. 2005. № 2; Вишняков B.Г. О методологических основах правового регулирования проблем безопасности Российской Федерации // Журнал российского права. 2005. № 9.

${ }^{3}$ См.: Бабурин С.Н., Голик Ю.В., Карасев В.И. Коррупция - наиболее опасный вектор деградации общества: Материалы к размышлению. М., 2004. 250 с; Волков А.И. Финансирование избирательных кампаний как один из источников политической коррупции // Выборы в Российской Федерации: [Материалы науч.-практ. конф. 16-17 марта 2002 г., Санкт-Петербург]. СПб., 2002. С.255-256; Вишневский Б.Л. Электоральная коррупция: формы, проявления, методы борьбы // Гражданское общество против коррупции в России. СПб., 2002. С. 238-255; Дамм И.А. Коррупция в российском избирательном процессе: понятие и противодействие. Автореф. дис. ... канд. юрид. наук. Красноярск, 2006. С. 15.
} 
кандидатов в органы государственной власти и местного самоуправления изучены А.И. Долговой, В.В. Астаниным, Д.И. Дзюбой, О.С. Ильиным, Р.Ю. Казаковым и др ${ }^{1}$. Проблемы правового обеспечения информационной безопасности подготовки и проведения выборов, механизмы противодействия избирательным технологиям манипулятивного воздействия на общественное сознание исследовали А.А. Коврижных, С.В. Мироненко, С.Ю. Савин².

В.П. Волков, О.В. Дамаскин, Р.Р. Сеченова и С.М. Шапиев разрабатывали организационно-правовые меры по совершенствованию формирования системы органов власти в избирательном процессе в интересах укрепления российской государственности, проанализировали гарантии законности и легитимности избирательного процесса в Российской Федерации, обосновали необходимость совместной деятельности правоохранительных органов и избирательных комиссий ${ }^{3}$.

Осуществлению международного наблюдения за выборами и направлениям его совершенствования в интересах защиты конституционного строя посвящены работы И.Б. Борисова, А.А. Вешнякова, И.А. Евланова, А.В. Иванченко, В.И. Лысенко, В.Е. Чурова и др ${ }^{4}$.

Особого внимания заслуживают научные исследования В.М. Баранова, А.Д. Болехивской, Н.С. Бондаря, И.Н. Гальвиной, В.Д. Зорькина, Д.С. Коровинских, Н.А. Ткачевой, Ю.Л. Шульженко, в которых предпринята попытка раскрыть

${ }^{1}$ См.: Долгова А.И., Астанин В.В., Дзюба Д.И., Ильин О.С., Казаков Р.Ю. Деятельность организованной преступности в политической сфере жизни общества // Организованная преступность, миграция, политика. М. 2002. C. 74

2 См.: Kоврижных A.A. Обеспечение информационной безопасности подготовки и проведения выборов (референдума) в условиях применения Государственной автоматизированной системы Российской Федерации «Выборы»: дис. ...канд. юрид. наук. М., 2004. 179 с; Мироненко С.В. Понятие «безопасность избирательной кампании» // Вестник Самарского государственного аэрокосмического университета. 2004. № 2. С. 26-38; Савин С.Ю. Правовое обеспечение информационной безопасности Государственной автоматизированной системы Российской Федерации «Выборы»: дис. ...канд. юрид. наук / РАГС при Президенте РФ. М., 2007. 184 с.

${ }^{3}$ См.: Волков В.П., Дамаскин О.В., Сеченова Р.Р. Обеспечение конституционной законности избирательного процесса в интересах безопасности государственного строительства. М.: Норма, 2007. 144 с; Волков В.П., Дамаскин O.В., Шапиев С.M. Некоторые проблемы и пути их решения для обеспечения законности избирательного процесса в Российской Федерации. М.: РЦОИТ, 2009. 288 с; Дамаскин О.В. Россия в современном мире: проблемы национальной безопасности. М.: Наука, 2007. 429 с; Дамаскин О.В. Легитимация результатов избирательного процесса в Российской Федерации // Журнал о выборах. 2008. № 3.

${ }^{4}$ См.: Борисов И.Б. Электоральный суверенитет или внешнее управление // Профиль. 2008. № 22. С. 22-23; Борисов И.Б. Ведут ли уличные акции к прямому народовластию // Рос. газ. 2009. 20 февраля; Вешняков A.A. Новые избирательные технологии и проблемы наблюдения за выборами // Журнал о выборах. 2005. № 3. С. 54-59; Иванченко A.B. Национальные выборы и принципы международного наблюдения // Журнал о выборах. 2008. № 5 . С. 43-47; Лыссенко В.И., Евланов И.А. Выборы - по демократическим стандартам // Журнал о выборах. 2005. № 3. С. 58-59; Лысенко В.И., Евланов И.А. Новый шаг в развитии международных избирательных стандартов // Журнал о выборах. 2008. № 6. С. 8-16; Чуров B.E. Суверенная демократия и выборы // Рос. газ. 2007.30 марта. 
современную сущность конституционного строя Российской Федерации и показать отношения, возникающие в связи с его защитой ${ }^{1}$. Актуальные проблемы взаимодействия государственных органов по линии защиты конституционного строя изучены Н.Т. Ведерниковым, В.В. Шалыгиным и А.В. Юдиным². В зарубежной юридической и общественно-политической литературе исследования, связанные с тематикой работы, проводились по двум основным направлениям. В рамках первого направления ученые-юристы анализировали проблемы правового регулирования выборов (Дж. Берри, Дж. Бойер, Р. Вилльямс, К. Джэнда, Дж. Голдмен, Дж. Зиммерман и др.) ${ }^{3}$. Второе направление охватывало нарушения законодательства о выборах, юридическую ответственность и вопросы укрепления законности избирательного процесса (К. де Бри, Г. Вевер, У. Клуссманн, Р. Маркус, Г. Масколо, Дж. Най, Р. Флоттау и др.) ${ }^{4}$. Вопросы защиты конституционного строя в избирательном процессе и правовая основа такой деятельности в качестве предмета самостоятельных исследований не рассматривались.

\section{Научная проблема исследования состоит в теоретическом обосновании} потребностей и возможностей развития механизма выборов как объекта защиты

1 См.: Баранов В.М., Бондарь Н.С. Конституционная безопасность и ее обеспечение в деятельности Конституционного Суда России: теория и практика // Вестник Нижегород. Академии МВД России. Н. Новгород, 2003. № 3. С. 10-18; Болехивская А.Д. Правовая охрана Конституции Российской Федерации: Дис. ...канд. юрид. наук. Волгоград, 2006. 201 с; Бондарь Н.С. Конституционный строй Российской Федерации и роль Конституционного Суда в его защите // Современный конституционализм. Тирасполь, 2006. № 1. С. 20-31; Гальвина И.Н. Охрана и защита конституционного строя Российской Федерации. Автореф. дис. ... канд. юрид. наук. Челябинск, 2006. 26 с; Зорькин В.Д. Защита конституционных основ публичной власти и политических прав граждан в практике Конституционного Суда России // Конституционное правосудие в новом тысячелетии. Ереван: НЖАР, 2005. С. 55-67; Коровинских Д.С. Правовая охрана Конституции Российской Федерации: Автореф. дис. ... канд. юрид. наук. М., 2005. 24 с; Ткачева Н.А. Проблемы гарантированности основ конституционного строя: Дис. ...канд. юрид. наук. Ставрополь, 2004. 179 с; Шульженко Ю.Л. Самоохрана Конституции Российской Федерации. М., $1997.62 \mathrm{c}$.

2 См.: Ведерников H.T. Конституционный суд и правовая защита конституционного строя // Конституционный вестник. 1991. № 8. С. 44-47; Шалыгин В.В. Особенности создания и деятельности специальных подразделений по защите конституционного строя и поддержанию правопорядка в зарубежных странах // Вестник Уфимского юридического института МВД России. 2008. № 1. С. 63-67; Юдин А.В. К вопросу о взаимодействии Вооруженных Сил Российской Федерации и Внутренних войск МВД России при защите конституционного строя // Право в Вооруженных Силах. 2005. № 8. С. 12-14.

3 См.: Берри Дж., Джэнда К., Голдмен Дж. Проблемы демократии. Форма правления в Америке // Технология и организация выборных кампаний. Зарубежный и отечественный опыт. Рос. акад. управления, Политологич. центр. М., 1993. С. 33-48; Boyer J.P. The Case for Election Law Reform, Parliamentary Government. Vol. 8, Summer, 1981; Зиммерман Дж. Прямая демократия в США: опыт и проблемы / Пер. с англ. А. Зябрева // Вестник Моск. ун-та. Сер. 11: Право. 1991. № 5. С. 47-55; Williams R. Party Finance and Political corruption. Polgrave Macmillan, 2000.

4 См.: Кристиан де Бри. Государство, мафиозные структуры и транснациональные корпорации // Муждународное право. 2000. № 3. С. 176, 181; Wewer G. Politische Korruption // Politic-Lexicon. Muenchen: Wien. Oldenborg Vlg, 1994. S.481; Renate Flottau, Erich Follath, Uwe Klussmann, Georg Mascolo, Walter Mayr, Christian Neef. Die Revolutions-GmbH: Helden unserer Zeit - wie eine neue Generation autokratische Regime in Osteuropa und Zentralasien stuerzt // Der Spiegel. 46/2005 vom 14.11.2005. S. 178; Nye J. Corruption and political development: a costbenefit analysis // American Political Science. 1967. № 12. P. 417. 
конституционного строя России в сфере организации и функционирования государственной власти, разработке теоретических положений и правовых мер защиты конституционного строя России в избирательном процессе.

Гипотеза исследования обусловлена предположением о том, что действующее законодательство и правоприменительная практика не в полной мере отвечают возрастающим потребностям в защите конституционного строя России в избирательном процессе, что требует разработки научно обоснованной концепции защиты конституционного строя России в избирательном процессе и выработки правовых мер развития правового обеспечения защиты конституционного строя России в избирательном процессе.

Объектом исследования являются общественные отношения, возникающие в связи с обеспечением защиты конституционного строя России в избирательном процессе.

Предметом исследования является нормативное правовое обеспечение защиты конституционного строя России в избирательном процессе.

Целью исследования является: теоретико-правовое обоснование места и роли института выборов в России как объекта защиты конституционного строя в сфере организации и функционирования государственной власти; раскрытие конституционно-правового механизма защиты конституционного строя России в избирательном процессе; выработка теоретических положений и правовых мер по совершенствованию нормативного правового обеспечения защиты конституционного строя России в избирательном процессе.

Для достижения цели исследования требовалось решить следующие научные задачи:

- определить значение выборов для защиты конституционного строя России;

- раскрыть содержание конституционно-правовой регламентации стадий избирательного процесса в интересах защиты конституционного строя России; 
- исследовать особенности, структуру и функционирование конституционно-правового механизма защиты конституционного строя России в избирательном процессе;

- рассмотреть нормативную правовую основу защиты конституционного строя России в избирательном процессе;

- показать нормативное правовое регулирование участия компетентных государственных органов и учреждений в защите конституционного строя России в избирательном процессе;

- выявить недостатки в нормативном правовом регулировании выборов в Российской Федерации, пробелы и коллизии, затрудняющие правоприменительную деятельность компетентных государственных органов и учреждений в условиях избирательного процесса, внести предложения по их устранению;

- рассмотреть международные документы и национальное законодательство зарубежных стран, регламентирующие организацию и проведение выборов в интересах защиты конституционного строя;

- обосновать теоретические положения и правовые меры, составляющие авторскую концепцию развития правового обеспечения защиты конституционного строя России в избирательном процессе.

Теоретическую основу монографии составили труды отечественных и зарубежных ученых, посвященные общей теории государства и права, конституционному и муниципальному праву.

Монографическое исследование основано на результатах анализа основных работ по данной теме С.А. Авакьяна, А.С. Автономова, С.Н. Бабурина, М.В. Баглая, И.Н. Барцица, Н.А. Бобровой, Н.А. Богдановой, Н.С. Бондаря, В.И. Васильева, Ю.А. Веденеева, Н.Т. Ведерникова, А.А. Вешнякова, В.Г. Вишнякова, В.П. Волкова, К.К. Гасанова, О.В. Дамаскина, Ю.А. Дмитриева, В.Д. Зорькина, А.В. Иванченко, Д.А. Керимова, А.Д. Керимова, Ю.Н. Климовой, С.Д. Князева, А.И. Ковлера, Е.И. Козловой, Е.И. Колюшина, И.Н. Куксина, О.Е. Кутафина, В.И. Лафитского, В.О. Лучина, В.И. Лысенко, В.В. Маклакова, Г.В. Мальцева, Н.И. 
Матузова, Н.А. Михалевой, Л.А. Окунькова, А.М. Осавелюка, Д.С. Петренко, А.Е. Постникова, А.С. Прудникова, Б.А. Страшуна, Ю.А. Тихомирова, Б.Н. Топорнина, А.Д. Урсула, Н.П. Фарберова, Т.Я. Хабриевой, В.Е. Чиркина, Т.М. Шамбы, С.М. Шапиева, К.Ф. Шеремета, Ю.Л. Шульженко и др.

При подготовке работы использованы результаты исследований зарубежных авторов, таких как М. Вебер, Р. Вильямс, К. Джэнда, М. Дюверже, У. Клуссманн и др.

Методологическую основу исследования составили всеобщие (диалектический, исторический), общенаучные (системный, статистический и др.) и частно-научные (формально-юридический, сравнительно-правовой) методы исследования государственно-правовых явлений и процессов.

Правовая основа исследования включает: Конституцию Российской Федерации, международные акты, федеральное избирательное законодательство, нормативные правовые акты Центральной избирательной комиссии Российской Федерации, нормативные правовые акты компетентных государственных органов и учреждений, оказывающих содействие избирательным комиссиям в подготовке и проведении выборов, законодательство субъектов Российской Федерации о выборах, национальное законодательство зарубежных стран о выборах.

Эмпирическая база работы основана на 75 постановлениях и определениях Конституционного Суда Российской Федерации, 40 решениях Верховного Суда Российской Федерации и судебных постановлениях других судов общей юрисдикции; материалах социологических исследований ФОМ, ВЦИОМ и ЛевадаЦентра; материалах прокурорско-следственной практики и электоральной статистики ЦИК России.

Научная новизна исследования заключается в том, что в нем впервые предложено решение крупной проблемы в области обеспечения защиты конституционного строя в избирательном процессе, имеющей важное научное, практическое и общественно-политической значение. Впервые в юридической науке сформулированы понятия правового обеспечения защиты конституционного строя России в избирательном процессе, конституционно- 
правового механизма защиты конституционного строя России в избирательном процессе; выявлены и раскрыты угрозы конституционному строю России, возникающие в избирательном процессе; обоснован конституционно-правовой механизм защиты конституционного строя России в избирательном процессе; определены функции, задачи и полномочия компетентных государственных органов и учреждений - субъектов защиты конституционного строя России в избирательном процессе; выявлены коллизии и пробелы законодательства о выборах в России в контексте защиты конституционного строя. Научная новизна проявилась и в сравнительном исследовании зарубежного опыта правового регулирования избирательного процесса в интересах защиты конституционного строя, а также в разработке теоретических положений и правовых мер по развитию системы федеральных и региональных нормативных правовых актов, регулирующих защиту конституционного строя в условиях выборов и образующих в совокупности авторскую концепцию развития правового обеспечения защиты конституционного строя России в избирательном процессе.

Теоретическая значимость работы заключается в том, что в ней научно обоснована необходимость защиты конституционного строя в избирательном процессе; раскрыт конституционно-правовой защиты конституционного строя России в избирательном процессе; показано состояние нормативной правовой основы защиты конституционного строя России в избирательном процессе; выявлены проблемы нормотворчества избирательных комиссий; выделена система субъектов, осуществляющих защиту конституционного строя России в ходе выборов; раскрыты предметы ведения и полномочия компетентных государственных органов и учреждений по защите конституционного строя России в избирательном процессе; определены факторы, влияющие на качество и эффективность нормативного правового обеспечения защиты конституционного строя России в избирательном процессе; показаны недостатки законодательных и подзаконных нормативных правовых актов, регламентирующих отношения, возникающие в связи $\quad$ с защитой конституционного строя России в избирательном процессе. 
Практическая значимость исследования состоит в том, что автором на основе обобщения практики применения норм избирательного права разработаны предложения по совершенствованию законодательства и подзаконных нормативных правовых актов в интересах защиты конституционного строя России; выделены направления совершенствования нормотворческой деятельности избирательных комиссий; подготовлены рекомендации о реформировании института иностранного (международного) наблюдения за выборами. Работа может представлять интерес и для преподавательской деятельности в образовательных учреждениях высшего профессионального образования в рамках курсов «Конституционное право России», «Конституционное право зарубежных стран», «Избирательное право и избирательный процесс в Российской Федерации», «Зарубежное избирательное право».

Цель, задачи и материал исследования определили структуру монографии, которая состоит из введения, четырех глав, заключения, списка использованных источников и литературы, приложений. 


\section{ГЛАВа 1. ТЕОРЕТИЧЕСКИЕ И НОРМАТИВНЫЕ ОСНОВЫ ПРАВОВОГО ОБЕСПЕЧЕНИЯ ВЫБОРОВ В ИНТЕРЕСАХ ЗАЩИТЫ КОНСТИТУЦИОННОГО СТРОЯ РОССИИ}

\section{1. Выборы в системе народовластия России и их значение для защиты конституционного строя Российской Федерации}

В соответствии с конституционным законодательством выборы занимают особое место в системе современного народовластия в России. В части 3 статьи 3 Конституции Российской Федерации референдум и свободные выборы провозглашаются как высшее непосредственное выражение власти народа.

Пункт 9 статьи 2 Федерального закона от 12 июня 2002 г. № 67-Ф3 закрепляет выборы в Российской Федерации как форму прямого волеизъявления граждан, осуществляемого в соответствии с Конституцией Российской Федерации, федеральными законами, конституциями (уставами), законами субъектов Российской Федерации, уставами муниципальных образований в целях формирования органа государственной власти, органа местного самоуправления или наделения полномочиями должностного лица.

Нужно отметить, что приведенные конституционно-правовые положения о народовластии пока еще являются политической программой, а не реальностью. Выборы в Российской Федерации лишь отчасти выступают инструментом реализации народного суверенитета. На низкое качество народного представительства, его обусловленность социально-экономическими факторами, незрелостью гражданского общества и неразвитостью политической культуры граждан неоднократно указывал и Президент Российской Федерации. «Чем «умнее», интеллектуальнее, эффективнее будет наша экономика, тем выше будет уровень благосостояния наших граждан. Тем свободнее, справедливее, гуманнее будет наша политическая система. Общество в целом. ... Политическую культуру не переделать простым подражанием политическим обычаям передовых обществ. Никто не проживет нашу жизнь за нас. Никто не станет за нас свободными, успешными, ответственными» ${ }^{1}$.

\footnotetext{
${ }^{1}$ См. Рос. газ. 2009. 11 сентября.
} 
В отечественном избирательном праве под выборами традиционно понимается институт (форма) непосредственного народовластия, посредством которой граждане реализуют свое конституционное право избирать и быть избранными в органы государственной власти и органы местного самоуправления, участвовать в управлении делами государства как непосредственно, так и через своих представителей ${ }^{1}$.

Некоторые исследователи более узко определяют сущность выборов. Так, А.А. Торшенко и В.А. Трегубенков полагают, что выборы представляют собой «способ обязательного, регулярного воспроизводства аппарата публичной власти путем самостоятельного, свободного избрания гражданами в статусе избирателей, выборщиков, депутатов представительных органов власти и выборных должностных лиц» ${ }^{2}$. Такая позиция заслуживает внимания, поскольку может быть применена к различным видам и уровням выборов. В то же время, данное определение не охватывает характеристику выборов как способа реализации избирательной правосубъектности граждан.

Следует констатировать, что реализация гражданами своих конституционных прав на участие в выборах осуществляется не на должном уровне. Развитие партийной системы в России усложнило возможности реализации ряда избирательных прав граждан, к числу которых относятся право быть избранным, участвовать в выдвижении кандидатов (списков кандидатов), осуществлять наблюдение за выборами. Лишение избирателей, не являющихся членами политических партий, права самовыдвижения кандидатами на выборах в Государственную Думу Федерального Собрания Российской Федерации, нарушило равенство политических прав партийных и беспартийных граждан Российской Федерации. Попытка законодателя закрепить гарантии реализации пассивного избирательного права граждан, не являющихся членами политических партий, в статье 37 Федерального закона от 18 мая 2005 г. № 51-Ф3 не изменила

\footnotetext{
${ }^{1}$ См.: Постников А.Е. Избирательное право России. М., 1996. С. 21; Избирательное право и избирательный процесс в Российской Федерации / Под ред. А.В. Иванченко. М.: Норма, 1999. С. 11; Избирательное право и избирательный процесс в Российской Федерации / Под ред. А.А. Вешнякова. М.: Норма, 2003. С. 12.

2 См.: Торшенко А.A., Трегубенков В.A. Понятие выборов в Российской Федерации // Российский юридический журнал. 2001. № 2. С. 45.
} 
ситуацию, поскольку решение политической партии о включении беспартийных граждан в выдвигаемый ею федеральный список кандидатов зависит от позиции руководства данной политической партии и не имеет перспектив обжалования. В этой связи можно согласиться с С.Н. Бабуриным, Н.Т. Ведерниковым, О.В. Голиком, Л.М. Карапетяном и А.М.Моисеевым, которые отмечают, что такое установление означает принуждение гражданина к вступлению в партию ${ }^{1}$. Размышляя об этом, С.А. Авакьян пишет, что «в случае избрания положение беспартийного становится вообще непонятным: он не только включается в состав партийной фракции в Государственной Думе, но и работает по ее правилам, а при их несоблюдении будет исключен из фракции с автоматическим прекращением его полномочий как депутата»².

Вряд ли соответствуют демократическому предназначению выборов правовые нормы действующих законов, не предусматривающие права выдвижения кандидатов избирателями и группами избирателей ${ }^{3}$ Федеральный закон от 18 мая 2005 г. № 51-Ф3 сохранил право направлять своих представителей в качестве наблюдателей за ходом голосования и подсчета голосов только за политическими партиями, зарегистрировавшими федеральные списки кандидатов. Данное решение законодателя представляется ошибочным, поскольку независимое общественное наблюдение за выборами могло бы способствовать защите избирательных прав граждан и демократизации политической системы Российской Федерации.

Но характеристика выборов как формы осуществления непосредственного народовластия не сводится только к избранию народных представителей в органы государственной власти и органы местного самоуправления. Выборы должны обеспечивать сознательное формулирование народом своей воли и контроль за ее

${ }^{1}$ См.: Бабурин С.Н., Голик Ю.В., Карапетян Л.М. Партизация государства как путь деградации общества / Актуальные проблемы современного российского государствоведения: сб. научных трудов. Вып. 2. М.: Изд-во РГТЭУ, 2009. С. 275-276; Ведерников H.T., Моисеев А.М. Соблюдение конституционного принципа свободы деятельности общественных объединений при реализации права граждан на объединение в политические партии / Румянцевские чтения. Государство и церковь: конституционно-правовые и богословские проблемы. М.: Изд-во РГТЭУ, 2009. С. 80, 82.

${ }^{2}$ См.: Авакьян С.A. Десять конституционно-правовых «заповедей» законотворчества // Вестник Московского ун-та. Серия право. 2010. № 1. С. 24.

${ }^{3}$ Исключение составляет статья 34 Федерального закона «О выборах Президента Российской Федерации». 
реализацией. С учетом этого С.Д. Князев предлагает рассматривать выборы как «императивный институт народовластия» ${ }^{1}$.

Данная точка зрения требует дополнительной аргументации, поскольку при отсутствии механизма отзыва депутатов и выборных лиц различных уровней формулирование народом своей воли и реализация устраивающего его политического курса представляются затруднительными и, как правило, подменяются искусным навязыванием большинству общества решения, фактически принятого той или иной корпоративной политической группой.

Следует согласиться с Ю.А. Веденеевым в том, что «феномен политически и юридически недостроенных партий тем и опасен, что, имитируя участие в избирательном, парламентском и законотворческом процессах, он фактически предоставляет узким социальным группам (корпорациям и лоббирующим их интересы лицам) и государственной администрации возможность совместно пользоваться государственными и экономическими институтами, властью и собственностью вне какого бы то ни было политического и юридического контроля со стороны гражданского общества или того, что от него остается» ${ }^{2}$.

Некоторые российские государствоведы определяют выборы через их социально-политическое значение. В частности, как отмечает Ю.А.Веденеев, «выборы - это институт и процесс принятия политико-правовых решений ...посредством которого осуществляется публичное политическое воспроизводство самого государства, а именно социальная ротация или перераспределение (перегруппировка или передача) законодательных и правительственных функций и полномочий» ${ }^{3}$. Социальная функция выборов состоит еще и в том, что они являются одним из эффективных инструментов политической самоорганизации граждан. Массовость, регулярность избирательных кампаний, актуальность обсуждаемых вопросов обусловливают их возможности как каналов косвенного влияния граждан на политический процесс в государстве.

\footnotetext{
№ 5. C. 36 .

2 См.: Веденеев Ю.А. Политические партии в избирательном процессе: правовые иллюзии и юридическая реальность // Государство и право. 1995. № 7. С. 26.

${ }^{3}$ См.: Реформа избирательной системы в Италии и России: опыт и перспективы. М.: Институт государства и права Российской академии наук, 1995. С. 84, 85.
} 
Недооценка социальной составляющей выборов является недопустимой. В качестве примера можно привести ситуацию, когда ангажированность средств массовой информации, отсутствие достойных кандидатов, конструктивных программ политических партий, бесконечные невыполняемые обещания политиков вызывают «усталость» избирателей и отторжение от выборов, что сказывается на снижении явки. Предпринятые федеральным законодателем меры по отмене порога явки на выборах и возможности голосования против всех кандидатов создали иллюзию решения данной проблемы с помощью игнорирования протестных настроений избирателей ${ }^{1}$.

Выборы имеют ярко выраженную властную природу, поскольку они обеспечивают воспроизводство публичной власти. В последние годы наметились тенденции превращения выборов в контролируемые каналы прихода к власти, когда при прочих равных условиях приоритет отдается представителям политических партий, обладающим мощным административно-финансовым ресурсом. В борьбе за доверие народа, за право от его имени осуществлять государственную власть, реальное соперничество отсутствует. Вместе с тем, как справедливо отмечают Ю.А. Веденеев и В.И. Лысенко, «значение периодически проводимых выборов и связанных с ними юридических гарантий прав и свобод в том и состоит, чтобы блокировать любые проявления монополии на власть, какими благими намерениями ни руководствовались при этом» ${ }^{2}$.

Современные исследователи указывают на то, что выборы могут выступать в качестве одного из важнейших способов легитимации государственной власти ${ }^{3}$. Для этого политической партии (кандидату) необходимо получить поддержку большинства избирателей и оправдывать своей деятельностью на выборных постах представление граждан о том, что органы государственной власти и

1 См. Федеральный закон от 12 июля 2006 г. № 107-Ф3 «О внесении изменений в отдельные законодательные акты Российской Федерации в части отмены формы голосования против всех кандидатов (против всех списков кандидатов); Федеральный закон от 5 декабря 2006 г. № 225-Ф3 «О внесении изменений в Федеральный закон «Об основных гарантиях избирательных прав и права на участие в референдуме граждан Российской Федерации» и Гражданский Процессуальный Кодекс Российской Федерации».

2 См.: Веденеев Ю.А., Лысенко В.И. Политика и федеральные выборы (К вопросу о взаимоотношениях между властью и правом) // Государство и право. 1995. № 2. С. 83.

${ }^{3}$ См.: Воробьев Н.И., Никулин В.В. Избирательное право и избирательный процесс в Российской Федерации. Тамбов: Изд-во ТГТУ, 2005. С. 4; Склифус C.B. Выборы как один из основополагающих принципов легитимации государственной власти в Российской Федерации // Правовая политика и правовая жизнь. 2008. № 3. С. 77-81; Дамаскин О.B. Легитимация результатов избирательного процесса и формирования органов государственной власти в Российской Федерации // Современное право. 2008. № 2. С. 19-24. 
местного самоуправления образованы на справедливой основе. Избрание (переизбрание) депутатов и должностных лиц, которые своей деятельностью покровительствовали организованной преступности, нанесли ущерб экономике, способствовали росту социальной напряженности, дискредитирует государственную власть и разочаровывает население в демократических ценностях. Данный аспект выборов конкретизирует М.В. Баглай: «Выборы дают выход накопившемуся у известной части населения недовольству действиями властей, они открывают единственно возможный путь демократического разрешения противоречий в обществе, исключая физическое столкновение людей и путь навязывания большинству мнения меньшинства или отдельных политиков» ${ }^{1}$.

Выборы как показатель степени доверия к власти и средство политической активизации населения имеют важное значение для защиты конституционного строя. В условиях высокой социальной активности можно определить уровень радикализма и протестный потенциал граждан, своевременно выявить процессы антиконституционной направленности, заблаговременно прогнозировать и пресекать попытки их использования в интересах отдельных лиц, преступных групп, определенных иностранных государств и международных организаций. Период избирательной кампании является оптимальным временем для проведения информационно-аналитической работы, в том числе и в интересах защиты конституционного строя.

В качестве серьезной проблемы российской системы народовластия нужно рассматривать несоответствие отдельных элементов конституционно-правовой регламентации выборов потребностям демократического развития данного института в Российской Федерации. Так, общественно-полезное стремление укрепить политическую систему Российской Федерации и повысить роль партий в формировании органов государственной власти и органов местного самоуправления на практике осуществляется в ущерб самой идее народовластия, многопартийности и политического плюрализма. Ликвидация избирательных

\footnotetext{
${ }^{1}$ См.: Баглай М.В. Конституционное право Российской Федерации. М.: Норма, 2006. С. 389.
} 
блоков, повышение заградительного барьера на выборах в Государственную Думу Федерального Собрания Российской Федерации до 7\%, освобождение от сбора подписей избирателей политических партий, федеральные списки кандидатов которых допущены к распределению депутатских мандатов на предшествующих выборах, закрепляют в Государственной Думе Федерального Собрания Российской Федерации и законодательных органах государственной власти субъектов Российской Федерации доминирующее положение правящих партий, стимулируют не только усиление роли партий в механизме формирования органов власти, но и процессы лоббирования партиями своих корпоративных интересов, сращивание партийного и государственного аппаратов, распространение партийной коррупции. При отсутствии устойчивых взаимосвязей с другими элементами гражданского общества партии становятся самодостаточными изолированными институтами российской политической системы, оторванными от рядовых граждан и реальных потребностей населения.

Ученые-юристы отмечают возможность возникновения «диктатуры партии большинства»: «Парламентское большинство, игнорируя мнение парламентского меньшинства, может полностью устранить это меньшинство от принятия скольконибудь значимых решений и полноценной парламентской деятельности, самовольно ограничить право на свободу слова для политических партий, пребывающих в оппозиции, проведение ими митингов и шествий, на равные условия в избирательном процессе... Отражая интересы господствующей партии или лоббистских групп, опираясь на принцип «свободы мандата», парламентарии могут принимать законы, не сообразовывая их с волей, желаниями и интересами избирателей, игнорируя или искажая их конституционные права и свободы» ${ }^{1}$. Такая законодательная политика снижает общую положительную направленность правового регулирования избирательного процесса в Российской Федерации и может привести к негативным социально-политическим результатам.

\footnotetext{
1 См.: Петренко Д.С. Судебный конституционный контроль как важнейший признак современного правового государства / Актуальные проблемы современного российского государствоведения. 2008. Вып. 1. / Под ред. С.Н. Бабурина М.: Изд-во РГТЭУ, 2008. С. 94, 98; Скосаренко Е.Е. Избирательная система России: мифы и политическая реальность. М.: Формула права, 2007. С. 101.
} 
Характеристика выборов в системе народовластия Российской Федерации может проявляться в стабилизирующей функции. Через выборы обеспечиваются стабильность и порядок в государственной и общественной жизни, если они позволяют гражданам выразить свою волю. По мнению М.В. Баглая, «смысл выборов не в том, чтобы продемонстрировать мнимый консенсус между всеми гражданами и социальными слоями, который никогда, кроме чрезвычайных ситуаций, не может быть достигнут в развитом обществе, а в том, чтобы все могли выразить свою волю, а государственная власть - быть созданной и действовать в соответствии с этой волей» ${ }^{1}$.

Выборы тесно связаны с существующей в государстве системой политических партий. Партии выступают инструментом организации избирательных кампаний и способствуют реализации народного представительства. Избиратели изучают программы политических партий, борющихся за власть, выбирают приемлемые для себя идеологические платформы и партийных кандидатов, выражающих их взгляды. Особенностью российских выборов является то, что они позволяют оценить главным образом не влияние политических партий и идеологических программ, а популярность отдельных кандидатов. Действующее избирательное законодательство допускает, а существующая электоральная практика в полной мере реализует возможность выдвижения политическими партиями популярных государственных и общественных деятелей во главе партийных списков. Эти лидеры «продвигают» в законодательные органы государственной власти основное количество кандидатов, представленных в партийных списках, а затем без каких-либо юридических последствий отказываются от полученных мандатов ${ }^{2}$. Размышляя об этой проблеме, Е.И. Колюшин предлагает два варианта ее решения: 1) закрепить передачу мандата другой партии при отказе от него лица, занимающего государственную или выборную муниципальную должность, или являющегося государственным или муниципальным служащим; 2) ввести запрет для данной

\footnotetext{
${ }^{1}$ См. Баглай М.В. Конституционное право Российской Федерации. М.: Норма, 2006. С. 389.

2 Представляется, что подобная практика должна быть законодательно ограничена, поскольку она может рассматриваться как разновидность введения избирателей в заблуждение. См. Приложение.
} 
категории лиц на отказ от депутатского мандата как минимум в течение года после избрания ${ }^{1}$.

Наконец, выборы являются опосредованной формой контроля граждан за деятельностью государственных и муниципальных органов ${ }^{2}$. Невзирая на то, что в современных условиях народные представители (депутаты и выборные должностные лица) зачастую весьма далеки от народа и, как правило, выражают интересы тех политических сил и финансово-промышленных групп, которые участвовали в финансировании их избирательных кампаний, именно выборы сегодня оставляют гражданам возможность участия в политической жизни и позволяют косвенно влиять на тех, в чьих руках находится власть.

Роль и место выборов в системе народовластия определяет их значение для обеспечения стабильности существующей политической системы России, воспроизводства и функционирования институтов власти, а также влияние на защиту конституционного строя.

Прежде чем исследовать значение выборов для защиты конституционного строя России, следует определиться с терминологическими категориями «конституционный строй», «государственный строй», «общественный строй», «основы конституционного строя», «безопасность государства», «государственная безопасность», «национальная безопасность», «обеспечение национальной безопасности», «охрана конституционного строя» и «защита конституционного строя».

Согласно Конституции России выборы - одна из основ конституционного строя Российской Федерации.

В нормативных правовых актах отсутствует определение конституционного строя, есть лишь упоминания о нем в качестве объекта защиты или посягательства на него.

В юридической литературе понятие «конституционный строй» рассматривается в широком и узком смыслах. В широком смысле конституционный строй

\footnotetext{
${ }^{1}$ См.: Колюшин Е.И. Концепция модернизации избирательного и связанного с ним законодательства // Вестник Московского ун-та. 2010. № 1. С. 75.

${ }^{2}$ См.: Дмитриев Ю.А., Исраелян В.Б. Избирательное право и процесс в Российской Федерации. Ростов-наДону: Феникс, 2004. С. 265.
} 
отождествляется с совокупностью экономических, социальных, политических, правовых, идеологических отношений, регулируемых нормами конституции и возникающих по поводу организации центральных органов государственной власти и управления, государственного устройства и правовых связей между личностью, обществом и государством. В узком смысле конституционный строй означает способ организации государства, закрепленный в конституции ${ }^{1}$.

Сторонниками широкого понимания конституционного строя являются Ю.П. Еременко, В.Т. Кабышев, О.Г. Румянцев².

Ю.П. Еременко понимает конституционный строй как «систему господствующих экономических, политических, идеологических отношений в их конституционной форме выражения, которые воплощают полновластие (суверенитет) народа и определяют сущность, основные черты общества в целом» ${ }^{3}$.

В.Т. Кабышев определяет конституционный строй как «систему конституционных отношений, а также конституционные нормы и принципы, регулирующие и закрепляющие отдельные виды общественных отношений существующего реального строя» ${ }^{4}$.

По мнению О.Г. Румянцева, конституционный строй представляет собой «совокупность социальных отношений» 5 .

Понятие конституционного строя в широком смысле дается и в Большом юридическом энциклопедическом словаре: «конституционный строй представленная в соответствующих структурах государства и общества и их институтов и закрепленная нормами Основного закона и другими

\footnotetext{
${ }^{1}$ См.: Козлова Е.И., Кутафин О.Е. Конституционное право России. М., 2006. С. 94 - 100.

${ }^{2}$ См.: Еременко Ю.П. Советская конституция и законность. Саратов, 1982. С. 18; Кабышев В.Т. Становление конституционного строя России. Саратов, 1993. С. 4; Румянцев О.Г. Основы конституционного строя России. M.,1994. $285 \mathrm{c}$.

${ }^{3}$ См.: Еременко Ю.П. Советская конституция и законность / Под ред. Ржевского В.А. Саратов, 1982. С. 18

${ }^{4}$ См.: Кабышев B.T. Становление конституционного строя России / Конституционное развитие России. Саратов, 1993. С. 4

${ }^{5}$ См.: Румянщев О.Г. Основы конституционного строя России. М.,1994.
} 
конституционно-правовыми актами система основополагающих общественных отношений〉 ${ }^{1}$.

Недостатком широкой трактовки понятия «конституционный строй» является фактическое отождествление конституционного строя с общественным. Подобная точка зрения представляется спорной. Во-первых, общественный строй является общественно-политической, а не конституционно-правовой категорией. Во-вторых, понятие «общественный строй», если рассматривать его как «исторически конкретную систему общества, обусловленную определенным уровнем производства, распределения и обмена продуктов, характерными особенностями общественного сознания и традициями взаимодействия людей в разных сферах жизни и охраняемую государством и правом» ${ }^{2}$, включает в себя широкий спектр социальных явлений (формы общественного сознания, социальные институты, социальные нормы), в том числе не регулируемых конституционным правом. С учетом сделанных оговорок, в монографии понятие «конституционный строй» рассматривается в узком смысле.

В ряде случаев конституционный строй ошибочно отождествляется с элементами общественного и государственного строя. Так, по мнению Л.В. Бутько, конституционный строй следует рассматривать как «закрепление в Конституции главных признаков и элементов общественного и государственного строя»³.

Как представляется, соотношение понятий «конституционный строй», «общественный строй» и «государственный строй» выглядит следующим образом. Государственный строй является частью общественного строя. При этом не всякий государственный строй может быть охарактеризован как конституционный. Подобная позиция нашла отражение в работах В.А. Лихобабина, А.Г. Пархоменко, Н.А. Ткачевой. По мнению В.А. Лихобабина и А.Г. Пархоменко, в отличие от государственного строя, «конституционный строй всегда предполагает наличие конституции. Кроме того, необходимыми признаками конституционного строя

\footnotetext{
C. 253 .

${ }^{1}$ См. Большой юридический энциклопедический словарь / Под ред. А.Б. Барихина. М.: Книжный мир, 2005. C. 381 .

2 См. Большой юридический энциклопедический словарь / Под ред. А.Б. Барихина. М.: Книжный мир, 2005.

${ }^{3}$ См.: Бутько Л.В. Конституция и конституционная реформа. М., 1998. С. 72.
} 
являются народный суверенитет, разделение властей, нерушимость и неотчуждаемость общепризнанных прав и свобод человека. Государственный строй может и не содержать этих признаков» ${ }^{1}$.

М.В. Баглай и Б.Н. Габричидзе также акцентируют внимание на категории прав и свобод человека и гражданина. Конституционный строй определяется ими как «порядок, при котором соблюдаются права и свободы человека и гражданина, а государство действует в соответствии с Конституцией» ${ }^{2}$. В формате данного подхода следует рассматривать и определение конституционного строя, сформулированное Н.А. Богдановой, которая понимает конституционный строй как «логическое построение, отражающее объективированное в нормах конституционного права устройство государства и общества, а также положение человека в системе отношений: государство-общество-личность» ${ }^{3}$.

Как справедливо отмечает Н.А. Ткачева, «далеко не всякий государственный строй является конституционным, но лишь такой, который адекватно отражает конституционные идеи и принципы, выражает определенный уровень политического развития, является результатом признания неотъемлемых прав человека, равного права для всех» ${ }^{4}$.

Рассматривая сущность конституционного строя, Н.А. Боброва выделяет его революционно-демократическую и консервативную стороны. По мнению ученого, «революционно-демократическая сущность конституционного строя выражается в том, что конституционный строй является продуктом революционного изменения механизма властвования. Но когда этот результат достигается, возникает иная цель защита конституционного строя. Революционная сторона конституционного строя уходит в прошлое. На передний план выдвигается цель сохранения и укрепления

${ }^{1}$ См.: Лихобабин В.А., Пархоменко А.Г. Российский конституционализм: теория, история, перспективы. М., 2000. C. $10-11$.

${ }^{2}$ См.: Баглай М.В., Габричидзе Б.Н. Конституционное право Российской Федерации. М., 1996. С. 96; Баглай M.B. Конституционное право Российской Федерации. М., 2001. С. 98.

${ }^{3}$ См.: Богданова Н.А. Система науки конституционного права. М., 2001. С. 161.

${ }^{4}$ См.: Ткачева Н.А. Проблемы гарантированности основ конституционного строя. Дис. ... канд. юрид. наук. Ставрополь, 2004. С. 76. 
конституционного строя, создания условий его стабилизации» ${ }^{1}$. Н.А. Боброва предлагает различать формальный и реальный конституционный строй: «конституционный строй означает, что народ признается (формальный) и является (реальный конституционный строй) источником всей государственной власти, участвуя в ее учреждении, формировании и функционировании в виде прямой и представительной демократии с гарантированием монополии народа и представительного органа на законодательную деятельность. Граница между формальным и реальным конституционным строем проходит через коренные интересы народа, критерием которых является его благосостояние, духовное и физическое здоровье, признание предельно допустимого уровня социального расслоения〉 $^{2}$.

Несмотря на то, что народовластие является идеальной теоретической конструкцией, образцом для подражания в развитии общества и государства, привязка содержания конституционного строя к механизму властвования народа заслуживает поддержки. В то же время ценностные и социологические критерии разграничения реального и формального аспектов конституционного строя требуют, как представляется, дополнительной аргументации.

Для того, чтобы четко представлять сущность конституционного строя, в нем необходимо выделить основополагающие начала, главные устои. Их принято называть основами конституционного строя³

В словаре С.И. Ожегова понятие «основа» рассматривается как «источник, главное, на чем строится что-нибудь, что является сущностью чего-нибудь» ${ }^{4}$.

Термин «основы конституционного строя» часто формулируется через

1 См.: Боброва Н.А. Конституционный строй и конституционализм в России (проблемы методологии, теории, практики). Автореф. дис. ... д-ра юрид. наук. М., 2004. С. 5.

${ }^{2}$ См.: Боброва Н.А. Указ. соч. С. 17.

${ }^{3}$ См.: Козлова Е.И., Кутафин О.Е. Конституционное право России. М., 2006. С. 94 - 100; Кутафин O.E. Государственное право Российской Федерации. Т. 1. М., 1993. С. 117; Мамонов В.В. Конституционный строй Российской Федерации: понятие, основы, гарантии // Государство и право. 2004. № 10. С. 5; Румянщев О.Г. Основы конституционного строя России. М., 1994. 285 с.

${ }^{4}$ См. Ожегов С.И. Словарь русского языка. М., 1964. С. 451. 
категорию принципов ${ }^{1}$. В Большом юридическом энциклопедическом словаре дается следующее определение: «основы конституционного строя - находящаяся под защитой государства система принципов, определяющих и регламентирующих общественные отношения, являющиеся объектом конституционно-правового регулирования; общие основополагающие начала конституционно-правовой регламентации конституционного строя»².

И.Н. Гальвина определяет основы конституционного строя как систему нормпринципов, выражающих основные черты государственного и общественного строя ${ }^{3}$

H.В. Бутусова и Н.А. Ткачева предлагают рассматривать основы конституционного строя в двух значениях: как совокупность общественных отношений, составляющих основы построения общества и государства, и как правовой институт, регулирующий эти отношения ${ }^{4}$. В первом значении под основами конституционного строя понимаются главные, ключевые общественные отношения, составляющие суть конституционного строя и выражающие в концентрированной форме наиболее демократические его характеристики (принцип народного суверенитета, принцип разделения властей, признание и защита неотъемлемых прав и свобод человека и т.д.). Во втором значении под основами конституционного строя подразумеваются конституционные нормы, закрепляющие и гарантирующие социальную исполнимость принципов организации общества и государства. В дальнейшем, однако, Н.А. Ткачева пытается определить основы конституционного строя через его признаки (к которым, на самом деле, отнесены классификации основ): политические, публично-правовые и гуманитарные основы конституционного строя (демократическая, правовая, федеративная государственность; республиканская

\footnotetext{
${ }^{1}$ См. Конституция Российской Федерации: Энциклопедический словарь / Под ред. В.А. Туманова, В.Е. Чиркина, Ю.А. Юдина. М., 1997; Большой юридический энциклопедический словарь. М., 2005. С. 410; Гальвина И.Н. Охрана и защита конституционного строя Российской Федерации. Автореф. дис. ... канд. юрид. наук. Челябинск, 2006. С. 8; Новинский В.В. Основы конституционного строя как система конституционных принципов // Российский юридический журнал. 2004. № 1. С. 9-15.

${ }^{2}$ См.: Большой юридический энциклопедический словарь словарь / Под ред. А.Б. Барихина. М.: Книжный мир, 2005. С. 410.

${ }^{3}$ См.: Гальвина И.Н. Охрана и защита конституционного строя Российской Федерации. Автореф. дис. ... канд. юрид. наук. Челябинск, 2006. С. 8. См. также Новинский B.B. Основы конституционного строя как система конституционных принципов // Российский юридический журнал. 2004. № 1. С. 9-15.

${ }^{4}$ См.: Бутусова Н.В. Основы конституционного строя Российской Федерации как правовой институт и предмет конституционно-правового регулирования // Вестник Московского университета. 2003. №6. С. 17-29; Ткачева Н.A. Проблемы гарантированности основ конституционного строя. Дис. ... канд. юрид. наук. Ставрополь, 2004. C. 83.
} 
форма правления; признание человека, его прав и свобод высшей ценностью; приоритет народного суверенитета над государственным; принцип разделения властей; признание и гарантирование местного самоуправления); социальные основы конституционного строя (социальный характер российского государства); экономические основы конституционного строя (принципы рыночной экономики; признание многообразия форм собственности); духовно-нравственные и идейные основы конституционного строя (светский характер государственности; принципы идеологического и политического многообразия); юридические основы конституционного строя (верховенства Конституции Российской Федерации и законов $)^{1}$. Такая позиция, на наш взгляд, является ошибочной, поскольку понятие основ конституционного строя предполагает выделение их наиболее важных признаков, в то время как классификация основ конституционного строя означает их группировку на определенные классы.

Перечень основ конституционного строя находит свое выражение в главе 1 Конституции Российской Федерации. Можно сгруппировать их как целостную систему.

Е.И. Козлова и О.Е. Кутафин различают политические, экономические, социальные и духовные основы конституционного строя ${ }^{2}$ К Критерием данной классификации является сфера общественной жизни, в которой возникают соответствующие конституционно-правовые отношения. Такой подход к научной классификации раскрывает сущность основ конституционного строя, но не учитывает характер конституционно-правового регулирования отношений между человеком, обществом и государством.

А.В. Малько, Е.В. Колесников и Г.Н. Комкова выделяют базовые ценности общества, основные принципы и конституционно-правовые институты и нормы, через которые эти ценности и принципы получают непосредственное обоснование и

\footnotetext{
${ }^{1}$ См.: Ткачева Н.А. Проблемы гарантированности основ конституционного строя. Дис. ... канд. юрид. наук. Ставрополь, 2004. С. 78.

${ }^{2}$ См.: Козлова Е.И., Кутафин О.Е. Указ. соч. С. $94-100$.
} 
закрепление ${ }^{1}$ У Казанная классификация основ конституционного строя заслуживает внимания, однако отличается нечеткостью оснований деления.

И.Н. Гальвина предлагает классифицировать основы конституционного строя в соответствии с направленностью правовой регламентации конституционных норм принципов на следующие группы: закрепляющие народовластие; определяющие основы конституционно-правового статуса человека и гражданина; регламентирующие основные характеристики государства и органов публичной власти; устанавливающие политические основы конституционного строя; определяющие экономические основы конституционного строя; регламентирующие принципы конституционно-правового регулирования и гарантии основ конституционного строя ${ }^{2}$.

Более удачной представляется классификация, предложенная М.Б. Рожковым³. Она основана на принципах конституционно-правового регулирования отношений между человеком, обществом и государством, которые служат четким основанием классификации.

К первой группе основ конституционного строя он отнес основы организации государственной власти: народовластие (высшим непосредственным выражением которого являются свободные выборы и референдум (статья 3 Конституции); федерализм (статья 5 Конституции); верховенство права (статья 4 Конституции); принцип разделения властей (статья 10 Конституции); государственный суверенитет (статья 4 Конституции).

Вторую группу составляют основы взаимоотношений государства и человека, гражданина, правового статуса человека и гражданина. К ним относятся: признание и утверждение прав и свобод человека и гражданина высшей ценностью; их защита и соблюдение - обязанностью государства (статья 2 Конституции).

Третья группа включает основы организации жизни общества:

\footnotetext{
${ }^{1}$ См.: Малько А.В., Колесников Е.В., Комкова Г.Н. Конституционное право России. М., 2001. 408 с.

${ }^{2}$ См.: Гальвина И.Н. Охрана и защита конституционного строя Российской Федерации. Автореф. дис. ... канд. юрид. наук. Челябинск, 2006. С. 8.

3 См.: Рожков М.Б. Объект безопасности государства: конституционный строй или основы конституционного строя // В мире права. 2000. № 2. С. 34-41.
} 
идеологический и политический плюрализм (статья 13 Конституции); светский характер государства (статья 14 Конституции); свободу экономической деятельности (статья 8 Конституции); многообразие и равноправие различных форм собственности (статья 8 Конституции); социальный характер государства (статья 7 Конституции).

Установленные Конституцией Российской Федерации основы конституционного строя обладают рядом специфических черт, к числу которых относят: их фундаментальное значение; политико-правовой характер; нормативность; юридическое верховенство по отношению ко всем остальным положениям конституции и других нормативных правовых актов; общепризнанность; целостность; устойчивость; особый порядок изменения.

В соответствии со статьей 1 Закона Российской Федерации «О безопасности» конституционный строй является объектом безопасности государства.

Понятие «безопасность государства» означает определенное состояние общественных отношений, обеспечивающее политическое господство правящей социальной группе (классу) внутри государства и за его пределами.

Государственная безопасность предполагает способность государства противостоять внутренним и внешним посягательствам на его суверенитет, территориальную целостность, конституционный строй.

С учетом данного подхода попытки отождествления понятий «безопасность государства» и «государственная безопасность» представляются ошибочными, поскольку безопасность государственного аппарата и его чиновников не сопоставимы с незыблемостью конституционного строя, территориальной целостностью, военной мощью и суверенитетом государства. Более того, устойчивость функционирования и стабильность воспроизводства государственного аппарата могут сопровождаться подрывом конституционного строя, снижением военного потенциала и ограничением суверенитета государства. Более правильным было бы рассматривать конституционный строй в качестве объекта национальной безопасности, а не безопасности государства. 
В Концепции национальной безопасности под национальной безопасностью Российской Федерации понималась безопасность ее многонационального народа как носителя суверенитета и единственного источника власти в Российской Федерации ${ }^{1}$ В Стратегии национальной безопасности Российской Федерации до 2020 года понятие «национальная безопасность» раскрывается как состояние защищенности личности, общества и государства от внутренних и внешних угроз, которое позволяет обеспечить конституционные права, свободы, достойные качество и уровень жизни граждан, суверенитет, территориальную целостность и устойчивое развитие Российской Федерации, оборону и безопасность государства ${ }^{2}$.

Российская политико-правовая доктрина связывает понятие «защита конституционного строя» с понятием «обеспечение национальной безопасности».

Согласно Стратегии национальной безопасности Российской Федерации обеспечение национальной безопасности представляет собой целенаправленную деятельность государственных институтов по выявлению, предупреждению и пресечению различных угроз безопасности личности, обществу и государству, защите национальных интересов Российской Федерации. Стратегическими целями обеспечения национальной безопасности в условиях выборов являются защита основ конституционного строя Российской Федерации, основных прав и свобод человека и гражданина, охрана суверенитета Российской Федерации, ее независимости и территориальной целостности, а также сохранение гражданского мира, политической и социальной стабильности в обществе.

Защиту конституционного строя России следует рассматривать как направление обеспечения национальной безопасности, включающее в себя защиту основных прав и свобод человека и гражданина, обеспечение народовластия, верховенства и прямого действия Конституции на всей территории государства, территориальной целостности и суверенитета,

\footnotetext{
${ }^{1}$ См. Указ и.о. Президента Российской Федерации от 10 января 2000 г. №24 «О Концепции национальной безопасности Российской Федерации». [Утратил силу].

2 См. Указ Президента Российской Федерации от 12 мая 2009 г. № 537 «Об утверждении Стратегии национальной безопасности Российской Федерации до 2020 года» // Рос. газ. 2009. 19 мая.
} 
поощрение политического и идеологического плюрализма, развитие конституционного контроля за выборными и назначаемыми государственными и муниципальными органами, а также привлечение к юридической ответственности за нарушение конституционных норм. Такая позиция представляет собой демократический подход к пониманию защиты конституционного строя.

В случае, если правящая социальная группа (класс) пытается отстранить народ от формирования государственной власти и контроля за ее деятельностью, ограничивает общедемократические права и свободы граждан, ликвидирует идеологическое и политическое многообразие, многопартийность, устраняет оппозицию, отменяет конституционную форму правления и государственного устройства, защита конституционного строя сводится лишь к сохранению с помощью аппарата управления и принуждения экономического, политического и идеологического господства правящей социальной группы (класса). Данный подход к защите конституционного строя можно охарактеризовать как антидемократический. Носители подобного антидемократического подхода к защите конституционного строя имеют нигилистическое правосознание, не одобряют ценности конституционно-правовых институтов и норм, руководствуются групповыми и личными интересами.

В юридической литературе принято различать понятия «охрана конституционного строя» и «защита конституционного строя». Критериями дифференциации данных понятий выступают субъекты и характер соответствующих мер.

Так, И.Н. Гальвина под охраной конституционного строя понимает «деятельность государственных органов, органов местного самоуправления, общественных объединений и отдельных индивидов по обеспечению реализации конституционных норм-принципов ${ }^{1}{ }^{2}$ В качестве защиты конституционного строя автор определяет «обеспечиваемый государственными органами механизм принудительной реализации конституционных норм соответствующими

${ }^{1}$ См.: Гальвина И.Н. Охрана и защита конституционного строя Российской Федерации. Автореф. дис. ... канд. юрид. наук. Челябинск, 2006. С. 15. 
способами и средствами» ${ }^{1}$. Г.С. Решетникова справедливо отмечает, что «охрана конституции тем или иным образом осуществляется всеми субъектами конституционного права. Защищать же конституцию могут только государственные органы» ${ }^{2}$.

Другие ученые, рассматривая правовую охрану конституционного строя, акцентируют внимание на мерах предупредительного, профилактического характера. По мнению В.Н. Бутылина, В.А. Виноградова, Э.Е. Втулкиной и Н.М. Колосовой, «охрана конституции направлена на предупреждение нарушений конституционных норм», в то время как защита конституционного строя «состоит в устранении нарушений этих норм»³ ${ }^{3}$ Данную позицию поддерживает М.П. Авдеенкова, Ю.А. Дмитриев, Т.И. Ряховская ${ }^{4}$.

Следует согласиться с дифференциацией данных понятий и в избирательном процессе. Представляется, что кандидаты на выборные должности, их доверенные лица, наблюдатели, объединения избирателей способствуют реализации и предупреждению нарушений конституционных норм в избирательном процессе, но субъектами защиты конституционного строя в избирательном процессе не являются, поскольку не обладают соответствующими правомочиями, материальными ресурсами, правом издавать нормативные правовые и правоприменительные акты, легальной возможностью осуществлять меры принудительного характера.

Часть ученых-юристов рассматривает правовую охрану конституции в широком и узком смыслах. Охрана конституции в широком смысле предполагает

\footnotetext{
${ }^{1}$ См.: Гальвина И.Н. Указ. соч. С. 16.

${ }^{2}$ См.: Решетникова Г.С. Защита (охрана) Конституции Российской Федерации 1993 года // Норма. Закон. Законодательство. Право: Тезисы докладов межвузовской научно-практической конференции. Пермь.: изд-во Перм. гос. ун-та, 2006. Ч. 2. С. 27-29.

${ }^{3}$ См.: Бутылин В.Н. Институт государственно-правовой охраны конституционных прав и свобод граждан // Право и власть. 2002. № 2. С. 37; Виноградов В.А. Проблемы охраны (защиты) Конституции Российской Федерации и конституционно-правовая ответственность // Конституционное и муниципальное право. 2003. № 1. С. 2; Втулкина Э.E. Проблема охраны (защиты) Конституции Российской Федерации и конституционно-правовая ответственность субъектов Федерации: вопросы теории и проблемы реализации // Проблемы понимания и тенденции развития государства и права в XXI веке. Сб. науч. трудов. Ставрополь, 2004. С. 92; Конституционное законодательство России. М.: Городец, 1999. С. 374.

${ }^{4}$ См.: Авдеенкова М.П., Дмитриев Ю.А. Конституционное право Российской Федерации: Основы теории конституционного права. Ч.1. М., 2002. С. 205-206; Ряховская Т.И. К вопросу о соотношении понятий правовая охрана и защита Конституции Российской Федерации // Проблемы государства, права, культуры и образования в современном мире: материалы VI Международной научно-практической Интернет-конференции. Тамбов: Издат. дом ТГУ, 2009. С. 139-144.
} 
создание необходимых условий, развитие соответствующих гарантий, совершенствование государственно-правовых средств и методов обеспечения действия конституционных норм ${ }^{1}$. В узком смысле под охраной конституции понимается совокупность контрольно-надзорных полномочий и мер, осуществляемых государственными органами, правомочными проверять содержание нормативных актов и действий адресатов права на предмет их соответствия Основному закону страны ${ }^{2}$.

На наш взгляд, понятие правовой охраны конституции в широком смысле более точно отражает сущность обеспечения реального функционирования конституции.

Применительно к теоретическим исследованиям защиты конституционного строя необходимо отметить позицию О.Н. Дорониной, Д.С. Коровинских и О.Е. Кутафина, согласно которой защита конституционного строя может рассматриваться как специфическая правоохранительная деятельность государства, направленная на защиту норм конституции и применение мер государственного принуждения в случае их нарушения ${ }^{3}$. Выделение государства в лице его компетентных органов в качестве субъекта осуществления особого вида деятельности по защите конституционного строя представляется правильным.

Анализ понятийно-категориального аппарата в рассматриваемой предметной области подразумевает также изучение конструкций «национальные интересы» и «интересы защиты конституционного строя» ${ }^{4}$

Государственная политика защиты конституционного строя в условиях выборов определяется национальными интересами Российской Федерации.

\footnotetext{
1 См.: Хабриева Т.Я. Правовая охрана конституции. Казань, 1995. С. 15. См. также Ведерников Н.T., Петренко Д.С. Конституционное правосудие (исторические, теоретические и организационные основы): Монография. М.: изд-во РГТЭУ, 2009. С. 11-12.

${ }^{2}$ См. Конституционное право / Отв. ред. А.Е. Козлов. М., 1996. С. 401.

${ }^{3}$ См.: Доронина О.Н., Коровинских Д.С. Система правовой охраны Конституции Российской Федерации // Государственная власть и местное самоуправление. 2005. № 5. С. 3; Кутафин О.Е. Предмет конституционного права. М.: Юрист, 2001. С. 120.

${ }^{4}$ По данному вопросу см. Хабриева Т.Я. Национальные интересы и законодательные приоритеты России // Журнал российского права. 2005. № 12. С. 19-29; Хабриева Т.Я. Национальные интересы и российское законодательство // Право и безопасность. 2005. № 4. С. 71-79; Мальцеев В.А. Влияние категории «интерес» на конституционно-правовые отношения в сфере обеспечения безопасности // Конституционное и муниципальное право. 2005. № 6. С. 26.
} 
В Стратегии национальной безопасности Российской Федерации до 2020 года национальные интересы Российской Федерации рассматриваются как совокупность внутренних и внешних потребностей государства в обеспечении защищенности и устойчивого развития личности, общества и государства.

Интересы защиты конституционного строя Российской Федерации в избирательном процессе являются системообразующим элементом национальных интересов России. С одной стороны, они направлены на развитие демократии и гражданского общества; с другой стороны, призваны обеспечить незыблемость конституционного строя, территориальной целостности и суверенитета Российской Федерации.

В группу интересов по развитию демократии и гражданского общества в Российской Федерации входят: повышение политической активности и правовой культуры граждан; развитие политического плюрализма; недопущение узурпации государственной власти одним политическим деятелем (одной политической партией); формирование и осуществление политики органов народного представительства с учетом общественного мнения; развитие общественного контроля избирательного процесса; защита политических (в том числе избирательных) прав граждан.

Среди интересов, направленных на обеспечение незыблемости конституционного строя, территориальной целостности и суверенитета Российской Федерации, следует выделить: сохранение политической стабильности в обществе; противодействие коррупции, сепаратизму, экстремизму и терроризму в условиях выборов; противодействие криминализации органов государственной власти и органов местного самоуправления; обеспечение легитимности формирования органов государственной власти и органов местного самоуправления; недопущение дезорганизации нормального функционирования органов государственной власти и органов местного самоуправления; недопущение массовых нарушений избирательных прав граждан и иных участников избирательного процесса; обеспечение политической независимости государства в условиях агрессивного иностранного (международного) 
наблюдения за выборами; недопущение использования избирательных кампаний в качестве механизмов захвата политической власти ставленниками иностранных государств и финансируемых ими организаций.

Эффективная защита конституционного строя невозможна без реализации интересов защиты конституционного строя в рамках регулирования подготовки и проведения выборов. Правовая регламентация избирательного процесса, выстроенная на основе системы интересов защиты конституционного строя, и адекватная ей правореализация позволяют обеспечить безопасность выборов как объекта защиты конституционного строя в сфере организации и функционирования государственной власти.

Выборы обеспечивают преемственность и периодичность воспроизводства публичной власти в России. Тем самым их проведение выступает гарантом стабильности институтов государственной власти и местного самоуправления и, в конечном счете, влияет на защиту конституционного строя. Приход к власти представителей тех или иных политических сил с помощью выборов обусловливает определенное состояние защищенности конституционного строя. От решений, принимаемых органами народного представительства и выборными лицами, зависит степень реализации конституционных прав и свобод граждан, характер средств и методов осуществления государственной власти.

Выборы выступают альтернативой силовому сценарию завоевания государственной власти. Как правило, с их помощью мирно разрешаются существующие в обществе противоречия и локализуется недовольство определенной части граждан.

Устойчивость развития политической системы, основанной на выборности народных представителей, разделении властей, демократических средствах и методах властвования, и ее защищенность от внутренних и внешних негативных воздействий зависят от способности законодательства и правоприменительной практики противодействовать угрозам, возникающим в условиях выборов, и удовлетворять возрастающие потребности в защите конституционного строя. Поэтому большого внимания заслуживает изучение объектов защиты, источников 
посягательств и комплекса угроз, которые могут возникать в ходе избирательных кампаний.

Таким образом, деятельность государства по защите конституционного строя в избирательном процессе представлена двумя уровнями. Первый уровень защиты конституционного строя предполагает реализацию интересов защиты конституционного строя в рамках регулирования избирательного процесса. Второй уровень защиты конституционного строя включает обеспечение соответствующих объектов защиты в формате правоприменительной и юрисдикционной деятельности государства. Указанные уровни защиты конституционного строя неразрывно связаны и взаимно дополняют друг друга.

Объекты защиты конституционного строя в условиях выборов характеризуются разнообразием. К ним можно отнести:

политико-правовые основы организации государства (демократизм, государственный суверенитет, конституционная форма правления и государственного устройства, верховенство права);

идеологические основы общества (политический и идеологический плюрализм, светский характер государства);

социальные основы общества (общественно-политическая стабильность, гражданский мир, защищенность и безопасность граждан, конституционные права и свободы);

институты политической системы и конституционный порядок их организации и деятельности (выборные органы государственной власти и органы местного самоуправления, конституционный порядок организации и деятельности политических партий, общественных объединений, средств массовой информации).

По направленности воздействия объектами защиты являются: руководители и специалисты избирательных комиссий, кандидаты и их доверенные лица, уполномоченные представители кандидатов и политических партий по финансовым вопросам, судьи и прокуроры, рассматривающие избирательные споры, наблюдатели (иностранные и международные наблюдатели), представители средств 
массовой информации, избиратели. В качестве материально-технических объектов защиты могут выступать: помещения, транспорт, средства связи, избирательная документация, программно-технические средства, подсистемы связи и передачи данных, информационные ресурсы избирательных комиссий (ГАС «Выборы» и ее фрагменты), помещения общественных приемных и избирательных штабов кандидатов, политических партий, здания и сооружения, предназначенные для проведения агитационных мероприятий, места массового скопления избирателей.

Источники посягательств в избирательном процессе представляется возможным подразделить на две основные группы: внутренние и внешние источники посягательств.

Внутренними источниками посягательств в избирательном процессе являются отдельные должностные лица, принимающие участие в разработке и принятии нормативных правовых актов, противоречащих Конституции и федеральным законам (в том числе, о выборах), не исполняющие судебные решения о приведении в соответствие федеральному законодательству указанных нормативных правовых актов; коррумпированные должностные лица избирательных комиссий, госслужащие и сотрудники правоохранительных органов, оказывающие содействие в организации и проведении выборов; преступные группы, стремящиеся к продвижению своих кандидатов на выборные должности в органы государственной власти и местного самоуправления; незаконные вооруженные формирования и организации, осуществляющие террористическую деятельность на территории России; действующие в Российской Федерации общественные и религиозные объединения, СМИ, а также отдельные лица, ставящие целью подготовку и осуществление экстремистской деятельности в условиях выборов.

Внешними источниками посягательств в избирательном процессе выступают: отдельные иностранные государства, заинтересованные в ослаблении, изменении и подрыве конституционного строя Российской Федерации; спецслужбы и государственные организации некоторых иностранных государств, конспиративно инициирующие и активно поддерживающие деятельность «прозападных» партий, сепаратистских, национал-радикальных, экстремистских движений и организаций на территории России; иностранные некоммерческие 
организации, осуществляющие под видом гуманитарных программ поддержку экстремистским силам на территории России; зарубежные научноисследовательские структуры, разрабатывающие стратегию и тактику ослабления, изменения и подрыва конституционного строя России.

В зависимости от источника негативного воздействия угрозы конституционному строю, возникающие в ходе избирательных кампаний, представляется целесообразным классифицировать на внутренние и внешние.

На сегодняшний день можно условно выделить следующие внутренние угрозы, возникающие в избирательном процессе в Российской Федерации:

несовершенство избирательного законодательства, возникновение пробелов и (или) коллизий между федеральным и региональным законодательством о выборах в связи с постоянным изменением федеральной нормативной правовой базы, регулирующей организацию и проведение выборов;

попытки продвижения российскими организованными преступными группами своих кандидатов в органы государственной власти и местного самоуправления ${ }^{1}$;

практика выдвижения избирательными объединениями в ряде субъектов Российской Федерации кандидатов по национальным, религиозным, родственным и клановым признакам;

противоправные посягательства участников избирательного процесса и иных лиц, направленные на подготовку и совершение террористических и иных экстремистских действий в процессе организации и проведения выборов;

использование технологий манипулятивного воздействия на общественное сознание;

нарушение порядка финансового обеспечения подготовки и проведения выборов; злоупотребления в формировании и использовании избирательных фондов; коррумпированность избранных с помощью нелегальных финансовых

1 Здесь и далее под организованной преступной группой понимается устойчивая и сплоченная преступная организация, имеющая иерархическую структуру, сферу преступного влияния и созданная для совершения тяжких или особо тяжких преступлений. Организаторы, руководители (лидеры) или иные представители организованной преступной группы определяются как криминалитет. 
средств выборных должностных лиц и депутатов представительных органов государственной власти и местного самоуправления;

подкуп избирателей;

организационная, материальная, финансовая и техническая зависимость избирательных комиссий, судов и территориальных подразделений федеральных органов исполнительной власти (в том числе правоохранительных органов) от федеральных должностных лиц и высших должностных лиц субъектов Российской Федерации в процессе организации и проведения выборов;

злоупотребление и (или) ненадлежащее осуществление властных полномочий госслужащими и должностными лицами, обеспечивающими организацию и проведение выборов;

попытки фальсификации должностными лицами избирательных комиссий итогов голосования и результатов выборов ${ }^{1}$.

Внешние угрозы конституционному строю, возникающие в избирательном процессе, включают:

латентные попытки продвижения спецслужбами и организациями некоторых иностранных государств своих кандидатов в органы государственной власти и местного самоуправления Российской Федерации;

стремление ряда иностранных государств оказывать конспиративное целенаправленное информационно-пропагандистское, финансовое, политическое и силовое воздействие на избирательный процесс в ущерб конституционному строю России;

попытки использования спецслужбами и организациями ряда иностранных государств возможностей избирательного процесса для легального сбора и добывания информации в ущерб конституционному строю России;

использование отдельными иностранными государствами информационной зависимости России и дружественных ей государств от развитых стран Запада для

\footnotetext{
${ }^{1}$ При включении попыток фальсификации должностными лицами избирательных комиссий итогов голосования и результатов выборов в число угроз конституционному строю, которые могут возникать в ходе избирательных кампаний, автор руководствовался не масштабом распространения данных деяний в деятельности избирательных комиссий, а степенью вреда, который указанные фальсификации способны нанести авторитету системе избирательных комиссий и государственной власти Российской Федерации в целом.
} 
нанесения ущерба конституционному строю Российской Федерации, в том числе в ходе выборов.

В качестве самостоятельной группы угроз конституционному строю, в рамках которой источники негативного воздействия могут носить как внутренний, так и внешний характер, следует рассматривать угрозы информационной безопасности ГАС «Выборы», направленные на конституционные права и свободы граждан ${ }^{1}$.

Как уже говорилось выше, в качестве одной из внутренних угроз конституционному строю России выступает несовершенство избирательного законодательства, возникновение пробелов и (или) коллизий между федеральным и региональным законодательством о выборах в связи с постоянным изменением федеральной нормативной правовой базы, регулирующей организацию и проведение выборов.

На современном этапе противоречия между федеральным и региональным законодательством о выборах чаще всего обусловлены динамичным развитием федеральной нормативной правовой базы. Региональные законодатели не всегда способны оперативно реагировать на постоянные изменения федерального избирательного законодательства. Другой причиной появления временных коллизий и пробелов стало совершенствование государственного строительства Российской Федерации в связи с состоявшимися в ряде регионов референдумами по объединению в новые субъекты Российской Федерации ${ }^{2}$.

Постоянные изменения федерального законодательства о выборах отрицательно влияют на обеспечение единого правового пространства Российской Федерации и противоречат интересам укрепления российской государственности.

1 См. Концепция развития безопасности информации в Государственной автоматизированной системе Российской Федерации «Выборы» (одобрена Постановлением ЦИК России от 26 декабря 2005 г. № 163/1080-4); Вешняков A.A. Общая характеристика гарантий обеспечения избирательных прав граждан с использованием ГАС «Выборы» // Конституционное и муниципальное право. 2006. № 8. С. 2-9; Савин С.Ю. Правовое обеспечение информационной безопасности Государственной автоматизированной системы Российской Федерации «Выборы»: дис. ...кканд. юрид. наук / РАГС при Президенте РФ. М., 2007. С. 35-37.

21 января 2007 г. в результате объединения Красноярского края, Таймырского и Эвенкийского автономных округов был образован Красноярский край; 1 июля 2007 г. в результате объединения Камчатской области и Корякского автономного округа образован Камчатский край; 1 января 2008 г. в результате объединения Иркутской области и Усть-Ордынского Бурятского автономного округа образована Иркутская область; 1 марта 2008 г. в результате объединения Читинской области и Агинского Бурятского автономного округа образован Забайкальский край. 
В числе главных угроз конституционному строю России необходимо выделить попытки продвижения организованными преступными группами своих кандидатов в органы государственной власти и местного самоуправления. 25 февраля 2009 г., выступая на расширенном заседании Коллегии Генеральной прокуратуры Российской Федерации, Президент Российской Федерации Д.А. Медведев отметил, что на муниципальном уровне наблюдается довольно высокое представительство криминалитета. «Криминальные элементы, авторитеты и авторитетики местного масштаба не должны находиться в местных органах власти, а их там достаточное количество», - заявил глава государства ${ }^{1}$.

Развитие экономических отношений в Российской Федерации, проходившее в период заметного ослабления регулирующей роли государства в экономике, отсутствие необходимой нормативной базы рыночного хозяйствования, широкомасштабный раздел государственной собственности с использованием незаконных методов и средств привели к массовому вовлечению в экономические процессы представителей организованных преступных групп и постепенному установлению криминального контроля над значительным числом хозяйствующих субъектов. Заинтересованность преступных групп в постоянном наращивании своих доходов, прямая зависимость официальной и теневой экономической деятельности от политической конъюнктуры в Российской Федерации, желание обеспечить личную безопасность обусловили стремление лидеров криминалитета легализовать свой статус и принимать активное участие в принятии политических решений. Удобным каналом реализации указанных криминальных интересов стало участие организованных преступных групп в избирательных кампаниях, проходящих в Российской Федерации ${ }^{2}$.

В качестве угрозы конституционному строю необходимо рассматривать практику выдвижения избирательными объединениями в ряде субъектов

\footnotetext{
${ }^{1}$ Cм.: http://archive.kremlin.ru/text/news/2009/02/213299.shtml

${ }^{2}$ См.: Климова Ю.Н. Преступность и массовая коммуникация в период предвыборной агитации. Дис. ... канд. юрид. наук. Н.Новгород, 2003. 233 с; Горшенков Г.Г., Климова Ю.Н. Способы проникновения во власть организованной экономической преступности в условиях выборов / Обеспечение прав личности и интересов государства в современном обществе. Сб. тезисов Всерос. науч. - практ. конф. Муром, 2004. С. 211-217; Климова $Ю . Н$. Оценка эффективности системы антикриминальной безопасности избирательного процесса / Актуальные проблемы юридической науки и правоприменительной практики. Сб. науч. трудов. Вып. 5. Сыктывкар, 2008. С. $103-115$.
} 
Российской Федерации (Карачаево-Черкесская Республика, Республика Дагестан, Тульская область и др.) кандидатов по национальным, религиозным, родственным и клановым признакам. Подобные злоупотребления партийных функционеров разочаровывают население в демократических ценностях, ведут к протестным настроениям, вызывают недовольство других диаспор национально-кадровой политикой в субъекте Российской Федерации, стимулируют национальную, религиозную и социальную рознь.

Наряду с попытками монополизировать власть по национальным, родственным, клановым и другим признакам, внутренней угрозой стали участившиеся противоправные посягательства участников избирательного процесса и иных лиц, направленные на подготовку и совершение террористических и иных экстремистских действий в ходе избирательных кампаний.

Согласно информации Следственного комитета при Прокуратуре Российской Федерации тенденция к росту преступлений экстремистской направленности продолжает оставаться устойчивой. В частности, за январь - сентябрь 2008 г. в Российской Федерации зарегистрировано 380 преступлений данной категории, что на 62,4 \% больше, чем в 2007 г. По данным Генеральной прокуратуры Российской Федерации наибольшее количество преступлений за период 2007-2008 гг., связанных с экстремистскими проявлениями, совершено в Москве, СанктПетербурге, Республике Башкортостан, Республике Татарстан, Ставропольском крае, Свердловской, Кемеровской, Тюменской и Новосибирской областях. Наиболее высокие темпы прироста экстремистских преступлений в Центральном федеральном округе - 69,9 \% (73 - в 2006 г., 124 - в 2007 г.) и Сибирском федеральном округе 135\% (14 - в 2006 г., 33 - в 2007 г.) $)^{1}$. Актуальность противодействия экстремистской деятельности в условиях выборов подтверждается установками главы государства в адрес руководителей правоохранительных органов Российской Федерации в связи с подготовкой федеральных выборов 2007 - 2008 гг. Так, 9 марта 2007 г. на встрече в Кремле с высшими офицерами Президент Российской Федерации призвал органы

\footnotetext{
${ }^{1}$ См. Актуальные проблемы противодействия национальному и политическому экстремизму: Материалы Всероссийской научно-практической конференции. Т. 1. Махачкала: Изд-во Лотос, 2008. С. 14-15.
} 
федеральной службы безопасности не допустить использования в ходе избирательных кампаний лозунгов националистического и экстремистского характера ${ }^{1}$.

Выборы дают возможность обнародования политических программ и участия сепаратистских, национал-радикальных и экстремистских организаций в массовых мероприятиях, открытой пропаганды их идеологических взглядов. Выборные кампании широко освещаются в СМИ, поэтому любое противоправное посягательство, направленное на изменение или подрыв конституционного строя, поданное под прикрытием оппозиционной или радикальной политической деятельности, приобретает широкий общественный резонанс.

В ходе избирательного процесса проводятся общественно-политические и иные массовые агитационные мероприятия с привлечением значительной части населения. С учетом возрастания угрозы террористических акций особую актуальность приобретает обеспечение безопасности населения в местах массового скопления граждан при подготовке и в ходе избирательных кампаний.

Угрозой конституционному строю может выступать использование избирательных технологий манипулятивного воздействия на общественное сознание ${ }^{2}$. Манипулирование общественным сознанием осуществляется, главным образом, в следующих формах: распространение анонимных печатных агитационных материалов; использование изображений известных политических и общественных деятелей без их согласия; участие в предвыборной агитации лиц, которым ее проведение запрещено законом; нарушение установленного порядка организации (проведения) собраний, митингов, демонстраций, шествий или пикетирования. Среди выявленных в ходе избирательной кампании по выборам Президента Российской Федерации 2008 г. агитационных печатных материалов, распространяемых на территории субъектов Российской Федерации с нарушением требований избирательного законодательства: 65\% составляли материалы без выходных данных (Республика Мордовия, Пермский край, Приморский край,

\footnotetext{
${ }^{1}$ Cм.: http://archive.kremlin.ru/2007/03/09/1839_type 63376_119347.shtml

2 Думается, что по вопросу использования избирательных технологий манипулятивного воздействия на общественное сознание следует вести отдельное исследование. В монографии манипулятивное воздействие на общественное сознание рассматривается как скрытое психологическое принуждение, направленное на программирование целевых установок, поведения, мнений и психических состояний населения.
} 
Астраханская область, Иркутская область, Кировская область, Магаданская область, Нижегородская область, Орловская область, Ростовская область, Смоленская область, Тамбовская область, Тверская область, Ямало-Ненецкий автономный округ); 19\% - материалы, содержащие признаки экстремизма и социальной розни (Республика Мордовия, Пермский край, Приморский край, Астраханская, Магаданская, Кировская, Нижегородская, Ростовская, Смоленская области и Ямало-Ненецкий автономный округ); 6\% - материалы с изображением физических лиц без их согласия (Пермский край, Смоленская область); 6\% - материалы, не представленные в избирательные комиссии (Пермский край, Тюменская область); 4\% - материалы, изготовленные до начала избирательной кампании (Нижегородская область $)^{1}$.

Как показывает практика, характер внутренней угрозы конституционному строю России приобретают финансовые злоупотребления при формировании и использовании средств избирательных фондов. Данные правонарушения отличаются высокой степенью латентности. После их совершения осуществляются активные действия по сокрытию следов противоправной деятельности, связанные с уничтожением финансовых документов, искажением бухгалтерской отчетности, переводом на другие должности или увольнением лиц, которым было что-либо известно о ходе финансовых нарушений в процессе проведения избирательной кампании ${ }^{2}$.

В тесной взаимосвязи с незаконным финансированием выборов находится проблема коррупции со стороны выборных должностных лиц и депутатов представительных органов государственной власти и местного самоуправления, которые под воздействием различных российских и зарубежных структур, осуществлявших скрытое финансирование их предвыборных кампаний, принимают решения, наносящие ущерб конституционному строю России. В результате оказания кандидатам, избирательным объединениям и использования ими материально-финансовой поддержки помимо соответствующего избирательного фонда, выборы и их итоги фактически превращаются в процедуру «купли-

\footnotetext{
1 См. Выборы Президента Российской Федерации. 2008: Сборник информационно-аналитических материалов /Центральная избирательная комиссия Российской Федерации. М.: СитиПрессСервис, 2008. С. 101.

${ }^{2}$ См.: Болотских Л.Ю. Выявление, расследование и предупреждение преступлений в сфере проведения федеральных выборов в Российской Федерации. Автореф. дис. ... канд. юрид. наук. М., 2002. С. 11.
} 
продажи» власти ${ }^{1}$. Кандидат, привлекающий средства на проведение избирательной кампании, становится политически зависимым, связанным обязательствами перед теми, кто его финансировал.

Избирательные кампании последних лет свидетельствуют, что повсеместное распространение получает использование кандидатами на выборные должности и подконтрольными им юридическими лицами нелегальных финансовых средств на подкуп избирателей, который уже можно назвать угрозой конституционному строю в ходе избирательных кампаний. Распространенной формой подкупа избирателей является заключение договоров беспроцентного займа, вручение подарков избирателям на дому, продажа товаров по заниженным ценам, организация концертов со свободным входом². Недостаточная эффективность противодействия электоральной коррупции связана с «мягкостью» санкций за осуществление подкупа избирателей и отсутствием юридической ответственности за получение избирателями выгоды материального и (или) нематериального характера за осуществление волеизъявления ${ }^{3}$.

Характер угрозы конституционному строю приобретает в современных условиях организационная, материальная, финансовая и техническая зависимость избирательных комиссий и территориальных подразделений федеральных органов исполнительной власти (в том числе правоохранительных органов) от федеральных должностных лиц и высших должностных лиц субъектов Российской Федерации в процессе организации и проведения выборов ${ }^{4}$.

Зависимость руководителей избирательных комиссий субъектов Российской Федерации, руководителей иных комиссий, действующих на постоянной основе и

${ }^{1}$ См.: Андриянов О., Иванова Т. Тверская застава // Рос. газ. 2007. 25 августа; Дамм И.А. Коррупция в российском избирательном процессе: понятие и противодействие. Автореф. дис. ... канд. юрид. наук. Красноярск, 2006. С. 15; Кабанов П.А., Райков Г.И., Чирков Д.К. Политическая коррупция в условиях реформирования российской государственности на рубеже веков: Монография. М.: Дружба народов, 2008. С. 51, 63; Никитина М. Коррупционная дюжина // Рос. газ. 2007. 7 декабря.

${ }^{2}$ См.: Бутаев В.И., Лысенко В.И., Морозова А.Н. Методическое пособие по оказанию органами внутренних дел содействия избирательным комиссиям в реализации их полномочий и проведении выборов органов государственной власти и органов местного самоуправления. М.: РЦОИТ при ЦИК России, 2007. С. 30; Соловьев С.Г. Денежный подкуп избирателей на муниципальных выборах: проблемы теории и практики // Государственная власть и местное самоуправление. 2006. № 9. С. 20-23.

${ }^{3}$ См. Приложение.

${ }^{4}$ См.: Денисов С.А. Правовая характеристика борьбы правящих групп за сохранение власти на выборах // Избирательное право и избирательный процесс в субъектах Российской Федерации: состояние, проблемы, перспективы. Барнаул.: Изд-во Алтайского гос. ун-та, 2000. С. 116-119. 
являющихся юридическими лицами, от органов государственной власти субъектов Российской Федерации, органов местного самоуправления связана с тем, что региональные органы власти и муниципальные органы осуществляют материальное и социальное обеспечение (в том числе медицинское, санаторно-курортное, жилищно-бытовое, пенсионное) указанных избирательных комиссий. Размер средств, выделяемых на финансирование избирательной комиссии субъекта Российской Федерации, определяется законодательным органом государственной власти субъекта Российской Федерации. Но в одних регионах средств вполне достаточно для издания различных книг и сборников по выборной тематике, проведения конференций и семинаров, в других - едва хватает на зарплату ${ }^{1}$. Аналогичное положение с избирательными комиссиями нижестоящего уровня подтверждает вывод о том, что сумма средств, выделенных комиссии, зависит от взаимоотношений руководителей избирательных комиссий $\quad$ в высшими должностными лицами субъектов Российской Федерации.

Наименее самостоятельны территориальные и участковые избирательные комиссии. Фактически ни одного вопроса, связанного с организацией и проведением выборов, участковые избирательные комиссии самостоятельно решить не могут ${ }^{2}$. Практика выборов свидетельствует, что наиболее зависимы члены избирательных комиссий, работающие на непостоянной основе 3 .

Подконтрольность ряда избирательных комиссий федеральным должностным лицам и руководителям субъектов Российской Федерации позволяет использовать в конъюнктурных политических интересах существующую систему выдвижения и регистрации кандидатов, что вносит в избирательную кампанию дополнительные

1 Думается, что материальное и социальное (медицинское, санаторно-курортное, жилищно-бытовое) обеспечение избирательных комиссий должно осуществляться только из федерального бюджета. Федеральное финансирование повысит статус и обеспечит независимость избирательных органов. См. также Полев B.A. К вопросу о независимости избирательных комиссий // Журнал о выборах. 2003. № 2. С. 53; Покровский Е.A. Монолог на выборную тему // Журнал о выборах. 2002. № 4; Добровольский П.Е. О независимости избирательных комиссий муниципальных образований // Административное и муниципальное право. 2008. № 10. С. 10-20.

${ }^{2}$ См.: Избирательное право / Под ред. К.К. Гасанова, А.С. Прудникова. М.: Юнити-Дана: Закон и право, 2007. С. 182. В этой связи авторы (К.К. Гасанов и А.С. Прудников) предлагают все привести к реальной практике и законодательно возложить избирательные функции на органы исполнительной власти и органы местного самоуправления, сохранив избирательные комиссии на общественных началах только на день выборов и определения результатов голосования. Данная инициатива представляется контрпродуктивной. Подобное реформирование избирательной системы будет связано с серьезными издержками, ликвидацией системы самостоятельных избирательных органов, оттоком специалистов в области избирательного права и приведет к еще большей зависимости избирательных комиссий от государственных и муниципальных органов.

${ }^{3}$ См.: Полев В.А. К вопросу о независимости избирательных комиссий // Журнал о выборах. 2003. № 2. С. 54. 
элементы коррумпированности, а также порождает значительное число избирательных споров по поводу отказов в регистрации. В связи с этим в число внутренних угроз следует включить злоупотребление и (или) ненадлежащее осуществление властных полномочий госслужащими и должностными лицами, обеспечивающими организацию и проведение выборов.

Серьезную опасность несут в себе случаи использования должностными лицами избирательных комиссий механизмов фальсификации итогов голосования и результатов выборов ${ }^{1}$. По данным судебной статистики, в Российской Федерации в 2007 г. по статье 142.1 УК РФ «фальсификация итогов голосования» было зарегистрировано 18 преступлений и осуждено 5 человек, в 2008 г. было зарегистрировано 1 преступление и осуждено 2 человека, в 2009 г зарегистрировано 1 преступление и осужден 1 человек². За период с 2005 по 2009 гг. по статье 142 УК РФ «фальсификация избирательных документов, документов референдума» вынесено 10 обвинительных приговоров (по 5 уголовным делам назначено наказание в виде условного лишения свободы, по 5 - в виде штрафа) ${ }^{3}$. Практика избирательных кампаний указывает на то, что итоги голосования и результаты выборов могут быть сфальсифицированы: в ходе манипулирования со списками избирателей (выборы в органы местного самоуправления Цивильского и Вурнарского районов Чувашской Республики в 2005 г., дополнительные выборы депутата Саратовской областной Думы 9 октября 2005 г., выборы глав и депутатов представительных органов сельских поселений Курумканского района Республики Бурятия 12 октября 2008 г.); в ходе противоправного использования бюллетеней для голосования и открепительных удостоверений (муниципальные выборы 19 декабря 2004 г. в Тверской области, муниципальные выборы 19 июня 2005 г. в Чукотском автономном округе, муниципальные выборы 12 марта 2006 г.

1 О законодательных мерах, направленных на предупреждение фальсификаций итогов голосования и результатов выборов, а также обеспечение «прозрачности» избирательного процесса см.: Бабурин С.Н. Особенности правовой системы российско-белорусского Союзного государства / Государствоведение: научные труды. М.: Юнити-Дана, 2010. С. 455.

${ }^{2}$ См.: Волков В.П., Дамаскин О.В., Шапиев С.М. Некоторые проблемы и пути их решения для обеспечения законности избирательного процесса в Российской Федерации. М.: РЦОИТ, 2009. С. 114.

3 См. Записка Правового управления аппарата ЦИК России «Сведения о привлечении к уголовной ответственности членов избирательных комиссий различных уровней в период с 2005 по 2009 годы в соответствии с данными, представленными избирательными комиссиями субъектов Российской Федерации». 4 с. 
в Саратовской области, выборы в Республике Коми 11 марта 2007 г., муниципальные выборы в Тульской области 11 октября 2009 г., выборы главы муниципального образования «городской округ Дербент» Республики Дагестан 11 октября 2009 г.), а также при подсчете голосов избирателей (муниципальные выборы в Краснодарском крае 5 декабря 2004 г., муниципальные выборы в Республике Дагестан 11 марта 2007 г., выборы депутатов Волгоградской городской Думы 2 марта 2008 г., дополнительные выборы депутатов Саратовской городской Думы 2 марта 2008 г.).

Выборы играют важную роль не только во внутренней жизни Российской Федерации, но и являются объектом внешних посягательств некоторых иностранных государств, что, безусловно, имеет значение для защиты конституционного строя России. В связи с этим большое внимание нужно уделить комплексу внешних угроз конституционному строю России, возникающих в избирательном процессе.

В последние годы заметно возросло стремление ряда иностранных государств (прежде всего, Соединенных Штатов) оказывать целенаправленное информационно-пропагандистское, финансовое, политическое и силовое воздействие на избирательный процесс в ущерб конституционному строю Российской Федерации.

В 2007 г. Государственный департамент США подготовил доклад «Поддерживая права человека и демократию», в котором прямо заявлено, что США осуществляют «программную и техническую поддержку» неправительственным организациям, действующим в российских регионах ${ }^{1}$. Проявлением такой поддержки стало создание в США «Фонда в поддержку демократии в России», образование в Украине «Комплексного центра новых независимых государств и стран Балтии для защиты прав человека и гражданского общества». Главной задачей созданных организационных структур является целенаправленное воздействие на общественно-политическую ситуацию

${ }^{1}$ См. Постановление Государственной Думы Федерального Собрания Российской Федерации от 13 апреля 2007 г. № 4434-4 ГД «О Заявлении Государственной Думы Федерального Собрания Российской Федерации «В связи с попытками вмешательства США во внутриполитическую ситуацию в Российской Федерации». 
в Российской Федерации с помощью формирования в России к 2010 году т.н. «единой демократической оппозиции».

Необходимо отметить, что реализация американских стратегических программ установления новых и ликвидации старых политических режимов (поддержка антигосударственных сил и оппозиционной деятельности) традиционно прикрывается гуманитарными интересами (защита прав человека, распространение демократических ценностей и свобод, борьба с коррупцией, терроризмом и т.п.). Сложно оспаривать важность борьбы с коррупцией, необходимость оппозиционной деятельности и защиты прав человека и гражданина в любом современном государстве, если речь не идет о предлогах для информационно-пропагандистского, финансового, политического и военного вмешательства во внутренние дела другого государства, полной или частичной ликвидации его суверенитета, формирования управляемой извне системы органов государственной власти и управления и изменения политики данного государства.

Впервые после распада двухполюсной мировой системы возможности целенаправленного иностранного воздействия на избирательный процесс были продемонстрированы в ходе выборов Президента Югославии 2000 г. Этот опыт управления выборами был успешно распространен на Грузию и Украину.

Можно выделить общую модель захвата политической власти, связанную с использованием выборов для осуществления «цветных» революций в Сербии, Грузии, Украине, Кыргызстане, Монголии, Молдавии и Иране. Она базируется на том, что любая «цветная» революция может быть охарактеризована по ряду критериев: субъекты управляющего воздействия на избирательный процесс; технологии оппозиционной борьбы; информационно-пропагандистское сопровождение; подмена народного волеизъявления внешней легитимацией захвата политической власти.

Во всех анализируемых случаях присутствовали аналогичные субъекты управляющего воздействия на избирательный процесс - ключевая роль принадлежала иностранным неправительственным организациям. Как правило, традиционными организаторами «повстанческого движения» в иностранных 
государствах являются американские неправительственные организации «Институт «Открытое общество» и сеть фондов Copoca» (Open Society Institute and Soros Foundation Network), Национальный Фонд поддержки демократии (National Endowment for Democracy), Международный фонд избирательных систем «Фридом Хayc» (Freedom House) ${ }^{1}$. Эти структуры, используемые спецслужбами США, негласно финансируют интересующих их кандидатов и политические партии, обучают активистов для участия в акциях протеста, оказывают методическую помощь отдельным избирательным штабам, консультируют кандидатов и их доверенных лиц, оказывают давление на иностранных и международных наблюдателей. Например, за период с 1998 по 2000 год в Сербию через сеть фондов Сороса и Национальный Фонд поддержки демократии поступило более 94, 6 миллионов долларов, которые распределялись между оппозиционными партиями и движениями. С 2000 по 2004 год Госдепартамент США выделил украинской оппозиции около 65 миллионов долларов. Для организации «тюльпановой революции» по линии Госдепартамента США неправительственным организациям, действующим в Кыргызстане, было выделено более 70 миллионов долларов 2 .

Как отмечает С.Н. Бабурин, «цветные революции» приурочиваются к выборам, ставка изначально делается на молодежный романтизм и радикализм, раскол в политических элитах, поддержку прозападной оппозиции» ${ }^{3}$. Иностранные неправительственные организации и представители оппозиции активно используют студенческие организации в качестве мобильных и радикально-настроенных участников «революционных» событий. Так, ведущую роль в агитации против С. Милошевича и организации массовых беспорядков на улицах г. Белграда сыграла студенческая организация «Отпор». Организатором

1 О роли американских неправительственных организаций в организации и проведении «цветных революций» в Сербии, Грузии, Украине, Киргизии см. Renate Flottau, Erich Follath, Uwe Klussmann, Georg Mascolo, Walter Mayr, Christian Neef. Die Revolutions-GmbH: Helden unserer Zeit - wie eine neue Generation autokratische Regime in Osteuropa und Zentralasien stuerzt // Der Spiegel. 46/2005 vom 14.11.2005. S. 178; Renate Flottau, Erich Follath, Uwe Klussmann, Georg Mascolo, Walter Mayr, Christian Neef. Die Revolutions-GmbH: Findet der naechste Volksaufstand im weissrussischen Minsk statt? // Der Spiegel. 47/2005 vom 21.11.2005. S. 184; Борисов Т. Платежки и долги // Рос. газ. 2007. 9 августа.

${ }^{2}$ См.: Кузьмин В. Роль США в осуществлении «цветных революций» в зарубежных странах // Зарубежное военное обозрение. 2008. № 9 (738). С. 9-18.

${ }^{3}$ См.: Бабурин С.Н. Российский путь / Современный русский консерватизм: научные труды. М.: ЮнитиДана, 2010. С. 100. 
массовых акций в Грузии выступила радикальная студенческая организация «Кмара». В Украине действовала студенческая организация «Пора», инициировавшая акции протеста на Майдане.

Другим критерием является применение схожих технологий оппозиционной борьбы. Можно назвать их «катализирующими» технологиями, поскольку их использование направлено на обострение социально-политической напряженности в стране, вовлечение в политическую борьбу максимального количества участников, привлечение внимания мировой общественности (прежде всего, США) к происходящим событиям. Используемые для этого противоправные действия (несанкционированные митинги, захваты и блокирование государственных органов, организация массовых беспорядков, создание незаконных военизированных формирований, вмешательство в работу избирательных комиссий и органов конституционного правосудия), как правило, остаются безнаказанными, поскольку осуществляются под прикрытием оппозиционной борьбы и имеют выраженную политическую окраскуํㅗ В 2005 г. по указанному сценарию были организованы массовые беспорядки в Кыргызстане (т.н. «тюльпановая революция»), а в 2009 г. - в Кишиневе и Тегеране.

Публичная деятельность оппозиции начинается с митингов против нарушений законодательства о выборах. Организаторами поднимается тема фальсификации результатов выборов и использования кандидатами «административного ресурса» (именно так начинались «цветные» революции в 2000 г. в Сербии, в 2003 г. в Грузии, в 2004 г. в Украине, в 2005 г. в Кыргызстане, в 2008 г. в Монголии, в 2009 г. в Молдавии и Иране). По мере вовлечения в акции протеста все большего количества участников возникают призывы к продолжению демонстраций и приданию протестным акциям бессрочного характера, осуществляется блокирование важнейших государственных учреждений и органов государственной

1 Политизация конституционного правосудия Украины в условиях «оранжевой» революции показана в работе Д.С. Петренко. См.: Петренко Д.С. Органы конституционного правосудия как участники политических отношений / Актуальные проблемы современного российского государствоведения. 2009. Вып. 2 / Под ред. С.Н. Бабурина М.: Изд-во РГТЭУ, 2009. С. 260-264. 
власти. Организуются суточные дежурства оппозиционеров. Устраиваются палаточные лагеря. «Спонтанные» акции гражданского неповиновения общественности организованно перерастают в массовые беспорядки.

Следующий этап оппозиционной борьбы связан с выборной технологией, позволяющей легально захватывать политическую власть и менять государственно-политический режим. Речь идет о так называемом «внешнем голосовании». Данная технология используется при повторном голосовании или после официального объявления результатов выборов в случае незначительного перевеса голосов, поданных за того или иного кандидата. Поражение на выборах объясняется массовыми нарушениями, допущенными кандидатом-оппонентом, результаты обжалуются в судебном порядке, распространяется обращение к мировой общественности (в лице США и ЕС) с просьбой о непризнании результатов выборов. При этом народное волеизъявление технически подменяется внешним признанием результатов выборов ${ }^{1}$.

Примером могут служить выборы Президента Югославии в 2000 г. Еще до выборов официальные лица США обвиняли югославское правительство в фальсификации выборов. Уже в день выборов, до подсчета голосов, Демократическая Оппозиция Сербии объявила о победе своего кандидата. Никаких оснований для этого не было. Оппозиция и не собиралась признавать выборы, какими бы ни были их результаты. Аналогичная технология был использована 21 ноября 2003 г. как повод для «революции роз», когда Госдепартамент США официально объявил результаты выборов в парламент Грузии сфальсифицированными. «Внешнее голосование» состоялось и 21 ноября 2004 г., когда В. Ющенко попросил страны ЕС и США не признавать итоги украинских выборов. В июне 2009 г. данная технология была успешно апробирована кандидатом в Президенты Ирана Мир-Хуссейном Муссави.

Внешняя легитимация захвата политической власти сопровождается мощным информационно-пропагандистским давлением, в том числе и по дипломатическим каналам (заявления официальных представителей

\footnotetext{
${ }^{1}$ См.: Кара-Мурза С.Г. Указ. соч. С. 254, 260.
} 
Государственного Департамента США, Европарламента, Парламентской Ассамблеи Совета Европы, выступления наблюдателей Бюро по демократическим институтам и правам человека ОБСЕ) ${ }^{1}$.

Наиболее острые формы иностранное вмешательство в избирательный процесс приобрело в ноябре 2004 - январе 2005 г. в ходе украинской «оранжевой революции» и «зеленой» революции в Иране в июне 2009 г.

Выборы в Украине подтвердили высокую эффективность использования «управляемых» избирательных кампаний как механизмов захвата власти и реализации внешней политики. Соединенные Штаты Америки через Фонд Сороса, Национальный Фонд поддержки демократии, Международный центр по ненасильственным конфликтам, Международный республиканский институт, «Freedom House» и другие иностранные неправительственные организации осуществляли финансовую поддержку оппозиции, готовили активистов для массовых акций протеста, в задачу которых входила дестабилизация и последующая смена политического режима, оказывали давление на международных наблюдателей, аккредитованных на выборах ${ }^{2}$. При этом преследовалась цель - поставить под сомнение результаты выборов, добиться признания нелигитимности международным сообществом избранных органов государственной власти.

Сценарий «иранских» событий 2009 г. имел особенности.

Во-первых, организация и проведение «цветной» революции в Иране осуществлялись с учетом религиозного фактора. Требования Муссави отменить результаты выборов сочетались с его призывами уважать мусульманскую систему ценностей Исламской Республики. Мнение духовенства имело ключевое значение при решении вопроса об аннулировании результатов состоявшихся выборов. 23 июня 2009 г. именно Совет стражей принял решение об отказе в отмене результатов выборов.

1 Деятельность данных структур, направленная на дестабилизацию обстановки в Украине, нагнетание оппозиционных настроений, оказание давления на органы государственной власти в условиях выборов была подвергнута обоснованной критике в Заявлении Государственной Думы Федерального Собрания Российской Федерации от 3 декабря 2004 г. «О попытках деструктивного вмешательства извне в развитие ситуации в Украине» // С3 РФ. 2004. № 50. Ст. 4997.

${ }^{2}$ См.: Кузьмин В. Роль США в осуществлении «цветных революций» в зарубежных странах // Зарубежное военное обозрение. 2008. № 9. С. 9-18. 
Во-вторых, для «иранского» варианта было характерно использование как официальными властями, так и оппозиционными силами современных информационных технологий. В ходе осуществления предвыборной агитации, а также для последующей мобилизации отдельных групп населения на участие в массовых демонстрациях протеста силами оппозиции широко использовались электронные СМИ, возможности сети «Интернет». В связи с необходимостью противодействия эскалации насилия и локализации массовых беспорядков официальные власти провели кратковременное отключение мобильных сетей, ограничили доступ к ряду сайтов и заблокировали отправку SMS - сообщений.

События, произошедшие в Тегеране после президентских выборов 2009 г., продемонстрировали всему миру эффективные возможности использования модели «цветных» революций для подрыва конституционного строя даже в консервативных религиозных государствах.

Грозит ли России сценарий «управляемых выборов», захват политической власти и ненасильственная смена государственно-политического режима? Думается, что подобную опасность нельзя недооценивать.

Даже в современном ослабленном виде Российская Федерация представляет собой огромное государство, обладающее уникальным ресурсным потенциалом, ядерным оружием и претендующее на активное участие в решении ключевых вопросов мировой политики. Вместе с тем, наиболее преемлемым для Запада вариантом является государство-колония с гипертрофированной сырьевой экономикой, контролируемым ядерным боезапасом, обладающее значительной территорией для захоронения вредных отходов и размещения экологически опасных производств ${ }^{1}$. C учетом этого ограничение (ликвидация) государственного суверенитета Российской Федерации, противодействие развитию многоукладной национальной экономики, формирование управляемой извне системы органов государственной власти и управления представляются весьма привлекательными.

${ }^{1}$ См. также: Бабурин С.Н. Предотвратить экспансию НАТО на Восток, или почему Россия против второй «холодной» войны // Международный диалог. ИМЭПИ РАН. 1998. № 1. С. 33-53; Бабурин С.Н. Глобализация и борьба России за свое национальное развитие / Государствоведение: научные труды. М.: Юнити-Дана, 2010. С. 578. 
В настоящее время представителями иностранных государств предпринимаются попытки продвижения своих кандидатов в органы государственной власти и местного самоуправления Российской Федерации. Вмешательство спецслужб и организаций ряда иностранных государств в избирательный процесс в России преследует, главным образом, следующую цель сформировать из числа депутатов и выборных должностных лиц разных уровней «лобби», способное в силу занимаемого положения принимать законы и решения, выгодные отдельным иностранным государствам; стимулировать центробежные и дезинтеграционные процессы в субъектах Российской Федерации; осуществлять в ходе избирательных кампаний легальный сбор и добывание информации о социально-экономической и политической обстановке; проводить подбор и изучение возможных агентов влияния из числа перспективных и ныне действующих «народных» избранников в органах государственной власти и местного самоуправления. В этой связи конкретным кандидатам, представляющим интерес для иностранных государств, в ходе выборов организуется информационнопропагандистская, финансовая и политическая поддержка со стороны соответствующих зарубежных общественных организаций, неправительственных фондов, иных негосударственных структур и частных лиц.

В период выборов серьезные опасения вызывает стремление отдельных спецслужб и организаций иностранных государств использовать российские СМИ для нанесения ущерба суверенитету и территориальной целостности Российской Федерации, разжигания социальной, расовой, национальной и религиозной вражды, инспирирования сепаратистских настроений и межнациональных обострений в субъектах Российской Федерации. Ведущие иностранные государства могут использовать в своих интересах информационную, программную и технологическую зависимость России, в том числе в избирательном процессе.

Таким образом, теоретическое изучение выборов в системе народовластия, несмотря на его несовершенство в современной России, указывает на многофункциональный характер данного института. Сущность и значение выборов проявляются во множестве аспектов: они являются конституционно- 
закрепленным институтом (формой) непосредственного народовластия, определяют формирование органов народного представительства, выступают средством активизации населения, устанавливают опосредованную обратную связь между гражданами и депутатами (выборными должностными лицами) в Российской Федерации.

Значение выборов для защиты конституционного строя велико. Периодическое проведение выборов выступает гарантом стабильности институтов государственной власти и местного самоуправления. Приход к власти представителей тех или иных политических сил с помощью выборов обусловливает определенное состояние защищенности конституционного строя и задает параметры государственной политики. От решений, принимаемых органами народного представительства и выборными лицами, зависит степень реализации конституционных прав и свобод граждан, характер средств и методов осуществления государственной власти, дальнейшая судьба населения государства.

Выборы выступают альтернативой силовому сценарию завоевания государственной власти. Выборы служат важнейшим индикатором доверия народа к власти и средством активизации населения. В то же время, в силу социально-политической значимости выборов, они могут являться объектом противоправных устремлений организованных преступных групп, террористических и иных экстремистских организаций и отдельных лиц, а для ряда иностранных государств являются объектом устремлений, направленных на нанесение ущерба конституционному строю России.

\section{2. Теоретико-правовые аспекты регулирования (правового обеспечения) выборов в Российской Федерации}

Особое место в упорядочении общественных отношений, возникающих в процессе организации и проведения выборов, принадлежит нормативному правовому регулированию. Нормативное правовое регулирование имеет общеобязательный характер для субъектов права и распространяется на все общественные отношения определенного рода или вида. 
Предметом нормативного правового регулирования (правового обеспечения) выборов выступает совокупность устойчивых и повторяемых общественных отношений, связанных с реализацией и защитой права граждан (в установленных законом случаях - иностранных граждан) избирать и быть избранными в органы государственной власти и органы местного самоуправления. Эти общественные отношения регулируются императивным (авторитарным) и диспозитивным (автономным) методами ${ }^{1}$. Императивный метод основан на властных предписаниях, имеющих категоричный характер (используется, к примеру, для регламентации образования избирательных округов и участков, финансирования выборов, предвыборной агитации, голосования и др.). Диспозитивный метод предоставляет участникам правоотношений возможность самостоятельно определить вариант своего поведения. Так, правовое регулирование непосредственного выдвижения кандидатов предполагает возможность самовыдвижения или выдвижения избирательным объединением; правовое регулирование предвыборной агитации - возможность выбора методов предвыборной агитации. В ряде случаев используется метод поощрения, который устанавливает меры стимулирования за действия, отвечающие правовым требованиям. В качестве примера можно привести государственное финансирование политической партии, чей федеральный список кандидатов на выборах депутатов Государственной Думы Федерального Собрания Российской Федерации или зарегистрированный кандидат на выборах Президента Российской Федерации получили не менее 3\% голосов избирателей.

Предназначение нормативного правового регулирования состоит в том, чтобы ввести общественные отношения в рамки, обязательные для всех членов общества, придать им определенную устойчивость, упорядоченность, независимость от произвола отдельных личностей.

В ходе нормативного правового регулирования организации и проведения выборов государство устанавливает общие правила поведения, обязательные для

${ }^{1}$ Метод правового регулирования избирательного права сочетает элементы императивно-диспозитивных предписаний, что свойственно нормам практически всех отраслей права и, в силу этого, не обладает какой-либо спецификой. 
всех участников избирательного процесса (например, правила составления списков избирателей, правила регистрации кандидатов (списка кандидатов), правила ведения предвыборной агитации и финансирования избирательной кампании).

Нормативное правовое регулирование представляет собой целенаправленное воздействие компетентных государственных органов на поведение людей и общественные отношения, осуществляемое с помощью правовых норм и обеспечивающее реализацию правовых предписаний путем установления субъективных прав, юридических обязанностей и мер ответственности за неисполнение соответствующих правовых норм.

Для раскрытия содержания нормативного правового регулирования (правового обеспечения) выборов необходимо исследовать понятие «организация и проведение выборов». Представляется, что основные процедуры организации выборов носят вспомогательный характер, в том или ином объеме обслуживают соответствующие стадии проведения выборов, в то время как собственно проведение выборов обеспечивает функциональную завершенность всей работы по подготовке к выборам.

Организация и проведение выборов осуществляется в рамках избирательной кампании и призвана обеспечивать совершение установленных законом избирательных действий и избирательных процедур, гарантирующих реализацию и защиту конституционного права граждан России избирать и быть избранными в органы государственной власти и органы местного самоуправления. Наиболее близким к «организации и проведению выборов» является понятие «избирательного процесса».

В широком смысле термин «избирательный процесс» совпадает с термином «избирательная кампания по подготовке и проведению выборов» и охватывает период со дня официального опубликования решения о назначении выборов до дня представления избирательной комиссией, организующей выборы, отчета о расходовании средств соответствующего бюджета, выделенных на подготовку и проведение выборов. В узком смысле «избирательный процесс» включает 
установленную законом совокупность стадий, обеспечивающих его целостность и легитимность результатов выборов ${ }^{1}$. Ю.А. Дмитриев и В.Б. Исраелян рассматривают избирательный процесс в качестве технологической инфраструктуры и формы реализации конституционных принципов организации периодических свободных выборов и обеспечения избирательных прав человека и гражданина в рамках предусмотренной законом последовательности совершения комплекса избирательных действий и избирательных процедур ${ }^{2}$. М.В. Баглай акцентирует внимание не на функциональной, а на юридической составляющей выборов и рассматривает избирательный процесс как сложную систему правоотношений, в которых участвуют избиратели, средства массовой информации, политические партии, общественные организации и государственные органы по проведению выборов ${ }^{3}$.

Существующий в Российской Федерации процесс избрания органов государственной власти и местного самоуправления состоит из целого ряда самостоятельных стадий ${ }^{4}$.

К числу основных стадий избирательного процесса относятся: назначение выборов; составление списков избирателей; образование избирательных округов, избирательных участков; формирование избирательных комиссий; выдвижение и регистрация кандидатов (списков кандидатов); финансирование; информирование избирателей и предвыборная агитация; голосование и определение результатов

\footnotetext{
${ }^{1}$ См.: Избирательное право и избирательный процесс в Российской Федерации: Учебник для вузов / Под ред. А.В. Иванченко. М.: НОРМА, 1999. С. 259.

${ }^{2}$ См.: Дмитриев Ю.А., Исраелян В.Б. Избирательное право и процесс в Российской Федерации. Ростов-наДону: Феникс, 2004. С. 506.

${ }^{3}$ См.: Баглай М.В. Конституционное право Российской Федерации. М.: Норма, 2006. С. 401.

${ }^{4}$ В юридической литературе отсутствует единое мнение по вопросу разделения избирательного процесса на стадии. Так, Е.И. Козлова и О.Е. Кутафин не рассматривают избирательный процесс и его стадии. По мнению М.Ф. Чудакова и В.В. Маклакова, избирательный процесс состоит из 12 стадий. Е.А. Хрусталев является сторонником дробления избирательного процесса на 9 стадий. Автор полагает, что выделение в избирательном процессе большого количества стадий неоправданно и поэтому придерживается более распространенной точки зрения (Р.Т..Биктагиров, Ю.А. Веденеев, А.А. Вешняков, Ю.А. Дмитриев, В.Б. Исраелян, С.Д. Князев, В.И. Лысенко) о разделении избирательного процесса на основные и факультативные стадии. А.С. Прудников и В.И. Авсеенко именуют основные стадии обязательными. См.: Биктагиров Р.T. Субъект избирательного права Российской Федерации: конституционно-правовое исследование. Автореф. дис. ...Д-ра юрид. наук. М., 2010. С. 4849; Избирательное право и избирательный процесс в Российской Федерации. М., 2003. С. 297; Конституционное право России /Под ред. Е.И. Козловой, О.Е. Кутафина. М., 2007. С. 330-365; Конституционное право России /Под ред. А.С. Прудникова, В.И. Авсеенко. М., 2007. С. 370; Дмитриев Ю.А., Исраелян В.Б. Избирательное право и процесс в Российской Федерации. Ростов-на-Дону: Феникс, 2004. С. 510.
} 
выборов. Факультативными стадиями являются проведение повторного голосования, повторных и дополнительных выборов.

Нормативное правовое регулирование организации и проведения выборов в Российской Федерации охватывает все стадии избирательного процесса выборов всех уровней.

Нормативное правовое регулирование организации и проведения выборов оказывает целенаправленное управляющее воздействие на значительный спектр общественных отношений, складывающихся в ходе выборов, в том числе и на общественные отношения, возникающие в связи с защитой конституционного строя России в избирательном процессе.

Важным направлением разработки теоретических основ нормативного правового регулирования (правового обеспечения) организации и проведения выборов является исследование системы избирательных правовых норм.

В структуре нормативного правового регулирования организации и проведения выборов правовые нормы важны не только потому, что они закрепляют основные гарантии реализации гражданами Российской Федерации избирательных прав, устанавливают прочную юридическую основу, детально и всесторонне определяющую поведение и деятельность участников общественных отношений, связанных с выборами органов и должностных лиц государства и местного самоуправления, на всех стадиях избирательного процесса, но и в связи с тем, что они позволяют понять и выразить суть нормативного регулирования.

Суть нормативного правового регулирования организации и проведения выборов заключается в том, чтобы посредством норм права обязывать, запрещать, дозволять или рекомендовать всем участникам избирательного процесса действия в интересах обеспечения стабильности конституционного строя, устойчивого воспроизводства и функционирования демократических институтов власти, реализации избирательных прав и свобод граждан. Содержание нормативного правового регулирования организации и проведения выборов выступает как внутреннее состояние, характеризующее избирательный процесс. Выражением содержания нормативного правового регулирования в данной сфере 
общественных отношений являются нормы права, детально регламентирующие стадии избирательного процесса. В свою очередь, содержательная сторона организации и проведения выборов в Российской Федерации определяется поставленными законодателем целями нормативного правового регулирования.

Основную цель нормативного правового регулирования можно определить как конечный ожидаемый результат, предполагаемое управомоченным на то органом состояние отношений, для достижения которого предлагается использование определенных правовых норм. Исходя из изложенного, целью нормативного правового регулирования (правового обеспечения) выборов в Российской Федерации выступает упорядоченность, прогрессивное развитие и преобразование общественных отношений, возникающих в избирательном процессе.

Нормативное правовое регулирование организации и проведения выборов в Российской Федерации осуществляется Конституцией Российской Федерации, международными избирательными стандартами, федеральными законами, указами Президента Российской Федерации, постановлениями Правительства Российской Федерации, нормативными правовыми актами ЦИК России, законами и нормативными правовыми актами высших органов исполнительной власти субъектов Российской Федерации, нормативными правовыми актами избирательных комиссий субъектов Российской Федерации ${ }^{1}$.

Наивысшей юридической силой обладают нормы избирательного права, содержащиеся в Конституции Российской Федерации (статьи 3, 11, 12, 32, 55, 56, $71,72,77,81,95-97,109,111,117,130,131)$. Глава 1 Конституции, определяющая основы конституционного строя Российской Федерации, закрепляет, что высшим непосредственным выражением власти народа является референдум и свободные выборы. Нормы Конституции, согласно статье 15, имеют прямое действие. В силу этого, при разрешении избирательных споров обоснована ссылка на нормы Конституции. В главе 2 определяется содержание избирательных прав граждан Российской Федерации. Статьей 32 Конституции установлено, что граждане Российской Федерации имеют право избирать и быть избранными в органы

\footnotetext{
${ }^{1}$ Международное регулирование организации и проведения выборов рассматривается в параграфе 3.1 .
} 
государственной власти и органы местного самоуправления. Какие-либо прямые или косвенные ограничения избирательного права в зависимости от происхождения, социального или имущественного положения, расовой и национальной принадлежности, пола, образования, языка, отношения к религии, политических и иных взглядов, времени проживания в данной местности, рода и характера занятий запрещаются действующим законодательством. В соответствии с международными договорами Российской Федерации, федеральными законами, законами субъектов Российской Федерации иностранные граждане, постоянно проживающие на территории соответствующего муниципального образования, имеют право избирать и быть избранными в органы местного самоуправления на тех же условиях, что и граждане России ${ }^{1}$. Избирательным правом не обладают граждане, признанные судом недееспособными, а также лица, содержащиеся в местах лишения свободы по приговору суда²

Согласно федеральным законам иностранные граждане и апатриды лишены права участвовать в выборах в федеральные и региональные органы государственной власти, участвовать в референдуме Российской Федерации и референдумах субъектов Российской Федерации.

Конституция Российской Федерации определяет федеральные государственные органы, избираемые гражданами России, и устанавливает основные положения, связанные с их избранием. К числу таких органов относятся Президент Российской Федерации (статья 81 Конституции) и одна из палат Федерального Собрания Российской Федерации - Государственная Дума (статья 96 Конституции).

Развивая конституционные нормы, федеральное законодательство более детально регулирует проведение выборов Президента Российской Федерации и депутатов Государственной Думы Федерального Собрания Российской Федерации.

1 См. Статья 12 Федерального закона от 25 июля 2002 г. (в ред. от 27 декабря 2009 г.) № 115-Ф3 «О правовом положении иностранных граждан в Российской Федерации», пункт 10 статьи 4 Федерального закона от 12 июня 2002 г. (в ред. от 22 апреля 2010 г.) № 67-Ф3 «Об основных гарантиях избирательных прав и права на участие в референдуме граждан Российской Федерации».

2 Ограничения избирательного права, установленные федеральными законами в целях защиты конституционного строя и безопасности государства в соответствии с частью 3 статьи 55 Конституции Российской Федерации, рассматриваются в параграфе 3.2. 
Выборы Президента Российской Федерации проводятся на основе Федерального закона от 10 января 2003 года (в ред. от 22 апреля 2010 г.) № 19-Ф3 «О выборах Президента Российской Федерации» ${ }^{1}$. Данный закон устанавливает основные принципы проведения выборов Президента Российской Федерации, регламентирует конкретные стадии выборов Президента Российской Федерации. Отдельная глава (X) посвящена процедуре вступления Президента в должность. В главе XI закреплен порядок обжалования нарушений избирательных прав граждан и ответственность за нарушения законодательства о выборах Президента Российской Федерации.

Порядок избрания депутатов Государственной Думы Федерального Собрания Российской Федерации определяет Федеральный закон от 18 мая 2005 г. (в ред. от 22 апреля 2010 г.) № 51-Ф3 «О выборах депутатов Государственной Думы Федерального Собрания Российской Федерации»². В нем зафиксированы общие положения выборов депутатов Государственной Думы, регулируется порядок осуществления избирательных процедур и действий, закреплен статус кандидатов, описан порядок замещения вакантных депутатских мандатов и установлена ответственность за нарушения законодательства о выборах депутатов Государственной Думы Федерального Собрания Российской Федерации.

Особое место в системе источников избирательного права занимает Федеральный закон от 12 июня 2002 г. (в ред. от 22 апреля 2010 г.) № 67-Ф3 «Об основных гарантиях избирательных прав и права на участие в референдуме граждан Российской Федерации» ${ }^{3}$. Он имеет универсальный характер, так как в нем устанавливаются гарантии избирательных прав, общие для всех выборов независимо от их уровня, и его действие распространяется также на референдумы, проводимые в России. Кроме того, он конкретизирует содержание конституционного права граждан избирать и быть избранными, формулирует гарантии реализации избирательных прав применительно ко всем стадиям

\footnotetext{
${ }^{1}$ См. Рос. газ. 2003. 16 января; 2005. 26 июля; 2006. 15 июля; 2006. 27 июля; 2007. 10 января; 2007. 11 мая; 2007. 1 августа; 2009. 11 февраля; 10 июня; 21 июля; 2010. 26 апреля.

${ }^{2}$ См. Рос. газ. 2005. 24 мая; 2006. 15 июля; 2006. 27 июля; 2007. 10 января; 2007. 11 мая; 2007. 25 июля; 2007. 1 августа; 2009. 11 февраля; 10 июня; 21 июля; 2010. 26 апреля.

${ }^{3}$ См. Рос. газ. 2002. 15 июня; 2002. 28 сентября; 2003. 25 июня; 2003. 8 июля; 2004. 9 июня; 2004. 14 августа; 2004. 31 августа; 2004. 15 декабря; 2005. 2 июля; 2005. 26 июля; 2006. 15 июля; 2006. 27 июля; 2006. 7 декабря; 2007. 10 января; 2007. 2 февраля; 2007. 6 марта; 2007. 24 апреля; 2007. 11 мая; 2007. 1 августа; 2008.25 июля; 2008. 28 ноября; 2008. 31 декабря; 2009. 11 февраля; 2009. 8 апреля; 10 июня; 21 июля; 2010. 26 апреля.
} 
избирательного процесса, определяет основные понятия избирательного права, устанавливает порядок обжалования нарушений избирательных прав, а также основания и формы юридической ответственности за нарушение избирательных прав. Указанный федеральный закон имеет прямое действие и применяется на всей территории Российской Федерации.

Согласно пункту 6 статьи 1 настоящего закона, в случае, если федеральные законы, конституции (уставы), законы субъектов Российской Федерации, иные нормативные правовые акты о выборах, принимаемые в Российской Федерации противоречат ему, применяются нормы данного закона. Данное положение о верховенстве юридической силы Федерального закона «Об основных гарантиях избирательных прав и права на участие в референдуме граждан Российской Федерации» над другими федеральными законами вызывает обоснованные сомнения, поскольку нарушает установленную Конституцией Российской Федерации иерархию нормативных правовых актов ${ }^{1}$. Общепринятые правила разрешения юридических коллизий в этом случае не действуют. Во-первых, при конкуренции общей и специальной норм приоритет отдается специальной норме ${ }^{2}$. Во-вторых, при коллизии норм, содержащихся в нормативных правовых актах равной юридической силы, принятых в разное время, приоритет отдается норме, принятой позднее ${ }^{3}$. По мнению ряда ученых-юристов и специалистов-практиков, в случае возможного возникновения коллизии между нормативными установлениями Федерального закона «Об основных гарантиях избирательных прав и права на участие в референдуме граждан Российской Федерации» и других федеральных законов о выборах, анализируемая норма пункта 6 статьи 1 открывает возможности для варьирования и использования правовых положений в своих интересах в зависимости от ситуации ${ }^{4}$.

Отношения, возникающие при использовании Государственной автоматизированной системы Российской Федерации «Выборы» (ГАС «Выборы») при подготовке и проведении выборов, при эксплуатации и развитии ГАС

\footnotetext{
${ }^{1}$ См.: Боброва Н.А. Конституционный строй и конституционализм в России. Монография. М.: Закон и право, 2003. C. 219.

2 «Специальный закон отменяет общий закон» - Lex specialis derogat generalis.

3 «Последующий закон отменяет предыдущий» - Lex posteriori derogat priori.

${ }^{4}$ См.: Скосаренко Е.Е. Избирательная система России: мифы и политическая реальность. М.: Формула права, 2007. C. 88 .
} 
«Выборы», а также при решении с ее использованием задач, не связанных с выборами, регулируются Федеральным законом от 10 января 2003 г. (в ред. от 25 декабря 2008 г., с изм. от 8 мая 2010 г.) № 20-Ф3 «О Государственной автоматизированной системе Российской Федерации «Выборы» 1 .

Среди актов федерального избирательного законодательства выделяется Федеральный закон от 26 ноября 1996 г. № 138-Ф3 (в ред. от 9 ноября 2009 г.) «Об обеспечении конституционных прав граждан Российской Федерации избирать и быть избранными в органы местного самоуправления», в котором установлены временные правила назначения и проведения муниципальных выборов для тех субъектов Российской Федерации, в которых отсутствует законодательная база для выборов в органы местного самоуправления².

Федеральным законом от 25 ноября 2008 г. № 222-Ф3 «О внесении изменений в отдельные законодательные акты Российской Федерации в связи с совершенствованием организации местного самоуправления» установлены положения, определяющие особенности формирования представительных органов вновь образованных муниципальных образований в ходе реформы системы местного самоуправления ${ }^{3}$.

Федеральный закон от 11 июля 2001 г. № 95-Ф3 «О политических партиях» (в ред. от 6 мая 2010 г.) регулирует особенности создания, деятельности, реорганизации и ликвидации политических партий в Российской Федерации, участие политических партий в выборах и референдумах, основание и объем получения государственного финансирования партий, принимающих участие в выборах 4 .

Федеральный закон от 6 октября 1999 г. (в ред. от 5 апреля 2010 г.) № 184-Ф3 «Об общих принципах организации законодательных (представительных) и исполнительных органов государственной власти субъектов Российской Федерации» определяет требования к кандидатуре высшего должностного лица

\footnotetext{
${ }^{1}$ См. Рос. газ. 2003. 15 января; 2008. 30 декабря.

${ }^{2}$ См. Рос. газ. 1996. 4 декабря; 2006. 15 июля.

${ }^{3}$ См. СЗ РФ. 2008. № 48. Ст. 5517.

${ }^{4}$ См. СЗ РФ. 2001. № 29. Ст. 2950; 2002. № 12. Ст. 1093; 2002. № 30. Ст. 3029; 2003. № 26. Ст. 2574; 2003 . № 50. Ст. 4855; 2004. № 52 (ч. 1). Ст. 5272; 2005. № 1 (ч. 1). Ст. 9; 2005. № 30 (ч. 1). Ст. 3104; 2006. № 1. Ст. 13; 2006. № 29. Ст. 3124; 2007. № 1 (ч. 1). Ст. 37; 2007. № 18. Ст. 2118; 2008. № 30 (ч. 1). Ст. 3600; 2008. № 30 (ч. 2). Ст. $3616 ; 2008$. № 45. Ст. 5146; 2009. № 14. Ст. 1577; 2009. № 44. Ст. 5170; 2010. № 19. Ст. 2288.
} 
субъекта Российской Федерации (руководителя высшего исполнительного органа государственной власти субъекта Российской Федерации), порядок наделения полномочиями и правосубъектность указанных должностных лиц ${ }^{1}$. В статье 26.1 Федерального закона «О политических партиях» изложен порядок внесения предложений политических партий о кандидатурах на должность высшего должностного лица субъекта Российской Федерации, а также процедура консультаций и рассмотрения предложений о кандидатурах ${ }^{2}$.

Помимо перечисленных, к числу важных нормативных правовых актов федерального значения, регулирующих отношения в рассматриваемой сфере, относятся также Закон Российской Федерации от 27 декабря 1991 г. № 2124-1 (в ред. Федерального закона от 9 февраля 2009 г.) «О средствах массовой информации» и Федеральный закон от 6 октября 2003 г. (в ред. от 5 апреля 2010 г.) № 131-Ф3 «Об общих принципах организации местного самоуправления в Российской Федерации». Проживание гражданина на территории избирательного участка, являющееся основанием для включения его в список избирателей, устанавливается в соответствии с Законом Российской Федерации «О праве граждан Российской Федерации на свободу передвижения, выбор места пребывания и жительства в пределах Российской Федерации». Приведенный перечень нормативных правовых актов не является исчерпывающим.

Рассмотрев федеральный уровень нормативного правового регулирования организации и проведения выборов в России, остановимся на некоторых аспектах, характеризующих законодательство субъектов Российской Федерации в этой cфepe.

Исходя из требований статьи 73 Конституции и Федерального закона от 6 октября 1999 года № 184-Ф3, целый ряд вопросов избирательного процесса

\footnotetext{
${ }^{1}$ См. СЗ РФ. 1999. № 42. Ст. 5005; 2000. № 31. Ст. 3205; 2001. № 7. Ст. 608; 2002. № 19. Ст. 1792; 2002. № 30. Ст. 3024; 2002. № 50. Ст. 4930; 2003. № 27 (ч. 2). Ст. 2709; 2004. № 25. Ст. 2484; 2004. № 50. Ст. 4950; 2005. № 1 (ч. 1). Ст. 17; 2005. № 30 (ч. 1). Ст. 3104; 2006. № 1. Ст. 10; 2006. № 1. Ст. 13; 2006. № 29. Ст. 3124; 2006. № 30. Ст. 3287; 2006 . № 31 (ч. 1). Ст. 3427; 2006. № 31 (ч. 1). Ст. 3452; 2006. № 44. Ст. 4537; 2006. № 50. Ст. 5279; 2007. № 1 (ч. 1). Ст. 21 ; 2007. № 10. Ст. 1151; 2007. № 13. Ст. 1464; 2007. № 18. Ст. 2117; 2007. № 21. Ст. 2455; 2007. № 26. Ст. 3074; 2007. № 43. Ст. 5084; 2007. № 46. Ст. 5553; 2008. № 13. Ст. 1186; 2008 . № 29 (ч. 1). Ст. 3418; 2008. № 30 (ч. 1). Ст. 3597; 2008. № 30 (ч. 2). Ст. 3616; 2008. № 48. Ст. 5516; 2008. № 49. Ст. 5747; 2008. № 52 (ч. 1). Ст. 6236; 2009. № 7. Ст. 772; 2009. № 29. Ст. 3612; 2010. № 15. Ст. 1736.

2 Процедура наделения высшего должностного лица субъекта Российской Федерации полномочиями юридически представляет собой косвенные выборы. Вместе с тем, учитывая представительный характер этой процедуры формирования высшего исполнительного органа государственной власти, отсутствие непосредственной правовой связи данных выборов с избирателями, невозможность выделения в структурнофункциональном смысле традиционных стадий избирательного процесса, правоотношения, возникающие в ходе косвенных выборов высшего должностного лица субъекта Российской Федерации, в работе не рассматриваются.
} 
субъекты Российской Федерации решают самостоятельно. В частности, законодательные органы субъектов Российской Федерации определяют законами наименование своего законодательного органа, его структуру, число избираемых депутатов ${ }^{1}$, сроки их полномочий, порядок проведения выборов в законодательный орган субъекта Российской Федерации. Субъект Российской Федерации самостоятельно определяет конкретную дату выборов этого органа, в том числе внеочередных выборов в случае досрочного прекращения полномочий законодательного органа государственной власти субъекта Российской Федерации и т.д.

В последние годы наметилась тенденция расширения сферы законодательного регулирования Российской Федерацией выборов (изменение порядка проведения выборов в законодательный орган государственной власти субъекта Российской Федерации, установление требований к числу депутатов законодательного органа государственной власти субъекта Российской Федерации, законодательные инициативы об унификации структуры и наименований законодательных органов субъектов Российской Федерации) ${ }^{2}$. Эта тенденция носит разнонаправленный характер. С одной стороны, федеральное вмешательство в региональный законодательный процесс позволяет устранять недостатки законодательных актов субъектов Российской Федерации и тем самым обеспечивать единство правового пространства Российской Федерации. С другой стороны, ограничиваются конституционные полномочия субъектов Российской Федерации в сфере совместного ведения Российской Федерации и субъектов Российской Федерации, что противоречит пункту «н» части 1 статьи 72

1 В Послании Федеральному Собранию Российской Федерации 12 ноября 2009 г. Президент России предложил ввести единый критерий установления численности депутатов органов законодательной власти субъектов Российской Федерации. Данная инициатива главы государства реализована в Федеральном законе от 5 апреля 2010 г. № 42-Ф3 «О внесении изменений в статью 4 Федерального закона «Об общих принципах организации законодательных (представительных) и исполнительных органов государственной власти субъектов Российской Федерации» в связи с установлением требований к числу депутатов законодательного (представительного) органа государственной власти субъекта Российской Федерации» // С3 РФ. 2010. № 15. Ст. 1738.

2 См. Федеральный закон от 21 июля 2005 г. № 93-Ф3 «О внесении изменений в законодательные акты Российской Федерации о выборах и референдумах и иные законодательные акты Российской Федерации»; Федеральный закон от 5 апреля 2010 г. № 42-Ф3 «О внесении изменений в статью 4 Федерального закона «Об общих принципах организации законодательных (представительных) и исполнительных органов государственной власти субъектов Российской Федерации» в связи с установлением требований к числу депутатов законодательного (представительного) органа государственной власти субъекта Российской Федерации»; проект Федерального закона № 304313-5 «О внесении изменений в отдельные законодательные акты Российской Федерации и признании утратившими силу отдельных положений законодательных актов Российской Федерации». 
Конституции Российской Федерации, пунктам 3 и 6 статьи 4, подпункту «к» пункта 2 статьи 5 Федерального закона от 6 октября 1999 г. № 184-Ф3¹.

Следует отметить, что в Конституции не всегда достаточно четко осуществляется разграничение предметов ведения Российской Федерации и совместного ведения Федерации и ее субъектов. Так, пункт «в» статьи 71 Конституции Российской Федерации определяет, что регулирование и защита прав и свобод человека и гражданина (следовательно, и избирательных прав) находится в ведении Российской Федерации. В то же время, пункт «б» части 1 статьи 72 Конституции защиту прав и свобод человека и гражданина относит к совместному ведению Российской Федерации и субъектов Российской Федерации. Таким образом, не ясно, к какому ведению все-таки относится защита прав и свобод человека и гражданина. Подобная конституционно-правовая коллизия может повлечь неопределенность разграничения федеральных и региональных полномочий в случае необходимости защиты нарушенных прав и свобод граждан (в том числе, в сфере выборов) и возмещения причиненного ущерба.

Избирательное законодательство субъектов Российской Федерации представляет собой совокупность региональных нормативных правовых актов законодательного и подзаконного характера, регулирующих выборы в органы государственной власти субъектов Российской Федерации и муниципальные выборы ${ }^{2}$.

В настоящее время законодательство субъектов Российской Федерации о выборах включает в себя конституции республик, уставы краев, областей, городов федерального значения, автономной области и автономных округов. Данными нормативными правовыми актами устанавливаются нормы, касающиеся определения срока полномочий выборных органов государственной власти,

${ }^{1}$ О проблеме разграничения предметов ведения Российской Федерации и субъектов Российской Федерации см.: Бабурин С.Н. Территориальное, социально-экономическое, политико-правовое единство и перспективы развития российского федерализма / Российский путь: утраты и обретения. М.: Новатор, 1997. 460 с; Бариии И.Н. Федеральное и региональное законодательство: требование соответствия // Право и политика. 2001. № 3. С. 23-24; Вискулова B.B. Пределы самостоятельности субъектов Российской Федерации в свете реформы избирательного законодательства 2005-2006 годов: правовые проблемы // Конституционное и муниципальное право. 2007. № 13. С. $20-26$.

${ }^{2}$ См.: Постников А.Е. Система избирательного законодательства в Российской Федерации. Автореф. дис. ... д-ра юрид. наук. М., 1997. 49 с; Алехичева Л.Г. Соотношение и взаимодействие избирательного законодательства Российской Федерации и ее субъектов: конституционно-правовые основы. Автореф. дис. ... канд. юрид. наук. М., 2000. 23 с; Агаларова K.A. Развитие избирательного законодательства субъектов Российской Федерации: конституционно-правовой анализ. Автореф. дис. ... канд. юрид. наук. М., 2004. 25 с. 
порядка выборов в органы государственной власти субъектов Российской Федерации и органы местного самоуправления, условий реализации гражданами своих избирательных прав.

В конституциях (уставах) некоторых субъектов Российской Федерации в специальных главах закреплены основные организационно-правовые элементы подготовки и проведения выборов, в том числе определен статус избирательных комиссий субъектов Российской Федерации ${ }^{1}$.

Законы субъектов Российской Федерации регулируют порядок выборов в органы государственной власти субъектов Российской Федерации и органы местного самоуправления, основываясь на положениях Конституции Российской Федерации, федеральных конституционных законов, федеральных законов.

Как правило, в систему законодательства о выборах каждого субъекта Российской Федерации входит закон о выборах депутатов законодательного (представительного) органа государственной власти. Примером могут служить законы Кабардино-Балкарской Республики от 5 августа 2008 г. (в ред. от 21 июля 2009 г.) № 56-Р3 «О выборах депутатов Парламента Кабардино-Балкарской Республики»; Чеченской Республики от 5 июня 2008 г. № 25-Р3 «О выборах депутатов Парламента Чеченской Республики»; Кемеровской области от 14 февраля 2007 г. (в ред. от 13 октября 2009 г.) № 24-О3 «О выборах депутатов Совета народных депутатов Кемеровской области»; Московской области от 26 октября 2006 г. (в ред. от 4 декабря 2009 г.) № 191/2006-О3 «О выборах депутатов Московской областной Думы».

К системе регионального избирательного законодательства следует отнести имеющиеся во всех субъектах Российской Федерации законы об избирательной комиссии субъекта Российской Федерации либо о системе избирательных комиссий в субъекте Российской Федерации.

\footnotetext{
${ }^{1}$ См.: Конституция Республики Саха (Якутия) от 4 апреля 1992 г. (в ред от 10 июля 2003 г.). Глава 7. Избирательная система; Конституция Республики Тыва от 6 мая 2001 г. (в ред от 11 апреля 2010 г.) Глава III. Выборы и референдум; Устав Еврейской автономной области от 8 октября 1997 г. (в ред. от 29 апреля 2009 г.) № 40-О3. Глава II. Организация государственной власти. Избирательная система, референдум; Устав (Основной Закон) Рязанской области от 2 ноября 2005 г. (в ред. от 18 апреля 2008 г.) Глава 8. Избирательная комиссия Рязанской области; Устав Тверской области от 5 ноября 1996 г. (в ред. от 31 марта 2008 г.). Глава 15. Избирательная комиссия Тверской области, территориальные избирательные комиссии Тверской области; Устав (Основной Закон) Тульской области от 12 ноября 2001 г. (в ред. от 17 декабря 2007 г.) № 265 - 3ТО. Глава 1. Избирательная комиссия Тульской области.
} 
Рядом субъектов Российской Федерации была проведена кодификация регионального законодательства о выборах. По предмету правового регулирования избирательные кодексы субъектов Российской Федерации представлены двумя группами кодифицированных актов:

- кодексами, регламентирующими выборы в органы государственной власти и выборы в органы местного самоуправления (приняты и действуют в Республике Башкортостан, Республике Татарстан, Приморском и Хабаровском краях, Амурской, Воронежской, Костромской, Курской, Псковской, Свердловской, Тверской, Тюменской областях, г. Москве) ${ }^{1}$;

- кодексами, регулирующими избирательные процедуры, референдумы и отзыв (Алтайский край, Белгородская область и Владимирская область) ${ }^{2}$.

В ходе кодификации система разрозненных нормативных правовых актов субъекта Российской Федерации о выборах заменялась единым, логически стройным и непротиворечивым нормативным правовым актом, малоэффективные нормы утрачивали свое действие, создавались и закреплялись новые нормы.

Некоторые особенности имеет нормативное правовое регулирование организации и проведения муниципальных выборов 3 .

Регулирование муниципальных выборов не относится к ведению муниципальных образований, так как согласно пункту 3 статьи 23 Федерального закона от 6 октября 2003 г. № 131-ФЗ (в ред. от 5 апреля 2010 г.) «Об общих принципах организации местного самоуправления в Российской Федерации» гарантии избирательных прав граждан при проведении муниципальных выборов, порядок назначения, подготовки, проведения, установления итогов и определения

\footnotetext{
${ }^{1}$ См.: Закон Воронежской области от 27 июня 2007 г. (в ред. от 11 ноября 2009 г.) № 87-О3 «Избирательный кодекс Воронежской области»; Закон Псковской области от 1 августа 2003 г. (в ред. от 5 ноября 2009 г.) № 295-О3 «Избирательный кодекс Псковской области»; Избирательный кодекс Амурской области от 17 сентября 2003 г. (в ред. от 26 сентября 2008 г.) № 239-О3; Избирательный кодекс Костромской области от 30 декабря 1998 г. (в ред. от 22 июня 2010 г.) № 39; Избирательный кодекс Приморского края от 22 июля 2003 г. (в ред. от 28 июля 2009 г.) № 62-К3; Избирательный кодекс Республики Татарстан от 7 мая 2007 г. (в ред. от 26 декабря 2007 г.) № 21-3РТ; Избирательный кодекс Свердловской области от 24 апреля 2003 г. (в ред. от 27 ноября 2009 г.) № 10-О3; Избирательный кодекс Тверской области от 25 марта 2003 г. (в ред. от 28 мая 2009 г.); Избирательный кодекс (Закон) Тюменской области от 3 июня 2003 г. (в ред. от 7 октября 2009 г.) № 139; Избирательный кодекс Хабаровского края от 26 ноября 2003 г. (в ред. от 25 ноября 2009 г.) № 154; Кодекс Республики Башкортостан о выборах от 6 декабря 2006 г. (в ред. от 16 ноября 2007 г.) № 380-3; Закон г. Москвы от 6 июля 2005 г. № 38 (в ред. от 26 мая 2010 г.) «Избирательный кодекс г. Москвы».

${ }^{2}$ См.: Кодекс Алтайского края о выборах, референдуме, отзыве депутатов от 8 июля 2003 г. (в ред. от 3 июля 2009 г.) № 35-3С; Избирательный кодекс Белгородской области от 7 мая 2007 г. № 108 (в ред. от 2 февраля 2009 г.); Закон Владимирской области от 13 февраля 2003 г. (в ред. от 11 марта 2010 г.) № 10-ОЗ «Избирательный кодекс Владимирской области». 245.

${ }^{3}$ См. Конституционное законодательство России / Под ред. Ю.А. Тихомирова. М.: Городец, 1999. С. 244-
} 
результатов муниципальных выборов устанавливается федеральным законом и принимаемыми в соответствии с ним законами субъектов Российской Федерации. Законом субъекта Российской Федерации устанавливаются виды избирательных систем, которые могут применяться при проведении муниципальных выборов, и порядок их применения ${ }^{1}$.

В соответствии с установленными законом субъекта Российской Федерации видами избирательных систем уставом муниципального образования определяется та избирательная система, которая применяется при проведении муниципальных выборов в данном муниципальном образовании.

Субъекты Российской Федерации регулируют порядок назначения, подготовки и проведения выборов депутатов представительных органов муниципальных образований, членов выборных органов и выборных должностных лиц местного самоуправления, избираемых населением непосредственно ${ }^{2}$.

Федеральные и региональные законодательные акты о выборах занимают главное место в системе нормативного правового регулирования избирательного процесса в Российской Федерации. Они регулируют наиболее важные общественные отношения, связанные с формированием органов народного представительства, и обладают высшей юридической силой в установленной сфере действия.

Важное значение для регламентации избирательного процесса в Российской Федерации имеют подзаконные нормативные правовые акты ${ }^{3}$. Эти акты издаются на основе и во исполнение законов, являясь формой реализации компетенции субъектов правотворчества. Иерархия подзаконных актов, регулирующих

${ }^{1}$ См.: Закон Тульской области от 9 июня 2008 г. № 1024-3ТО «О видах избирательных систем, порядке и условиях их применения при проведении муниципальных выборов в Тульской области».

2 См.: Закон Новгородской области от 30 июля 2007 г. (в ред. от 6 ноября 2009 г.) № 174-О3 «О выборах депутатов представительного органа муниципального образования в Новгородской области»; закон КабардиноБалкарской Республики от 20 августа 2003 г. (с изм. от 21 июля 2009 г.) № 74-РЗ «О выборах депутатов представительных органов местного самоуправления); закон Тамбовской области от 23 июля 2003 г. (в ред. от 2 июля 2008 г.) № 140-3 «О выборах должностных лиц муниципального образования в Тамбовской области»; закон Вологодской области от 17 февраля 2003 г. № 869 -О3 (в ред. от 28 апреля 2010 г.) «О выборах главы муниципального образования в Вологодской области.

3 А.Е. Постников полагает, что акты Президента Российской Федерации, органов исполнительной власти не являются источниками избирательного законодательства. См. Конституционное законодательство России / Под ред. Ю.А. Тихомирова. М.: Городец, 1999. С. 241. Данная точка зрения представляется спорной, поскольку федеральные законы прямо предусматривают возможность правового регулирования избирательного процесса указанными подзаконными актами. Примером могут служить п. 5 ст. 10, п.4-5 ст. 11, п.2 ст. 81 Федерального закона от 12 июня 2002 г. № 67-Ф3, ч.2-5 ст. 6 Федерального закона от 18 мая 2005 г. № 51 -Ф3. 
организацию и проведение выборов в Российской Федерации, может быть представлена следующим образом:

- указы Президента Российской Федерации;

- постановления Правительства Российской Федерации;

- нормативные правовые акты руководителей высших органов исполнительной власти субъектов Российской Федерации;

- нормативные правовые акты избирательных комиссий.

Рассмотрим данную систему нормативных правовых актов.

В соответствии с Конституцией Российской Федерации выборы депутатов Государственной Думы Федерального Собрания Российской Федерации нового созыва назначает Президент Российской Федерации ${ }^{1}$ При роспуске Государственной Думы Президент Российской Федерации одновременно назначает досрочные выборы депутатов Государственной Думы Федерального Собрания Российской Федерации нового созыва. Упомянутые решения принимаются Президентом Российской Федерации в форме указов.

Согласно пункту 4 статьи 11 Федерального закона от 12 июня 2002 г. № 67 Ф3 Президент Российской Федерации может осуществлять правовое регулирование выборов в орган государственной власти субъекта Российской Федерации, в орган местного самоуправления, если соответствующий закон субъекта Российской Федерации о выборах отсутствует либо положение закона субъекта Российской Федерации не может быть применено вследствие признания его судом недействующим и не подлежащим применению².

Важное значение в регулировании вопросов координации действий организаторов выборов, правоохранительных и иных государственных органов и учреждений в избирательном процессе принадлежит постановлениям Правительства Российской Федерации от 25 августа 1999 г. № 937 «О содействии избирательным комиссиям в организации подготовки и проведения выборов

\footnotetext{
1 См.: Указ Президента Российской Федерации от 2 сентября 2003 г. № 1030 «О назначении выборов депутатов Государственной Думы Федерального Собрания Российской Федерации нового созыва» // Рос. газ. 2003. 3 сентября; Указ Президента Российской Федерации от 2 сентября 2007 г. № 1144 «О назначении выборов депутатов Государственной Думы Федерального Собрания Российской Федерации нового созыва» // Рос. газ. 2007. 5 сентября.

2 См. Указ Президента Российской Федерации от 17 сентября 1995 г. № 951 «О выборах в органы государственной власти субъектов Российской Федерации и органы местного самоуправления» // Рос. газ. 1995. 23 сентября; Указ Президента Российской Федерации от 2 марта 1996 г. № 315 «О порядке переноса срока выборов в законодательные (представительные) органы государственной власти субъектов Российской Федерации» // С3 РФ. 1996. № 11. Ст. 1024.
} 
депутатов Государственной Думы Федерального Собрания Российской Федерации», от 13 января 2000 г. № 32 «О содействии избирательным комиссиям в организации подготовки и проведения выборов Президента Российской Федерации», от 5 сентября 2003 г. № 555 «О мерах по содействию избирательным комиссиям в организации подготовки и проведения выборов депутатов Государственной Думы Федерального Собрания Российской Федерации и Президента Российской Федерации», от 17 сентября 2007 года № 589 «О мерах по оказанию содействия избирательным комиссиям в реализации их полномочий при подготовке и проведении выборов депутатов Государственной Думы Федерального Собрания Российской Федерации и Президента Российской Федерации» ${ }^{1}$.

В соответствии с пунктом 2 статьи 81 Федерального закона от 12 июня 2002 г. № 67-Ф3, Правительство Российской Федерации определяет форму и порядок изготовления справки для участия в голосовании, выдаваемой гражданам Российской Федерации, находящимся в местах содержания под стражей подозреваемых и обвиняемых. Согласно Постановлению Правительства Российской Федерации от 2 июля 2003 г. № 391 «О порядке выдачи гражданам Российской Федерации, находящимся в местах содержания под стражей подозреваемых и обвиняемых, справки для участия в выборах или в референдуме» форма такой справки определяется совместно Министерством юстиции Российской Федерации, МВД России, ФСБ России и Министерством обороны Российской Федерации ${ }^{2}$.

В системе подзаконные нормативных правовых актов о выборах особое место занимают нормативные акты руководителей высших органов исполнительной власти субъектов Российской Федерации. Отличительной чертой данных нормативных актов, как правило, является непосредственное регулирование вопросов, связанных с участием субъектов Российской Федерации в защите конституционного строя в избирательном процессе. В частности, в большинстве субъектов Российской Федерации (Республика Хакасия, Удмуртская

\footnotetext{
${ }^{1}$ Содержание данных нормативных правовых актов рассматривается в параграфе 2.3.

${ }^{2}$ См. Постановление Правительства Российской Федерации от 2 июля 2003 г. № 391 «О порядке выдачи гражданам Российской Федерации, находящимся в местах содержания под стражей подозреваемых и обвиняемых, справки для участия в выборах или в референдуме» // СЗ РФ. 2003. № 27 (ч. 2). Ст. 2812.
} 
Республика, Ростовская, Нижегородская, Рязанская, Костромская области и др.) на уровне руководителей высших органов исполнительной власти приняты соответствующие постановления о содействии избирательным комиссиям в организации и проведении выборов, устанавливающие организационные основы взаимодействия комиссий субъектов Российской Федерации с правоохранительными органами ${ }^{1}$.

Источником избирательного права являются нормативные правовые акты избирательных комиссий².

Компетенция Центральной избирательной комиссии Российской Федерации по изданию нормативных правовых актов носит ограниченный характер и, как правило, прямо предусмотрена в соответствующих федеральных законах о выборах. Нормативные правовые акты ЦИК России содержат общеобязательные правила (нормы права), рассчитаны на множество типичных ситуаций и регулируют общественные отношения, связанные с выборами органов государственной власти и органов местного самоуправления. Как правило, нормативные правовые акты ЦИК России являются временными, т.е. распространяют свое действие на период конкретных федеральных избирательных кампаний.

Разновидностью нормативных правовых актов ЦИК России являются соглашения, касающиеся взаимодействия избирательных комиссий с другими государственными органами в процессе организации и проведения выборов. Примерами подобных нормативных правовых документов следует считать Соглашение о взаимодействии Центральной избирательной комиссии Российской Федерации и Министерства внутренних дел Российской Федерации от 21 февраля 2005 г., Соглашение между Центральной избирательной комиссией Российской

\footnotetext{
${ }^{1}$ См.: Постановление Правительства Республики Хакасия от 14 сентября 2005 г. № 288 «О мерах по содействию избирательным комиссиям в Республике Хакасия в организации подготовки и проведения выборов глав вновь образованных муниципальных образований и депутатов представительных органов муниципальных образований первого созыва в Республике Хакасия», Указ Президента Удмуртской Республики от 1 августа 2006 года № 113 «О содействии избирательным комиссиям в подготовке и проведении выборов депутатов представительных органов муниципальных районов» и др.

2 Анализ правовой природы актов ЦИК России и актов избирательных комиссий субъектов Российской Федерации дан в работах Ю.А. Дмитриева, С.А. Иванова, В.Б. Исраеляна. См.: Дмитриев Ю.А., Исраелян В.Б. Избирательное право и процесс в Российской Федерации. Ростов-на-Дону: Феникс, 2004. С. 769-774; Иванов C.A. Юридическая сила инструкций Центральной избирательной комиссии Российской Федерации и их место в правовой системе // Журнал российского права. 2006. № 7. С. 28-35.
} 
Федерации и Федеральной налоговой службой о взаимодействии и взаимном обмене информацией от 2 июля 2007 г. и др.

Специфика нормотворческой деятельности ЦИК России заключается в том, что согласно пункту 13 статьи 20 Федерального закона от 12 июня 2002 г. № 67Ф3, статье 6 Регламента Центральной избирательной комиссии Российской Федерации для вступления в силу нормативных актов ЦИК России их государственная регистрация не требуется ${ }^{1}$. Вместе с тем, большинство нормативных правовых актов ЦИК России и избирательных комиссий субъектов Российской Федерации прямо или косвенно затрагивает права и свободы граждан. В связи с этим процедура государственной регистрации могла бы способствовать не только повышению качества нормативных правовых актов избирательных комиссий, но и содействовать более полной реализации прав и свобод участников избирательного процесса.

Рассматривая нормотворчество избирательных комиссий, необходимо обозначить ряд существующих в данной сфере проблем.

Во-первых, федеральное избирательное законодательство не предусматривает права избирательных комиссий субъектов Российской Федерации принимать нормативные правовые акты по вопросам своей компетенции. При этом в специальном законодательном акте, регулирующем отношения, возникающие при использовании ГАС «Выборы» (статьи 7, 10 и 18 Федерального закона «О Государственной автоматизированной системе Российской Федерации «Выборы»), предусмотрены правомочия избирательных комиссий субъектов Российской Федерации издавать в пределах своей компетенции нормативные правовые акты по вопросам использования и эксплуатации ГАС «Выборы». В подпункте «и» пункта 10 статьи 23 Федерального закона от 12 июня 2002 г. № 67-Ф3 упоминается возможность избирательных комиссий субъектов Российской Федерации устанавливать по поручению ЦИК России нормативы, в соответствии с которыми изготавливаются

\footnotetext{
${ }^{1}$ По мнению некоторых ученых-юристов, изъятие нормативных правовых актов избирательных комиссий из процедуры государственной регистрации является продолжением принципа независимости от органов государственной власти, в частности, от Министерства юстиции Российской Федерации. См.: Волков В.П., Дамаскин O.В., Шапиев С.M. Некоторые проблемы и пути их решения для обеспечения законности избирательного процесса в Российской Федерации. М.: РЦОИТ, 2009. С. 36.
} 
списки избирателей и другие избирательные документы. Таким образом, нормотворческая деятельность, осуществляемая избирательными комиссиями на региональном уровне, не регулируется в должной мере действующим федеральным законодательством ${ }^{1}$. Между тем, региональный фрагмент нормативного правового регулирования выборов, представленный нормативными правовыми актами избирательных комиссий субъектов Российской Федерации по предмету своего ведения, является необходимым элементом избирательного законодательства субъектов Российской Федерации о выборах. Поэтому нормотворческие полномочия избирательных комиссий субъектов Российской Федерации должны быть законодательно закреплены.

Во-вторых, в избирательном законодательстве и Регламенте Центральной избирательной комиссии Российской Федерации отсутствует перечень видов нормативных правовых актов, которые может принимать Центральная избирательная комиссия Российской Федерации. В указанных документах из числа нормативных правовых актов, принимаемых ЦИК России, упоминаются только инструкции ${ }^{2}$. При этом нормативный правовой характер, кроме инструкций Центральной избирательной комиссии, носят положения, регламенты и соглашения.

Думается, что этот пробел правового регулирования требует восполнения. Кроме того, учитывая особенный статус избирательных комиссий в механизме государства, обозначенная проблема актуализирует вопрос принятия Федерального закона «О нормативных правовых актах в Российской Федерации».

\section{3. Содержание конституционно-правовой регламентации стадий избирательного процесса в интересах защиты конституционного строя России}

Рассмотрев понятие, содержание и систему актов нормативного правового регулирования организации и проведения выборов в Российской Федерации,

\footnotetext{
${ }^{1}$ См.: Дмитриев Ю.А., Исраелян В.Б. Избирательное право и процесс в Российской Федерации. Ростов-наДону: Феникс, 2004. С. 771-772.

${ }^{2}$ См. также Иванов С.A. Юридическая сила инструкций Центральной избирательной комиссии Российской Федерации и их место в правовой системе // Журнал российского права. 2006. № 7. С. 28-35.
} 
остановимся подробней на изучении избирательного процесса с позиций защиты конституционного строя.

Целями конституционно-правовой регламентации избирательного процесса в интересах защиты конституционного строя России являются: обеспечение легитимности формирования органов государственной власти и органов местного самоуправления на основе законности прохождения избирательного процесса, а также защита демократических принципов и норм избирательного права.

Достижение целей конституционно-правовой регламентации избирательного процесса в интересах защиты конституционного строя России связано с решением следующих задач:

- законодательное закрепление гарантий свободного волеизъявления граждан на выборах, развития политического и идеологического плюрализма, совершенствования общественного контроля организации и проведения выборов;

- юридическое обеспечение предупреждения и пресечения возможных противоправных действий участников выборов и иных лиц, вмешательства организованных преступных групп, экстремистских организаций и отдельных лиц, представителей иностранных спецслужб и организаций в избирательный процесс;

- совершенствование нормативной правовой базы, регулирующей общественные отношения в области защиты конституционного строя в избирательном процессе.

Анализ правовых норм, регламентирующих стадии избирательного процесса в интересах защиты конституционного строя России, свидетельствует о том, что данные нормы содержат гарантии законности прохождения избирательного процесса, устанавливают юридические механизмы предупреждения правонарушений в ходе избирательных кампаний, закрепляют правовой статус участников избирательного процесса и предусматривают контроль за их деятельностью. 
Проанализируем конкретные стадии избирательного процесса и их конституционно-правовую регламентацию в интересах защиты конституционного строя России.

Юридически избирательная кампания начинается с момента официального опубликования решения о назначении даты выборов. Назначение выборов связано с принципом их обязательности и периодичности. Правовую регламентацию данной стадии избирательного процесса следует рассматривать во взаимосвязи с содержанием части 4 статьи 3 Конституции Российской Федерации: «Никто не может присваивать власть в Российской Федерации. Захват власти или присвоение властных полномочий преследуются по федеральному закону» ${ }^{1}$.

Выборы назначают уполномоченные на то органы или должностные лица в зависимости от уровня выборов. Пунктом 9 статьи 10 Федерального закона от 12 июня 2002 г. № 67-Ф3 предусмотрена возможность вмешательства избирателей, избирательных объединений, органов государственной власти, органов местного самоуправления, прокурора в процесс назначения выборов. Суд общей юрисдикции может определить срок, не позднее которого уполномоченный орган или должностное лицо (в случае их отсутствия - соответствующая избирательная комиссия) должны назначить выборы. При этом суд также вправе возложить на Центральную избирательную комиссию Российской Федерации или избирательную комиссию субъекта Российской Федерации (соответственно уровню выборов) обязанность сформировать в 10-дневный срок со дня вступления в силу решения суда временную избирательную комиссию, а при отсутствии уполномоченного назначить выборы органа или должностного лица также установить срок, в течение которого временная избирательная комиссия должна назначить выборы.

Закрепление правовых норм, гарантирующих назначение выборов (статья 5 Федерального закона от 10 января 2003 г. № 19-Ф3, статья 6 Федерального закона от 18 мая 2005 г. № 51-Ф3, статья 10 Федерального закона от 12 июня 2002 г. № 67-Ф3), имеет важное значение для защиты конституционного строя, поскольку

\footnotetext{
1 См. Ст. 278 Уголовного кодекса Российской Федерации «Насильственный захват власти или насильственное удержание власти».
} 
позволяет не допустить узурпации политической власти со стороны выборных должностных лиц и депутатов федерального, регионального и местного уровней ${ }^{1}$.

Важной стадией избирательного процесса является составление списков избирателей. Список избирателей составляется с использованием Государственной автоматизированной системы Российской Федерации «Выборы». Помимо непосредственного обеспечения избирательных действий, сбор, систематизация и использование сведений об избирателях в процессе организации и проведения выборов позволяют компетентным государственным органам принимать меры по выявлению лиц, подозреваемых в совершении преступлений и скрывающихся от органов дознания, следствия и суда либо проживающих по подложным или поддельным документам, а также производить розыск объектов оперативной заинтересованности.

В соответствии с пунктом 5 статьи 17 Федерального закона от 12 июня 2002 г. № 67-Ф3 при выборах в органы местного самоуправления в списки избирателей не включаются военнослужащие, проходящие военную службу по призыву в воинских частях, военных организациях и учреждениях, которые расположены на территории соответствующего муниципального образования, если место жительства этих военнослужащих до призыва на военную службу не было расположено на территории муниципального образования. Анализируемое законодательное ограничение на включение граждан - военнослужащих в списки избирателей фактически лишает данную категорию российских граждан активного избирательного права ${ }^{2}$. К военнослужащим, проходящим военную службу по призыву, относятся не только лица, проходящие службу в воинских частях, но и курсанты (слушатели) военных образовательных учреждений первого года обучения. Таким образом, курсанты (слушатели) военных учебных заведений первого года обучения также лишены права участвовать в муниципальных

\footnotetext{
${ }^{1}$ См. также Иванченко А.В., Прудникова Т.A. Конституционно-правовые гарантии от монополизации власти // Вестник Московского университета МВД России. 2004. № 2. С. 36-39.

2 Проблемы реализации избирательных прав военнослужащих исследованы в работах Ю.С. Леньшиной и В.А. Мишенина. См.: Леньшина Ю.С. Проблемы реализации активного и пассивного избирательного права военнослужащих Вооруженных Сил России и направления совершенствования законодательства Российской Федерации // «Черные дыры» в российском законодательстве. 2007. № 4. С. 49-50; Леньшина Ю.С. Активное и пассивное избирательное право военнослужащих Вооруженных Сил России: проблемы реализации и пути совершенствования законодательства Российской Федерации на современном этапе // Военно-юридический журнал. 2008. № 3. С. 24-25; Мишенин B.A. Актуальные вопросы обеспечения активного избирательного права военнослужащих-курсантов в период проведения выборов в органы местного самоуправления // Военное право в XXI веке. Серия «Право в Вооруженных Силах - консультант». Вып. 73. М., 2007. С. 284-287.
} 
выборах. Тем самым законодательство о выборах нарушает равенство конституционных прав студентов и лиц, обучающихся в военных образовательных учреждениях. Наличие подобного ограничения не связано с защитой публичных интересов, перечисленных в части 3 статьи 55 Конституции, и является чрезмерным.

Пункт 18 статьи 17 Федерального закона от 12 июня 2002 г. № 67-Ф3, пункт 12 статьи 27 Федерального закона от 10 января 2003 г. № 19-Ф3, часть 12 статьи 16 Федерального закона от 18 мая 2005 г. № 51-Ф3 устанавливают правило, согласно которому вносить какие-либо изменения в списки избирателей после окончания голосования и начала подсчета голосов избирателей запрещается. Данная норма направлена на недопущение возможных злоупотреблений, связанных с фальсификацией избирательных документов и итогов голосования членами избирательных комиссий.

Для организации и проведения выборов важным является нормативное правовое регулирование образования избирательных округов и избирательных участков. Это обусловлено тем, что возможные манипуляции представителей преступных групп, экстремистских сил, коррумпированных должностных лиц избирательных комиссий, депутатов представительных органов государственной власти и местного самоуправления при образовании избирательных округов могут серьезно исказить картину свободного волеизъявления избирателей, дискредитировать демократические принципы и нормы избирательного права, и тем самым причинять ущерб конституционному строю России.

Правовой базой предупреждения подобных правонарушений служит Федеральный закон от 12 июня 2002 г. № 67-Ф3 (статья 18) и Федеральный закон от 18 мая 2005 г. № 51-Ф3 (статья 12)ํ․

В данных законодательных актах сформулированы требования к образованию избирательных округов:

а) соблюдение примерного равенства одномандатных избирательных округов по числу избирателей, примерного равенства числа избирателей на один депутатский мандат при образовании многомандатных избирательных округов.

\footnotetext{
${ }^{1}$ См.: Князев С.Д. Правовой режим образования избирательных округов: законодательство и судебная практика // Российский юридический журнал. 2008. № 3. С. 14-21.
} 
б) перечень труднодоступных и отдаленных местностей устанавливается законом субъекта Российской Федерации, вступившим в силу до дня официального опубликования решения о назначении выборов.

в) на определенных законом субъекта Российской Федерации территориях компактного проживания коренных малочисленных народов допустимое отклонение от средней нормы представительства избирателей в соответствии с законом субъекта Российской Федерации не должно составлять более 40 процентов;

г) не допускается образование избирательного округа из территорий, не граничащих между собой, за исключением анклавных территорий.

Нормативное правовое регулирование образования избирательных округов и формирования избирательных участков направлено на недопущение возможных манипуляций представителей преступных групп, экстремистских сил, коррумпированных должностных лиц избирательных комиссий, депутатов представительных органов государственной власти и местного самоуправления в условиях формирования территориальной основы организации и проведения выборов.

Наряду с образованием избирательных округов и участков, большое значение в избирательном процессе имеет формирование избирательных комиссий. Комиссиям принадлежит главная роль в организации выборов. Их система, правовой статус, порядок формирования определяются главой IV Федерального закона от 12 июня 2002 г. № 67-Ф3, главой II Федерального закона от 10 января 2003 г. № 19-Ф3, главой III Федерального закона от 18 мая 2005 г. № 51-Ф3. Элементом характеристики правосубъектности избирательных комиссий являются требования к членам комиссий, соответствие которым предоставляет лицу право занимать эту должность.

В соответствии со ст. 29 Федерального закона от 12 июня 2002 г. № 67-Ф3 членами избирательных комиссий с правом решающего голоса не могут быть:

- лица, не имеющие гражданства Российской Федерации, а также граждане Российской Федерации, имеющие гражданство иностранного государства либо вид на жительство или иной документ, подтверждающий право на постоянное 
проживание гражданина Российской Федерации на территории иностранного государства ${ }^{1}$;

- граждане Российской Федерации, признанные решением суда, вступившим в законную силу, недееспособными или ограниченно дееспособными;

- граждане Российской Федерации, не достигшие возраста 18 лет;

- депутаты законодательных органов государственной власти, органов местного самоуправления;

- выборные должностные лица, а также высшие должностные лица субъектов Российской Федерации, главы местных администраций;

- судьи, прокуроры;

- кандидаты, их уполномоченные представители и доверенные лица, уполномоченные представители и доверенные лица политических партий, выдвинувших кандидатов;

- супруги и близкие родственники кандидатов, близкие родственники супругов кандидатов;

• лица, которые находятся в непосредственном подчинении у кандидатов;

- члены комиссий с правом совещательного голоса;

- лица, выведенные из состава комиссий по решению суда, а также лица, утратившие свои полномочия членов комиссии с правом решающего голоса в результате расформирования комиссии (за исключением лиц, в отношении которых судом было установлено отсутствие вины за допущенные комиссией нарушения), - в течение пяти лет со дня вступления в законную силу соответствующего решения суда;

122 июня 2010 г. Конституционный Суд Российской Федерации по жалобе Малицкого А.М. признал неконституционными положения подпункта «а» пункта 1 и подпункта «а» пункта 8 статьи 29 Федерального закона «Об основных гарантиях избирательных прав и права на участие в референдуме граждан Российской Федерации», согласно которым граждане России, имеющие вид на жительство иностранного государства, не могут быть членами территориальных избирательных комиссий с правом решающего голоса. По мнению Конституционного Суда, участие гражданина Российской Федерации, обладающего видом на жительство на территории иностранного государства, в деятельности территориальной избирательной комиссии в качестве члена с правом решающего голоса не представляет угрозы основам конституционного строя, нравственности, здоровью, правам и законным интересам других лиц, обеспечению обороны страны и безопасности государства, не ставит под сомнение способность такого гражданина независимо, беспристрастно и с соблюдением требований закона осуществлять полномочия члена избирательной комиссии. 
- лица, имеющие неснятую и непогашенную судимость, а также лица, подвергнутые в судебном порядке административному наказанию за нарушения законодательства о выборах, - в течение одного года со дня вступления в законную силу решения (постановления) суда о назначении административного наказания.

Указанные правовые положения направлены на противодействие попыткам ряда иностранных государств и российских организованных преступных групп использовать возможности избирательного процесса для нанесения ущерба конституционному строю России, на обеспечение независимости избирательных комиссий от кандидатов и административного ресурса должностных лиц органов государственной власти и органов местного самоуправления ${ }^{1}$.

Ограничения, связанные с отсутствием гражданства Российской Федерации, наличием гражданства иностранного государства либо вида на жительство или иного документа, подтверждающего право на постоянное проживание гражданина Российской Федерации на территории иностранного государства, распространяются и на членов комиссий с правом совещательного голоса. При этом в перечень должностных лиц, которые не могут быть членами комиссии с правом совещательного голоса, помимо депутатов представительных органов, выборных должностных лиц, высших должностных лиц субъектов Российской Федерации, глав местных администраций, судей и прокуроров, входят лица, замещающие командные должности в воинских частях, военных организациях и учреждениях, а также работники аппаратов избирательных комиссий.

В целях повышения уровня независимости избирательных комиссий, противодействия коррупции среди руководителей и работников избирательных комиссий, уменьшения влияния на комиссии со стороны представителей иностранных государств, международных и иностранных организаций Федеральным законом от 25 декабря 2008 г. № 274-Ф3 в Федеральный закон от 12 июня 2002 г. № 67-Ф3 введен пункт 15.1, установивший ряд дополнительных ограничений в деятельности членов комиссий, работающих на постоянной

\footnotetext{
${ }^{1}$ См. также Добровольский П.Е. Персональная независимость избирательных комиссий муниципальных образований / Сб. науч. трудов. Гуманитарные науки. Вып. 26. Сургут, 2007. С. 138-143; Добровольский П.Е. О независимости избирательных комиссий муниципальных образований // Административное и муниципальное право. 2008. № 10. С. 10-20.
} 
основе. В число таких ограничений вошли: запрет на вхождение в состав органов управления, попечительских или наблюдательных советов действующих на территории России иностранных некоммерческих неправительственных организаций и их структурных подразделений; запрет получения вознаграждений от физических и юридических лиц в связи с выполнением должностных обязанностей; запрет выезда за счет средств физических и юридических лиц за пределы территории России в связи с выполнением должностных обязанностей; запрет нецелевого использования средств материально-технического, финансового и информационного обеспечения, предназначенных для служебной деятельности; запрет разглашения или использования в неслужебных целях сведений ограниченного доступа или служебной информации.

Нужно отметить, что избирательные комиссии наделены существенными правомочиями в рамках реализации своих основных функций: обеспечения реализации избирательных прав граждан, обеспечения защиты избирательных прав граждан, осуществления контроля за соблюдением избирательных прав граждан. В частности, они наделены полномочиями требовать от государственных органов, органов местного самоуправления, учреждений, организаций, предприятий с государственным участием, а также их должностных лиц представления ответов на вопросы, связанные с проведением избирательной кампании, обращаться за помощью в целях устранения выявленных нарушений прав граждан в суды, правоохранительные органы. Могут они и отменять незаконные решения нижестоящих комиссий.

Важнейшей гарантией достоверности и гласности проведения выборов является участие наблюдателей в избирательных кампаниях. Правовой статус наблюдателей конкретизирован в федеральных законах о выборах и интерпретационных актах ЦИК России.

Наблюдателями не могут быть выборные должностные лица, депутаты, высшие должностные лица субъектов Российской Федерации, главы местных администраций, лица, находящиеся в их непосредственном подчинении, судьи, прокуроры, члены избирательных комиссий с правом решающего голоса (Пункт 4 
статьи 30 Федерального закона от 12 июня 2002 г. № 67-Ф3, пункт 8 статьи 23 Федерального закона от 10 января 2003 г. № 19-Ф3, часть 2 статьи 30 Федерального закона от 18 мая 2005 г. № 51-Ф3). Законодатель использует данный запрет для того, чтобы не допустить использования указанными должностными лицами «административного ресурса», т.е. преимуществ своего должностного положения и возможностей влиять на избирателей и на членов избирательных комиссий в день голосования, в том числе, при подсчете голосов ${ }^{1}$.

С обеспечением защиты конституционного строя в избирательном процессе тесно связан вопрос о деятельности иностранных (международных) наблюдателей и представителей иностранных средств массовой информации ${ }^{2}$. Нужно подчеркнуть, что российское законодательство регламентирует правовой статус иностранных (международных) наблюдателей, их права и обязанности (статья 24 Федерального закона от 10 января 2003 г. № 19-Ф3, статья 31 Федерального закона от 18 мая 2005 г. № 51-Ф3).

Для иностранных граждан порядок въезда и пребывания в Российской Федерации регулируется Федеральным законом «О порядке выезда из Российской Федерации и въезда в Российскую Федерацию», при этом иностранные (международные) наблюдатели из числа граждан иностранных государств передвигаются по территории Российской Федерации с учетом ограничений, установленных Федеральным законом «О правовом положении иностранных граждан в Российской Федерации». Часть 2 статьи 4 Закона Российской Федерации от 14 июля 1992 г. (в ред. от 27 декабря 2009 г.) «О закрытом административно-территориальном образовании», пункт 25 Положения об обеспечении особого режима в закрытом административно-территориальном образовании, на территории которого расположены объекты Министерства обороны Российской Федерации, утвержденного Постановлением Правительства

\footnotetext{
${ }^{1}$ См.: Пустошинская О.С. Административный ресурс в избирательном процессе: вопросы правовой оценки и регулирования / Особенности реализации избирательного законодательства на современном этапе. Материалы Всероссийской научно-практической конференции. Тюмень, 2007. С. 142-145; Зырянова В. Требования к кандидатуре национального наблюдателя в российском избирательном процессе / Дни науки - 2008. Материалы научно-практической конференции. Иркутск, 2008. С. 215-216.

2 См.: Новолихина Ю.Ю. Участие международных наблюдателей в избирательном процессе / Проблемы гармонизации публичных и частных интересов в избирательном праве. Материалы III Всероссийской научнопрактической конференции. Самара: изд-во Самар. ун-та, 2008. С. 149-153.
} 
Российской Федерации от 26 июня 1998 г. (в ред. от 23 декабря 2009 г.) № 655, пункт 26 Положения об обеспечении особого режима в закрытом административно-территориальном образовании, на территории которого расположены объекты Государственной корпорации по атомной энергии «Росатом», утвержденного Постановлением Правительства Российской Федерации от 11 июня 1996 г. (в ред. от 22 апреля 2009 г.) № 693 устанавливают, что въезд на территорию закрытого административно-территориального образования иностранных граждан и выезд из него осуществляется по согласованию с органами федеральной службы безопасности по месту нахождения закрытого образования. Иными словами, закрепляется разрешительный характер посещения указанных территорий. Кроме того, в соответствии с пунктом 2 Постановления Правительства Российской Федерации «Об утверждении перечня территорий Российской Федерации с регламентированным посещением для иностранных граждан» от 4 июля 1992 года (в ред. от 23 декабря 2009 г.) № 470 Министерство безопасности Российской Федерации (ныне - ФСБ России) или его органы на местах принимают решение о допуске иностранных граждан для посещения этих территорий по согласованию с заинтересованными министерствами и ведомствами или их территориальными органами.

Пункт 2.2 части 2 статьи 3 Закона Российской Федерации «О закрытом административно-территориальном образовании» определяет, что на территории закрытого административно-территориального образования не допускается деятельность международных организаций (объединений), что исключает возможность мониторинговой деятельности международных наблюдателей международных организаций в закрытых административно-территориальных образованиях.

Свободное посещение избирательных участков (участков референдума) и помещений для голосования международными наблюдателями невозможно и в пограничных зонах. На основании статьи 17 Закона Российской Федерации от 1 апреля 1993 г. (в ред. от 30 декабря 2008 г.) № 4730-1 «О государственной 
границе Российской Федерации» устанавливаются места въезда (прохода) в пограничную зону, могут определяться время въезда (прохода), маршруты передвижения, продолжительность и иные условия пребывания в пограничной зоне лиц и транспортных средств.

Вместе с тем, законодательство о выборах позволяет иностранным (международным) наблюдателям и представителям иностранных средств массовой информации присутствовать в помещениях для голосования на отдельных категориях избирательных участков, доступ в которые не всегда является свободным (воинские части, закрытые административнотерриториальные образования, пограничные зоны). Таким образом, имеет место коллизия между Федеральным законом «О правовом положении иностранных граждан в Российской Федерации», Законом Российской Федерации «О закрытом административно-территориальном образовании», Законом Российской Федерации «О государственной границе Российской Федерации» и федеральными законами о выборах, которая создает угрозу конституционному строю и безопасности государства.

Выдвижение кандидатов (списков кандидатов) регулируется главой V Федерального закона от 12 июня 2002 г. № 67-Ф3, главой V Федерального закона от 10 января 2003 г. № 19-Ф3, главой VI Федерального закона от 18 мая 2005 г. № 51-Ф3. Законодательством предусмотрены различные способы выдвижения кандидатов (непосредственное выдвижение либо выдвижение в составе списка кандидатов). Непосредственное выдвижение кандидатов может быть осуществлено путем самовыдвижения и выдвижения избирательным объединением. В составе списка кандидат может быть выдвинут только избирательным объединением.

Действующее законодательство не предусматривает права выдвижения кандидатов избирателями и группами избирателей. Исключение составляет пункт 2 статьи 34 Федерального закона от 10 января 2003 г. № 19-Ф3, который определяет необходимость поддержки самовыдвижения кандидата на должность Президента Российской Федерации группой избирателей в количестве не менее 
500 граждан Российской Федерации, обладающих активным избирательным правом. Думается, что лишение избирателей, не являющихся членами политических партий, права самовыдвижения кандидатами на выборах в Государственную Думу Федерального Собрания Российской Федерации, нарушило равенство политических прав партийных и беспартийных граждан Российской Федерации. Решение о выдвижении граждан, не являющихся членами политической партии, зависит от усмотрения руководства политической партии и не предусматривает возможности обжалования, что можно рассматривать как косвенное ограничение пассивного избирательного права беспартийных граждан Российской Федерации. Согласно подпункту «в» пункта 8 Методики проведения экспертизы проектов нормативных правовых актов и иных документов в целях выявления в них положений, способствующих созданию условий для проявления коррупции, утвержденной Постановлением Правительства Российской Федерации от 5 марта 2009 г. № 196, наличие завышенных требований к лицу, предъявляемых для реализации принадлежащего ему права, является коррупционным фактором ${ }^{1}$.

Требования к кандидатам на выборах в органы государственной власти и органы местного самоуправления устанавливаются Конституцией и Федеральными законами от 12 июня 2002 г. № 67-Ф3, от 10 января 2003 г. № 19Ф3, от 18 мая 2005 г. № 51-Ф3.

Согласно части 3 статьи 32 Конституции Российской Федерации не обладают активным и пассивным избирательным правом граждане, признанные судом недееспособными или содержащиеся в местах лишения свободы по приговору суда.

В соответствии с пунктом 3.1 статьи 4 Федерального закона от 12 июня 2002 г. № 67-Ф3 не имеют права быть избранными граждане Российской Федерации, имеющие гражданство иностранного государства либо вид на жительство или иной документ, подтверждающий право на постоянное

\footnotetext{
${ }^{1}$ См. СЗ РФ. 2009. № 10. Ст. 1241.
} 
проживание гражданина Российской Федерации на территории иностранного государства ${ }^{1}$.

Аналогичные ограничения для кандидатов, связанные с наличием гражданства иностранного государства либо вида на жительство или иного документа, подтверждающего право на постоянное проживание гражданина Российской Федерации на территории иностранного государства, закреплены в пункте 5.1 статьи 3 Федерального закона от 10 января 2003 г. № 19-Ф3) ${ }^{2}$ и статье 5 Федерального закона от 18 мая 2005 г. № 51-Ф3.

В соответствии с пунктом 3.2 статьи 4 Федерального закона от 12 июня 2002 г. № 67-Ф3:

«Не имеют права быть избранными граждане Российской Федерации:

а) осужденные к лишению свободы за совершение тяжких и (или) особо тяжких преступлений и имеющие на день голосования на выборах неснятую и непогашенную судимость за указанные преступления;

б) осужденные за совершение преступлений экстремистской направленности, предусмотренных Уголовным кодексом Российской Федерации, и имеющие на день голосования на выборах неснятую и непогашенную судимость за указанные преступления ${ }^{3}$;

в) подвергнутые административному наказанию за совершение административного правонарушения, предусмотренного статьей 20.3 и 20.29 Кодекса Российской Федерации об административных правонарушениях, если голосование на выборах состоится до окончания срока, в течение которого лицо считается подвергнутым административному наказанию;

\footnotetext{
${ }^{1}$ Указанные граждане вправе быть избранными в органы местного самоуправления, если это предусмотрено международным договором Российской Федерации. Об ограничении пассивного избирательного права в связи с наличием гражданства иностранного государства См. Мишунина А.А. Ограничение прав иностранных граждан и лиц без гражданства в избирательной сфере / Особенности реализации избирательного законодательства на современном этапе. Материалы Всерос. науч.-практ. конф. Тюмень: Изд-во Вектор Бук, 2007. С. 233-236.

2 См. Решение Верховного Суда Российской Федерации от 28 декабря 2007 года по заявлению В.К. Буковского об отмене постановления Центральной избирательной комиссии Российской Федерации от 22 декабря 2007 г. № 80/644-5 «Об отказе в регистрации группы избирателей, созданной для поддержки самовыдвижения Буковского В.К. кандидатом на должность Президента Российской Федерации, и ее уполномоченных представителей».

3 Преступления экстремистской направленности указаны в статье 282.1 Уголовного кодекса Российской Федерации. К ним относятся совершенные по мотивам идеологической, политической, расовой, национальной или религиозной ненависти либо вражды, а равно по мотивам ненависти либо вражды в отношении какой-либо социальной группы преступления, предусмотренные статьями 148, 149, частями 1 и 2 статьи 213, статьями 214, 243, 244, 280 и 282 Уголовного кодекса Российской Федерации.
} 
г) в отношении которых вступившим в силу решением суда установлен факт нарушения ограничений, предусмотренных пунктом 1 статьи 56 настоящего Федерального закона, либо совершения действий, предусмотренных подпунктом «ж» пункта 7 и подпунктом «ж» пункта 8 статьи 76 настоящего Федерального закона, если указанные нарушения либо действия совершены до дня голосования на выборах в течение установленного законом срока полномочий органа государственной власти или органа местного самоуправления, в которые назначены выборы, либо должностного лица, для избрания которого назначены выборы».

Конституционность отдельных ограничений прав и свобод человека и гражданина закреплена в ряде решений Конституционного Суда Российской Федерации. Суть этих правовых позиций заключается в следующем

- ограничения конституционных прав должны быть необходимыми и соразмерными конституционно признаваемым целям таких ограничений;

- в тех случаях, когда конституционные нормы позволяют законодателю установить ограничения закрепляемых ими прав, он не может осуществлять такое регулирование, которое посягало бы на само существо того или иного права и приводило бы к утрате его реального содержания;

- при допустимости ограничения того или иного права в соответствии с конституционно одобряемыми целями государство, обеспечивая баланс конституционно защищаемых ценностей и интересов, должно использовать не чрезмерные, а только необходимые и строго обусловленные этими целями меры;

- норма Конституции о возможности ограничения прав и свобод, при определенных условиях, не может служить оправданием ущемления прав и свобод человека и гражданина в зависимости от национальной принадлежности или иного обстоятельства;

\footnotetext{
${ }^{1}$ См. Доклад Председателя Конституционного Суда Российской Федерации В.Д. Зорькина «Национальные интересы, современный миропорядок и конституционная законность» на научно-практической конференции «Роль права в обеспечении национальных интересов» 25 октября 2005 г. //http://www.ksrf.ru/News/Speech/Pages/ViewItem. Asph?ParamId=15; См. также Зорькин В.Д. Угрозы международной и национальной безопасности и ограничение прав человека в практике конституционного правосудия // Российское правосудие. 2006. № 2. С. 3-13.
} 
- публичные интересы, перечисленные в части 3 статьи 55 Конституции Российской Федерации, могут оправдать правовые ограничения прав и свобод, только если такие ограничения отвечают требованиям справедливости, являются адекватными, пропорциональными, соразмерными и необходимыми для защиты конституционно значимых ценностей, в том числе прав и законных интересов других лиц, не имеют обратной силы и не затрагивают само существо конституционного права, т.е. не ограничивают пределы и применение основного содержания соответствующих конституционных норм;

- чтобы исключить возможность несоразмерного ограничения прав и свобод человека и гражданина в конкретной правоприменительной ситуации, норма должна быть формально определенной, точной, четкой и ясной, не допускающей расширительного толкования установленных ограничений и, следовательно, произвольного их применения.

Законодательство о выборах устанавливает две группы дополнительных ограничений пассивного избирательного права: ограничения, связанные $c$ выдвижением кандидатов (списков кандидатов), и ограничения, связанные с регистрацичей кандидатов (списков кандидатов).

Ограничения, связанные с выдвижением кандидатов, установлены пунктами 4-7 статьи 32 Федерального закона от 12 июня 2002 г. № 67-Ф3. Гражданин Российской Федерации, замещавший должность Президента Российской Федерации и досрочно прекративший исполнение полномочий Президента Российской Федерации в случае отставки, стойкой неспособности по состоянию здоровья осуществлять принадлежащие ему полномочия или отрешения от должности, не может быть выдвинут кандидатом на выборах, назначенных в связи с указанными обстоятельствами. Гражданин Российской Федерации, замещавший должность главы муниципального образования и ушедший с указанной должности в отставку по собственному желанию, в том числе в связи с избранием его депутатом либо на иную выборную должность, замещение которой несовместимо со статусом главы муниципального образования, либо отрешенный от должности главы муниципального образования высшим должностным лицом субъекта Российской Федерации (руководителем 
высшего исполнительного органа государственной власти субъекта Российской Федерации), не может быть выдвинут кандидатом на выборах, назначенных в связи с указанными обстоятельствами. При проведении повторных и дополнительных выборов для замещения вакантного депутатского мандата в действующем законодательном органе государственной власти, представительном органе местного самоуправления не может быть выдвинуто кандидатом лицо, являющееся депутатом (членом) этого органа. Комментируемые пункты устанавливают ограничения пассивного избирательного права для граждан, замещающих некоторые государственные и муниципальные должности, при проведении выборов на эти должности и создают заслон злоупотреблению так называемым «административным ресурсом» в условиях избирательного процесса.

В пункте 7 статьи 4 Федерального закона от 12 июня 2002 г. № 67-Ф3 закреплено ограничение на регистрацию кандидатов: «При наличии в отношении гражданина Российской Федерации вступившего в силу решения суда о лишении его права занимать государственные и (или) муниципальные должности в течение определенного срока этот гражданин не может быть зарегистрирован в качестве кандидата, если голосование на выборах в органы государственной власти, органы местного самоуправления состоится до истечения указанного срока».

Кроме того, пунктом 6 статьи 3 Федерального закона от 10 января 2003 г. № 19-Ф3 установлено: «Гражданин Российской Федерации, в отношении которого вступил в силу приговор суда о лишении его права занимать государственные должности в течение определенного срока, если такое наказание предусмотрено федеральным законом, не может быть зарегистрирован в качестве кандидата на должность Президента Российской Федерации, если голосование на выборах Президента Российской Федерации состоится до истечения установленного судом срока».

Аналогичным образом данное ограничение закреплено в пункте 5 статьи 5 Федерального закона от 18 мая 2005 г. № 51-Ф3: «Гражданин Российской Федерации, в отношении которого вступил в законную силу приговор суда о лишении его права занимать государственные должности в течение 
определенного срока, не может быть зарегистрирован в качестве кандидата на выборах депутатов Государственной Думы, если голосование на выборах состоится до истечения установленного судом срока».

В целях недопущения выдвижения и регистрации в качестве кандидатов на выборные должности лиц, находящихся в уголовном розыске, пункт 5 статьи 33 Федерального закона от 12 июня 2002 г. № 67-Ф3, пункт 10 статьи 34 Федерального закона от 10 января 2003 г. № 19-Ф3, предписывают кандидата лично подавать документы при его регистрации соответствующей избирательной комиссией.

Согласно пункту 4 статьи 61, пункту 7 статьи 63, пункту 9 статьи 37 Федерального закона от 12 июня 2002 г. № 67-Ф3; пункту 4 статьи 66, пункту 6 статьи 67, подпункту 3 пункта 6 статьи 34 Федерального закона от 10 января 2003 г. № 19-Ф3; части 4 статьи 72, части 6 статьи 73, части 4 статьи 38 Федерального закона от 18 мая 2005 г. № 51-Ф3 сведения о неснятой и непогашенной судимости кандидата должны указываться в подписном листе, на информационных стендах и в избирательных бюллетенях. Подпункт «з» пункта 7 статьи 76 Федерального закона от 12 июня 2002 г. № 67-Ф3 отмечает, что регистрация кандидата может быть отменена судом в случае установления факта сокрытия кандидатом сведений о своей неснятой (непогашенной) судимости ${ }^{1}$. Аналогичные санкции предусмотрены подпунктом 7 пункта 5 статьи 84 Федерального закона от 10 января 2003 г. № 19-Ф3 и подпунктом 4 части 9 статьи 91 Федерального закона от 18 мая 2005 г. № 51-Ф3. Данные правовые меры используются для предотвращения проникновения криминальных и экстремистских элементов в органы государственной власти и органы местного самоуправления в процессе выборов ${ }^{2}$.

1 Лица, имеющие снятую или погашенную судимость (судимости), в соответствии с действующим законодательством могут беспрепятственно избираться в органы государственной власти и местного самоуправления. См. Приложение.

2 См.: Франскевич М.П., Щедрин Н.В. Криминальное прошлое как основание ограничения пассивного избирательного права / Актуальные проблемы борьбы с преступностью в Сибирском регионе. Сб. материалов Международной научно-практической конференции. Ч.1. Красноярск, 2005. С. 300-303; Дуксин П.А. Лишение пассивного избирательного права лиц, подвергнутых мерам юридической ответственности за совершение действий экстремистской направленности / Проблемы политической и правовой науки. Вып. 1. Саратов:Изд-во Сарат. ун-та, 2007. C. 190-194. 
В соответствие с пунктом 6 статьи 4 Федерального закона от 12 июня 2002 г. № 67-Ф3 федеральным законом, конституцией (уставом), законом субъекта Российской Федерации могут устанавливаться дополнительные условия реализации гражданином Российской Федерации пассивного избирательного права, не позволяющие одному и тому же лицу занимать одну и ту же выборную должность более установленного количества сроков подряд ${ }^{1}$. Указанное нормативное предписание служит специальной гарантией от монополизации власти.

Конституционно-правовая регламентация выдвижения кандидата (списков кандидатов) в интересах защиты конституционного строя предусматривает: согласие кандидата баллотироваться по соответствующему избирательному округу с обязательством в случае его избрания прекратить деятельность, несовместимую со статусом депутата или с замещением иной выборной должности; представление расширенного перечня сведений с указанием не только данных об образовании, основном месте работы или службы, занимаемой должности (при их отсутствии - о роде занятий), но и сведений о размере и об источниках доходов кандидата (каждого кандидата из списка кандидатов), а также об имуществе, принадлежащем кандидату на праве собственности, о вкладах в банках и ценных бумагах, неснятых, непогашенных судимостях, гражданстве иностранного государства; письменное уведомление избирательной комиссии с последующим сбором подписей в поддержку самовыдвижения кандидатов.

Согласно действующему законодательству сбор подписей не осуществляют политические партии, федеральные списки кандидатов которых допущены к распределению депутатских мандатов в Государственной Думе Федерального Собрания Российской Федерации и федеральным спискам кандидатов которых переданы депутатские мандаты, а также региональные отделения и иные структурные подразделения этих политических партий. Федеральный закон от 3 июня 2009 г. № 108-Ф3 «О внесении изменений в отдельные законодательные

${ }^{1}$ Такие дополнительные условия определены пунктом 5 статьи 3 Федерального закона от 10 января 2003 г. № 19-Ф3: «Не имеет право быть избранным Президентом Российской Федерации гражданин Российской Федерации, занимающий на день официального опубликования решения о назначении выборов Президента Российской Федерации должность Президента Российской Федерации второй срок подряд». 
акты Российской Федерации в связи с сокращением количества подписей избирателей в поддержку выдвижения федеральных списков кандидатов на выборах депутатов Государственной Думы Федерального Собрания Российской Федерации и уточнением оснований для регистрации кандидатов, списков кандидатов на выборах в органы государственной власти и органы местного самоуправления» предусмотрел, что на региональных и местных выборах сбор подписей не проводят и политические партии, списки кандидатов которых допущены к распределению депутатских мандатов в действующих на день официального опубликования решения о назначении выборов законодательных (представительных) органах государственной власти не менее чем в одной трети субъектов Российской Федерации, а также региональные отделения и иные структурные подразделения этих политических партий. Регистрация кандидатов и списков кандидатов, выдвинутых такими политическими партиями, их региональными отделениями или иными структурными подразделениями, осуществляется на основании принятых ими решений о выдвижении кандидатов, списков кандидатов ${ }^{1}$.

Учитывая общественную опасность фальсификации подписей избирателей в подписных листах, избирательное законодательство Российской Федерации регламентирует количество подписей, необходимое для регистрации, определяет период сбора подписей, требования к лицам, осуществляющим сбор подписей, место сбора и запреты при сборе подписей. Пункт 6 статьи 37 Федерального закона от 12 июня 2002 г. № 67-Ф3, части 5 и 6 статьи 41, части 11 и 12 статьи 43 Федерального закона от 18 мая 2005 г. № 51-Ф3, пункт 7 статьи 36 Федерального закона от 10 января 2003 г. № 19-Ф3) указывают основания для признания подписей недействительными и недостоверными.

В целях борьбы с административным ресурсом в процессе организации и проведения выборов избирательное законодательство закрепляет гарантии деятельности зарегистрированных кандидатов, а также устанавливает равные

1 Подобные преимущественные права политических партий и кандидатов в депутаты от политических партий Ю.А. Веденеев называет электоральными преференциями. См.: Веденеев Ю.А. Развитие избирательной системы Российской Федерации: проблемы правовой институционализации // Журнал российского права. 2006. № 6. C. 51 . 
возможности для кандидатов, обладающих властными полномочиями, и для кандидатов, не являющихся должностными лицами ${ }^{1}$.

Статья 40 Федерального закона от 12 июня 2002 г. № 67-Ф3 формулирует ограничения, связанные с должностным или служебным положением.

Закон определяет закрытый перечень вариантов использования преимущуеств должностного или служебного положения.

1. Привлечение лиц, находящихся в подчинении или в иной служебной зависимости, государственных и муниципальных служащих к осуществлению в служебное (рабочее) время деятельности, способствующей выдвижению кандидатов, списков кандидатов и (или) избранию кандидатов;

2. Использование помещений, занимаемых государственными органами или органами местного самоуправления, организациями независимо от формы собственности, за исключением помещений, занимаемых политическими партиями, для осуществления деятельности, способствующей выдвижению кандидатов, списков кандидатов и (или) избранию кандидатов, если иным кандидатам, избирательным объединениям не будет гарантировано предоставление указанных помещений на таких же условиях;

3. Использование телефонной, факсимильной и иных видов связи, оргтехники и информационных услуг, обеспечивающих функционирование государственных органов, органов местного самоуправления, государственных и муниципальных учреждений, организаций независимо от формы собственности, за исключением указанных видов связи, оргтехники и информационных услуг, обеспечивающих функционирование политических партий, для проведения предвыборной агитации, если их использование не оплачено из соответствующего избирательного фонда;

4. Использование на безвозмездной основе или на льготных условиях транспортных средств, находящихся в государственной или муниципальной собственности, собственности организаций, за исключением транспортных средств, находящихся в собственности политических партий, для осуществления

${ }^{1}$ См.: Пустошинская О.С. Административный ресурс в избирательном процессе: вопросы правовой оценки и регулирования / Особенности реализации избирательного законодательства на современном этапе. Материалы Всероссийской научно-практической конференции. Тюмень, 2007. С. 142-145. 
деятельности, способствующей выдвижению кандидатов, списков кандидатов и (или) избранию кандидатов;

5. Сбор подписей избирателей, ведение предвыборной агитации лицами, замещающими государственные или выборные муниципальные должности, либо находящимися на государственной или муниципальной службе, либо являющимися главами местных администраций, либо являющимися членами органов управления организаций независимо от формы собственности (в организациях, высшим органом управления которых является собрание, - членами органов, осуществляющих руководство деятельностью этих организаций), за исключением политических партий, в ходе служебных (оплачиваемых за счет средств соответствующего бюджета, средств соответствующей организации) командировок;

6. Доступ (обеспечение доступа) к государственным и муниципальным СМИ в целях сбора подписей избирателей, ведения предвыборной агитации, если иным кандидатам, избирательным объединениям для этих целей не будет гарантирован такой же доступ;

7. Агитационное выступление в период избирательной кампании при проведении публичного мероприятия, организуемого государственными и (или) муниципальными органами, организациями независимо от формы собственности, за исключением политических партий;

8. Обнародование в период избирательной кампании в СМИ, агитационных печатных материалах отчетов о проделанной работе, распространение от имени гражданина, являющегося кандидатом, поздравлений и иных материалов, не оплаченных из средств соответствующего избирательного фонда.

Названные легальные исключения на использование транспортных средств и агитационные выступления при проведении публичных мероприятий, организуемых государственными и (или) муниципальными органами, предусмотренные для политических партий, фактически предоставляют партиям преимущества в ходе избирательной кампании и нарушают равенство прав участников выборов.

Согласно пункту 3 статьи 38 Федерального закона от 12 июня 2002 г. № 67Ф3, пункту 3 статьи 38 Федерального закона от 10 января 2003 г. № 19-Ф3 и части 
7 статьи 43 Федерального закона от 18 мая 2005 г. № 51-Ф3 избирательная комиссия может проверить соблюдение порядка сбора подписей, оформления подписных листов, достоверность сведений об избирателях и подписи избирателей.

Регистрация кандидатов (списка кандидатов) осуществляется соответствующей избирательной комиссией при наличии документов, представляемых в соответствующие избирательные комиссии для уведомления о выдвижении кандидата (списка кандидатов), а также при наличии необходимого количества подписей избирателей, собранных в поддержку выдвижения кандидата (списка кандидатов), либо при наличии решения политической партии, допущенной на основании официально опубликованных результатов ближайших предыдущих выборов депутатов Государственной Думы Федерального Собрания Российской Федерации к распределению депутатских мандатов, о выдвижении кандидатов (списка кандидатов).

Наличие среди подписей избирателей более $10 \%$ подписей, собранных в местах, где сбор подписей запрещен; недостаточное количество достоверных подписей, представленных для регистрации федерального списка кандидатов на выборах депутатов Государственной Думы Федерального Собрания Российской Федерации, либо выявление 5 и более \% недействительных подписей избирателей от общего количества отобранных для проверки подписей являются основаниями для отказа в регистрации федерального списка кандидатов.

Пункт 6 статьи 3 Федерального закона от 12 июня 2002 г. № 67-Ф3, пункт 1 статьи 11 Федерального закона от 10 января 2003 г. № 19-Ф3, часть 1 статьи 12 Федерального закона от 18 мая 2005 г. № 51-Ф3 содержат правовое предписание, в соответствии с которым иностранные граждане, лица без гражданства, иностранные организации, международные организации и международные общественные движения не вправе осуществлять деятельность, способствующую либо препятствующую подготовке и проведению выборов, выдвижению, регистрации и избранию кандидатов (федерального списка кандидатов).

Статья 30.1 Федерального закона от 12 января 1996 г. (в ред. от 23 июля 2008 г.) № 7-Ф3 «О некоммерческих организациях» устанавливает ограничения на 
участие отдельных категорий лиц (в том числе депутатов и выборных должностных лиц) в деятельности иностранных некоммерческих неправительственных организаций ${ }^{1}$. В состав органов управления, попечительских или наблюдательных советов, иных органов иностранных некоммерческих неправительственных организаций и действующих на территории Российской Федерации их структурных подразделений не могут входить лица, замещающие государственные или муниципальные должности, а также должности государственной или муниципальной службы, если иное не предусмотрено международным договором Российской Федерации или законодательством Российской Федерации. Указанные лица не вправе заниматься оплачиваемой деятельностью, финансируемой исключительно за счет средств иностранных государств, международных и иностранных организаций, иностранных граждан и лиц без гражданства, если иное не предусмотрено международным договором Российской Федерации или законодательством Российской Федерации.

В соответствии со статьей 19.1 Закона Российской Федерации «О средствах массовой информации» иностранное юридическое лицо, а равно российское юридическое лицо с иностранным участием, доля (вклад) иностранного участия в уставном (складочном) капитале которого составляет 50 процентов и более, гражданин Российской Федерации, имеющий двойное гражданство, не вправе выступать учредителями теле-, видеопрограмм. Иностранный гражданин, лицо без гражданства и гражданин Российской Федерации, имеющий двойное гражданство, иностранное юридическое лицо, а равно российское юридическое лицо с иностранным участием, доля (вклад) иностранного участия в уставном (складочном) капитале которого составляет 50 процентов и более, не вправе учреждать организации (юридические лица), осуществляющие телевещание, зона уверенного приема передач которых охватывает половину и более половины субъектов Российской Федерации либо территорию, на которой проживает половина и более половины численности населения Российской Федерации.

\footnotetext{
${ }^{1}$ См. Рос. газ. 1996. 24 января.
} 
Перечисленные выше положения федеральных законов дают возможность компетентным государственным органам и учреждениям оказывать противодействие попыткам ряда иностранных государств (иностранных и международных организаций, международных общественных движений) оказывать информационно-пропагандистское, финансовое и политическое воздействие на избирательный процесс в ущерб конституционному строю России, а также осуществлять подкуп депутатов и выборных должностных лиц.

Отдельного внимания с позиций защиты конституционного строя заслуживает стадия информирования избирателей и предвыборной агитации.

В связи с необходимостью адекватного противодействия «грязной» предвыборной агитации, проводимой под предлогом информирования граждан, законодатель разделяет понятия «информирование избирателей» и «предвыборная агитация» ${ }^{1}$. Отграничение информирования избирателей от предвыборной агитации направлено на обеспечение формирования свободного волеизъявления граждан и гласности выборов и отвечает требованиям статей 3 (часть 3), 29 (части 1, 3, 4 и 5), 32 (части 1, 2 и 3) Конституции Российской Федерации, поскольку только когда реально гарантированы право на объективную информацию и свобода выражения мнений, выборы могут считаться свободными ${ }^{2}$. Применительно к СМИ свободу выражения мнений нельзя отождествлять со свободой предвыборной агитации, к которой не предъявляются требования объективности.

Заслуживает поддержки позиция А.М. Осавелюка, который полагает, что ограничения при проведении предвыборной агитации, установленные частью 5.2 статьи 62 Федерального закона «О выборах депутатов Государственной думы Федерального Собрания Российской Федерации», противоречат статье 55 этого

1 Понятия «информирование избирателей» и «предвыборная агитация» различаются по субъектам и содержанию. Информирование избирателей осуществляют органы государственной власти, органы местного самоуправления, избирательные комиссии, организации, осуществляющие выпуск средств массовой информации, юридические и физические лица. Политические партии, кандидаты, доверенные лица субъектами информирования не являются. При этом, в отличие от агитационных материалов, информационные материалы должны быть объективными и достоверными.

${ }^{2}$ См. Постановление Конституционного Суда Российской Федерации от 30 октября 2003 г. № 15-П по делу о проверке конституционности отдельных положений Федерального закона «Об основных гарантиях избирательных прав и права на участие в референдуме граждан Российской Федерации» в связи с запросом группы депутатов Государственной Думы и жалобами граждан С.А. Бунтмана, К.А. Катаняна и К.С. Рожкова // С3 РФ. 2003. Ст. 4358. 
же закона, раскрывающей понятие «предвыборная агитация» ${ }^{1}$. Политическая партия, выдвинувшая федеральный список кандидатов, не вправе использовать эфирное время на каналах организаций, осуществляющих телевещание, предоставленное ей для размещения агитационных материалов, в целях:

1) распространения призывов голосовать против федерального списка кандидатов (федеральных списков кандидатов);

2) описания возможных негативных последствий в случае, если тот или иной федеральный список кандидатов будет допущен к распределению депутатских мандатов (тому или иному федеральному списку кандидатов будут переданы депутатские мандаты), тот или иной кандидат (те или иные кандидаты), включенный (включенные) в федеральный список кандидатов, будет избран (будут избраны);

3) распространения информации, в которой явно преобладают сведения о какой-либо политической партии, выдвинувшей федеральный список кандидатов, каком-либо кандидате (каких-либо кандидатах), включенном (включенных) в федеральный список кандидатов, в сочетании с негативными комментариями;

4) распространения информации, способствующей созданию отрицательного отношения избирателей к политической партии, выдвинувшей федеральный список кандидатов, кандидату (кандидатам), включенному (включенным) в федеральный список кандидатов.

Буквальное толкование комментируемой статьи позволяет сделать вывод о законодательном запрете критики политических соперников на выборах. Между тем, политическая конкуренция в демократическом государстве предполагает полемику, немыслимую без критики оппонента. Ограничение такой критики под предлогом, что она может создать отрицательное отношение к конкуренту, не согласуется с конституционными положениями о свободе мысли и слова.

Как верно отмечает А.М. Осавелюк, отсутствие в законе «юридической обязанности партии, выдвинувшей свой список кандидатов в депутаты, включать в предвыборную агитацию только объективную информацию о своей

\footnotetext{
${ }^{1}$ См.: Осавелюк А.М. Регулирование правового статуса человека современным конституционным правом / Актуальные проблемы современного российского государствоведения. 2009. Вып. 2. / Под ред. С.Н. Бабурина М.: Изд-во РГТЭУ, 2009. С. 188.
} 
предвыборной программе, запрет другим политическим партиям критически ее оценивать способствует тому, что побеждать могут партии, которые распространяют о себе больше хвалебных материалов» ${ }^{1}$.

Федеральные законы и законы субъектов Российской Федерации о выборах, как правило, содержат разделы (главы), регламентирующие порядок и условия ведения предвыборной агитации.

Деятельность кандидатов, избирательных объединений, СМИ в ходе предвыборной агитации должна осуществляться в установленных законодательством пределах. Во-первых, закон закрепляет сроки предвыборной агитации. Во-вторых, закон определяет субъекты агитационной деятельности. Втретьих, закон устанавливает равные условия доступа кандидатов, избирательных объединений к средствам массовой информации ${ }^{2}$.

В соответствии с пунктом 2 статьи 56 Федерального закона от 12 июня 2002 г. № 67-Ф3 при проведении предвыборной агитации запрещается осуществлять подкуп избирателей (участников референдума). При этом законодательно никак не ограничено получение избирателями (участниками референдума) материальных и нематериальных благ в зависимости от итогов голосования, результатов выборов.

Эффективность законодательного противодействия коррупции в избирательном процессе можно было бы повысить путем введения в Кодекс Российской Федерации об административных правонарушениях статьи 5.16.1 «Получение избирателем (участником референдума) выгоды материального и (или) нематериального характера за осуществление волеизъявления» следующего содержания:

«Заполнение избирателями (участниками референдума) подписных листов в поддержку кандидата (списков кандидатов), в поддержку инициативы проведения референдума, голосование за кандидата (список кандидатов), голосование на

\footnotetext{
${ }^{1}$ См.: Осавелюк А.М. Указ. соч. С. 187-188.

2 В отношении споров о нарушении равенства участников избирательного процесса при осуществлении предвыборной агитации и освещении СМИ их деятельности см. Решение Верховного Суда Российской Федерации от 3 июля 2008 г. по делу № ГКПИ08-1472; Решение Верховного Суда Российской Федерации от 16 июля 2008 г. по делу № ГКПИ08-1403.
} 
референдуме либо отказ от голосования, совершенные с целью извлечения выгод материального и (или) нематериального характера, влечет наложение административного штрафа в размере от трех тысяч до пяти тысяч рублей».

Предвыборные программы кандидатов, политических партий, иные агитационные материалы (в том числе размещаемые в информационнотелекоммуникационных сетях общего пользования, включая «Интернет»), выступления кандидатов и их доверенных лиц, представителей политических партий, граждан на публичных мероприятиях, в средствах массовой информации не должны содержать призывы к совершению деяний, определяемых в статье 1 Федерального закона от 25 июля 2002 года № 114-Ф3 «О противодействии экстремистской деятельности» как экстремистская деятельность, либо иным способом побуждать к таким деяниям, а также обосновывать или оправдывать экстремизм. В соответствии с Федеральным законом «О противодействии экстремистской деятельности» экстремистской деятельностью признается:

а) деятельность общественных и религиозных объединений либо иных организаций, либо редакций СМИ, либо физических лиц по планированию, организации, подготовке и совершению действий, направленных на:

- насильственное изменение основ конституционного строя и нарушение целостности Российской Федерации;

- подрыв безопасности Российской Федерации;

- захват или присвоение властных полномочий;

- создание незаконных вооруженных формирований;

- осуществление террористической деятельности либо публичное оправдание терроризма;

- возбуждение расовой, национальной или религиозной розни, а также социальной розни, связанной с насилием или призывами к насилию ${ }^{1}$;

- унижение национального достоинства;

- осуществление массовых беспорядков, хулиганских действий и актов вандализма по мотивам идеологической, политической, расовой, национальной

\footnotetext{
${ }^{1}$ Об агитации, возбуждающей социальную ненависть и вражду, не связанной с насилием см. Определение Судебной коллегии по гражданским делам Верховного Суда Российской Федерации от 10 марта 2006 г. № 71-ГО6-12.
} 
или религиозной ненависти либо вражды, а равно по мотивам ненависти либо вражды в отношении какой-либо социальной группы;

- пропаганду исключительности, превосходства либо неполноценности граждан по признаку их отношения к религии, социальной, расовой, национальной, религиозной или языковой принадлежности;

- воспрепятствование законной деятельности органов государственной власти, избирательных комиссий, а также законной деятельности должностных лиц указанных органов, комиссий, соединенное с насилием или угрозой его применения;

- публичную клевету в отношении лица, замещающего государственную должность Российской Федерации или государственную должность субъекта Российской Федерации, при исполнении им своих должностных обязанностей или в связи с их исполнением, соединенную с обвинением указанного лица в совершении деяний, указанных в статье 1 упомянутого закона, при условии, что факт клеветы установлен в судебном порядке;

- применение насилия в отношении представителя государственной власти либо на угрозу применения насилия в отношении представителя государственной власти или его близких в связи с исполнением им своих должностных обязанностей;

- посягательство на жизнь государственного или общественного деятеля, совершенное в целях прекращения его государственной или иной политической деятельности либо из мести за такую деятельность;

- нарушение прав и свобод человека и гражданина, причинение вреда здоровью и имуществу граждан в связи с их убеждениями, расовой или национальной принадлежностью, вероисповеданием, социальной принадлежностью или социальным происхождением;

- создание и (или) распространение печатных, аудио-, аудиовизуальных и иных материалов (произведений), предназначенных для публичного использования и содержащих хотя бы один из признаков, предусмотренных указанной статьей; 
б) пропаганда и публичное демонстрирование нацистской атрибутики или символики либо атрибутики или символики, сходных с нацистской атрибутикой или символикой до степени смешения;

в) публичные призывы к осуществлению указанной деятельности, а также публичные призывы и выступления, побуждающие к осуществлению указанной деятельности, обосновывающие либо оправдывающие совершение деяний, указанных в статье 1 указанного Федерального закона;

г) финансирование указанной деятельности либо иное содействие в планировании, организации, подготовке и совершении указанных действий, в том числе путем предоставления для осуществления указанной деятельности финансовых средств, недвижимости, учебной, полиграфической и материальнотехнической базы, телефонной, факсимильной и иных видов связи, информационных услуг, иных материально-технических средств.

Анализ содержания Федерального закона «О противодействии экстремистской деятельности» позволяет выявить ряд его недостатков.

1. В законе отсутствует научно-разработанное понятие экстремистской деятельности. Существующее определение экстремизма представляет собой простое перечисление составов преступлений.

2. Законодателем нечетко разграничена экстремистская и террористическая деятельность. Согласно пункту 1 статьи 1 Федерального закона «О противодействии экстремистской деятельности» публичное оправдание терроризма и иная террористическая деятельность являются составной частью экстремизма. Однако в Федеральных законах «О противодействии терроризму» и «О противодействии экстремистской деятельности» имеются составы преступлений, которые одновременно отнесены и к террористическим, и к экстремистским. Примером может служить состав, предусмотренный статьей 205.2 УК РФ «публичные призывы к осуществлению террористической деятельности или публичное оправдание терроризма». С другой стороны, если исходить из того, что терроризм - это компонент экстремизма, возникает вопрос, почему санкции за совершение преступлений экстремистской направленности существенно мягче. 
3. Включение публичной клеветы в отношении лица, замещающего государственную должность Российской Федерации или государственную должность субъекта Российской Федерации, связанной с обвинением указанного лица в совершении экстремистских деяний, в состав экстремизма носит неоднозначный характер и потенциально позволяет использовать правовые положения Федерального закона «О противодействии экстремистской деятельности» в интересах лиц, замещающих государственные должности. Например, критика оппонентами высшего должностного лица субъекта Российской Федерации за проведение несбалансированной национально-кадровой политики в регионе формально-юридически может рассматриваться как экстремизм.

Запреты на подготовку и осуществление экстремистской деятельности в условиях выборов дополняются ограничениями, предусмотренными статьей 9 Федерального закона «О политических партиях». В соответствии с указанной статьей запрещается создание и деятельность политических партий, цели или действия которых направлены на осуществление экстремистской деятельности, а также создание политических партий по признакам профессиональной, расовой, национальной или религиозной принадлежности.

Конституционно-правовая регламентация предвыборной агитации в интересах защиты конституционного строя направлена на предотвращение фактов злоупотребления свободой массовой информации, предупреждение и пресечение экстремистской деятельности кандидатов, политических партий и общественных объединений, недопустимость распространения избирательных технологий манипулятивного воздействия на общественное сознание и дискредитации политических конкурентов.

Действующим законодательством предусмотрена возможность привлечения к ответственности организации телерадиовещания, редакции периодического печатного издания, их должностных лиц в случае нарушения порядка проведения предвыборной агитации и распространения экстремистских материалов (пункт 8 статьи 56 Федерального закона от 12 июня 2002 г. № 67-Ф3, статьи 8 и 11 Федерального закона «О противодействии экстремистской деятельности»). Федеральный закон от 4 июля 2003 года № 94-Ф3 «О внесении изменений и 
дополнений в некоторые законодательные акты Российской Федерации в связи с принятием Федерального закона «Об основных гарантиях избирательных прав и права на участие в референдуме граждан Российской Федерации» дополнил Закон Российской Федерации от 27 декабря 1991 г. № 2141-I «О средствах массовой информации» статьей $16^{1}$ «Приостановление выпуска средства массовой информации за нарушение законодательства Российской Федерации о выборах и референдумах» ${ }^{1}$.

Предусмотренная статьей $16^{1}$ процедура приостановления выпуска СМИ за нарушения законодательства о выборах чрезмерно сложна для практической реализации. Необходимость обращения в федеральный орган исполнительной власти, осуществляющий регистрацию СМИ, пятидневный срок, установленный для проверки фактов нарушения законодательства о выборах, возможность отказа уполномоченного федерального органа исполнительной власти от обращения в суд с заявлением о приостановлении выпуска СМИ позволяют СМИ-нарушителю длительное время безнаказанно продолжать противоправную деятельность, нарушающую законодательство о выборах. В связи с этим представляется целесообразным скорректировать содержание статьи $16^{1}$ Закона Российской Федерации от 27 декабря 1991 г. № 2141-I «О средствах массовой информации»².

В статье 54 Федерального закона от 12 июня 2002 г. № 67-Ф3 закреплены условия выпуска и распространения агитационных материалов (плакатов, листовок, календарей, аудио- и видеопродукции). Все агитационные материалы должны изготавливаться на территории Российской Федерации и содержать сведения об изготовителе, заказчике, информацию о тираже и дате выпуска, указание об оплате их изготовления из средств соответствующего избирательного фонда. Экземпляры печатных агитационных материалов или их копии, экземпляры аудиовизуальных материалов, фотографии и другие материалы до начала их распространения должны предоставляться в соответствующую избирательную комиссию вместе со сведениями о месте нахождения (адресе места жительства) организации (лица), изготовившей и заказавшей (изготовившего и заказавшего) эти материалы. Запрещается изготовление

\footnotetext{
${ }^{1}$ См.: Рос. газ. 2003. 8 июля.

${ }^{2}$ См. Приложение.
} 
агитационных материалов без предварительной оплаты за счет средств соответствующего избирательного фонда.

В соответствии с пунктом 9 статьи 56 Федерального закона от 12 июня 2002 г. № 67-Ф3 правоохранительные органы обязаны принимать меры по предотвращению изготовления подложных и незаконных предвыборных печатных, аудиовизуальных, иных агитационных материалов, их изъятию, а также устанавливать изготовителей указанных материалов и источник их оплаты, а также незамедлительно информировать соответствующую избирательную комиссию о выявленных фактах и принятых мерах.

На основании части 2 статьи 28 Закона Российской Федерации «О средствах массовой информации» изъятие, а равно уничтожение тиража или его части допускается не иначе как по вступившему в силу решению суда ${ }^{1}$. Судебный порядок изъятия, уничтожения тиража (его части) служит гарантией обеспечения законности агитационной деятельности, а также защиты прав СМИ в условиях гласности и свободы выборов.

В условиях растущего распространения информационных технологий в процессе организации и проведения выборов необходимо отметить недостаточную проработанность правовой основы противодействия использования электронных СМИ (прежде всего, телекоммуникационных сетей) для совершения избирательных правонарушений и нанесения ущерба конституционному строю России.

В федеральном законодательстве о выборах следует урегулировать порядок проведения предвыборной агитации посредством сетей связи общего пользования. В частности, предлагается установить ответственность за достоверность размещаемых сведений, запретить анонимное распространение информации в сети и распространение информации агитационного характера, не запрошенной ее получателем. Средства на ведение предвыборной агитации через

${ }^{1}$ По данной проблеме см. также Постановление ЦИК России от 13 октября 2005 г. № 156/1044-4 «О жалобах В.В. Жириновского и П.Н. Гусева на действия Избирательной комиссии Белгородской области», Постановление ЦИК России от 29 сентября 2005 г. № 75/460 «О заявлении кандидата в депутаты Белгородской областной Думы четвертого созыва, выдвинутого в составе общеобластного списка кандидатов в депутаты избирательным объединением «Белгородское региональное отделение Всероссийской политической партии «Единая Россия» Селиверстова Ю.И» и жалобе В.В. Жириновского на Постановление Избирательной комиссии Белгородской области от 6 октября 2005 г. № 77/470 «О заявлении кандидата в депутаты Белгородской областной Думы четвертого созыва, выдвинутого в составе общеобластного списка кандидатов в депутаты избирательным объединением «Белгородское региональное отделение Всероссийской политической партии «Единая Россия» Беспаленко П.Н. // Вестник ЦИК России. 2005. № 11 (190). 
Интернет должны расходоваться из избирательного фонда. Представляется целесообразным зарегистрированные в российском сегменте сайты приравнять к СМИ и с учетом этого к ним применять нормы об ответственности ${ }^{1}$.

Думается, что изложенные меры позволят предотвратить распространение компрометирующих отдельных кандидатов и избирательные объединения материалов и политического «заказа» конкурентов в Интернете в период предвыборной агитации.

Немаловажную роль в защите конституционного строя России в избирательном процессе играет финансирование избирательных кампаний.

Кандидаты и избирательные объединения, выдвинувшие списки кандидатов, обязаны создавать избирательные фонды для финансирования своей избирательной кампании ${ }^{2}$. Запрещается пожертвование в избирательные фонды кандидатов, зарегистрированных кандидатов, избирательных объединений: иностранным государствам и иностранным организациям, иностранным гражданам, лицам без гражданства; международным организациям и международным общественным движениям; российским гражданам, не достигшим возраста 18 лет на день голосования; российским юридическим лицам с иностранным участием, если доля (вклад) иностранного участия в их уставном (складочном) капитале превышает 30\% на день официального опубликования решения о назначении выборов; органам государственной власти, иным государственным органам, органам местного самоуправления; государственным и муниципальным учреждениям, государственным и муниципальным унитарным предприятиям; юридическим лицам, в уставном (складочном) капитале которых доля (вклад) Российской Федерации, субъектов Российской Федерации и (или) муниципальных образований превышает $30 \%$ на день официального опубликования решения о назначении выборов; организациям, учрежденным указанными юридическими лицами; организациям, учрежденным государственными органами и (или) органами местного самоуправления (за исключением акционерных обществ, учрежденных в порядке приватизации);

\footnotetext{
${ }^{1}$ См.: Климова Ю.Н. Распространение информации через Интернет в период избирательной кампании: коммуникативные, криминологические и правовые аспекты. Нижнекамск, 2002. С. 34-35.

2 При проведении выборов в органы местного самоуправления создание кандидатом избирательного фонда необязательно при условии, что число избирателей в избирательном округе не превышает пять тысяч и финансирование кандидатом своей избирательной кампании не производится.
} 
благотворительным и религиозным организациям, а также учрежденным ими организациям; воинским частям, военным учреждениям и организациям, правоохранительным органам; анонимным жертвователям; юридическим лицам, зарегистрированным менее чем за один год до дня голосования на выборах; некоммерческим организациям, получавшим в течение года, предшествующего дню внесения пожертвования в избирательный фонд денежные средства либо иное имущество от перечисленных выше субъектов.

Ограничения в отношении некоммерческих организаций не применяются, если полученные денежные средства либо иное имущество возвращены перечислившим (передавшим) их юридическим или физическим лицам до дня внесения пожертвования в избирательный фонд. Учитывая долгосрочный характер оказания рядом иностранных государств информационнопропагандистского, финансового, политического и силового воздействия на избирательный процесс в целях изменения и подрыва конституционного строя России, срок, предусмотренный законодателем (предшествующий дню внесения пожертвования в избирательный фонд), предлагается увеличить до двух лет ${ }^{1}$. Таким образом, некоммерческие организации, получавшие финансовую и иную материальную поддержку от иностранных государств, иностранных организаций, иностранных граждан и лиц без гражданства, международных организаций и международных общественных движений, а также от иных, указанных в законе органов и организаций в течение двух лет, предшествующих дню внесения пожертвования в избирательный фонд, не смогут вносить указанные пожертвования для финансирования избирательной кампании, не возвратив полученные этими некоммерческими организациями денежные средства либо иное имущество. Предложенная мера позволила бы усилить от иностранного вмешательства и административного ресурса должностных лиц органов государственной власти и органов местного самоуправления правовую защиту конституционного строя России.

Законодательное перечисление перечня субъектов, которым запрещено вносить добровольные пожертвования в избирательные фонды, связано с противодействием попыткам иностранного финансирования выборов в ущерб

\footnotetext{
${ }^{1}$ См. Приложение.
} 
конституционному строю России, а также недопущением нецелевого использования бюджетных средств в избирательном процессе.

Возрастание роли политических партий в избирательном процессе требует должного отражения прозрачности их финансирования.

В соответствии со статьей 68 Федерального закона от 18 мая 2005 г. № 51Ф3 политическая партия, выдвинувшая федеральный список кандидатов, ее региональное отделение, создавшие избирательные фонды, обязаны вести учет поступления средств в избирательные фонды и расходования этих средств. Редакции общероссийских государственных периодических печатных изданий, редакции региональных государственных периодических печатных изданий обязаны публиковать переданные им соответственно Центральной избирательной комиссией Российской Федерации, избирательными комиссиями субъектов Российской Федерации сведения о поступлении средств на специальные избирательные счета и расходовании этих средств, а также сведения из сводных финансовых отчетов политических партий, зарегистрировавших федеральные списки кандидатов, за четыре отчетных года, предшествующие году проведения выборов депутатов Государственной Думы, а если политическая партия была зарегистрирована менее чем за четыре года до года проведения указанных выборов, - за период, который начинается с года регистрации политической партии и заканчивается годом, предшествующим году проведения выборов.

Пункт 8 статьи 62 Федерального закона от 10 января 2003 г. № 19-Ф3 устанавливает обязанность государственных периодических печатных изданий публиковать сведения: о финансовой операции по расходованию средств из избирательного фонда в случае, если ее размер превышает 200 тысяч рублей; о юридических лицах, внесших в избирательный фонд добровольные пожертвования на сумму, превышающую 400 тысяч рублей; о количестве граждан, внесших в избирательный фонд добровольные пожертвования на сумму, превышающую 40 тысяч рублей; о средствах, возвращенных жертвователям, в том числе об основаниях возврата; об общей сумме средств, поступивших в избирательный фонд, и об общей сумме средств, израсходованных из него. 
В статьях 58 Федерального закона от 10 января 2003 г. № 19-ФЗ и 64 Федерального закона от 18 мая 2005 г. № 51-Ф3 определены размеры предельной суммы всех расходов кандидата на должность Президента Российской Федерации из средств его избирательного фонда, расходов из средств избирательного фонда политической партии, а также регионального отделения политической партии.

Указанные правовые меры (учет средств и финансовые отчеты, опубликование сведений о поступлении средств на специальные избирательные счета и расходовании этих средств, установление высокого предельного размера расходов из средств избирательного фонда) позволили усилить контроль политических партий за движением денежных средств и уменьшить возможности криминального влияния на финансирование выборов ${ }^{1}$. Думается, что весьма своевременна постановка вопроса о контроле не только за финансовохозяйственной деятельностью политических партий, но и за их политической рекламой, особенно в предвыборный период. В настоящее время юридические пределы действия Федерального закона от 13 марта 2006 г. № 38-Ф3 «О рекламе», в соответствие с пунктом 1 части 2 статьи 2 данного закона не распространяются на политическую рекламу².

Завершающая стадия избирательной кампании связана с подсчетом голосов и установлением результатов выборов. Конституционно-правовая регламентация данной стадии избирательного процесса осуществляется в главе IX Федерального закона от 12 июня 2002 г. № 67-Ф3.

Процедура голосования является формализованной, что требует от участников выборов, включая членов избирательных комиссий, неуклонного соблюдения всех предусмотренных нормативными правовыми актами условий (статьи 64-66 Федерального закона от 12 июня 2002 г. № 67-Ф3).

В соответствии с пунктом 5 статьи 64 Федерального закона от 12 июня 2002 г. № 67-Ф3 бюллетени выдаются избирателям, включенным в список, по предъявлении паспорта или документа, заменяющего паспорт гражданина, а если

\footnotetext{
1 Как свидетельствует практика, скудное государственное финансирование выборов приводит к восполнению недостающих средств из других источников и способствует росту коррупции в избирательном процессе.

2 В условиях выборов порядок осуществления политической рекламы определяется избирательным законодательством. Вне периода избирательной кампании отношения, связанные с политической рекламой, нормативно не регулируются. Представляется, что данный пробел требует скорейшего восполнения.
} 
избиратель голосует по открепительному удостоверению, - по предъявлении также открепительного удостоверения. Приведенное правовое положение исключает возможность голосования за других граждан.

Для обеспечения правильного подсчета голосов и достоверного установления результатов волеизъявления избирателей важнейшее значение имеет предусмотренное законом погашение неиспользованных избирательных бюллетеней.

В избирательном законодательстве Российской Федерации и нормативных правовых актах ЦИК России поэтапно закреплены порядок подсчета голосов избирателей, заполнения протокола участковой избирательной комиссии об итогах голосования, выдачи копий и работы с протоколом после его подписания большинством членов комиссии с правом решающего голоса. Действующее законодательство запрещает вносить какие-либо изменения в списки избирателей после окончания голосования и начала подсчета голосов. Подсчет голосов начинается сразу после окончания времени голосования и проводится без перерыва до установления итогов голосования, о которых должны быть извещены все члены участковой комиссии, а также наблюдатели. Эти нормы направлены на предотвращение возможности фальсификации итогов голосования.

Универсальные требования к протоколу об итогах голосования позволяют участковым избирательным комиссиям применять единые подходы к их заполнению. Важной гарантией недопущения фальсификации итогов голосования является установленная законом (пункт 22 статьи 68 Федерального закона от 12 июня 2002 г. № 67-Ф3, пункт 21 статьи 73 Федерального закона от 10 января 2003 г. № 19-Ф3, часть 21 статьи 79 Федерального закона от 18 мая 2005 г. № 51 Ф3) проверка контрольных соотношений данных, внесенных в протокол об итогах голосования. На основании подлинных первых экземпляров протокола соответствующие вышестоящие избирательные комиссии устанавливают итоги голосования и определяют результаты выборов. Возможность получения копий протоколов и их заверения является дополнительной гарантией достоверности установления итогов голосования.

При установлении итогов голосования и определении результатов выборов 
для оперативного получения, передачи и обработки информации используется ГАС «Выборы». Механизм контроля за использованием ГАС «Выборы» закреплен в статье 23 Федерального закона «О Государственной автоматизированной системе Российской Федерации «Выборы». Протоколы, сводные таблицы об итогах голосования, иные сводные документы, подготовленные в электронном виде с использованием ГАС «Выборы», приобретают юридическую силу с момента подписания электронными цифровыми подписями соответствующих должностных лиц, после обязательной проверки в установленном порядке с помощью открытых ключей электронных цифровых подписей подлинности всех исходных электронных документов, на основе которых готовился сводный электронный документ.

Конституционно-правовая регламентация избирательного процесса в интересах защиты конституционного строя России предусматривает и другие механизмы недопущения фальсификации итогов голосования и результатов выборов.

Согласно пункту 9 статьи 70 Федерального закона от 12 июня 2002 г. № 67Ф3 избирательная комиссия обязана признать недействительными итоги голосования, во-первых - в случае, если допущенные при проведении голосования или установления итогов голосования нарушения не позволяют с достоверностью установить результаты волеизъявления избирателей, во-вторых - в случае, если они признаны недействительными на части избирательных участков, списки избирателей на которых на момент окончания голосования в совокупности включают не менее чем одну четвертую часть от общего числа избирателей, внесенных в списки на момент окончания голосования в соответствующем избирательном округе; в-третьих, по решению суда.

В случаях признания выборов несостоявшимися или недействительными, а также в случае выбытия кандидатов проводятся повторные выборы.

Статья 78 Федерального закона от 10 января 2003 г. № 19-Ф3 определяет основания для назначения повторных выборов Президента Российской Федерации: «Если выборы Президента Российской Федерации признаны несостоявшимися или недействительными, либо если на день проведения повторного голосования оба зарегистрированных кандидата, по которым 
назначено повторное голосование, сняли свои кандидатуры или выбыли по иным обстоятельствам, либо если при повторном голосовании ни один зарегистрированный кандидат не был избран на должность Президента Российской Федерации, Совет Федерации Федерального Собрания Российской Федерации назначает повторные выборы Президента Российской Федерации».

Важное значение для конституционно-правовой регламентации избирательного процесса в интересах защиты конституционного строя России имеет положение пункта 4 статьи 78 Федерального закона от 10 января 2003 г. № 19-Ф3: «При проведении повторных выборов Президента Российской Федерации кандидатами не могут быть вновь выдвинуты те кандидаты, действия (бездействие) которых послужили (послужило) основанием для признания общих выборов или выборов при повторном голосовании недействительными». Данная норма закона исключает возможность выдвижения и последующего избрания на должность Президента Российской Федерации лиц в связи с правонарушениями при проведении голосования и определении его итогов ${ }^{1}$.

После окончания выборов осуществляется контроль за возвратом бюджетных средств, выделенных в избирательные фонды зарегистрированных кандидатов, избирательных объединений.

Проведенное исследование конституционно-правовой регламентации избирательного процесса в интересах защиты конституционного строя России свидетельствует, что нормативные акты, регулирующие избирательный процесс, охватывают не только сами избирательные процедуры, но и распространяют свое действие на сферу защиты конституционного строя. От того, насколько четко, однозначно и непротиворечиво осуществляется конституционно-правовая регламентация избирательного процесса, зависит защита конституционного строя России.

\section{Выводы:}

\footnotetext{
${ }^{1}$ В целях повышения ответственности партий за несоблюдение правил честной политической конкуренции, предупреждения возможных фальсификаций итогов голосования и результатов выборов депутатов Государственной Думы Федерального Собрания Российской Федерации, предлагается включить аналогичную норму в статью 84 Федерального закона от 18 мая 2005 г. № 51-ФЗ. См. Приложение.
} 
1. В соответствии с конституционным законодательством выборы занимают особое место в системе народовластия России. Выборы можно рассматривать в качестве одной из основ конституционного строя Российской Федерации; высшей формы осуществления непосредственного народовластия; формы реализации конституционного права российских граждан участвовать в управлении делами государства; формы реализации конституционного права избирать и быть избранными в органы государственной власти и органы местного самоуправления; процедуры формирования органов народного представительства. Как основа конституционного строя выборы являются объектом защиты конституционного строя России в сфере организации и функционирования государственной власти. Периодическое проведение выборов выступает гарантом своевременного воспроизводства институтов государственной власти и местного самоуправления и обеспечивает стабильность конституционного строя. Выборы служат индикатором доверия народа к власти и важнейшим способом ее легитимации. Приход к власти представителей тех или иных политических сил с помощью выборов обусловливает определенное состояние защищенности конституционного строя.

Защита конституционного строя России является направлением обеспечения национальной безопасности, включающим в себя защиту основных прав и свобод человека и гражданина, обеспечение народовластия, верховенства и прямого действия Конституции Российской Федерации на всей территории государства, территориальной целостности и суверенитета, поощрение политического и идеологического плюрализма, развитие конституционного контроля за государственными и муниципальными органами, а также привлечение к юридической ответственности за нарушение конституционных норм.

2. Защита конституционного строя в условиях выборов зависит от качества нормативного правового регулирования выборов. Правовое регулирование организации и проведения выборов оказывает целенаправленное управляющее воздействие на значительный спектр общественных отношений, складывающихся в ходе выборов, в том числе и на общественные отношения, возникающие в связи с защитой конституционного строя России в избирательном процессе. 
Содержание нормативного правового регулирования организации и проведения выборов выступает внутренней характеристикой избирательного процесса. Рассмотрение содержания нормативного правового регулирования организации и проведения выборов дало возможность обозначить три уровня в системе нормативных правовых актов, регулирующих избирательный процесс в Российской Федерации: международно-правовой, федеральный и уровень субъектов Российской Федерации.

3. Составной частью защиты конституционного строя России в условиях выборов является конституционно-правовая регламентация стадий избирательного процесса в интересах защиты конституционного строя России. Конституционно-правовая регламентация стадий избирательного процесса в интересах защиты конституционного строя включает в себя создание предусмотренных нормативными правовыми актами условий и правовых гарантий, необходимых государству для защиты конституционного строя в избирательном процессе.

Характерной особенностью конституционно-правовой регламентации избирательного процесса в интересах защиты конституционного строя России является установление ограничений правосубъектности участников выборов (требования к членам избирательных комиссий, наблюдателям, кандидатам, политическим партиям, средствам массовой информации; ограничения, связанные с выдвижением и регистрацией кандидатов; ограничения на участие в деятельности иностранных некоммерческих неправительственных организаций; ограничения на финансирование и предвыборную агитацию и др.). Данные ограничения являются адекватными, пропорциональными, соразмерными и необходимыми для защиты конституционных ценностей. Вместе с тем, ряд правовых ограничений в избирательном процессе не связан с защитой публичных интересов, перечисленных в части 3 статьи 55 Конституции, и представляется чрезмерным. К ним можно отнести: ограничение на включение военнослужащих, проходящих службу по призыву, в списки избирателей при выборах в органы местного самоуправления; лишение избирателей, не являющихся членами политических партий, права самовыдвижения на выборах в Государственную Думу Федерального Собрания Российской Федерации; ограничения на 
использование кандидатами и избирательными объединениями (кроме политических партий) транспортных средств и агитационные выступления при проведении публичных мероприятий, организованных государственными или муниципальными органами. Наличие таких нормативных предписаний в избирательном процессе снижает общую положительную направленность конституционно-правовой регламентации избирательного процесса в интересах защиты конституционного строя. 


\section{ГЛАВа 2. ГЕНЕЗИС И ОБЩАЯ ХАРАКТЕРИСТИКА ПРОБЛЕМЫ ПРАВОВОГО ОБЕСПЕЧЕНИЯ ЗАЩИТЫ КОНСТИТУЦИОННОГО СТРОЯ В ПРОЦЕССЕ ОРГАНИЗАЦИИ И ПРОВЕДЕНИЯ ВЫБОРОВ В РОССИЙСКОЙ ФЕДЕРАЦИИ}

2.1. Общее состояние правового обеспечения защиты конституционного строя В процессе организации и проведения выборов В Российской Федерации

Научное исследование проблемы правовой защиты конституционного строя в избирательном процессе прошло в своем становлении ряд этапов.

В рамках советского этапа исследований закрытыми научноисследовательскими учреждениями и учебными заведениями КГБ СССР и ГРУ ГШ МО СССР активно изучались вопросы противодействия идеологической диверсии. Тематическое развертывание предметной области осуществлялось в рамках изучения внешних угроз конституционному строю и организации контрпропагандистской работы на данном направлении. Открытые разработки носили идеологизированный характер и были направлены на разоблачение фальсификаций марксистско-ленинского учения о партии, а также критику буржуазных демократических теорий ${ }^{1}$. Отдельные работы затрагивали проблемы конституционной законности, конституционного контроля и конституционных гарантий прав и свобод².

Защита конституционного строя рассматривалась с классовых позиций как сохранение с помощью аппарата управления и принуждения экономического, политического и идеологического господства правящей социальной группы

\footnotetext{
${ }^{1}$ См. Актуальные вопросы современной идеологической борьбы. Политиздат, 1980; Правда против лжи и демагогии. Политиздат, 1983; Волкогонов Д.А. Психологическая война. Воениздат, 1983; Apmeмов B.Л. Контрпропаганда как часть идеологической работы / Правда о неправде. Политиздат, 1984; Кейзеров Н.М., Ножин E.A. Контрпропаганда: проблемы методологии и методики. М.: Мысль, 1984.80 с; Кейзеров H.M. Методологические аспекты повышения эффективности борьбы против буржуазной политической и правовой идеологии / Методология и эффективность правовой науки. М., 1972. С. 31-32.

2 См. Ильинский И.П., Щетинин Б.В. Конституционный контроль и охрана конституционной законности в социалистических странах // Советское государство и право. 1969. № 9. С. 40-48; Щетинин Б.В. Советская избирательная система. М.: Знание, 1974. 64 с; Боброва Н.А. О конституционных гарантиях основных прав, свобод и обязанностей граждан СССР // Советское государство и право. 1979. № 3. С. 3-9; Боброва Н.А. Гарантии реализации государственно-правовых норм. Воронеж, 1984. 163 с; Ржевский B.A. О понятии и конституционном закреплении общественно-политического строя СССР // Правоведение. 1969. № 1. С. 45-53; Ржевский B.A. Воплощение суверенитета советского народа в конституционных институтах общественно-политического строя СССР. Автореф. дис. ... д-ра юрид. наук. Ленинград, 1974, 50 с; Теоретические основы советской Конституции / Отв. ред. Топорнин Б.Н. М.: Наука, 1981. С. 176-177.
} 
(класса). Избирательные кампании проводились на безальтернативной однопартийной основе.

В 1988 г. проводимые в СССР и союзных республиках политические реформы затронули советскую избирательную систему. В соответствии с Законом от 1 декабря 1988 г. № 9853-XI внесены поправки в Конституцию СССР, Закон «О выборах народных депутатов СССР», создан постоянно действующий парламент и состоялись первые свободные конкурентные выборы ${ }^{1}$.

После 1990 г. исследование проблем защиты конституционного строя и обеспечения безопасности выходит за рамки специализированных закрытых учреждений. В апреле 1990 г. был создан Фонд национальной и международной безопасности. По инициативе Комитета Верховного Совета СССР по науке, народному образованию, культуре и воспитанию депутатской группой была разработана первая концепция обеспечения безопасности СССР. Постановлением Верховного Совета СССР от 29 августа 1991 г. № 2371-I «О ситуации, возникшей в стране в связи с имевшим место государственным переворотом» было рекомендовано внести «необходимые изменения и дополнения в Конституцию СССР и другие законодательные акты, определяющие правовой механизм защиты конституционного строя» ${ }^{2}$.

В 1992 г. принят Закон Российской Федерации № 2446-1 «О безопасности», впервые установивший открытые правовые основы обеспечения безопасности личности, общества и государства, систему безопасности и ее функции. Законом Российской Федерации от 21 апреля 1992 г. № 2708-1 «Об изменениях и дополнениях Конституции (Основного Закона) РСФСР» Конституционный Суд определен в качестве высшего органа судебной власти по защите конституционного строя ${ }^{3}$. В соответствии с Законом Российской Федерации от 9 октября 1992 г. № 3618-1 «О защите конституционных органов власти в Российской Федерации» была предусмотрена уголовная ответственность за

\footnotetext{
${ }^{1}$ См. Ведомости ВС СССР. 1988. № 49. Ст. 727.

${ }^{2}$ См. Ведомости СНД СССР и ВС СССР. 1991. № 36. Ст. 1038.

${ }^{3}$ См. Рос. газ. 1992. 16 мая.
} 
призывы к насильственному изменению конституционного строя и воспрепятствование деятельности конституционных органов власти ${ }^{1}$

Произошедшие в начале $90-$ х гг. ХX в. распад Советского Союза, ориентация нового руководства России на политику стран «западной демократии», деидеологизация политической жизни, резкое сокращение финансирования фундаментальных и прикладных исследований привели к прекращению научных работ по данной тематике. В условиях социальнополитической нестабильности приоритетными стали внутренние угрозы конституционному строю России. Сепаратистские тенденции, антиконституционные методы ведения политической борьбы, углубляющаяся социальная напряженность, неразвитость институтов гражданского общества, недостаток политической культуры граждан требовали реакции на происходящие деструктивные политические процессы. Ряд ученых-юристов выступил с предложением включить в проект российской Конституции раздел о защите ее конституционного строя ${ }^{2} .23$ июня 1992 г. состоялись парламентские слушания по вопросу «Угроза конституционному строю в стране в связи с активизацией экстремистских сил», 26 июня 1992 г. Конституционный Суд Российской Федерации выступил с заявлением № 3-3 «Конституционный строй государства под угрозой» ${ }^{3}$. В документах отмечалась недопустимость устранения конституционных органов власти, силового подавления политической оппозиции, нарушения законности.

Продолжающееся в 1992-1993 гг. противостояние политических сил (Президента Российской Федерации, Съезда народных депутатов Российской Федерации и Верховного Совета Российской Федерации) привело к неизбежному конституционному кризису ${ }^{4}$. Указом Президента Российской Федерации от 21 сентября 1993 г. № 1400 «О поэтапной конституционной реформе в Российской Федерации» было «прервано осуществление законодательной, распорядительной

\footnotetext{
${ }^{1}$ См. Рос. газ. 1992. 27 октября.

${ }^{2}$ См.: Масленников В.А., Мицкевич А.В., Тихомиров Ю.А., Пяткина С.А. и др. Концептуальные положения новой Конституции Республики // Государство и право. 1992. № 8. С. 29.

${ }^{3}$ См. Рос. газ. 1992. 26 июня; 1992. 27 июня.

4 Об оценке роли Конституционного Суда Российской Федерации в политическом кризисе 1993 г. см. Петренко Д.С. Органы конституционного правосудия как участники политических отношений / Актуальные проблемы современного российского государствоведения. 2009. Вып. 2 / Под ред. С.Н. Бабурина М.: Изд-во РГТЭУ, 2009. С. 256-259.
} 
и контрольной функций Съездом народных депутатов Российской Федерации и Верховным Советом Российской Федерации», введено в действие Положение о федеральных органах власти на переходный период и Положение о выборах в Государственную Думу Федерального Собрания Российской Федерации ${ }^{1}$

Антиконституционные действия Президента Российской Федерации в отношении законно избранных органов государственной власти вызвали вооруженные столкновения. Президентом были прекращены полномочия советов всех уровней и назначено всенародное голосование по Конституции Российской Федерации ${ }^{2}$. После ее принятия 12 декабря 1993 г. было положено начало формированию новой системы организации государственной власти в России и новой избирательной системы.

В 1996 году Президент Российской Федерации направил Федеральному Собранию Послание по национальной безопасности, результатом рассмотрения которого явились проведенные 25 июля 1996 г. парламентские слушания «О Концепции национальной безопасности Российской Федерации». Основополагающие идеи президентского Послания Федеральному Собранию легли в основу Концепции национальной безопасности Российской Федерации, утвержденной указом Президента Российской Федерации от 17 декабря 1997 г. № $1300^{3}$.

Приоритетным направлением внешнеполитического курса России объявлялась деятельность по обеспечению нерушимости границ и территориальной целостности государства, по защите его конституционного строя от возможных посягательств других государств. Защита конституционного строя во внутриполитической сфере раскрывалась в Концепции через обеспечение гражданского мира, национального согласия, территориальной

${ }^{1}$ См. Собрание актов Президента и Правительства РФ. 1993. № 39. Ст. 3597. Данный указ Президента был признан 21 сентября 1993 г. Конституционным Судом Российской Федерации не соответствующим части второй статьи 1 , части второй статьи 2 , статье 3 , части второй статьи 4 , частям первой и третьей статьи 104 , части третьей пункта 11 статьи $121^{5}$, статье $121^{6}$, части второй статьи $121^{8}$, статьям $165^{1}$, 177 Конституции Российской Федерации.

2 Анализ исторических условий разработки и принятия Конституции Российской Федерации дан в работах С.А. Авакьяна, Е.А. Лукьяновой, Н.А. Бобровой и др. ученых. См.: Авакьян С.А. Конституция России: природа, эволюция, современность. М.: Изд-во МГУ, 1997. С. 122-192; Лукьянова Е.А. Из истории беззакония: как в 1993 году принимали Основной Закон Российской Федерации // Независимая газета. 1999. 2 октября; Боброва Н.A. Конституционный строй и конституционализм в России. Монография. М.: Закон и право, 2003. С. 162-176.

${ }^{3}$ См. Указ Президента Российской Федерации от 17 декабря 1997 г. № 1300 «Об утверждении Концепции национальной безопасности Российской Федерации» // С3 РФ. 1997. № 52. Ст. 5909. [Утратил силу]. 
целостности, единства правового пространства, стабильности государственной власти и еe институтов, правопорядка, завершение процесса становления демократического общества, а также нейтрализацию причин и условий, способствующих возникновению социальных и межнациональных конфликтов, национального и регионального сепаратизма. В официальном государственном документе был впервые реализован демократический подход к защите конституционного строя, предполагающий защиту основных прав и свобод человека и гражданина, обеспечение верховенства и прямого действия Конституции на всей территории государства, территориальной целостности и суверенитета, поощрение политического плюрализма, развитие конституционного контроля за выборными и назначаемыми государственными и муниципальными органами, а также охрану демократической государственной власти. В ходе парламентских слушаний 1998 г. были намечены пути реализации принятой Концепции, одним из которых стало предложение «разработать проекты федеральных законов «О защите конституционного строя в Российской Федерации», «Об обеспечении государственной целостности и о соблюдении Конституции Российской Федерации и федеральных законов» .

На втором этапе научных исследований правовой защиты конституционного строя в избирательном процессе $(2000-2005$ гг.) активизировались разработки, связанные с укреплением конституционной законности и единства правового пространства Российской Федерации ${ }^{2}$.

Этот фрагмент государственной деятельности получил официальное закрепление в новой редакции Концепции национальной безопасности Российской Федерации 2000 г., утвержденной Главой государства 3 .

\footnotetext{
${ }^{1}$ См. Постановление Совета Федерации от 2 декабря 1998 г. № 519-СФ «О парламентских слушаниях «О путях реализации Концепции национальной безопасности Российской Федерации» // СЗ РФ. 1998. № 49. Ст. 5995.

${ }^{2}$ См.: Глебов И.Н. Национальная безопасность Российской Федерации: проблемы правового регулирования. СПб., 2000; Гончаров И.В. Федеральное вмешательство в дела субъектов Федерации как средство обеспечения конституционной безопасности России. М., 2002; Зорькин В.Д. Об угрозах конституционного строя в XXI веке и необходимости проведения правовой реформы в России // Журнал российского права. 2004. № 6. С. 3-17; Идрисов $P . \Phi$. Теоретические и правовые проблемы обеспечения национальной безопасности Российской Федерации: Дис. ... докт. юрид. наук. М., 2002; Мамонов В.B. Конституционные основы национальной безопасности Российской Федерации: Дис. ... докт. юрид. наук. Саратов, 2004; Порошкина Ю.О. Проблемы законодательного обеспечения национальной безопасности Российской Федерации М., 2002; Райгородский В.Л. Национальная безопасность России: политико-правовые средства обеспечения. Ростов-н/Д., 2004; Шуберт Т.Э. Национальная безопасность России: конституционно-правовые аспекты. М., 2001.

${ }^{3}$ См. Указ Президента Российской Федерации от 10 января 2000 г. № 24 «О Концепции национальной безопасности Российской Федерации» // Рос. газ. 2000. 18 января.
} 
Концепция национальной безопасности впервые конкретизировала основные направления защиты конституционного строя в России. К ним были отнесены: обеспечение приоритета федерального законодательства и совершенствование на этой основе законодательства субъектов Российской Федерации; разработка организационных и правовых механизмов защиты государственной целостности, обеспечение единства правового пространства и национальных интересов России; выработка и реализация региональной политики, обеспечивающей оптимальный баланс федеральных и региональных интересов; совершенствование механизма, препятствующего созданию политических партий и общественных объединений, преследующих сепаратистские и антиконституционные цели, и пресечение их деятельности.

Особенностью данного этапа научной разработки проблемы стало проведение научных исследований методологического характера, касающихся защиты конституционных основ государственной власти. Специальные исследования в области методологии правового регулирования конституционноправовых основ безопасности России провели В.Г. Вишняков, Л.В. Андриченко, С.А. Боголюбов и др ${ }^{1}$.

Третий этап (2005 - н.в.) изучения проблемы правовой защиты конституционного строя в избирательном процессе наступил после серии «цветных» революций в Украине, Грузии, Кыргызстане. Возникла потребность в научных исследованиях, касающихся противодействия иностранному вмешательству в политический и избирательный процессы, а также исследования вопросов конституционно-правовой легитимации избирательного процесса. В рамках перспективных научных разработок в интересах органов государственной власти появились работы И.Б. Борисова, А.А. Вешнякова, И.А. Евланова, А.В. Иванченко, В.И. Лысенко, В.Е. Чурова, посвященные осуществлению международного наблюдения за выборами и направлениям его

1 См.: Вишняков В.Г., Андриченко Л.В., Боголюбов С.А. и др. Национальная безопасность Российской Федерации: проблемы укрепления государственно-правовых основ // Журнал российского права. 2005. № 2; Вишняков B.Г. О методологических основах правового регулирования проблем безопасности Российской Федерации // Журнал российского права. 2005. № 9. 
совершенствования по линии защиты конституционного строя ${ }^{1}$. Исследование проблем легитимации избирательного процесса в интересах защиты конституционного строя провели И.Б.Борисов, О.В.Дамаскин, В.А.Малиновский и С.А. Пунтус ${ }^{2}$.

Параллельно осуществлялось дальнейшее осмысление концептуальных вопросов обеспечения национальной безопасности. Декларативность Концепции национальной безопасности, отсутствие правовых механизмов ее реализации обусловили появление научных публикаций, в которых обосновывалась необходимость разработки и принятия Федеральных законов «О национальной безопасности Российской Федерации», «О Совете Безопасности Российской Федерации», a также утверждения Стратегии национальной безопасности Российской Федерации как основы для конституционно-правового развития в данной области ${ }^{3}$. Совет Федерации выступил с инициативой создания совместной рабочей группы из представителей Администрации Президента Российской Федерации, палат Федерального Собрания, Правительства Российской Федерации и Совета Безопасности Российской Федерации для разработки проектов соответствующих федеральных законов ${ }^{4}$. Результатом правотворчества и соответствующей научно-методической работы стал перевод теоретических наработок, связанных с правовой защитой конституционного строя, в рамки исследования национальной безопасности.

${ }^{1}$ См.: Борисов И.Б. Электоральный суверенитет или внешнее управление // Профиль. 2008. № 22. С. 22-23; Борисов И.Б. Ведут ли уличные акции к прямому народовластию // Рос. газ. 2009. 20 февраля; Вешняков A.A. Новые избирательные технологии и проблемы наблюдения за выборами // Журнал о выборах. 2005. № 3. С. 54-59; Иванченко A.B. Национальные выборы и принципы международного наблюдения // Журнал о выборах. 2008 . № 5. С. 43-47; Лыссенко В.И., Евланов И.А. Выборы - по демократическим стандартам // Журнал о выборах. 2005. № 3. С. 58-59; Лысенко В.И., Евланов И.А. Новый шаг в развитии международных избирательных стандартов // Журнал о выборах. 2008. № 6. С. 8-16; Чуров B.E. Суверенная демократия и выборы // Рос. газ. 2007. 30 марта.

${ }^{2}$ См.: Борисов И.Б. Проблемы международной легитимации выборов // Право и политика. 2006. № 10. С. 79 86; Дамаскин O.B. Легитимация результатов избирательного процесса в Российской Федерации // Журнал о выборах. 2008. № 3. С. 14-19; Малиновский В.А. Международное наблюдение за выборами: обеспечение объективности или правовая основа для политических манипуляций? // Конституционное и муниципальное право. 2006. № 6. С. 42-47; Пунтус С.А. Институт внешнего (иностранного и международного) наблюдения за выборами как условие легитимности и транспарентности избирательного процесса / Актуальные проблемы борьбы с преступностью в Сибирском регионе. Сб. материалов XII Международной науч.-практ. конф. Ч.2. Красноярск, 2009. C. 60-64.

${ }^{3}$ См.: Варламов В.Ю. Каким быть закону о национальной безопасности? // Государственная власть и местное самоуправление. 2003. № 4. С. 36-39; Шарихин A.E. К вопросу о необходимости разработки и принятия Федерального закона «О национальной безопасности Российской Федерации» // Вестник Московского университета МВД России. 2006. № 6. С. 61-63.

${ }^{4}$ См. Постановление Совета Федерации Федерального Собрания Российской Федерации от 11 марта 2005 г. № 67-СФ «О докладе Совета Федерации Федерального Собрания Российской Федерации 2004 года «О состоянии законодательства в Российской Федерации» // С3 РФ. 2005. № 12. Ст. 975; Постановление Совета Федерации Федерального Собрания Российской Федерации от 8 февраля 2006 г. № 36-СФ «О докладе Совета Федерации Федерального Собрания Российской Федерации 2005 года «О состоянии законодательства в Российской Федерации» // СЗ РФ. 2006. № 7. Ст. 746. 
В 2009 г. указом Президента Российской Федерации от 12 мая 2009 г. № 537 утверждена Стратегия национальной безопасности Российской Федерации до 2020 года ${ }^{1}$.

В числе национальных интересов Российской Федерации на долгосрочную перспективу закреплены: развитие демократии и гражданского общества; повышение конкурентоспособности национальной экономики; обеспечение незыблемости конституционного строя, территориальной целостности и суверенитета Российской Федерации; превращение Российской Федерации в мировую державу, деятельность которой направлена на поддержание стратегической стабильности и взаимовыгодных партнерских отношений в условиях многополярного мира.

Стратегическими целями обеспечения национальной безопасности в сфере государственной и общественной безопасности названы защита основ конституционного строя Российской Федерации, основных прав и свобод человека и гражданина, охрана суверенитета Российской Федерации, ее независимости и территориальной целостности, а также сохранение гражданского мира, политической и социальной стабильности в обществе. Стратегия национальной безопасности Российской Федерации развивает политико-правовую конструкцию демократических правовых государств, в которых интересы защиты конституционного строя являются составной частью национальных интересов.

Систематизируя проведенные за последние 10 лет теоретические исследования в рассматриваемой области, можно выделить несколько ключевых направлений изучения конституционного строя России и его правовой защиты.

Первое направление связано с исследованием основ конституционного строя в качестве предмета конституционно-правового регулирования (В.Д. Ардашкин, М.В. Баглай, Н.А. Боброва, Н.А. Богданова, Н.В. Бутусова, Ю.П. Еременко, В.Т. Кабышев, Д.М. Качмазова, Е.И. Козлова, О.Е. Кутафин, В.В. Новинский, Г.Н. Носкова, О.Г. Румянцев, М.Д. Сомов, Н.А.Ткачева, В.А. Усанов,

\footnotetext{
${ }^{1}$ См. Рос. газ. 2009. 19 мая.
} 
А.С. Янюшкин $)^{1}$. Вопросы защиты конституционного строя рассматривались авторами как второстепенные.

Второе направление охватывает разработку основ конституционного строя в контексте уголовно-правовой и криминологической проблематики (С.Д. Гринько, С.В. Дьяков, А.Г. Климчак, И.А. Колпаков) $)^{2}$ Главное внимание исследователи уделяли уголовно-правовой защите конституционного строя России.

Tретье направление представлено отдельными работами, непосредственно связанными с проблемой правовой защиты конституционного строя в избирательном процессе (И.Н. Гальвина, А.В. Иванченко, Е.М. Марина, Т.А. Прудникова, А.А. Фомин, Д.В. Царев) $)^{3}$.

Проведенный ретроспективный анализ позволяет рассмотреть процесс теоретического исследования правового обеспечения защиты конституционного строя в избирательном процессе. Изучение генезиса проблемы свидетельствует, что проблема защиты конституционного строя в избирательном процессе, несмотря на ее политико-правовую значимость, стала разрабатываться

1 См.: Ардашкин В.Д. Конституционный строй Российской Федерации: основы, структура, проблемы развития // Теория государства и права. Сб. статей. Красноярск, 2004. С. 36-43; Баглай М.В. Конституционное право Российской Федерации. М., 2001. С. 98; Боброва Н.А.. Конституционный строй и конституционализм в России (проблемы методологии, теории, практики). Автореф. дис. ... д-ра юрид. наук. М., 2004. 48 с; Богданова Н.A. Система науки конституционного права М., 2001. С. 161; Бутусова Н.В. Основы конституционного строя Российской Федерации как правовой институт и предмет конституционно-правового регулирования // Вестник Московского университета. 2003. № 6. С. 17-29; Еременко Ю.П. Советская конституция и законность. Саратов, 1982. С. 18; Кабышев В.T. Становление конституционного строя России. Саратов, 1993. С. 4; Качмазова Д.М. Основы конституционного строя субъектов Российской Федерации: общее и особенное. Закон. 2010. № 1. С. 140144; Козлова Е.И., Кутафин О.Е. Конституционное право России. М., 2006. С. 94-100; Новинский В.В. Основы конституционного строя как система конституционных принципов // Российский юридический журнал. 2004. № 1. Екатеринбург, 2004. С. 9-15; Носкова Г.Н. Народовластие - основа конституционного строя Российской Федерации // Конституционное развитие России. Межвуз. сб. науч. статей. Вып. 6. Саратов, 2005. С. 103-110; Румянцев О.Г. Основы конституционного строя: понятие, содержание, отражение в Конституции // Государство и право. 1993. № 10. С. 3-15; Сомов М.Д. Правовые основы конституционного строя, тенденции их развития // Труды филиала МГЮА в г. Вологде. Вып. 4. Вологда, 2005. С. 131-150; Ткачева Н.А. Проблема гарантированности основ конституционного строя. Дис. ... канд. юрид. наук. Ставрополь, 2004. 179 с; Усанов В.А. Многопартийность как необходимое условие парламентаризма и основа конституционного строя // Право и жизнь. 2005. № 85. С. 17-42; Янюшкин А.С. Политические основы конституционного строя Российской Федерации в конституциях и уставах субъектов Российской Федерации. Автореф. дис. ...канд. юрид. наук. М., 2009. 20 с.

${ }^{2}$ См.: Гринько С.Д. Уголовно-правовые и криминологические проблемы противодействия посягательствам на основы конституционного строя и безопасность государства. Автореф. дис. ... доктора. юрид. наук. М., 2008. 55 c; Дьяков С.В. Преступления против основ конституционного строя и безопасности государства: уголовноправовое и криминологическое исследование. Спб, 2009. 267 с; Климчак А.Г. Понятие и признаки преступлений против основ конституционного строя и безопасности государства в России // Развитие законодательства на современном этапе. VIII Международная научная конференция. Москва, 17 апреля 2008 г. М.: РГГУ, 2008. С. 162164; Колпаков И.А. Понятие и виды преступлений против основ конституционного строя и безопасности государства // Актуальные проблемы уголовного права и процесса. Вып. 1. М., 2006. С. 113-117.

${ }^{3}$ См.: Гальвина И.Н. Охрана и защита конституционного строя Российской Федерации. Автореф. дис. ... канд. юрид. наук. Челябинск, 2006. 26 с; Иванченко А.В., Прудникова Т.А. Конституционно-правовые гарантии от монополизации власти // Вестник Московского университета МВД России. 2004. № 2. C. 36-39; Мapuнa E.M., Фомин A.A. Обеспечение Конституционным Судом Российской Федерации правовой безопасности участников избирательного процесса // Актуальные проблемы политики и права. Межвузовский сб. науч. статей. Вып. 6. Пенза, 2003. С. 188-192; Царев Д.В. Защита основ государственной власти в нормах Конституции и УК РФ // Иваново-Вознесенский юридический вестник. 2003. № 11/12. Иваново, 2003. С. 9-12. 
сравнительно недавно. В советский период избирательный процесс был формализован, реальных угроз конституционному строю в условиях выборов не возникало. Исследования носили разрозненный внутриведомственный характер. Этим обстоятельством объяснялась фрагментарность теоретических разработок в рассматриваемой предметной области. В 90-е гг. ХХ в. исследования не проводились в связи со становлением нового конституционного строя, отсутствием долгосрочной стратегии политического развития государства и ошибочными представлениями руководства страны о фиктивности угроз конституционному строю России в избирательном процессе. Последующие работы (с 2000 по 2005 гг.) охватывали, главным образом, узкую проблематику обеспечения единства правового пространства и определения порядка взаимоотношений федеральных и региональных органов власти. Недостаток знаний, обеспечивающих системность и полноту научных исследований проблемы правовой защиты конституционного строя в избирательном процессе, остро проявился в связи с использованием отдельными иностранными государствами технологий захвата политической власти в условиях выборов для осуществления «цветных» революций. С этого момента разработка проблемы правового обеспечения защиты конституционного строя в избирательном процессе вышла на качественно иной уровень. Методология исследований стала носить комплексный характер и включила в себя не только внешний аспект (противодействие иностранному вмешательству в избирательный процесс), но и ориентацию на деструктивные внутриполитические явления политической системы российского общества (монополизацию политической власти, партийную коррупцию, криминализацию государственного аппарата, экстремизм и др.).

В настоящее время исследование правового обеспечения защиты конституционного строя в избирательном процессе становится полинаучным. К изучению различных аспектов защиты конституционного строя привлекаются философы, экономисты, социологи, компаративисты, государствоведы и другие ученые. 
B качестве перспектив дальнейшей научной разработки затронутой проблемы правового обеспечения защиты конституционного строя России в избирательном процессе можно рассматривать:

- анализ и юридическое закрепление угроз конституционному строю, возникающих в избирательном процессе;

- исследование механизма легитимации результатов выборов с позиций правовой защиты конституционного строя;

- изучение отечественной и зарубежных избирательных систем в интересах защиты избирательных прав граждан и укрепления российской государственности;

- выявление и устранение коррупциогенных норм законодательства о выборах в Российской Федерации;

- совершенствование законодательства о политических партиях и средствах массовой информации в интересах защиты конституционного строя России.

Изучение общего состояния правового обеспечения защиты конституционного строя России в избирательном процессе необходимо осуществлять на основе анализа результатов правотворческой деятельности государства в связи с обеспечением защиты конституционного строя России в избирательном процессе.

Правовое обеспечение защиты конституционного строя в избирательном процессе является составной частью защиты конституционного строя России в условиях выборов и представляет собой деятельность государства в лице компетентных государственных органов по созданию, изменению, отмене и реализации правовых норм, способствующих организации и функционированию конституционно-правового механизма защиты конституционного строя России в избирательном процессе. Эти правовые нормы закреплены в системе нормативных правовых актов, являющихся фундаментом проведения государственной политики защиты конституционного строя в ходе выборов.

Правовое обеспечение защиты конституционного строя России в избирательном процессе осуществляется на уровне конституционных положений, федеральных законов, нормативных правовых актов федеральных органов 
государственной власти, законодательных и подзаконных актов субъектов Российской Федерации ${ }^{1}$.

По своей структуре нормативная правовая основа защиты конституционного строя в процессе организации и проведения выборов представлена тремя основными группами нормативных правовых актов:

- нормативными правовыми актами, определяющими общие принципы, функции и систему защиты конституционного строя в процессе организации и проведения выборов в Российской Федерации;

- нормативными правовыми актами, устанавливающими гарантии законности прохождения избирательного процесса, свободной реализации избирательных прав, а также обеспечивающими защиту демократических принципов и норм избирательного права;

- нормативными правовыми актами, регламентирующими правовой статус, задачи и возможные формы участия государственных (в том числе правоохранительных) органов и учреждений в обеспечении защиты конституционного строя Российской Федерации в условиях выборов.

По юридической силе нормативную правовую основу защиты конституционного строя в избирательном процессе составляет совокупность законодательных и подзаконных нормативных правовых актов в рассматриваемой cфepe.

К числу законодательных актов, определяющих общие принципы, функции и систему защиты конституционного строя России в избирательном процессе, можно отнести: Конституцию Российской Федерации, Закон Российской Федерации от 5 марта 1992 г. «О безопасности», Федеральный закон от 25 июля 2002 г. № 114-Ф3 «О противодействии экстремистской деятельности», Федеральный закон от 6 марта 2006 г. № 35-Ф3 «О противодействии терроризму», конституции (уставы) субъектов Российской Федерации. Главенствующую роль в иерархии нормативных правовых актов, составляющих правовую основу защиты конституционного строя России в избирательном процессе, занимает Конституция Российской Федерации, которая имеет высшую юридическую силу,

${ }^{1}$ Международное правовое регулирование избирательного процесса рассмотрено в параграфе 3.1. 
прямое действие и применяется на всей территории России. Законы и иные правовые акты, принимаемые в России, не должны противоречить Конституции (часть 1 статьи 15). Права и свободы человека и гражданина могут быть ограничены федеральным законом только в той мере, в какой это необходимо в целях защиты основ конституционного строя, нравственности, здоровья, прав и законных интересов других лиц, обеспечения обороны страны и безопасности государства (часть 3 статьи 55). В соответствии с этими общими правовыми положениями и действуют субъекты защиты конституционного строя России в избирательном процессе. Приведенное конституционное положение также позволяет издавать законодательные акты, регулирующие отдельные аспекты защиты конституционного строя, имеющие отношение к выборам (например, федеральные конституционные законы «О чрезвычайном положении», «О военном положении» и другие) ${ }^{1}$.

Закон Российской Федерации «О безопасности» закрепляет правовые основы обеспечения безопасности личности, общества и государства, определяет систему безопасности и ее функции, устанавливает порядок организации и финансирования органов обеспечения безопасности, а также контроля и надзора за законностью их деятельности.

Федеральным законом «О противодействии экстремистской деятельности» определяются правовые и организационные основы противодействия экстремизму в целях защиты прав и свобод человека и гражданина, основ конституционного строя, обеспечения целостности и безопасности Российской Федерации, устанавливается юридическая ответственность за осуществление экстремистской деятельности.

Федеральный закон «О противодействии терроризму» устанавливает основные принципы противодействия терроризму, правовые и организационные

1 Федеральный конституционный закон от 30 мая 2001 г. № 3-ФК3 «О чрезвычайном положении» регламентирует ограничение права на участие в выборах и референдуме граждан Российской Федерации в условиях чрезвычайного положения (статья 14). В случае истечения в период действия чрезвычайного положения срока полномочий выборных органов и должностных лиц, срок полномочий указанных органов и лиц продлевается до прекращения действия чрезвычайного положения. Таким же образом, в соответствии с частью 4 статьи 7 Федерального конституционного закона от 30 января 2002 г. № 1-ФКЗ «О военном положении», на территории, на которой введено военное положение, референдумы и выборы в органы государственной власти и органы местного самоуправления не проводятся. 
основы профилактики терроризма и борьбы с ним, минимизации и (или) ликвидации последствий проявлений терроризма, а также правовые и организационные основы применения Вооруженных Сил Российской Федерации в борьбе с терроризмом.

Конституции и уставы субъектов Российской Федерации содержат предметы ведения субъекта Российской Федерации, гарантии прав и свобод человека и гражданина, основы организации государственной власти на территории субъекта Российской Федерации, положения об охране правопорядка и защите основ конституционного строя.

В группу законодательных актов, устанавливающих гарантии законности прохождения избирательного процесса, свободной реализации избирательных прав, а также обеспечивающих защиту демократических принципов и норм избирательного права (в том числе, путем закрепления юридической ответственности правонарушителей), входят Федеральный закон от 12 июня 2002 г. (в ред. от 22 апреля 2010 г.) «Об основных гарантиях избирательных прав и права на участие в референдуме граждан Российской Федерации», Федеральный закон от 10 января 2003 г. (в ред. от 22 апреля 2010 г.) «О выборах Президента Российской Федерации»; Федеральный закон от 10 января 2003 г. (в ред. от 25 декабря 2008 г.) «О Государственной автоматизированной системе Российской Федерации «Выборы»; Федеральный закон от 18 мая 2005 г. (в ред. от 22 апреля 2010 г.) № 51-Ф3 «О выборах депутатов Государственной Думы Федерального Собрания Российской Федерации». Ответственность за нарушение порядка организации и проведения выборов установлена Уголовным кодексом Российской Федерации от 13 июня 1996 г. (в ред. от 19 мая 2010 г.) № 63-Ф3, Кодексом Российской Федерации об административных правонарушениях от 30 декабря 2001 г. (в ред. от 19 мая 2010 г.) № 195-Ф3, законодательством субъектов Российской Федерации об административных правонарушениях. Порядок рассмотрения судами жалоб в связи с нарушением избирательных прав граждан регулируется Гражданским процессуальным кодексом Российской Федерации от 14 ноября 2002 г. (в ред. от 30 апреля 2010 г.) № 138-Ф3. 
Законодательные акты, регламентирующие правовой статус, задачи и возможные формы участия государственных (в том числе правоохранительных) органов и учреждений в защите конституционного строя России в избирательном процессе, включают: Закон Российской Федерации от 18 апреля 1991 г. (в ред. от 29 декабря 2009 г.) «О милиции», Закон Российской Федерации от 17 января 1992 г. (в ред. от 28 ноября 2009 г.) «О прокуратуре Российской Федерации», Федеральный закон от 3 апреля 1995 г. «О федеральной службе безопасности» (в ред. от 25 декабря 2008 г.), Федеральный закон от 10 июля 2002 г. (в ред. от 25 ноября 2009 г.) «О Центральном банке Российской Федерации (Банке России)». Данная группа законодательных актов определяет общие и частные задачи субъектов защиты конституционного строя России в процессе организации и проведения выборов, устанавливает функции и полномочия указанных субъектов в процессе решения стоящих перед ними задач, закрепляет порядок использования ими специальных сил и средств, порядок подчиненности и подотчетности, формы взаимодействия с другими государственными органами и учреждениями, механизм контроля.

Отдельную группу составляют подзаконные нормативные правовые акты. Среди подзаконных нормативных правовых актов федерального уровня, определяющих общие принципы, функции и систему защиты конституционного строя России в избирательном процессе, можно выделить: указы Президента Российской Федерации (Указ Президента Российской Федерации от 15 февраля 2006 г. (в ред. от 10 ноября 2009 г.) № 116 «О мерах по противодействию терроризму», Указ Президента Российской Федерации от 17 марта 2008 г. (в ред. от 21 октября 2008 г.) № 351 «О мерах по обеспечению информационной безопасности Российской Федерации при использовании информационнотелекоммуникационных сетей международного информационного обмена» и др.) и Постановления Правительства Российской Федерации (к примеру, Постановление Правительства Российской Федерации от 17 ноября 2007 года № 781 «Об утверждении Положения об обеспечении безопасности персональных данных при их обработке в информационных системах персональных данных»).

На уровне субъектов Российской Федерации общие принципы, функции и 
систему защиты конституционного строя в избирательном процессе закрепляют указы высших должностных лиц субъектов Российской Федерации о мерах по противодействию терроризму на территориях соответствующих субъектов Российской Федерации, об утверждении Положений о Советах Безопасности и антитеррористических комиссиях субъектов Российской Федерации ${ }^{1}$.

В число подзаконных нормативных правовых актов федерального уровня, устанавливающих гарантии законности прохождения избирательного процесса, свободной реализации избирательных прав, а также обеспечивающих защиту демократических принципов и норм избирательного права, входят Указ Президента Российской Федерации от 1 августа 1996 г. № 1134 «О мерах по обеспечению конституционных прав граждан на участие в выборах законодательного (представительного) органа государственной власти Сахалинской области», Указ Президента Российской Федерации от 29 февраля 2008 г. № 285 «Об утверждении Положения о выборах депутатов Законодательного Собрания Забайкальского края первого созыва», Указ Президента Российской Федерации от 29 февраля 2008 г. № 286 «Об утверждении Положения о выборах депутатов Законодательного Собрания Иркутской области первого созыва», Постановление Правительства Российской Федерации от 18 декабря 1995 г. № 1242 «О Федеральной целевой программе развития Государственной автоматизированной системы Российской Федерации «Выборы» на 1996-2000 годы» и др.

На региональном уровне данный блок подзаконных нормативных правовых актов представлен указами (постановлениями) высших должностных лиц субъектов Российской Федерации о мерах по обеспечению функционирования в субъектах Российской Федерации Государственной системы регистрации (учета) избирателей, участников референдума в Российской Федерации и другими нормативными документами, в той или иной мере регламентирующими

\footnotetext{
${ }^{1}$ См. Указ Главы Республики Северная Осетия-Алания от 4 мая 2007 г. № 90 «О мерах по противодействию терроризму на территории республики Северная Осетия-Алания»; указ Президента Республики Дагестан от 3 апреля 2006 г. № 26 «Об утверждении положения о Совете Безопасности Республики Дагестан»; Указ Президента Республики Дагестан от 24 апреля 2006 г. № 36a «О Республиканской антитеррористической комиссии».
} 
различные гарантии законности прохождения избирательного процесса, свободной реализации избирательных прав, а также обеспечивающими защиту демократических принципов и норм избирательного права. Примером могут служить Указ Главы Республики Коми от 28 марта 2006 г. № 37 «Об организации и осуществлении регистрации (учета) избирателей, участников референдума на территории Республики Коми»; Указ Президента Республики Татарстан от 1 марта 2006 г. № УП-78 «О мерах по обеспечению функционирования в Республике Татарстан Государственной системы регистрации (учета) избирателей, участников референдума в Российской Федерации» и др.

Последнюю группу нормативных актов в структуре нормативной правовой основы защиты конституционного строя России в избирательном процессе образуют подзаконные акты, регламентирующие правовой статус, задачи и возможные формы участия государственных (в том числе правоохранительных) органов и учреждений в защите конституционного строя России в условиях выборов.

На федеральном уровне основной массив занимают нормативные правовые акты Президента Российской Федерации (Указ Президента Российской Федерации от 23 марта 1995 г. (в ред. от 3 ноября 2004 г.) № 310 «О мерах по обеспечению согласованных действий органов государственной власти в борьбе с проявлениями фашизма и иных форм политического экстремизма в Российской Федерации», Указ Президента Российской Федерации от 4 июля 2001 г. (в ред. от 12 января 2010 г.) № 644 «О некоторых вопросах Министерства внутренних дел Российской Федерации», Указ Президента Российской Федерации от 11 августа 2003 г. (в ред. от 14 мая 2010 г.) № 960 «Вопросы Федеральной службы безопасности Российской Федерации», акты Правительства Российской Федерации (Постановление Правительства Российской Федерации от 30 сентября 2004 г. (в ред. от 9 марта 2010 г.) № 506 «Об утверждении Положения о Федеральной налоговой службе») и акты Центральной избирательной комиссии Российской Федерации (Постановление ЦИК Российской Федерации от 30 ноября 2001 г. № 144/1320-3 «О содействии Центральной избирательной комиссии, 
органов исполнительной власти, правоохранительных органов избирательным комиссиям субъектов Российской Федерации в организации проведения выборов», Постановление ЦИК Российской Федерации от 25 апреля 2007 г. (в ред. от 10 ноября 2009 г.) № 5/45-5 «О контрольно-ревизионной службе при Центральной избирательной комиссии Российской Федерации» и др.).

Особое место в регулировании вопросов координации действий избирательных комиссий, правоохранительных и иных государственных органов и учреждений в процессе организации и проведения выборов в России принадлежит постановлениям Правительства Российской Федерации о содействии избирательным комиссиям - Постановлению Правительства Российской Федерации от 25 августа 1999 г. № 937 «О содействии избирательным комиссиям в организации подготовки и проведения выборов депутатов Государственной Думы Федерального Собрания Российской Федерации», Постановлению Правительства Российской Федерации от 13 января 2000 г. № 32 «О содействии избирательным комиссиям в организации подготовки и проведения выборов Президента Российской Федерации», Постановлению Правительства Российской Федерации от 5 сентября 2003 г. № 555 «О мерах по содействию избирательным комиссиям в организации подготовки и проведения выборов депутатов Государственной Думы Федерального Собрания Российской Федерации и Президента Российской Федерации», Постановлению Правительства Российской Федерации от 17 сентября 2007 года № 589 «О мерах по оказанию содействия избирательным комиссиям в реализации их полномочий при подготовке и проведении выборов депутатов Государственной Думы Федерального Собрания Российской Федерации и Президента Российской Федерации» ${ }^{1}$.

\footnotetext{
1 Учитывая практику деления министерств по подведомственности между Президентом и Правительством, закрепленную в Указе Президента Российской Федерации от 12 мая 2008 г. (в ред. от 31 декабря 2008 г.) № 724 «Вопросы системы и структуры федеральных органов исполнительной власти», представляется необоснованным издание Правительством нормативных правовых актов, предписывающих осуществление какой-либо деятельности государственным органам, непосредственно подчиненным Президенту Российской Федерации. Соответствующие нормативные правовые акты должны издаваться либо главой государства, либо Правительством, но лишь в рамках официально делегированного Президентом Российской Федерации права.
} 
Сравнительное правовое исследование данных постановлений Правительства Российской Федерации позволяет выделить несколько основных тенденций нормативного правового регулирования деятельности субъектов защиты конституционного строя России в избирательном процессе.

1. За период принятия соответствующих нормативных правовых актов Правительства Российской Федерации (1999-2007) была усилена превентивная составляющая борьбы с противоправной агитационной деятельностью. В отличие от Постановлений Правительства Российской Федерации от 25 августа 1999 г. № 937 и от 13 января 2000 г. № 32, в которых речь шла только о пресечении противоправной агитационной деятельности (пункт 8 постановлений), подпункт «г» пункта 5 Постановления Правительства Российской Федерации от 5 сентября 2003 г. № 555 предписывает принятие мер по предотвращению изготовления подложных и незаконных предвыборных агитационных материалов и их изъятию, установлению изготовителей и распространителей указанных материалов, источников их оплаты, а подпункт «в» пункта 7 Постановления Правительства Российской Федерации от 17 сентября 2007 г. № 589 предусматривает, кроме изложенного, выявление участников противоправной агитационной деятельности и своевременное направление материалов в суд.

2. Расширен перечень субъектов противодействия противоправной агитационной деятельности и поставлены задачи противодействия экстремистской деятельности, в том числе возбуждающей социальную, расовую, национальную, религиозную ненависть и вражду. В Постановлениях Правительства Российской Федерации от 25 августа 1999 г. № 937 и от 13 января 2000 г. № 32 в качестве субъектов противодействия противоправной агитационной деятельности закреплены Министерство внутренних дел Российской Федерации и ФСБ России. В Постановлении Правительства Российской Федерации от 5 сентября 2003 г. № 555 (пункт 9) в перечень уполномоченных государственных органов дополнительно включены Министерство юстиции Российской Федерации и Министерство Российской Федерации по делам печати, телерадиовещания и средств массовых 
коммуникаций (в пункте 13 Постановления Правительства Российской Федерации от 17 сентября 2007 г. № 589 - Федеральная регистрационная служба и Федеральная служба по надзору в сфере массовых коммуникаций, связи и охраны культурного наследия). В Постановлениях Правительства о содействии избирательным комиссиям, принятых в 2003 и 2007 гг., выделено направление противодействия экстремистской агитационной деятельности.

3. Вырос объем и повысилось качество содержания нормативного материала. В нормативных правовых актах Правительства Российской Федерации о содействии избирательным комиссиям, принятых в 1999 и 2000 гг., присутствует правовой материал, непосредственно не относящийся к предмету нормативного регулирования. Например, Постановление Правительства Российской Федерации от 25 августа 1999 г. № 937 (пункт 18) определяло необходимость разработки комплекса мер по правовому обучению избирателей на 2000-2005 г., а Постановление Правительства Российской Федерации от 13 января 2000 г. № 32 (пункт 18) устанавливало обязанность полномочного представителя Правительства Российской Федерации в Чеченской Республике обеспечить координацию деятельности федеральных органов исполнительной власти по оказанию содействия избирательным комиссиям в организации подготовки и проведения выборов на территории Чеченской Республики. Построение нормативного материала в Постановлениях Правительства Российской Федерации от 5 сентября 2003 г. № 555 и от 17 сентября 2007 г. № 589 является более однородным.

4. Сфера действия указанных нормативных правовых актов Правительства Российской Федерации постепенно расширялась. Так, Постановления Правительства Российской Федерации от 25 августа 1999 г. № 937 и от 13 января 2000 г. № 32 не предполагали разработки органами исполнительной власти субъектов Российской Федерации комплекса организационно-технических мероприятий, связанных с подготовкой и проведением выборов, и обеспечения их выполнения. Целесообразность подобной деятельности органов исполнительной власти субъектов Российской Федерации закреплена в пункте 20 Постановления 
Правительства Российской Федерации от 5 сентября 2003 г. № 555 и пункте 28 Постановления Правительства Российской Федерации от 17 сентября 2007 г. № 589.

Ведомственные нормативные правовые акты других субъектов защиты конституционного строя в избирательном процессе (Министерства внутренних дел Российской Федерации, Министерства юстиции Российской Федерации, Министерства Российской Федерации по делам гражданской обороны, чрезвычайным ситуациям и ликвидации последствий стихийных бедствий, Министерства иностранных дел Российской Федерации, Министерства обороны Российской Федерации, Федеральной службы безопасности Российской Федерации, Федеральной миграционной службы, Федеральной налоговой службы) издаются, как правило, в виде приказов, которые регламентируют организацию и формы участия в деятельности по обеспечению законности и защиты конституционного строя в ходе конкретных избирательных кампаний. Компетентные органы издают их в пределах своих полномочий в соответствии с действующим российским законодательством. (В качестве примера можно привести Указание Генерального прокурора Российской Федерации от 28 сентября 2007 г. № 153/7 «Об организации прокурорского надзора за соблюдением законодательства о выборах депутатов Государственной Думы Федерального Собрания Российской Федерации», Приказ Генеральной прокуратуры Российской Федерации от 7 декабря 2007 г. № 195 «Об организации прокурорского надзора за исполнением законов, соблюдением прав и свобод человека и гражданина», Приказ Министра внутренних дел Российской Федерации от 21 февраля 2005 г. № 108 «Об объявлении Соглашения о взаимодействии Центральной избирательной комиссии Российской Федерации и Министерства внутренних дел Российской Федерации», Приказ Министра внутренних дел Российской Федерации от 26 сентября 2007 г. № 835 «О порядке исполнения органами внутренних дел Российской Федерации представлений избирательных комиссий», Приказ Федеральной налоговой службы от 10 августа 2007 г. № ММ-3-04/474 «Об организации работы по оказанию содействия 
Центральной избирательной комиссии Российской Федерации в проверке достоверности сведений о размере и об источниках доходов, имуществе, принадлежащем кандидату на праве собственности, о вкладах в банках, ценных бумагах, представляемых кандидатами в депутаты Государственной Думы Федерального Собрания Российской Федерации пятого созыва» и др.) ${ }^{1}$.

На уровне субъектов Российской Федерации главенствующую роль среди подзаконных актов, регламентирующих правовой статус, задачи и возможные формы участия государственных (в том числе правоохранительных) органов и учреждений в защите конституционного строя в избирательном процессе, играют постановления высших органов исполнительной власти субъектов Российской Федерации (реже - указы высших должностных лиц субъектов Российской Федерации) о мерах по содействию избирательным комиссиям в организации подготовки и проведения выборов депутатов Государственной Думы Федерального Собрания Российской Федерации и Президента Российской Федерации, депутатов законодательных органов государственной власти субъектов Российской Федерации, глав муниципальных образований и депутатов представительных органов муниципальных образований ${ }^{2}$, а также постановления избирательных комиссий субъектов Российской Федерации о контрольноревизионных службах при избирательных комиссиях различного уровня; о мерах по обеспечению безопасности информации, обрабатываемой в ГАС «Выборы» в

\footnotetext{
${ }^{1}$ Ведомственные нормативные правовые акты органов федеральной службы безопасности в данной сфере являются секретными и в работе не рассматриваются.

${ }^{2}$ См. Постановление Кабинета Министров Республики Татарстан от 12 октября 2007 г. № 550 «О содействии избирательным комиссиям в организации подготовки и проведения выборов депутатов Государственной Думы Федерального Собрания Российской Федерации и Президента Российской Федерации»; Постановление Правительства Республики Хакасия от 14 сентября 2005 г. № 288 «О мерах по содействию избирательным комиссиям в Республике Хакасия в организации подготовки и проведения выборов глав вновь образованных муниципальных образований и депутатов представительных органов муниципальных образований первого созыва в Республике Хакасия»; Постановление Правительства Москвы от 15 марта 2005 г. № 139-ПП «Об оказании содействия в организационном и материально-техническом обеспечении повторных и дополнительных выборов депутатов муниципальных собраний внутригородских муниципальных образований в г. Москве»; Указ Президента Удмуртской Республики от 1 августа 2006 года № 113 «О содействии избирательным комиссиям в подготовке и проведении выборов депутатов представительных органов муниципальных районов» и др.
} 
избирательной комиссии субъекта Российской Федерации ${ }^{1}$ и др.

Все перечисленные нормативные правовые акты, регулирующие отношения по защите конституционного строя России в избирательном процессе, функционируют как единая взаимосвязанная система.

Помимо рассмотренных вопросов правового регулирования основополагающее значение для нормативной правовой основы защиты конституционного строя в избирательном процессе имеют юридические ограничения, определяющие пределы государственно-властного вмешательства в сферу общественных отношений, возникающих в связи с организацией и проведением выборов в России. Согласно пункту 12 статьи 20 Федерального закона от 12 июня 2002 г. № 67-Ф3 вмешательство государственных органов, их должностных лиц, организаций и граждан в деятельность избирательных комиссий запрещается. Подобного рода деятельность является незаконной и влечет за собой юридическую ответственность 2 .

Участие уполномоченных правоохранительных органов в защите конституционного строя в избирательном процессе тоже имеет свои пределы. Статья 5 Федерального закона «Об оперативно-розыскной деятельности» гласит: «Органам (должностным лицам), осуществляющим оперативно-розыскную деятельность, запрещается... проводить оперативно-розыскные мероприятия в интересах какой-либо политической партии, общественного и религиозного объединения; принимать негласное участие в работе федеральных органов государственной власти, органов государственной власти субъектов Российской Федерации и органов местного самоуправления, а также в деятельности зарегистрированных в установленном порядке и незапрещенных политических

${ }^{1}$ См. Постановление Центральной избирательной комиссии Республики Башкортостан от 20 августа 2008 года № Ц4/3-4 «О Контрольно-ревизионной службе при Центральной избирательной комиссии Республики Башкортостан»; Постановление Центральной избирательной комиссии Республики Саха (Якутия) от 17 сентября 2007 г. № 41/5-3 «О примерном Положении о контрольно-ревизионной службе при территориальной избирательной комиссии, избирательной комиссии муниципального образования»; Постановление избирательной комиссии Магаданской области от 17 ноября 2005 г. № 58/281 «Об организации деятельности муниципальных избирательных комиссий и создаваемых при них контрольно-ревизионных служб по осуществлению финансового контроля»; Постановление избирательной комиссии Калужской области» от 28 марта 2007 г. № 28/6-III «О мерах по обеспечению безопасности информации, обрабатываемой в ГАС РФ «Выборы» в избирательной комиссии Калужской области» и др.

${ }^{2}$ См. Рос. газ. 2002. 15 июня; 2002. 28 сентября; 2003. 25 июня; 2003. 8 июля; 2004. 9 июня; 2004. 14 августа; 2004. 31 августа; 2004. 15 декабря; 2005. 2 июля; 2005. 26 июля; 2006. 15 июля; 2006. 27 июля; 2006. 7 декабря; 2007. 10 января; 2007. 2 февраля; 2007. 6 марта; 2007. 24 апреля; 2007. 11 мая; 2007. 1 августа; 2008. 25 июля; 2008. 28 ноября; 2008. 31 декабря; 2009. 11 февраля; 2009. 8 апреля; 10 июня; 2010. 26 апреля. 
партий, общественных и религиозных объединений в целях оказания влияния на характер их деятельности» ${ }^{1}$.

Дополнительные гарантии политической нейтральности закреплены в отношении органов федеральной службы безопасности. Статья 2 Федерального закона «О федеральной службе безопасности» запрещает создание и деятельность в органах федеральной службы безопасности политических партий, общественных движений, преследующих политические цели, а также ведение политической агитации и предвыборных кампаний².

В случае нарушения сотрудниками государственных (в том числе, правоохранительных) органов избирательных прав граждан или необоснованного вмешательства в деятельность избирательных комиссий руководитель соответствующего органа, прокурор или судья обязаны принять меры по восстановлению этих прав, возмещению причиненного ущерба и привлечению виновных к ответственности.

Нормативная правовая основа защиты конституционного строя в избирательном процессе строится с учетом необходимости строгого соблюдения политических прав граждан России, установленной законом процедуры прохождения избирательного процесса, исключения возможности негативного воздействия на выборы изнутри и извне в сочетании с приоритетом обеспечения защиты конституционного строя в избирательном процессе.

\section{2. Конституционно-правовой механизм защиты конституционного строя России в избирательном процессе}

Конституционно-правовой механизм защиты конституционного строя России представляет собой целостную, взаимосвязанную, юридически оформленную совокупность объектов защиты, субъектов и форм взаимодействия между ними, функционально обеспечивающую народовластие, верховенство и

\footnotetext{
${ }^{1}$ См. СЗ РФ. 1995. № 33. Ст. 3349; 1997. № 29. Ст. 3502; 1998. № 30. Ст. 3613; 1999. № 2. Ст. 233; 2001. № 13. Ст. 1140; 2003. № 2. Ст. 167; 2004. № 27. Ст. 2711; 2004. № 35. Ст. 3607; 2005. № 49. Ст. 5128; 2007. № 31. Ст. 4008; 2008. № 18. Ст. 1941; 2008. № 52 (ч. 1). Ст. 6235; 2008. № 52 (ч. 1). Ст. 6248.

2 См. Рос. газ. 1995. 12 апреля; 2000. 6 января; 2002. 30 июля; 2003. 14 января; 2003. 1 июля; 2004. 31 августа; 2005. 11 марта; 2006. 21 апреля; 2006. 29 июля; 2007. 1 августа; 2007. 8 декабря; 2008. 30 декабря.
} 
прямое действие Конституции Российской Федерации на всей территории государства, территориальную целостность и суверенитет, политический и идеологический плюрализм, развитие конституционного контроля за государственными и муниципальными органами, привлечение к ответственности за нарушение конституционных норм.

Некоторые авторы (Ю.Л. Шульженко) включают в структуру механизма защиты (охраны) Конституции такие элементы, как особый порядок принятия и изменения Конституции, конституционный контроль и надзор, толкование Конституции ${ }^{1}$. Н.M. Колосова добавляет к указанным составляющим стабильность, непосредственное действие Конституции, эффективность конституционных норм². Такая точка зрения представляется дискуссионной, поскольку речь идет, с одной стороны, о характерных чертах Конституции, а с другой, о правоприменении как одной из форм реализации конституционных норм.

В широком смысле к объектам защиты конституционного строя России можно отнести: политико-правовые основы организации государства (демократизм, государственный суверенитет, конституционная форма правления и государственного устройства, верховенство права); идеологические основы общества (политический и идеологический плюрализм, светский характер государства); социальные основы общества (общественная стабильность, гражданский мир, защищенность и безопасность граждан, конституционные права и свободы); институты политической системы и конституционный порядок их организации и деятельности. В узком смысле объекты защиты конституционного строя России включают: политико-правовые основы организации государства, институты политической системы и конституционный порядок их организации и деятельностиํ․

\footnotetext{
1 См.: Шульженко Ю.Л. Вопросы правовой охраны Конституции в дореволюционной России / Конституционный строй. Вып. 4. М.: ИГП АН, 2003. С. 4-5.

${ }^{2}$ См.: Конституционное законодательство России / Под ред. Ю.А. Тихомирова. М.: Городец, 1999. С. 382.

3 Учитывая, что конституционный строй рассматривается в монографии как способ организации государства, закрепленный в Конституции, в работе проведено исследование объектов защиты конституционного строя в узком смысле. Правовое обеспечение защиты конституционного строя в избирательном процессе представлено с учетом данной оговорки.
} 
Субъектами защиты конституционного строя России являются федеральные органы государственной власти и органы государственной власти субъектов Российской Федерации, осуществляющие в пределах своей компетенции меры по защите конституционного строя России. Исходя из целей использования и специфики возникающих при этом правоотношений, субъекты защиты конституционного строя применяют в своей деятельности комплекс различных мep:

- пресекательные меры, направленные на принудительное прекращение противоправных действий (бездействия), создающих угрозу конституционному строю;

- меры по локализации и устранению возникших и существующих угроз конституционному строю;

- меры юридической ответственности, направленные на привлечение правонарушителей к ответственности за совершение действий (бездействия), создающих угрозу конституционному строю.

Характер угроз конституционному строю, компетенция субъектов защиты конституционного строя, наличие соответствующих сил и средств определяют направления деятельности уполномоченных субъектов защиты конституционного строя и формы взаимодействия между ними ${ }^{1}$.

Конституционно-правовой механизм защиты конституционного строя в избирательном процессе является частью конституционного механизма защиты конституционного строя, при помощи которой осуществляется эффективное воздействие на общественные отношения, возникающие в связи с формированием органов публичной власти путем выборов, обеспечивается реализация конституционных прав участников избирательного процесса, защита

1 См.: Алексеев Н.А. Организационно-правовые основы взаимодействия органов внутренних дел с избирательными комиссиями. Дис. ... канд. юрид. наук. М., 2001. 175 с; Глушенко П.П., Гнетов А.В. Механизм использования избирательными комиссиями и правоохранительными органами правовых методов, средств и способов обеспечения реализации и защиты избирательных прав граждан / Проблемы дальнейшего совершенствования механизма управления правозащитной деятельностью. Материалы Междунар. науч.-практ. конф. СПб, 2007. С. 89-110; Климова Ю.Н. Взаимодействие избирательной комиссии с правоохранительными органами при обеспечении законности и правопорядка на территории избирательного округа // Вестник ЦИК России. 2006. № 11. 
демократических принципов и норм избирательного права, легитимация избирательного процесса.

Конституционно-правовой механизм защиты конституционного строя в избирательном процессе имеет ряд особенностей:

- единая направленность его элементов на достижение основной цели предотвращения и устранения негативных явлений в области организации государственной власти и управления, закрепленной конституцией;

- четкая внутренняя организация механизма (единая цель конституционноправового механизма согласует и интегрирует все элементы механизма);

- адекватность применяемых правовых средств для достижения социально значимой цели воздействия на общественные отношения (защита конституционного строя возможна лишь с помощью допустимых и достаточных правовых средств);

- взаимосвязь с политикой (в функционировании конституционноправового механизма защиты конституционного строя в избирательном процессе выражается политика правящих социальных групп, заинтересованных в сохранении и укреплении своей власти в обществе);

- способность механизма к развитию (обусловлена динамикой общественных отношений, возникающих в условиях выборов).

Конституционно-правовой механизм защиты конституционного строя в избирательном процессе включает в себя несколько подсистем: нормативную (нормативно-правовая основа защиты конституционного строя в избирательном процессе); институциональную (субъекты защиты конституционного строя в избирательном процессе); функционально-коммуникативную (отношения между субъектами).

Нормативная подсистема конституционно-правового механизма защиты конституционного строя в избирательном процессе представляет собой взаимосвязанную совокупность конституционных положений, федеральных законов, нормативных правовых актов федеральных органов государственной власти, законодательных и подзаконных актов субъектов Российской Федерации, 
с помощью которой осуществляется правовое регулирование защиты конституционного строя в процессе организации и проведения выборов в Российской Федерации.

Институциональную подсистему образуют уполномоченные государственные органы и учреждения, осуществляющие в рамках предмета своего ведения защиту конституционного строя ${ }^{1}$.

Функционально-коммуникативную подсистему конституционно-правового механизма защиты конституционного строя в избирательном процессе составляют отношения, которые выражают характер связей между субъектами защиты конституционного строя и сущность политического режима.

Для полного представления о конституционно-правовом механизме защиты конституционного строя в избирательном процессе следует рассмотреть его функции.

1. Функция целеполагания обеспечивает определение целей и задач защиты конституционного строя в избирательном процессе, является основой для выработки государственных программ защиты конституционного строя в условиях выборов.

2. Регулятивная функция выражается в устойчивом, динамичном и эффективном упорядочении общественных отношений в соответствии с потребностями социально-политического развития и стратегическими установками правящих социальных групп. Она обеспечивает правомерное поведение участников политического и избирательного процессов.

3. Оценочная функция проявляется в оценке поведения участников политического и избирательного процессов с точки зрения его правомерности или противоправности.

${ }^{1}$ См.: Бондарь Н.С. Конституционный строй Российской Федерации и роль Конституционного Суда в его защите // Современный конституционализм. Тирасполь, 2006. № 1. С. 20-31; Коровинских Д.С., Доронина О.Н. Система правовой охраны Конституции Российской Федерации // Конституционное и муниципальное право. 2005. № 5. С. 10-19; Осипян C. Президентская власть и защита Конституции Российской Федерации (проблемы конституционного контроля и конституционного надзора) // Право и жизнь. 1998. № 15. С. 50-69; Плеханова Л.Н. Президент Российской Федерации в системе органов правовой охраны Конституции Российской Федерации. Автореф. дис. ...канд. юрид. наук. Томск, 2004. 26 с. 
4. Охранительная функция заключается в охране положительных и вытеснении негативных общественно-политических явлений, восстановлении нарушенных конституционных прав участников политического и избирательного процессов.

Путем реализации указанных функций конституционно-правового механизма защиты конституционного строя в избирательном процессе обеспечивается демократическое развитие политической и избирательной систем, безопасное осуществление избирательного процесса. Неспособность осуществления конституционно-правовым защиты конституционного строя в избирательном процессе своих функций влечет за собой дестабилизацию конституционного строя и политические кризисы.

Конституционно-правовой механизм защиты конституционного строя в избирательном процессе имеет исключительное значение для политической системы любого демократического общества. Он позволяет регулярно формировать свободно избранные органы народного представительства, исключает монополию на власть и огосударствление общественно-политических организаций, обеспечивает соблюдение конституционных прав участников избирательного процесса, является гарантом законности избирательных процедур. Совершенствование данного механизма укрепляет суверенитет государства, повышает общественно-политическую стабильность и доверие населения к власти, стимулирует политическую активность участников выборов.

Как уже отмечалось выше, защита конституционного строя России в избирательном процессе зависит от эффективной деятельности государственных органов и учреждений. Можно назвать их субъектами защиты конституционного строя в избирательном процессе. Все эти субъекты выступают от имени государства и образуют институциональную подсистему конституционноправового механизма защиты конституционного строя в избирательном процессе. В рамках компетенции они участвуют в решении разнообразных задач, связанных с защитой конституционного строя, в том числе и в условиях выборов. При реализации своих полномочий по предмету ведения субъекты защиты конституционного строя в избирательном процессе активно взаимодействуют. В 
то же время каждый уполномоченный субъект выполняет ряд свойственных только ему функций с использованием специфических сил и средств, форм и методов деятельности и, таким образом, участвует в защите конституционного строя в избирательном процессе. В соответствии с функциональным назначением субъекты защиты конституционного строя в избирательном процессе могут быть наделены правом издавать нормативные правовые и правоприменительные акты.

Субъекты защиты конституционного строя в избирательном процессе можно классифицировать на компетентные государственные органы (обладающие властными полномочиями) и компетентные учреждения (подобными полномочиями не наделены).

К числу компетентных государственных органов - субъектов защиты конституционного строя в избирательном процессе необходимо отнести Президента Российской Федерации, Федеральное Собрание Российской Федерации, Правительство Российской Федерации, органы государственной власти субъектов Российской Федерации, органы федеральной службы безопасности, избирательные комиссии, суды, органы прокуратуры, налоговые органы, органы юстиции, органы внутренних дел, органы Федеральной миграционной службы, органы Министерства иностранных дел Российской Федерации, органы Министерства по делам гражданской обороны, чрезвычайным ситуациям и ликвидации последствий стихийных бедствий, воинские формирования и органы Министерства обороны Российской Федерации. В группу компетентных учреждений - субъектов защиты конституционного строя в избирательном процессе входят учреждения Центрального банка Российской Федерации, территориальные банки и филиалы Сберегательного банка Российской Федерации.

По территориальным пределам деятельности субъекты защиты конституционного строя в избирательном процессе могут быть классифицированы на высиие (Президент Российской Федерации, Федеральное Собрание Российской Федерации, Правительство Российской Федерации, Конституционный суд Российской Федерации, Верховный суд Российской Федерации), центтральные (Центральная избирательная комиссия Российской Федерации, Генеральная прокуратура Российской Федерации, Федеральная 
служба безопасности Российской Федерации, Министерство внутренних дел Российской Федерации, Министерство иностранных дел Российской Федерации, Министерство Российской Федерации по делам гражданской обороны, чрезвычайным ситуациям и ликвидации последствий стихийных бедствий, Министерство юстиции Российской Федерации, Министерство обороны Российской Федерации, Федеральная налоговая служба, Федеральная миграционная служба, Центральный банк Российской Федерации), региональные (органы законодательной, исполнительной и судебной власти субъектов Российской Федерации, избирательные комиссии субъектов Российской Федерации, прокуратуры субъектов Российской Федерации, территориальные банки Сберегательного банка Российской Федерации, территориальные органы уполномоченных федеральных органов исполнительной власти) и местные (избирательные комиссии муниципальных образований, территориальные и участковые комиссии, городские и районные органы внутренних дел, юстиции, прокуратуры, филиалы Сберегательного банка Российской Федерации и др.).

По объему компетенции можно выделить: субъекты общей компетенции, определяющие направления деятельности государства по защите конституционного строя в избирательном процессе, уполномоченные рассматривать не только вопросы организации и осуществления избирательного процесса, но и вопросы защиты конституционного строя в рассматриваемой сфере (Президент Российской Федерации, Федеральное Собрание Российской Федерации, Правительство Российской Федерации, органы государственной власти субъектов Российской Федерации), а также субъекты специальной компетенции (органы федеральной службы безопасности, избирательные комиссии, суды, органы прокуратуры, налоговые органы, учреждения и филиалы Центрального банка Российской Федерации и Сбербанка России, органы юстиции, органы внутренних дел, органы Федеральной миграционной службы, органы Министерства по делам гражданской обороны, чрезвычайным ситуациям и ликвидации последствий стихийных бедствий, органы Министерства иностранных дел Российской Федерации, воинские формирования и органы 
Министерства обороны Российской Федерации), осуществляющие деятельность по специальному предмету ведения ${ }^{1}$.

В свою очередь, особенности правосубъектности позволяют выделить: субъекты, непосредственно осуществляющие защиту конституционного строя в избирательном процессе (высшие федеральные и региональные органы государственной власти, суды и органы федеральной службы безопасности), и субъекты, содействующие защите конституционного строя в избирательном процессе (избирательные комиссии, органы прокуратуры, налоговые органы, учреждения Центрального банка Российской Федерации и филиалы Сбербанка России, органы юстиции, органы внутренних дел, органы Министерства иностранных дел Российской Федерации, органы Министерства по делам гражданской обороны, чрезвычайным ситуациям и ликвидации последствий стихийных бедствий, воинские формирования и органы Министерства обороны Российской Федерации).

Следует различать субъекты защиты конституиионного строя 6 избирательном процессе и субъекты обеспечения безопасности выборов. Если деятельность субъектов защиты конституционного строя в избирательном процессе направлена на защиту основ конституционного строя, государственного суверенитета и территориальной целостности в условиях выборов, проходящих в Российской Федерации, то деятельность субъектов обеспечения безопасности выборов носит локальный характер и направлена лишь на выявление, предупреждение и пресечение конкретных правонарушений в ходе отдельной избирательной кампании. Далеко не каждый субъект обеспечения безопасности выборов является субъектом защиты конституционного строя в избирательном процессе. Например, кандидаты на выборные должности, политические партии и их региональные отделения, службы безопасности кандидатов, объединения избирателей могут выступать в качестве субъектов обеспечения безопасности выборов, но субъектами защиты конституционного строя в избирательном процессе они не являются, поскольку не обладают соответствующими правомочиями, материальными ресурсами, правом издавать нормативные

\footnotetext{
${ }^{1}$ Далее по тексту - субъекты общей компетенции и субъекты специальной компетенции.
} 
правовые и правоприменительные акты, легальной возможностью осуществлять меры принудительного характера.

Главенствующее место среди субъектов защиты конституционного строя в избирательном процессе занимает Президент Российской Федерации.

Президент осуществляет общее руководство подведомственными государственными органами, осуществляющими защиту конституционного строя в избирательном процессе (ФСБ России, МВД России, ФМС России, МЧС России, Министерство юстиции Российской Федерации, Министерство иностранных дел Российской Федерации, Министерство обороны Российской Федерации) ${ }^{1}$.

Президент назначает пять членов Центральной избирательной комиссии Российской Федерации ${ }^{2}$.

Президент обладает правом законодательной инициативы в части реформирования избирательной системы и системы защиты конституционного строя Российской Федерации ${ }^{3}$ В пределах компетенции глава государства издает нормативные правовые акты, регламентирующие отношения в сфере выборов в Российской Федерации ${ }^{4}$. Так, в связи с отсутствием необходимого кворума и невозможностью принятия в этих условиях законов о выборах депутатов законодательных органов государственной власти ряда субъектов Российской Федерации Президент Российской Федерации принимал меры по обеспечению

\footnotetext{
${ }^{1}$ Перечень федеральных органов исполнительной власти, которыми непосредственно руководит Президент Российской Федерации, закреплен в Указе Президента Российской Федерации от 12 мая 2008 г. (с изм. от 31 декабря 2008 г.) № 724 «Вопросы системы и структуры федеральных органов исполнительной власти». Следует отметить, что правомерность изъятия указанных министерств и ведомств из юрисдикции Правительства Российской Федерации как конституционного высшего органа исполнительной власти, практика деления отраслевых органов исполнительной власти по подведомственности между Президентом и Правительством вызывают сомнение.

${ }^{2}$ См. пункт 4 статьи 21 Федерального закона от 12 июня 2002 г. № 67-Ф3.

3 См. Указ Президента Российской Федерации от 20 декабря 1993 г. № 2227 «O мерах по совершенствованию избирательной системы в Российской Федерации» // Собрание актов Президента и Правительства РФ. 1993. № 52. Ст. 5060; Указ Президента Российской Федерации от 11 марта 2003 г. (в ред от 7 августа 2004 г.) № 308 «О мерах по совершенствованию государственного управления в области безопасности Российской Федерации» // СЗ РФ. 2003. № 12. Ст. 1101.

4 Например, выборы депутатов Государственной Думы Федерального Собрания Российской Федерации первого созыва проводились в соответствии с Положением о выборах депутатов Государственной Думы Федерального Собрания Российской Федерации, утвержденным Указом Президента Российской Федерации от 1 октября 1993 г. № 1557. См. также Указ Президента Российской Федерации от 17 сентября 1995 г. № 951 «О выборах в органы государственной власти субъектов Российской Федерации и органы местного самоуправления».
} 
конституционных прав граждан на участие в выборах ${ }^{1}$. После образования в составе Российской Федерации новых субъектов Российской Федерации Президент принял меры по обеспечению избирательных прав граждан в части организации и проведения выборов, не урегулированных законодательством о выборах 2 .

Президентом утверждена Стратегия национальной безопасности Российской Федерации до 2020 года (до ее принятия действовала Концепция национальной безопасности Российской Федерации), представляющая собой официально признанную систему стратегических приоритетов, целей и мер в области внутренней и внешней политики, определяющих состояние национальной безопасности и уровень устойчивого развития государства на долгосрочную перспективу. В Стратегии национальной безопасности сформулированы важнейшие направления государственной политики Российской Федерации ${ }^{3}$.

Президент вправе обратиться в Конституционный Суд Российской Федерации с запросом о соответствии Конституции Российской Федерации федеральных законов, нормативных правовых актов Президента Российской Федерации, Совета Федерации, Государственной Думы, Правительства Российской Федерации, конституций республик, уставов, а также законов и иных нормативных правовых актов субъектов Российской Федерации, регулирующих общественные отношения в сфере выборов.

Глава государства обращается с Посланиями к Федеральному Собранию Российской Федерации, в которых формулируются приоритетные направления

1 См. Указ Президента Российской Федерации от 11 апреля 1996 г. № 528 «О мерах по обеспечению конституционных прав граждан на участие в выборах законодательного (представительного) органа государственной власти Тульской области», Указ Президента Российской Федерации от 17 июля 1996 г. № 1038 «О мерах по обеспечению конституционных прав граждан на участие в выборах законодательного (представительного) органа государственной власти Кемеровской области», Указ Президента Российской Федерации от 1 августа 1996 г. № 1134 «О мерах по обеспечению конституционных прав граждан на участие в выборах законодательного (представительного) органа государственной власти Сахалинской области».

${ }^{2}$ См. Указ Президента Российской Федерации от 29 февраля 2008 г. № 285 «Об утверждении Положения о выборах депутатов Законодательного Собрания Забайкальского края первого созыва», Указ Президента Российской Федерации от 29 февраля 2008 г. № 286 «Об утверждении Положения о выборах депутатов Законодательного Собрания Иркутской области первого созыва».

${ }^{3}$ См. Указ и.о. Президента Российской Федерации от 10 января 2000 г. № 24 «О Концепции национальной безопасности Российской Федерации» (Утратил силу); Указ Президента Российской Федерации от 12 мая 2009 г. № 537 «Об утверждении Стратегии национальной безопасности Российской Федерации до 2020 года». По своей правовой природе Концепция национальной безопасности Российской Федерации и Стратегия национальной безопасности Российской Федерации до 2020 года представляют собой политико-правовые документы, поэтому в формате нормативной правовой основы защиты конституционного строя в избирательном процессе они не рассматриваются. 
развития политической системы российского общества и пути совершенствования избирательного законодательства. Так, в Послании Федеральному Собранию Российской Федерации 5 ноября 2008 г., Президент Российской Федерации предложил принять меры по дальнейшему повышению уровня и качества народного представительства во власти ${ }^{1}$ :

1) дать гарантии представительства избирателям, проголосовавшим за так называемые «малые» партии (партии, получившие от 5 до 7 \% голосов)²;

2) предоставить исключительное право выдвижения кандидатур руководителей исполнительной власти субъектов Российской Федерации только партиям, набравшим наибольшее число голосов на региональных выборах ${ }^{3}$;

3) отменить денежный залог на выборах всех уровней ${ }^{4}$ и освободить от сбора подписей политические партии, сумевшие набрать на выборах в Государственную Думу Федерального Собрания Российской Федерации более 5 \% голосов либо создавшие фракции в более чем трети региональных парламентов ${ }^{5}$;

4) формировать Совет Федерации Федерального Собрания Российской Федерации только из числа лиц, избранных в представительные органы власти, и депутатов местного самоуправления соответствующего субъекта Российской Федерации;

1 Полный текст Послания Президента Российской Федерации Федеральному Собранию Российской Федерации см. Рос. газ. 2008. 6 ноября.

2 По инициативе Президента Российской Федерации был принят Федеральный закон от 12 мая 2009 г. № 94Ф3 «О внесении изменений в отдельные законодательные акты Российской Федерации в связи с повышением представительства избирателей в Государственной Думе Федерального Собрания Российской Федерации» // Рос газ. 2009. 15 мая.

3 Данный механизм внесения предложений о кандидатурах на должность высшего должностного лица субъекта Российской Федерации был закреплен Федеральным законом от 5 апреля 2009 г. № 41-Ф3 «О внесении изменений в Федеральный закон «Об общих принципах организации законодательных (представительных) и исполнительных органов государственной власти субъектов Российской Федерации» и Федеральный закон «О политических партиях». В существующем виде он усиливает доминирующее положение правящей партии и создает предпосылки для сращивания партийного и государственного аппаратов. С позиций демократического совершенствования конституционно-правового законодательства более обоснованным являлось бы законодательное закрепление необходимости поддержки кандидатур на должность высшего должностного лица субъекта Российской Федерации не менее чем двумя политическими партиями, списки кандидатов которых получили наибольшее число голосов избирателей на основании ближайших результатов выборов.

${ }^{4}$ По инициативе Президента Российской Федерации был принят Федеральный закон от 9 февраля 2009 г. № 3-Ф3 «О внесении изменений в отдельные законодательные акты Российской Федерации в связи с отменой избирательного залога при проведении выборов».

${ }^{5}$ См. Федеральный закон от 3 июня 2009 г. № 108-Ф3 «О внесении изменений в отдельные законодательные акты Российской Федерации в связи с сокрашением количества подписей избирателей в поддержку выдвижения федеральных списков кандидатов на выборах депутатов Государственной Думы Федерального Собрания Российской Федерации и уточнением оснований для регистрации кандидатов, списков кандидатов на выборах в органы государственной власти и органы местного самоуправления» // Рос. газ. 2009. 10 июня. 
5) поэтапно снизить минимальное количество членов организации, требуемое для регистрации новой политической партии ${ }^{1}$;

6) производить ротации руководящего партийного аппарата (одно и то же лицо не может занимать определенную руководящую должность в аппарате партии дольше определенного срока) ${ }^{2}$;

7) усилить представительство политических партий и общественных организаций в представительных органах местного самоуправления, предоставить указанным органам возможность контролировать, а при необходимости - и отстранять от должности руководителей муниципалитетов;

8) создать четко сформулированные гарантии освещения работы парламентских партий в государственных СМИ³.

В Послании Федеральному Собранию Российской Федерации 12 ноября 2009 г. Президент России предложил уделить особое внимание укреплению демократических институтов на региональном уровне и сформулировал новую концепцию реформирования избирательной системы ${ }^{4}$ Глава государства предложил:

- ввести единый критерий установления численности депутатов органов законодательной власти субъектов Российской Федерации

- закрепить гарантии представительства в законодательных органах субъектов Российской Федерации политических партий, получивших на региональных выборах более 5 \% голосов избирателей ${ }^{1}$;

1 Данное предложение Президента реализовано в Федеральном Законе от 28 апреля 2009 г. № 75-Ф3 «О внесении изменений в Федеральный закон «О политических партиях» в связи с поэтапным снижением минимальной численности членов политических партий» // Рос. газ. 2009. 5 мая.

2 Данное предложение реализовано в Федеральном Законе от 28 апреля 2009 г. № 75-Ф3 «О внесении изменений в Федеральный закон «О политических партиях» в связи с поэтапным снижением минимальной численности членов политических партий» // Рос. газ. 2009. 5 мая.

${ }^{3}$ См. По инициативе Президента Российской Федерации был принят Федеральный закон от 12 мая 2009 г. № 95-Ф3 «О гарантиях равенства парламентских партий при освещении их деятельности государственными общедоступными телеканалами и радиоканалами» // Рос. газ. 2009. 15 мая.

${ }^{4}$ См. Рос. газ. 2009. 13 ноября.

5 См. Федеральный закон от 5 апреля 2010 г. № 42-Ф3 «О внесении изменений в статью 4 Федерального закона «Об общих принципах организации законодательных (представительных) и исполнительных органов государственной власти субъектов Российской Федерации» в связи с установлением требований к числу депутатов законодательного (представительного) органа государственной власти субъекта Российской Федерации // СЗ РФ. 2010. № 15. Ст. 1738. 
- отказаться в перспективе от сбора подписей как метода допуска партии к выборам;

- гарантировать возможность постоянного участия непарламентских партий в работе Центральной и региональных избирательных комиссий루

- четко урегулировать процедуры досрочного голосования на местных выборах ${ }^{3}$;

- принять необходимые меры для предотвращения незаконных манипуляций с открепительными удостоверениями ${ }^{4}$;

- предоставить всем партиям равные возможности в использовании муниципальных зданий для проведения агитационной работы в ходе избирательных кампаний ${ }^{5}$;

- принять во всех субъектах Российской Федерации законы о гарантиях равного освещения в СМИ деятельности партий, представленных в региональных парламентах ${ }^{6}$;

- активизировать работу по техническому переоснащению избирательной системы.

Представляется, что данные предложения Президента Российской Федерации направлены на демократизацию политической системы российского общества и укрепление доверия российских граждан к действующей власти.

1 См. Федеральный закон от 22 апреля 2010 г. № 63-Ф3 «О внесении изменений в отдельные законодательные акты Российской Федерации в связи с повышением представительства избирателей в законодательных (представительных) органах государственной власти субъектов Российской Федерации и освобождении от сбора подписей избирателей политических партий, списки кандидатов которых получили депутатские мандаты в законодательных (представительных) органах государственной власти субъектов Российской Федерации» // СЗ РФ. 2010. № 17. Ст. 1986.

${ }^{2}$ См. Приложение.

${ }^{3}$ См. Федеральный закон от 31 мая 2010 г. № 112-Ф3 «О внесении изменений в Федеральный закон «Об основных гарантиях избирательных прав и права на участие в референдуме граждан Российской Федерации» в связи с изменением порядка досрочного голосования на выборах в органы местного самоуправления» // Рос. газ. 2010. 4 июня.

${ }^{4}$ См. Проект Федерального закона № 382589-5 «О внесении изменений в отдельные законодательные акты Российской Федерации в связи с уточнением порядка использования открепительных удостоверений при проведении выборов и референдумов».

${ }^{5}$ См. Проект Федерального закона № 357233-5 «О внесении изменений в отдельные законодательные акты Российской Федерации в связи с установлением дополнительных гарантий обеспечения равных условий предоставления помещений для встреч с избирателями, участниками референдума».

${ }^{6}$ См. Федеральный закон от 6 мая 2010 г. № 80-Ф3 «О внесении изменений в статью 32 Федерального закона «О политических партиях» // СЗ РФ. 2010. № 19. Ст. 2288. 
Президент подписывает федеральные законы о выборах (обладает правом вето в отношении принятых Федеральным Собранием Российской Федерации федеральных законов о выборах).

Президент принимает меры по обеспечению единства правового пространства Российской Федерации ${ }^{1}$.

Президент принимает решения в пределах компетенции о совершенствовании системы субъектов защиты конституционного строя в избирательном процессе (путем реформирования, создания или ликвидации соответствующих субъектов) и о содержании деятельности по защите конституционного строя в избирательном процессе.

Президент контролирует деятельность подведомственных государственных органов, осуществляющих защиту конституционного строя в избирательном процессе.

Президенту принадлежит право назначать и освобождать от должности высших должностных лиц федеральных органов исполнительной власти, непосредственно осуществляющих защиту конституционного строя.

В соответствии с пунктом «ж» статьи 83 Конституции России Президент Российской Федерации формирует и возглавляет Совет Безопасности Российской Федерации, статус которого определяется федеральным законом².

Совет Безопасности Российской Федерации является конституционным органом, осуществляющим подготовку решений Президента Российской Федерации по вопросам стратегии развития Российской Федерации, обеспечения безопасности жизненно важных интересов личности, общества и государства от внутренних и внешних угроз, проведения единой государственной политики в области обеспечения национальной безопасности ${ }^{3}$.

\footnotetext{
${ }^{1}$ См. Указ Президента Российской Федерации от 10 августа 2000 г. № 1486 «О дополнительных мерах по обеспечению единства правового пространства Российской Федерации» // СЗ РФ. 2000. № 33. Ст. 3356.

2 Федеральный закон о Совете Безопасности Российской Федерации до настоящего времени не принят.

${ }^{3}$ См.: Указ Президента Российской Федерации от 7 июня 2004 г. (в ред. от 21 октября 2008 г.) № 726 «Об утверждении Положений о Совете Безопасности Российской Федерации и аппарате Совета Безопасности Российской Федерации, а также об изменении и признании утратившими силу отдельных актов Президента Российской Федерации» // С3 РФ. 2004. № 24. Ст. 2392; 2008. № 43. Ст. 4919.
} 
Представляется, что основными задачами Совета Безопасности в избирательном процессе являются: обеспечение условий для реализации Президентом Российской Федерации его конституционных полномочий по защите прав и свобод человека и гражданина, охране суверенитета Российской Федерации, ее независимости и государственной целостности; разработка основных направлений стратегии развития государства и защиты конституционного строя в условиях выборов; подготовка предложений Президенту Российской Федерации для принятия главой государства решений по вопросам внутренней и внешней политики Российской Федерации в области защиты конституционного строя; подготовка решений по нейтрализации угроз конституционному строю, возникающих в избирательном процессе; подготовка предложений по координации деятельности федеральных органов исполнительной власти и органов исполнительной власти субъектов Российской Федерации в процессе реализации принятых решений в области защиты конституционного строя и оценка их эффективности; подготовка предложений Президенту Российской Федерации по реформированию существующих либо созданию новых субъектов защиты конституционного строя; решение иных задач в сфере защиты конституционного строя, возникающих в ходе избирательных кампаний.

На уровне субъектов Российской Федерации реализацию конституционных полномочий главы государства осуществляют полномочные представители Президента Российской Федерации в федеральных округах.

Среди субъектов общей компетенции следует также выделить Федеральное Собрание Российской Федерации, которое:

принимает федеральные конституционные и федеральные законы, регламентирующие отношения в сфере защиты конституционного строя России;

принимает федеральные законы о выборах;

принимает участие в формировании Центральной избирательной комиссии Российской Федерации (пять членов Центральной избирательной комиссии Российской Федерации назначаются Государственной Думой Федерального Собрания Российской Федерации из числа кандидатур, предложенных 
фракциями, иными депутатскими объединениями в Государственной Думе, а также депутатами Государственной Думы. Пять членов Центральной избирательной комиссии Российской Федерации назначаются Советом Федерации Федерального Собрания Российской Федерации из числа кандидатур, предложенных законодательными органами государственной власти субъектов Российской Федерации и высшими должностными лицами субъектов Российской Федерации $)^{1}$;

при наличии законных оснований может инициировать процедуру расформирования Центральной избирательной комиссии Российской Федерации и избирательной комиссии субъекта Российской Федерации (для начала процедуры расформирования комиссий требуется обращение в суд группы численностью не менее $1 / 3$ от общего числа членов Совета Федерации или депутатов Государственной Думы Федерального Собрания Российской Федерации $)^{2}$;

обладает правом законодательной инициативы в части реформирования избирательной системы;

определяет правовой статус субъектов защиты конституционного строя в избирательном процессе;

направляет парламентские запросы и проводит парламентские слушания в связи с нарушениями законодательства о выборах в Российской Федерации; проводит парламентские расследованияㄹ

совершенствует меры административного и уголовно-правового воздействия на правонарушителей в сфере выборов.

Собственными полномочиями по защите конституционного строя в избирательном процессе обладает каждая из палат Федерального Собрания Российской Федерации.

${ }^{1}$ Как уже отмечалось, остальные 5 членов ЦИК России назначаются Президентом Российской Федерации. Установленный порядок формирования ЦИК России направлен на обеспечение ее независимости как элемента государственно-правового статуса комиссии, поскольку ни один из государственных органов не обладает монопольным правом на назначение членов ЦИК России.

${ }^{2}$ См. Пункты 2 и 3 статьи 31 Федерального закона от 12 июня 2002 г. № 67-Ф3.

3 В целях невозможности использования инструмента парламентского расследования для действий, несовместимых с назначением этого института, Федеральный закон от 27 декабря 2005 г. № $196-\Phi 3$ «О парламентском расследовании Федерального Собрания Российской Федерации» определяет запрет на возбуждение расследования в течение последних 6 месяцев полномочий Президента Российской Федерации и Государственной Думы, а также в период проведения избирательных кампаний по выборам Президента Российской Федерации и выборам депутатов Государственной Думы Федерального Собрания Российской Федерации. 
В составе Государственной Думы и Совета Федерации функционируют комитеты и комиссии, осуществляющие деятельность по защите конституционного строя в избирательном процессе (например, разработку и совершенствование конституционного и избирательного законодательства, законодательное обеспечение противодействия коррупции, терроризму, рассмотрение расходов федерального бюджета, направленных на обеспечение защиты конституционного строя России) ${ }^{1}$. Каждая из палат Федерального Собрания, а также 1/5 членов Совета Федерации или депутатов Государственной Думы вправе обратиться в Конституционный Суд Российской Федерации с запросом о соответствии Конституции Российской Федерации федеральных законов, нормативных правовых актов Президента Российской Федерации, Совета Федерации, Государственной Думы, Правительства Российской Федерации, конституций республик, уставов, а также законов и иных нормативных правовых актов субъектов Российской Федерации, регулирующих общественные отношения в сфере выборов. Отдельные депутаты могут направить запрос в федеральные органы исполнительной власти, участвующие в защите конституционного строя, или обратиться с вопросом к представителям соответствующих государственных органов и учреждений.

В целях изучения практики организации и проведения выборов, предотвращения, выявления и устранения нарушений избирательного законодательства, оценки действий уполномоченных органов и организаций по обеспечению защиты конституционного строя в избирательном процессе Государственная Дума формирует специальные комиссии по изучению

${ }^{1}$ См. Постановление Государственной Думы Федерального Собрания Российской Федерации от 20 января 1999 г. N 3535-ІІ ГД «О заявлении Государственной Думы Федерального Собрания Российской Федерации «О совершенствовании законодательства Российской Федерации о выборах" // С3 РФ. 1999. № 5. Ст. 627; Постановление Совета Федерации Федерального Собрания Российской Федерации от 8 февраля 2006 г. № 36-СФ «О докладе Совета Федерации Федерального Собрания Российской Федерации 2005 года «О состоянии законодательства в Российской Федерации» // С3 РФ. 2006. № 7. Ст. 746; Постановление Совета Федерации Федерального Собрания Российской Федерации от 27 октября 2004 г. № 325-СФ «О Временной комиссии Совета Федерации Федерального Собрания Российской Федерации по подготовке законодательных предложений по противодействию терроризму» // С3 РФ. 2004. № 44. Ст. 4275. 
подготовки и проведения выборов и проверке соблюдения избирательного законодательства ${ }^{1}$.

Существенными полномочиями в рассматриваемой сфере наделен Совет Федерации. Верхняя палата Федерального Собрания Российской Федерации назначает выборы Президента Российской Федерации ${ }^{2}$ и отрешает его от должности; назначает на должность судей высших судебных инстанций Российской Федерации, а также Генерального прокурора Российской Федерации. Совет Федерации готовит и рассматривает законодательные предложения, направленные на реформирование системы защиты конституционного строя, рассматривает принятые Государственной Думой федеральные законы по вопросам ратификации и денонсации международных договоров (в том числе, устанавливающих международные избирательные стандарты).

Правительство Российской Федерации как субъект общей компетенции: осуществляет руководство подведомственными государственными органами, участвующими в защите конституционного строя в избирательном процессе;

координирует деятельность федеральных органов исполнительной власти, а также органов исполнительной власти субъектов Российской Федерации;

обладает правом законодательной инициативы, а также дает заключение на законопроекты в сфере выборов и защиты конституционного строя, требующие расходов федерального бюджета;

разрабатывает федеральный бюджет;

\footnotetext{
${ }^{1}$ См. Постановление Государственной Думы Федерального Собрания Российской Федерации от 16 апреля 1998 г. N 2394-II ГД «О создании Комиссии Государственной Думы Федерального Собрания Российской Федерации по проверке соблюдения избирательного законодательства в ходе подготовки и проведения выборов мэра города Нижнего Новгорода»// СЗ РФ. 1998. № 17. Ст. 1897; Постановление Государственной Думы Федерального Собрания Российской Федерации от 23 октября 2002 г. № 33170-III ГД «О комиссии Государственной Думы Федерального Собрания Российской Федерации по изучению подготовки и проведения выборов депутатов Законодательного Собрания города Санкт-Петербурга» // С3 РФ. 2002. № 44. Ст. 4334. О деятельности парламентских комиссий по проверке соблюдения избирательного законодательства см. Дмитриев Ю.А., Исраелян В.Б. Избирательное право и процесс в Российской Федерации. Ростов-на-Дону, 2004. С. 702.

${ }^{2}$ См. Постановление Совета Федерации Федерального Собрания Российской Федерации от 10 декабря 2003 г. № 337-СФ «О назначении выборов Президента Российской Федерации» // С3 РФ. 2003. № 51. Ст. 4945; Постановление Совета Федерации Федерального Собрания Российской Федерации от 26 ноября 2007 г. № 550-СФ «О назначении выборов Президента Российской Федерации» // СЗ РФ. 2007. № 49. Ст. 6130.
} 
издает нормативные правовые акты, регламентирующие вопросы оказания содействия избирательным комиссиям в организации и проведении выборов в Российской Федерации ${ }^{1}$;

вправе обратиться в Конституционный Суд Российской Федерации с запросом о соответствии Конституции Российской Федерации федеральных законов, нормативных правовых актов Президента Российской Федерации, Совета Федерации, Государственной Думы, Правительства Российской Федерации, конституций республик, уставов, а также законов и иных нормативных правовых актов субъектов Российской Федерации, регулирующих общественные отношения в сфере выборов;

организует разработку и реализацию государственных программ защиты конституционного строя;

осуществляет финансовое обеспечение выборов в органы государственной власти Российской Федерации;

финансирует федеральные целевые программы развития избирательной системы Российской Федерации ${ }^{2}$;

обеспечивает социальные гарантии для военнослужащих и иных лиц, привлекаемых к защите конституционного строя;

обеспечивает исполнение нормативных правовых актов, регламентирующих отношения в сфере выборов и защиты конституционного строя;

контролирует деятельность подведомственных государственных органов, обеспечивающих защиту конституционного строя в избирательном процессе.

В системе субъектов общей компетенции заметную роль играют органы государственной власти субъектов Российской Федерации.

\section{Органы государственной власти субъектов Российской Федерации} (законодательные органы государственной власти и высшие должностные лица субъектов Российской Федерации) предлагают кандидатуры для назначения членов Центральной избирательной комиссии Российской Федерации от Совета

${ }^{1}$ См., например, Постановления Правительства Российской Федерации от 25 августа 1999 г. № 937, от 13 января 2000 г. № 32, от 5 сентября 2003 г. № 555, от 17 сентября 2007 года № 589.

2 Правительство Российской Федерации осуществляло финансирование расходов, связанных с осуществлением федеральных целевых программ, обеспечивающих выборы (например, создания Государственной автоматизированной системы Российской Федерации «Выборы» и реализации Федеральной целевой программы повышения правовой культуры избирателей и организаторов выборов в Российской Федерации). 
Федерации Федерального Собрания Российской Федерации, формируют избирательную комиссию субъекта Российской Федерации на основе предложений политических партий, представленных в Государственной Думе Федерального Собрания Российской Федерации, законодательном органе государственной власти субъекта Российской Федерации, предложений представительных органов муниципальных образований, избирательной комиссии субъекта Российской Федерации предыдущего состава, ЦИК России.

Органы законодательной и исполнительной власти субъекта Российской Федерации вправе обратиться в Конституционный Суд Российской Федерации с запросом о соответствии Конституции Российской Федерации федеральных законов, нормативных правовых актов Президента Российской Федерации, Совета Федерации, Государственной Думы, Правительства Российской Федерации, конституций республик, уставов, а также законов и иных нормативных правовых актов субъектов Российской Федерации, регулирующих общественные отношения в сфере выборов.

Органы законодательной власти субъектов Российской Федерации обладают правом законодательной инициативы в части реформирования избирательной системы, принимают участие в организации Государственной системы регистрации (учета) избирателей, участников референдума и осуществлении регистрации (учета) избирателей.

Депутаты законодательного органа государственной власти субъекта Российской Федерации численностью не менее $1 / 3$ от общего числа депутатов либо группа депутатов любой из избираемых палат численностью не менее 1/3 от общего числа депутатов этой палаты вправе обратиться в суд о расформировании избирательной комиссии субъекта Российской Федерации, окружной избирательной комиссии по выборам в законодательный орган государственной власти субъекта Российской Федерации, избирательной комиссии муниципального образования, окружной избирательной комиссии по выборам в представительный орган муниципального образования, территориальной, участковой комиссии. 
Органы государственной власти субъектов Российской Федерации осуществляют необходимые меры по материальному и социальному обеспечению (в том числе по медицинскому, санаторно-курортному, жилищно-бытовому, пенсионному и иным видам обеспечения) работников аппаратов избирательных комиссий.

В соответствии с Конституцией Российской Федерации часть задач по защите конституционного строя находится в совместном ведении Российской Федерации и ее субъектов. К их числу относятся: обеспечение соответствия конституций, уставов и законов субъектов Российской Федерации Конституции Российской Федерации и федеральным законам; защита прав и свобод человека и гражданина; защита прав национальных меньшинств; обеспечение законности, правопорядка, общественной безопасности; режим пограничных зон. На основании данного конституционного положения органы государственной власти субъектов Российской Федерации участвуют в осуществлении целевых программ по борьбе с преступностью, разработке комплексных мер профилактики терроризма и экстремизма, повышения правовой культуры избирателей и организаторов выборов, принимают соответствующие нормативные правовые акты, не противоречащие Конституции Российской Федерации и федеральным законам, взаимодействуют с уполномоченными территориальными органами федеральных органов исполнительной власти, обеспечивают в пределах своих полномочий и территорий реализацию мер социальной и правовой защиты военного и гражданского персонала государственных органов и учреждений, связанных с защитой конституционного строя ${ }^{1}$. При высших должностных лицах субъектов Российской Федерации функционируют Советы безопасности и антитеррористические комиссии субъектов Российской Федерации.

\footnotetext{
1 См. Республиканская целевая программа «О профилактике терроризма и экстремизма в КабардиноБалкарской Республике на 2008-2010 годы», целевая программа Приморского края «Комплексные меры по борьбе с преступностью и терроризмом на 2005-2009 годы», «Целевая программа профилактики терроризма и экстремизма в Новгородской области на 2009-2010 годы», «Областная целевая программа «Профилактика терроризма и экстремизма» на территории Оренбургской области на 2008-2010 годы», Программа по борьбе с преступностью в Оренбургской области на 2007-2009 годы, Областная целевая программа «Усиление борьбы с преступностью в Саратовской области» на 2008-2010 годы, Областная целевая программа профилактики терроризма и экстремизма в Саратовской области на 2008-2010 годы и др.
} 
Рассмотрев систему субъектов общей компетенции, обеспечивающих защиту конституционного строя в избирательном процессе, акцентируем внимание на изучении субъектов специальной компетенции, поскольку именно они выполняют основной объем работы по защите конституционного строя в условиях выборов всех уровней, а также осуществляют необходимые организационно-технические мероприятия, связанные с подготовкой и проведением избирательных кампаний ${ }^{1}$.

В соответствии с законодательством Российской Федерации субъекты специальной компетенции в условиях выборов призваны решать следующие основные задачи:

1. Противодействие возможным попыткам российских организованных преступных групп, террористических и иных экстремистских организаций и отдельных лиц, а также представителей спецслужб и организаций иностранных государств продвижения своих кандидатов в органы государственной власти и местного самоуправления Российской Федерации в условиях выборов²

2. Выявление, предупреждение и пресечение призывов к насильственному изменению конституционного строя, нарушению целостности России, к совершению массовых беспорядков, действиям, возбуждающим социальную, расовую, национальную, религиозную вражду, унижающим национальное достоинство, пропагандирующим исключительность, превосходство либо неполноценность граждан по признаку их отношения к религии, социальной, расовой, национальной, религиозной или языковой принадлежности; агитации, при проведении которой осуществляются пропаганда и публичное демонстрирование нацистской либо схожей атрибутики или символики; избирательных технологий манипулятивного воздействия на общественное сознание ${ }^{3}$;

1 Задачи, полномочия и формы участия конкретных субъектов специальной компетенции в защите конституционного строя в избирательном процессе рассмотрены в параграфе 2.3 .

2 П.6 ст.3, п.9 ст. 37 , п. «е» ст.48, п.4. ст.61, п.7 ст.63, пп. «Г» п.5 ст.76 Федерального закона от 12 июня 2002 г. № 67-ФЗ // Рос. газ. 2002. 15 июня; 2002. 28 сентября; 2003. 25 июня; 2003. 8 июля; 2004. 9 июня; 2004. 14 августа; 2004. 31 августа; 2004. 15 декабря; 2005. 2 июля; 2005. 26 июля; 2006. 15 июля; 2006. 27 июля; 2006. 7 декабря; 2007. 10 января; 2007. 2 февраля; 2007. 6 марта; 2007. 24 апреля; 2007. 11 мая; 2007. 1 августа; 2008. 25 июля; 2008. 28 ноября; 2008. 31 декабря; 2009. 11 февраля; 2009. 8 апреля; 10 июня; 2010. 26 апреля.

${ }^{3}$ См. ст.3 и ч.3 ст.10 Федерального закона «О противодействии экстремистской деятельности» // СЗ РФ. 2002. № 30. Ст. 3031. 
3. Выявление, предупреждение и пресечение финансовых злоупотреблений при формировании и использовании средств избирательных фондов; противоправных действий по подкупу избирателей; фактов зарубежного финансирования избирательных кампаний отдельных кандидатов и избирательных объединений, направленных на изменение и подрыв конституционного строя России ;

4. Содействие избирательным комиссиям в установленных законодательством формах (контроль за целевым расходованием денежных средств, выделенных комиссиям на проведение выборов; контроль за возвратом бюджетных средств, выделенных в избирательные фонды зарегистрированных кандидатов или политических партий, зарегистрировавших списки кандидатов; контроль за источниками поступления, правильным учетом и использованием денежных средств избирательных фондов; проверка финансовых отчетов кандидатов и политических партий; проверка достоверности представленных кандидатами сведений; проверка достоверности сведений об избирателях и их подписей в подписных листах; исполнение представлений избирательных комиссий $)^{2}$;

5. Обеспечение безопасности общественно-политических и иных массовых агитационных мероприятий ${ }^{3}$;

6. Обеспечение безопасности членов избирательных комиссий, контрольно-ревизионных служб, судей, а также их близких, если им оказывается сопротивление или угрожает опасность, а также оказание содействия кандидатам, зарегистрированным кандидатам в депутаты или на выборные должности в органах государственной власти и органах местного самоуправления, членам

${ }^{1}$ См. П. 28 ст. 10 Закона Российской Федерации «О милиции» // Ведомости СНД и ВС РСФСР. 1991. № 16. Ст. 503; Ведомости СНД и ВС РСФСР. 1993. № 10. Ст. 360; Ведомости СНД и ВС РСФСР. 1993. № 32. Ст. 1231; СЗ РФ. 1996. № 25. Ст. 2964; 1999. № 14. Ст. 1666; 1999. № 49. Ст. 5905; 2000. № 31. Ст. 3204; 2000 . № 46. Ст. 4537; 2001. № 31. Ст. 3172; 2001. № 32. Ст. 3316; 2002. № 18. Ст. 1721; 2002. № 27. Ст. 2620; 2002. № 30. Ст. 3029; 2003. № 2. Ст. 167; 2003. № 27 (ч. 1). Ст. 2700; 2003. № 28. Ст. 2880; 2003. № 50. Ст. 4847; 2004. № 30. Ст. 3087; 2004. № 35. Ст. 3607; 2005. № 13. Ст. 1078; 2005. № 14. Ст. 1212; 2005. № 19. Ст. 1752; 2006. № 24. Ст. $2555 ; 2006$. № 31 (ч. 1). Ст. 3420; 2006. № 31 (ч. 1). Ст. 3425; 2006. № 52 (ч. 1). Ст. 5498; 2007. № 10. Ст. 1151; 2007. № 41. Ст. 4845; 2008. № 30 (ч. 2). Ст. 3616; 2008. № 52 (ч. 1). Ст. 6235; 2008. № 52 (ч. 1). Ст. 6248; 2010. № 1. Ст. 4.

${ }^{2}$ См. П.1 ст. 60 Федерального закона от 12 июня 2002 г. № 67-Ф3, ч.1 ст. 71 Федерального закона от 18 мая 2005 г. № 51-Ф3, п. 27 ст. 10 Закона Российской Федерации «О милиции».

${ }^{3}$ См. П. 8 ст. 53 Федерального закона от 12 июня 2002 г. № 67-Ф3. 
избирательных комиссий, представителям общественных объединений в осуществлении их законной деятельности ${ }^{1}$;

7. Обеспечение информационной безопасности Государственной автоматизированной системы Российской Федерации (ГАС) «Выборы»².

2.3. Нормативное правовое регулирование участия компетентных государственных органов и учреждений в защите конституционного строя России в избирательном процессе

Учитывая объем, характер, специфику полномочий и затратность решаемых задач, защита конституционного строя в условиях избирательного процесса, как правило, является результатом совместной деятельности всех субъектов специальной компетенции: избирательных комиссий, органов федеральной службы безопасности, органов внутренних дел, органов Федеральной миграционной службы, прокуратуры, судов, налоговых органов, органов юстиции, органов Министерства иностранных дел, органов Министерства по делам гражданской обороны, чрезвычайным ситуациям и ликвидации последствий стихийных бедствий, воинских формирований и органов Министерства обороны Российской Федерации.

Особое значение в предвыборный период имеет нормативное правовое регулирование деятельности компетентных государственных органов, связанной с регистрацией (учетом) избирателей ${ }^{3}$.

Федеральные органы исполнительной власти, органы исполнительной власти субъектов Российской Федерации должны оказывать необходимое содействие органам местного самоуправления и избирательным комиссиям при регистрации (учете) избирателей и уточнении сведений о зарегистрированных избирателя ${ }^{4}$. В соответствии с пунктом 3 Постановления Правительства

\footnotetext{
${ }^{1}$ См. П. 23 и 24 ст. 10 Закона Российской Федерации «О милиции».

${ }^{2}$ См. Ст. 11.2 Федерального закона «О федеральной службе безопасности» // Рос. газ. 1995. 12 апреля; 2000. 6 января; 2002. 30 июля; 2003. 14 января; 2003. 1 июля; 2004. 31 августа; 2005. 11 марта; 2006. 21 апреля; 2006.29 июля; 2007. 1 августа; 2007. 8 декабря; 2008. 30 декабря; ст.ст. 21-24 Федерального закона «О Государственной автоматизированной системе Российской Федерации «Выборы» // Рос. газ. 2003. 15 января; 2008. 30 декабря.

${ }^{3}$ См.: Ефименко Е.А. Регистрация избирателей, участников референдума в Российской Федерации: правовой режим, особенности, недостатки // Конституционное и муниципальное право. 2007. № 3. С. 27-31.

4 Подробней см.: Cmепашин C.B. Взаимодействие органов исполнительной власти с избирательными комиссиями в процессе подготовки и проведения предстоящих федеральных выборов // Вестник ЦИК России. 1999. № 6. C. 19-22.
} 
Российской Федерации от 17 сентября 2007 г. № 589 органы министерства обороны, министерства внутренних дел, министерства по делам гражданской обороны, чрезвычайным ситуациям и ликвидации последствий стихийных бедствий, министерства иностранных дел, федеральной службы исполнения наказаний, федеральной службы безопасности и ряда других государственных органов в пределах установленной компетенции обеспечивают представление сведений для составления и уточнения списков избирателей ${ }^{1}$.

На основании пункта 22 Постановления Правительства Российской Федерации от 17 сентября 2007 г. № 589 Федеральная миграционная служба должна направлять уведомления о регистрации граждан по новому месту жительства в орган регистрационного учета по прежнему месту жительства для снятия граждан с регистрационного учета. В целях уточнения списков избирателей органы исполнительной власти субъектов Российской Федерации и органы местного самоуправления представляют в избирательные комиссии сведения о фактах смерти граждан Российской Федерации.

Пункт 4 указанного Постановления Правительства Российской Федерации предписывает перечисленным выше органам исполнительной власти в порядке и сроки, установленные статьей 13 Федерального закона от 18 мая 2005 г. № 51-Ф3 и статьей 25 Федерального закона от 10 января 2003 г. № 19-Ф3 обеспечивать содействие образованию избирательных участков. В пункте 6 Постановления Правительства Российской Федерации от 17 сентября 2007 г. № 589 на компетентные государственные органы (органы министерства обороны, министерства внутренних дел, министерства по делам гражданской обороны, чрезвычайным ситуациям и ликвидации последствий стихийных бедствий, министерства иностранных дел, федеральной службы исполнения наказаний, федеральной службы безопасности) возлагается обязанность обеспечить избирательные права граждан, проходящих службу в соответствующих органах и воинских частях, а также проживающих на территории расположения воинских частей ${ }^{2}$.

\footnotetext{
${ }^{1}$ См.: Рос. газ. 2007. 26 сентября.

${ }^{2}$ См.: Никитин А.П. Вопросы взаимодействия органов военного управления с избирательными комиссиями в процессе обеспечения активных избирательных прав военнослужащих // Право в Вооруженных Силах. 2007 . № 8. C. $32-35$.
} 
На стадии формирования избирательных комиссий органы федеральной службы безопасности совместно с органами внутренних дел и МИД России проверяют наличие в составе комиссий лиц, имеющих гражданство иностранного государства, либо вид на жительство или иной документ, подтверждающий право на постоянное проживание гражданина Российской Федерации на территории иностранного государства; имеющих неснятую и непогашенную судимость; утративших свои полномочия в результате расформирования комиссий, а также лиц, подвергнутых в судебном порядке наказанию за нарушения законодательства о выборах. В случае назначения указанных лиц в состав избирательной комиссии компетентные государственные органы информируют председателя соответствующей комиссии о необходимости прекращения полномочий данных членов комиссии.

Формирование участковых избирательных комиссий за пределами территории Российской Федерации обеспечивают согласно части 5 статьи 21 Федерального закона от 18 мая 2005 г. № 51-Ф3 и пункту 5 статьи 15 Федерального закона от 10 января 2003 г. № 19-Ф3 Министерство обороны и Министерство иностранных дел Российской Федерации.

Необходимость проверки сведений о кандидатах (списков кандидатов) на стадии их выдвижения и регистрации обусловливает участие компетентных государственных органов и учреждений в деятельности контрольно-ревизионных служб при избирательных комиссиях ${ }^{1}$. Пункт 20 Постановления Правительства Российской Федерации от 17 сентября 2007 г. № 589 предписывает Министерству внутренних дел, Министерству юстиции, Министерству по делам гражданской обороны, чрезвычайным ситуациям и ликвидации последствий стихийных бедствий, Федеральной службе безопасности и иным государственным органам откомандировывать специалистов по запросам соответствующих избирательных комиссий для работы в контрольно-ревизионных службах при

\footnotetext{
${ }^{1}$ См.: Степашин С.В. Взаимодействие органов исполнительной власти с избирательными комиссиями в процессе подготовки и проведения предстоящих федеральных выборов // Вестник ЦИК России. 1999. № 6. С. 1922; Абанин О.А., Рейдель Л.Б. Взаимодействие избирательных комиссий с органами государственной власти и органами местного самоуправления // Правовая политика и правовая жизнь. 2008. № 4. С. 46-52.
} 
Центральной избирательной комиссии Российской Федерации и избирательных комиссиях субъектов Российской Федерации. Там же содержится рекомендация Центральному банку Российской Федерации, главным управлениям (национальным банкам) Центрального банка Российской Федерации в субъектах Российской Федерации, Сберегательному банку Российской Федерации откомандировывать по запросам Центральной избирательной комиссии Российской Федерации и избирательных комиссий субъектов Российской Федерации специалистов для работы в составе контрольно-ревизионных служб при соответствующих комиссиях.

В ходе избирательной кампании по проведению выборов Президента Российской Федерации 2008 г. в состав Контрольно-ревизионной службы при ЦИК России вошли члены Комиссии с правом решающего голоса (6 человек), работники Аппарата Комиссии (7 человек), а также руководители и специалисты МВД России (9 человек), ФНС России (2 человека), Минфина России (4 человека), Банка России (1 человек), Сбербанка России (1 человек), ФСБ России (2 человека), ФМС России (1 человек), Минюста России (2 человека), иных органов и организаций (11 человек) $)^{1}$. Количество членов контрольно-ревизионных служб при избирательных комиссиях субъектов Российской Федерации колеблется от 7 (Агинский Бурятский и Ненецкий автономные округа) до 30 человек (Смоленская и Ярославская области). Для выполнения возложенных на контрольно-ревизионные службы задач создаются рабочие группы.

Пункт 21 Постановления Правительства Российской Федерации от 17 сентября 2007 г. № 589 определяет требование Министерству внутренних дел, Министерству обороны, Министерству юстиции, Федеральной миграционной службе по запросам Центральной избирательной комиссии Российской Федерации и избирательных комиссий субъектов Российской Федерации направлять специалистов для участия в проверке соблюдения порядка сбора подписей избирателей и оформления подписных листов, достоверности содержащихся в подписных листах сведений об избирателях и их подписей,

\footnotetext{
1 См. Выборы Президента Российской Федерации. 2008: Сборник информационно-аналитических материалов /Центральная избирательная комиссия Российской Федерации. М.: СитиПрессСервис, 2008. С. 109.
} 
поставленных в поддержку выдвижения федеральных списков кандидатов и кандидатов на должность Президента Российской Федерации.

Наряду с проверкой достоверности представленных кандидатами сведений о размере и об источниках доходов, имуществе и обязательствах имущественного характера контрольно-ревизионные службы осуществляют контроль за целевым расходованием денежных средств, выделенных комиссиям на организацию и проведение выборов, а также за источниками поступления, правильным учетом и использованием денежных средств избирательных фондов, проверяют финансовые отчеты кандидатов, избирательных объединений, контролируют возврат бюджетных средств ${ }^{1}$.

По представлениям Центральной избирательной комиссии Российской Федерации, согласно пункту 5 статьи 20 Федерального закона от 12 июня 2002 г. № 67-Ф3, правоохранительными органами совместно с другими органами исполнительной власти проводится проверка достоверности сведений о наличии у кандидатов в депутаты неснятой или непогашенной судимости, гражданстве иностранного государства, а также об их доходах и имуществе, проверяется достоверность сведений об организациях и лицах, внесших пожертвования в избирательные фонды политических партий и избирательных объединений ${ }^{2}$. Данное законодательное положение детализируется в пунктах 7, 9, 24 и 25 Постановления Правительства Российской Федерации от 17 сентября 2007 г. № 589.

В интересах защиты конституционного строя детальной правовой регламентации подвержена деятельность компетентных государственных органов на стадии информирования избирателей и предвыборной агитации. Предписания статьи 62 Федерального закона от 18 мая 2005 г. № 51-Ф3, статьи 56 Федерального закона от 10 января 2003 г. № 19-Ф3 содержат обязанность правоохранительных органов пресекать противоправную агитационную деятельность, а пункт 13 Постановления Правительства Российской Федерации от 17 сентября 2007 г. № 589 конкретизирует эту обязанность применительно к

\footnotetext{
${ }^{1}$ См.: Абанин О.А., Рейдель Л.Б. Взаимодействие избирательных комиссий с органами государственной власти и органами местного самоуправления // Правовая политика и правовая жизнь. 2008. № 4. С. 46-52.

2 Частью 1 статьи 8 Закона Российской Федерации «О прокуратуре Российской Федерации» установлено, что в систему правоохранительных органов входят органы прокуратуры, органы внутренних дел, органы федеральной службы безопасности, органы таможенной службы и другие правоохранительные органы.
} 
Министерству внутренних дел, Федеральной регистрационной службе, Федеральной службе по надзору в сфере массовых коммуникаций, связи и охраны культурного наследия, а также Федеральной службе безопасности. Названные государственные органы должны принимать незамедлительные меры по пресечению экстремистской агитации.

Об актуальности противодействия экстремизму в связи с проведением федеральных избирательных кампаний по выборам депутатов Государственной Думы Федерального Собрания Российской Федерации 2007 г. и выборам Президента Российской Федерации 2008 г. свидетельствует внимание Президента Российской Федерации к этой проблеме. Выступая 31 января 2007 г. на Коллегии ФСБ России, Президент Российской Федерации отметил: «Важно не только обеспечить законность и правопорядок, но и обезопасить общество от попыток вброса в общественно-политическое поле идеологии экстремизма, национальной и конфессиональной нетерпимости» ${ }^{1}$. Глава государства подчеркнул, что эта работа должна вестись в соответствии с положениями Конституции. Между тем, практика выборов депутатов Государственной Думы Федерального Собрания Российской Федерации пятого созыва указывает на неоднократные примеры незаконного изъятия правоохранительными органами агитационных материалов 2.

Анализ полномочий субъектов защиты конституционного строя в избирательном процессе позволяет выявить несколько дублирующих функций компетентных государственных органов. Так, пресечением противоправной агитационной деятельности занимаются МВД, ФРС, Федеральная служба по надзору в сфере массовых коммуникаций, связи и охраны культурного наследия, а также ФСБ. Мониторинг содержания печатной, аудио- и аудиовизуальной продукции СМИ, изготавливаемой и (или) распространяемой на территории России с целью определения ее соответствия требованиям законодательства о выборах осуществляют избирательные комиссии, органы Федеральной службы по надзору в сфере массовых коммуникаций, связи и охраны культурного наследия, а также органы прокуратуры. Нечеткость нормативного разграничения

\footnotetext{
${ }^{1}$ CM.: http://archive.kremlin.ru/2007/01/31/news

2 См. Решение Верховного Суда Российской Федерации от 3 июля 2008 г. по делу № ГКПИ08-1472 по заявлению политической партии «Союз правых сил», Белых Н.Ю., Прохорова В.Ю и Казакова С.П. о признании результатов выборов депутатов Государственной Думы Федерального Собрания Российской Федерации пятого созыва, состоявшихся 2 декабря 2007 г., недействительными.
} 
компетенции субъектов защиты конституционного строя в избирательном процессе затрудняет использование имеющихся сил и средств и снижает эффективность функционирования конституционно-правового механизма защиты конституционного строя в избирательном процессе.

Пункт 8 статьи 53 Федерального закона от 12 июня 2002 г. № 67-Ф3 закрепляет участие компетентных государственных органов в пределах своих полномочий в обеспечении безопасности проводимых в ходе предвыборной агитации общественно-политических и иных публичных мероприятий. Согласно пункту 5 части 1 статьи 12 Федерального закона от 9 июня 2004 г. № 54-Ф3 «О собраниях, митингах, демонстрациях, шествиях и пикетированиях» общественный порядок и безопасность граждан при проведении публичного мероприятия обеспечивается органами исполнительной власти или органами местного самоуправления совместно с организаторами мероприятия и органами внутренних дел ${ }^{1}$. Организаторы агитационных публичных мероприятий несут ответственность за соблюдение установленных законодательством Российской Федерации требований, касающихся порядка проведения массовых акций, недопущения осуществления экстремистской деятельности, a также ее своевременного пресечения. Об указанной ответственности организаторы массовой акции до ее проведения предупреждаются в письменной форме органами внутренних дел ${ }^{2}$. В соответствии с Федеральным законом «О собраниях, митингах, демонстрациях, шествиях и пикетированиях» запрещается проведение массовых мероприятий на территориях, непосредственно прилегающих к опасным производственным объектам и объектам, эксплуатация которых требует соблюдения специальных правил техники безопасности; на путепроводах, железнодорожных магистралях, полосах отвода железных дорог, нефте- и газопроводах, высоковольтных линиях электропередач; на территориях, непосредственно прилегающих к резиденциям Президента Российской Федерации, к зданиям, занимаемым судами, к территориям и зданиям учреждений, исполняющих наказание в виде лишения свободы; в пограничной зоне.

\footnotetext{
1 См. СЗ РФ. 2004. № 25. Ст. 2485.

${ }^{2}$ См. ч. 1 ст. 16 Федерального закона от 25 июля 2002 г. № 114-Ф3 «О противодействии экстремистской деятельности» // СЗ РФ. 2002. № 30. СТ. 3031.
} 
В случае нарушения зарегистрированным кандидатом, политической партией правил проведения предвыборной агитации со злоупотреблением свободой массовой информации (агитация, содержащая призывы к насильственному изменению конституционного строя, нарушению целостности Российской Федерации, к совершению массовых беспорядков, к действиям, нарушающим равноправие граждан или возбуждающим социальную, расовую, национальную, религиозную вражду) избирательная комиссия обязана обратиться в суд с представлением об отмене регистрации кандидата (списка кандидатов) $)^{1}$. О фактах экстремистских призывов, а также о готовящихся террористических актах избирательные комиссии незамедлительно информируют органы федеральной службы безопасности и органы прокуратуры для принятия мер предупреждения, осуществления проверки сигналов, возбуждения уголовных дел при наличии достаточных оснований и производства расследования ${ }^{2}$.

На стадии голосования компетентные государственные органы (МВД и МЧС) проводят проверки безопасности и антитеррористической защищенности помещений избирательных комиссий и помещений для голосования.

В ходе организации голосования на избирательных участках, образованных за пределами территории Российской Федерации, избирательные комиссии взаимодействуют с Министерством иностранных дел, Министерством обороны и ФСБ России. Так, на выборах Президента Российской Федерации 2008 г. за пределами территории Российской Федерации в 142 странах было образовано 364 избирательных участка. Из них 42 участка было образовано по линии Министерства обороны Российской Федерации в 9 странах (Азербайджан, Армения, Беларусь, Грузия, Казахстан, Киргизия, Молдавия, Таджикистан, Украина) и 4 участка - по линии Пограничной службы ФСБ России (Армения)ㅇ․

\footnotetext{
${ }^{1}$ См. п.5 ст.20, пп. «д》 п.7, пп. «Д» п.8 ст.76 Федерального закона от 12 июня 2002 г. № 67-ФЗ. См. также Сидякин А.Г. Отказ в регистрации и отмена регистрации кандидата (списка кандидатов): проблемы теории и практики. Дис. ... канд. юрид. наук. М., 2006. 245 с.; Дмитриев Д.О. Отказ в регистрации и отмена регистрации основные меры конституционно-правовой ответственности кандидатов // Юстиция. 2006. № 6. С. 51-59.

${ }^{2}$ См. Приказ Генеральной прокуратуры Российской Федерации от 28 ноября 2007 г. № 190 «Об организации прокурорского надзора за исполнением законодательства о противодействии экстремистской деятельности».

3 См. Выборы Президента Российской Федерации. 2008: Сборник информационно-аналитических материалов /Центральная избирательная комиссия Российской Федерации. М.: СитиПрессСервис, 2008. С. 128.
} 
В соответствии с Постановлением Центральной избирательной комиссии Российской Федерации от 21 августа 2007 г. № 26/197-5 «О Методическом письме по вопросам организации голосования на избирательных участках, образованных за пределами территории Российской Федерации на выборах депутатов Государственной Думы Федерального Собрания Российской Федерации пятого созыва», Постановлением Центральной избирательной комиссии Российской Федерации от 28 декабря 2007 г. № 83/657-5 «О Методическом письме по вопросам организации голосования на выборах Президента Российской Федерации на избирательных участках, образованных за пределами территории Российской Федерации» Министерство иностранных дел Российской Федерации обеспечивает доставку информационных материалов, избирательных бюллетеней и марок для них. По согласованию с Министерством иностранных дел Российской Федерации допускается доставка избирательных бюллетеней и марок для избирательных бюллетеней Министерством обороны Российской Федерации и ФСБ России ${ }^{1}$.

Большой вклад в защиту конституционного строя в избирательном процессе вносит деятельность судебных органов.

В период выборов суды осуществляют контроль за строгим соблюдением демократических избирательных процедур, обеспечивающих свободу голосования. Пункт 3 статьи 77 Федерального закона от 12 июня 2002 г. № 67-Ф3 устанавливает, что суд соответствующего уровня может отменить решение избирательной комиссии об итогах голосования, о результатах выборов на избирательном участке, территории, в избирательном округе, муниципальном образовании, в субъекте Российской Федерации, в Российской Федерации в целом в случае нарушения правил составления списков избирателей, порядка формирования избирательных комиссий, порядка голосования и подсчета голосов (включая воспрепятствование наблюдению за их проведением), определения результатов выборов, незаконного отказа в регистрации кандидата, списка кандидатов, признанного таковым после дня голосования, других нарушений

\footnotetext{
${ }^{1}$ См. Вестник ЦИК Российской Федерации. 2007. № 12; 2008. № 4.
} 
избирательного законодательства, если эти нарушения не позволяют выявить действительную волю избирателей ${ }^{1}$.

Отменив решение избирательной комиссии об итогах голосования, о результатах выборов, суд может принять решение о проведении повторного подсчета голосов избирателей.

В случае нарушения избирательной комиссией избирательных прав граждан, повлекших признание недействительными итогов голосования на соответствующей территории либо результатов выборов; неисполнения комиссией решения суда или вышестоящей комиссии, решений Центральной избирательной комиссии Российской Федерации, избирательной комиссии субъекта Российской Федерации, избирательной комиссии муниципального района; невыполнения комиссией обязанности по назначению выборов, повлекшего за собой назначение выборов временной избирательной комиссией, избирательная комиссия может быть расформирована судом в соответствии со статьей 31 настоящего Федерального закона². Возможность расформирования избирательной комиссии повышает ее ответственность за допущенные нарушения избирательных прав и ненадлежащее осуществление своих функциональных обязанностей.

Суд может отменить решение избирательной комиссии о регистрации кандидата (списка кандидатов), об отказе в регистрации кандидата (списка кандидатов), если будет установлено, что решение было принято избирательной комиссией с нарушением требований, предусмотренных пунктами 24-26 статьи 38 Федерального закона от 12 июня 2002 г. № 67-Ф3, требований, предусмотренных иным законом.

${ }^{1}$ См. Определение Судебной коллегии по гражданским делам Верховного Суда Российской Федерации от 16 марта 2005 г. по делу № 83-ГО5-1.

2 Постановление Центральной избирательной комиссии Российской Федерации от 25 декабря 2002 г. № 167/1422-3 «О заявлении Центральной избирательной комиссии Российской Федерации в Красноярский краевой суд о расформировании Избирательной комиссии Красноярского края»; Определение судебной коллегии по гражданским делам Верховного Суда Российской Федерации от 4 апреля 2003 г. по делу № 53-ГО3-8; Постановление Центральной избирательной комиссии Российской Федерации от 25 января 2006 г. № 168/1095-4 «О заявлении Центральной избирательной комиссии Российской Федерации в Климовский городской суд Московской области о расформировании избирательной комиссии муниципального образования «Город Климовск Московской области»; Определение Московского областного суда от 28 февраля 2006 г. по делу № 33-2481. 
При проведении дополнительных выборов депутата Архангельского областного Собрания депутатов четвертого созыва 2006 г. окружная избирательная комиссия одномандатного избирательного округа № 3 г. Архангельска отказала гражданину Тутову А.Н. в регистрации кандидатом на дополнительных выборах депутата Архангельского областного Собрания депутатов четвертого созыва в связи с сокрытием им сведений о неснятой и непогашенной судимости. Тутов А.Н. обратился в Архангельский областной суд с жалобой на нарушение избирательных прав. Архангельский областной суд постановил, что, приняв решение баллотироваться в органы государственной власти, Тутов А.Н. был обязан добросовестно пользоваться своим конституционным правом и указать в заявлении и подписных листах наличие у него неснятой и непогашенной судимости. Суд подчеркнул, что требования федерального и областного законодательства о сообщении сведений о неснятой и непогашенной судимости направлены на более полное информирование избирателей о личности кандидата и, следовательно, на обеспечение конституционных прав граждан по осознанному волеизъявлению при выборе кандидата в органы государственной власти. В удовлетворении заявления Тутова А.Н. было отказано. Судебная коллегия по гражданским делам Верховного Суда Российской Федерации оставила решение в силе ${ }^{1}$.

По заявлению избирательной комиссии суд может отменить регистрацию кандидата, списка кандидатов при наличии предусмотренных законом обстоятельств.

В период проведения выборов депутатов Государственной Думы Федерального Собрания Российской Федерации пятого созыва по заявлению ЦИК России Верховным Судом Российской Федерации была отменена регистрация ряда кандидатов в депутаты Государственной Думы Федерального Собрания Российской Федерации, включенных в зарегистрированные федеральные списки

\footnotetext{
${ }^{1}$ По данному вопросу См. также Определение Верховного Суда Российской Федерации от 28 февраля 2009 г. № 16-ГО9-10 по кассационной жалобе представителя Регионального отделения политической партии «Справедливая Россия: Родина/Пенсионеры/Жизнь» в Волгоградской области на решение Волгоградского областного суда от 22 февраля 2009 г. об отмене регистрации кандидата в депутаты Волгоградской областной Думы по единому избирательному округу Ростова М.А.
} 
кандидатов, в связи с отсутствием у них гражданства Российской Федерации либо наличием гражданства иностранного государства ${ }^{1}$. В Определении от 4 декабря 2007 г. № 797-О-О «Об отказе в принятии к рассмотрению жалобы гражданина Кара-Мурзы Владимира Владимировича на нарушение его конституционных прав положением пункта 3.1 статьи 4 Федерального закона «Об основных гарантиях избирательных прав и права на участие в референдуме граждан Российской Федерации» Конституционный Суд Российской Федерации обосновал правомерность ограничения пассивного избирательного права в связи с наличием гражданства иностранного государства. По мнению Конституционного Суда, «поскольку гражданин Российской Федерации, имеющий гражданство иностранного государства, находится в политико-правовой связи одновременно с Российской Федерацией и с соответствующим иностранным государством, перед которым он также несет конституционные и иные, вытекающие из законов данного иностранного государства, обязанности, значение для него гражданства Российской Федерации как политико-юридического выражения ценности связи с Отечеством объективно снижается. Волеизъявление такого лица - в случае избрания его депутатом законодательного (представительного) органа государственной власти - в процессе реализации депутатских полномочий может обусловливаться не только требованиями конституционного правопорядка Российской Федерации и интересами еe народа, но и требованиями, вытекающими из принадлежности к иностранному государству. Между тем формально-юридическая либо фактическая подчиненность депутата законодательного (представительного) органа суверенной воле не только народа Российской Федерации, но и народа иностранного государства не согласуется с конституционными принципами независимости депутатского мандата и

\footnotetext{
1 См. Решение Верховного Суда Российской Федерации от 9 ноября 2007 г. № ГКПИ07-1426 по заявлению Центральной избирательной комиссии Российской Федерации об отмене регистрации кандидата в депутаты Государственной Думы Федерального Собрания Российской Федерации пятого созыва Наджаряна С.Н., включенного в зарегистрированный федеральный список кандидатов, выдвинутый политической партией «Либерально-демократическая партия России»; Решение Верховного Суда Российской Федерации от 24 ноября 2007 г. № ГКПИ07-1534 по заявлению Центральной избирательной комиссии Российской Федерации об отмене регистрации кандидата в депутаты Государственной Думы Федерального Собрания Российской Федерации пятого созыва Нисанова Г.С., включенного в зарегистрированный федеральный список кандидатов, выдвинутый политической партией «Либерально-демократическая партия России».
} 
государственного суверенитета и ставит под сомнение верховенство Конституции Российской Федерации». Аналогичное дело было разрешено Верховным Судом Российской Федерации по заявлению В.К. Буковского об отмене постановления Центральной избирательной комиссии Российской Федерации от 22 декабря 2007 г. № 80/644-5 «Об отказе в регистрации группы избирателей, созданной для поддержки самовыдвижения Буковского В.К. кандидатом на должность Президента Российской Федерации, и ее уполномоченных представителей» ${ }^{1}$.

Центральное место в обеспечении защиты конституционного строя России занимает совместная деятельность органов федеральной службы безопасности, прокуратуры и судов по противодействию экстремизму в процессе организации и проведения выборов. Установленный судом в рамках уголовного дела, возбужденного органами федеральной службы безопасности, Следственного комитета при прокуратуре Российской Федерации факт подготовки и совершения экстремистской деятельности в период выборов является основанием для отказа в регистрации кандидата, списка кандидатов, исключения из списка кандидатов либо отмены регистрации кандидата, списка кандидатов (подпункт «к» пункта 24, подпункт «и» пункта 25, подпункт «з» пункта 26 статьи 38, подпункт «д» пункта 7, подпункт «д» пункта 8 статьи 76 Федерального закона от 12 июня 2002 г. № 67Ф3).

Если суд установит, что гражданин в ходе избирательной кампании использовал агитацию экстремистского характера, он лишается пассивного избирательного права на срок полномочий органа государственной власти или органа местного самоуправления, в которые назначены выборы, либо должностного лица, для избрания которого назначены выборы (подпункт «г» пункта 3.2 статьи 4 Федерального закона от 12 июня 2002 г. № 67-Ф3). Подпунктом «в» пункта 2 статьи 77, пунктом 3 части 4 статьи 92 Федерального закона от 12 июня 2002 г. № 67-Ф3 предусмотрена возможность отмены судом решения Центральной избирательной комиссии Российской Федерации о результатах выборов депутатов Государственной Думы Федерального Собрания Российской

\footnotetext{
1 См. Решение Верховного Суда Российской Федерации от 28 декабря 2007 года по заявлению В.К. Буковского об отмене постановления Центральной избирательной комиссии Российской Федерации от 22 декабря 2007 г. № 80/644-5 «Об отказе в регистрации группы избирателей, созданной для поддержки самовыдвижения Буковского В.К. кандидатом на должность Президента Российской Федерации, и ее уполномоченных представителей».
} 
Федерации после определения их результатов в случае использования кандидатом, признанным избранным, избирательным объединением, выдвинувшим список кандидатов, допущенный к распределению депутатских мандатов, экстремистской агитации, если нарушение данных ограничений при проведении предвыборной агитации не позволяет выявить действительную волю избирателей. Конституционно-правовая ответственность не исключает применение уголовно-правовой (например, за публичные призывы к осуществлению террористической деятельности или публичное оправдание терроризма, публичные призывы к осуществлению экстремистской деятельности, возбуждение ненависти либо вражды, а равно унижение человеческого достоинства) ${ }^{1}$ либо административной (по статье 20.3 Кодекса Российской Федерации об административных правонарушениях) ответственности.

Так, в ходе выборов в Московскую областную Думу, проходивших 11 марта 2007 г., в помещении избирательного участка № 1763, расположенного в г. Одинцово, граждане Червочкин Ю.М., Климов С.В., Сидорин В.В. с целью воспрепятствования свободному осуществлению другими гражданами избирательных прав и работе избирательной комиссии развернули флаги с символикой Национал - большевистской партии, зажгли пиротехнические изделия, пытались разбрасывать листовки и перевернуть урну с бюллетенями, однако их противоправные действия были пресечены сотрудниками милиции. При этом данные граждане применили насилие к председателю избирательной комиссии - Стреляеву С. $\Phi^{2}$. По данному факту прокуратурой г. Одинцово Московской области было возбуждено уголовное дело по признакам преступления, предусмотренного п. «в» ч. 2 ст. 141 УК РФ. 15 марта 2007 г. Одинцовской городской прокуратурой Московской области Национал большевистской партии было вынесено предупреждение о недопустимости действий экстремистского характера. Учитывая неоднократность экстремистских проявлений со стороны Национал - большевистской партии, задокументированных прокуратурами г. Санкт-Петербурга, Челябинской области

\footnotetext{
${ }^{1}$ Данные составы преступлений предусмотрены статьями 205.2, 280 и 282 Уголовного кодекса Российской Федерации. партии.

2 См. Решение Московского городского суда от 19 апреля 2007 г. о запрете Национал-большевистской
} 
и Одинцовской городской прокуратурой Московской области, в суд было направлено заявление о запрете деятельности указанной партии. 19 апреля 2007 г. Московский городской суд запретил Национал-большевистскую партию, а 7 августа 2007 г. данное решение было оставлено в силе Верховным Судом Российской Федерации.

Заметную роль играет судебный контроль за финансированием выборов. При наличии данных о признаках преступлений, предусмотренных частями 2 и 3 статьи 160, статьей 172, статьей 174 Уголовного кодекса Российской Федерации орган внутренних дел или федеральной службы безопасности, выявивший эти преступления, возбуждает уголовное дело, расследует его и передает в суд. Осуществление правосудия по делам о нарушениях избирательных прав граждан и общественных объединений, связанных с финансированием выборов, положительно сказывается на защите конституционного строя.

Суды Российской Федерации принимают активное участие в обеспечении легитимности результатов выборов. При наличии соответствующих судебных решений избирательные комиссии признают итоги голосования, результаты выборов недействительными.

Существенный вклад в регулирование проблемных вопросов, касающихся конституционно-правовой основы организации и проведения выборов, в ориентирование государственных органов и избирательных комиссий всех уровней на единообразное применение норм избирательного законодательства вносит Конституционный Суд Российской Федерации ${ }^{1}$.

В соответствии со ст. 3 Федерального конституционного закона «О Конституционном Суде Российской Федерации» целями деятельности данного судебного органа являются:

- защита основ конституционного строя;

- основных прав и свобод человека и гражданина;

- обеспечение верховенства и прямого действия Конституции Российской Федерации на всей территории России.

1 См.: Бондарь Н.С. Конституционное правосудие как средство решения избирательных споров / Избирательное законодательство и выборы в регионах: теория и практика. М., 2005. С. 43-58; Зорькин В.Д. Право на свободные выборы в решениях Конституционного Суда Российской Федерации / Политические права и свободные выборы: Сб. докладов. М.: ИППП, 2005. С. 59-66; Марина Е.М., Фомин А.А. Обеспечение Конституционным Судом Российской Федерации правовой безопасности участников избирательного процесса / Актуальные проблемы политики и права. Сб. науч. статей. Пенза, 2003. Вып. 6. С. 188-192. 
Защита конституционного строя осуществляется Конституционным судом Российской Федерации путем конституционного судопроизводства и контроля.

В Постановлении Конституционного Суда Российской Федерации от 17 ноября 1998 г. № 26-П по делу о проверке конституционности отдельных положений Федерального закона от 21 июня 1995 г. «О выборах депутатов Государственной Думы Федерального Собрания Российской Федерации» рассматривается принцип пропорционального представительства ${ }^{1}$. По мнению Конституционного Суда Российской Федерации, демократическое большинство, на основе которого, по смыслу статей 1 и 3 Конституции Российской Федерации, должна определяться воля народа, выраженная им на выборах, и наличие которого необходимо для признания легитимности органа народного представительства, не может быть лишь относительным большинством. При этом Конституционный Суд подчеркивает, что демократия, основанная на политическом многообразии и многопартийности, исходит из необходимости существования оппозиции и не допускает монополии на власть.

В Постановлении от 27 апреля 1998 г. № 12-П Конституционный Суд Российской Федерации указал, что установление дополнительно к Конституции Российской Федерации в качестве условий приобретения гражданином пассивного избирательного права требований, связанных с достижением определенного возраста, продолжительности проживания на территории субъекта Российской Федерации, знания языка, ограничивает права и свободы человека и гражданина и выходит за рамки полномочий законодательного органа государственной власти субъекта Российской Федерации ${ }^{2}$.

К числу важнейших документов в рассматриваемой сфере следует отнести Постановление Конституционного Суда Российской Федерации от 25 декабря 2001 года № 17-П, которым признано не соответствующим Конституции Российской Федерации положение части 2 статьи 208 Гражданскопроцессуального кодекса РСФСР, на основании которого исключалась возможность обжалования в кассационном порядке судебных решений по делам о

\footnotetext{
${ }^{1}$ См. СЗ РФ. 1998. № 48. Ст. 5969.

${ }^{2}$ См. Постановление Конституционного Суда Российской Федерации от 27 апреля 1998 г. № 12-П по делу о проверке конституционности отдельных положений части 1 статьи 92 Конституции Республики Башкортостан, части 1 статьи 3 Закона Республики Башкортостан «О Президенте Республики Башкортостан» и статей 1 и 7 Закона Республики Башкортостан «О выборах Президента Республики Башкортостан» // Рос. газ. 1998. 6 мая.
} 
нарушениях избирательных прав граждан, не связанных с оспариванием результатов выборов или референдумов ${ }^{1}$.

В Постановлении Конституционного Суда Российской Федерации от 22 января 2002 года № 2-П содержится правовая позиция о недопустимости ущемления субъектами Российской Федерации гарантий избирательных прав граждан Российской Федерации. Конституционный Суд Российской Федерации подчеркнул, что «регулирование и защита прав и свобод граждан составляют ведение Российской Федерации, субъекты же Российской Федерации, реализуя свои полномочия в сфере защиты прав и свобод, находящейся в совместном ведении Российской Федерации и ее субъектов, не могут снижать уровень конституционных гарантий избирательных прав, обеспечиваемый в Российской Федерации согласно общепризнанным принципам и соответствующим положениям Конституции Российской Федерации». Далее Конституционный Суд отметил, что «условия реализации пассивного избирательного права гражданами Российской Федерации должны быть едиными на всей ее территории; субъект же Российской Федерации, устанавливая своими нормативными актами расходящиеся с федеральным регулированием дополнительные условия осуществления пассивного избирательного права, нарушает равенство избирательных прав граждан Российской Федерации» ${ }^{2}$.

Основополагающим для обеспечения единства правового пространства России, приведения субъектами Федерации законодательства в сфере избирательных прав граждан в соответствие с Конституцией России и федеральными законами, является Постановление Конституционного Суда Российской Федерации от 11 апреля 2000 г. № 6-П по проверке конституционности отдельных положений пункта 2 статьи 1, пункта 1 статьи 21 и пункта 3 статьи 22 Федерального закона «О прокуратуре Российской Федерации» в связи с запросом Судебной коллегии по гражданским делам Верховного Суда

${ }^{1}$ В соответствии с ч. 3 ст. 261 Гражданско-процессуального кодекса Российской Федерации от 14 ноября 2002 г. № 138-Ф3 кассационная жалоба на решение суда по делу о защите избирательных прав может быть подана в течение пяти дней со дня принятия судом решения.

${ }^{2}$ См. Постановление Конституционного Суда Российской Федерации от 22 января 2002 года № 2-П «По делу о проверке конституционности ч. 2 ст. 69 , ч. 2 ст. 70 и ст. 90 Конституции Республики Татарстан, а также п. 2 ст. 4 и п.8 ст. 21 Закона Республики Татарстан «О выборах депутатов Республики Татарстан» в связи с жалобой гражданина М.М.Салямова // Рос. газ. 2002. 31 января. 
Российской Федерации ${ }^{1}$. Согласно указанному Постановлению, суд по заявлению прокурора, содержащего требование о проверке соответствия закона субъекта Российской Федерации федеральному закону, вправе признать закон субъекта Российской Федерации противоречащим федеральному закону и не подлежащим применению, что влечет необходимость его приведения в соответствие с федеральным законом законодательным органом государственной власти субъекта Российской Федерации.

Существенную роль в защите конституционного строя в избирательном процессе играет Верховный Суд Российской Федерации.

В соответствии с пунктом 2 статьи 75 Федерального закона от 12 июня 2002 г. № 67-Ф3 и статьей 27 Гражданско-процессуального кодекса Российской Федерации решения и действия Центральной избирательной комиссии Российской Федерации обжалуются в Верховный Суд Российской Федерации.

Неисполнение решения Верховного Суда Российской Федерации является основанием для расформирования Центральной избирательной комиссии Российской Федерации.

На основании части 9 статьи 38 Федерального закона от 18 мая 2005 г. № 51-Ф3 Верховный Суд Российской Федерации принимает решение по жалобам политических партий об отказе в заверении федерального списка кандидатов. В Верховный Суд Российской Федерации может быть обжаловано решение Центральной избирательной комиссии Российской Федерации о регистрации федерального списка кандидатов либо об отказе в его регистрации (часть 7 статьи 44 Федерального закона от 18 мая 2005 г. № 51-Ф3).

Статьей 91 комментируемого Федерального закона определяются обстоятельства, при установлении которых Верховный Суд Российской Федерации может отменить решения Центральной избирательной комиссии Российской Федерации о регистрации списка кандидатов, об отказе в его регистрации, об исключении группы кандидатов из списка кандидатов. Формулировки частей 7-10 статьи 91 Федерального закона от 18 мая 2005 г. № 51Ф3 допускают возможность выборочного правоприменения и нарушения равного статуса субъектов избирательного процесса. В соответствии с подпунктом «б»

\footnotetext{
${ }^{1}$ См. Рос. газ. 2000. 27 апр.
} 
пункта 8 Методики проведения экспертизы проектов нормативных правовых актов и иных документов в целях выявления в них положений, способствующих созданию условий для проявления коррупции, утвержденной Постановлением Правительства Российской Федерации от 5 марта 2009 г. № 196, диспозитивное установление возможности совершения органом государственной власти действий в отношении граждан и организаций является коррупционным фактором. Поэтому словосочетание «может быть» в частях 7-10 статьи 91 предлагается заменить словосочетанием «должно быть».

Принципиальное значение для защиты конституционного строя Российской Федерации имеют вопросы приостановления деятельности и ликвидации политических партий ${ }^{1}$. При наличии предусмотренных законом оснований Верховный Суд Российской Федерации принимает решение о ликвидации политической партии. Основания и порядок ликвидации политической партии закреплены пунктами 3-6 статьи 41 Федерального закона «О политических партиях» ${ }^{2}$. В соответствии со статьей 41 Федерального закона «О политических партиях» политическая партия может быть ликвидирована по решению Верховного Суда Российской Федерации в случае:

a) невыполнения требований закона, связанных с недопустимостью создания и деятельности структурных подразделений политических партий в органах государственной власти, органах местного самоуправления (за исключением деятельности в законодательных органах государственной власти и представительных органах муниципальных образований), в Вооруженных Силах Российской Федерации, в правоохранительных и иных государственных органах, в государственных и негосударственных организациях, а также вмешательства политических партий в учебный процесс образовательных учреждений.

\footnotetext{
1 Подробней см.: Агафонова K.A. Приостановление и ликвидация в системе мер юридической ответственности политических партий в Российской Федерации / Очерки сравнительно-исторического правоведения. Межкаф. сб. факультета права ГУ-ВШЭ. Вып. 2. М., 2005. С. 37-47.

${ }^{2}$ См.: Хертуев Р.Ю. Основания ликвидации политических партий / Актуальные проблемы правотворчества и правоприменительной деятельности. Материалы науч-практ. конф. Иркутск, 2008. С. 41-45.
} 
б) неустранения в установленный решением суда срок нарушений, послуживших основанием для приостановления деятельности политической партии;

в) неучастия политической партии в выборах;

г) отсутствия более чем в половине субъектов Российской Федерации региональных отделений политической партии, в которых число членов политической партии соответствует требованию закона;

д) отсутствия необходимого числа членов политической партии;

е) неоднократного непредставления политической партией в установленный срок в федеральный уполномоченный орган обновленных сведений, необходимых для внесения изменений в единый государственный реестр юридических лиц, за исключением сведений о полученных лицензиях.

На основании судебного решения о приостановлении деятельности или ликвидации политической партии, выдвинувшей федеральный список кандидатов, ЦИК России аннулирует регистрацию соответствующего федерального списка кандидатов.

В Федеральном законе «О политических партиях» также закреплены основания, при которых политическая партия и региональное отделение политической партии не могут быть ликвидированы. Политическая партия, федеральный список которой на выборах депутатов Государственной Думы Федерального Собрания Российской Федерации был допущен к распределению депутатских мандатов, не может быть ликвидирована по основаниям отсутствия необходимого числа членов политической партии и отсутствия региональных отделений с установленной законом численностью членов более чем в половине субъектов Российской Федерации, в течение четырех лет со дня голосования на указанных выборах.

Не допускается ликвидация политической партии по решению Верховного Суда Российской Федерации со дня официального опубликования решения о назначении (проведении) выборов депутатов Государственной Думы Федерального Собрания Российской Федерации, выборов Президента Российской 
Федерации до дня официального опубликования результатов указанных выборов, за исключением случаев осуществления партией экстремистской деятельности. Региональное отделение политической партии не может быть ликвидировано по решению суда со дня официального опубликования решения о назначении (проведении) выборов депутатов законодательного (представительного) органа соответствующего субъекта Российской Федерации и до дня официального опубликования результатов соответствующих выборов, за исключением случаев осуществления региональным отделением партии экстремистской деятельности.

Особого внимания и оценки заслуживают решения Верховного Суда Российской Федерации о признании ряда организаций, в том числе иностранных и международных, террористическими и запрете их деятельности на территории Российской Федерации. Такие решения принимались Верховным Судом Российской Федерации 14 февраля 2003 г., 2 июня 2006 г. и 13 ноября 2008 г. Единый федеральный список организаций, признанных террористическими, обнародуется Правительством Российской Федерации ${ }^{1}$.

Важной гарантией соблюдения прав и свобод человека и гражданина, обеспечения законности деятельности правоохранительных органов в избирательном процессе является судебный контроль. Проведение оперативнорозыскных мероприятий, которые ограничивают конституционные права граждан на тайну переписки, телефонных переговоров, почтовых, телеграфных и иных сообщений, передаваемых по сетям электрической и почтовой связи, а также право на неприкосновенность жилища, допускается только на основании судебного решения ${ }^{2}$.

Центральное место среди субъектов защиты конституционного строя в избирательном процессе занимают органы прокуратуры. Оно обусловлено

${ }^{1}$ См. Распоряжение Правительства Российской Федерации от 14 июля 2006 г. № 1014-р «Об обнародовании Единого федерального списка организаций, признанных террористическими» // СЗ РФ. 2006. № 29. Ст. 3283; Распоряжение Правительства Российской Федерации от 15 октября 2007 г. (в ред. от 8 декабря 2008 г.) № 1420-р «Об официальном периодическом издании, осуществляющем публикацию перечня общественных и религиозных объединений, иных организаций, в отношении которых судом принято вступившее в законную силу решение о ликвидации или запрете деятельности по основаниям, предусмотренным Федеральным законом «О противодействии экстремистской деятельности», и перечня общественных и религиозных объединений, деятельность которых приостановлена в связи с осуществлением ими экстремистской деятельности» // СЗ РФ. 2007. № 43. Ст. 5256; 2008. № 50. Ст. 5958.

2 См. ч. 2 ст. 8 Федерального закона от 12 августа 1995 г. № 144-Ф3 «Об оперативно-розыскной деятельности». 
координирующей ролью прокуратуры в деятельности правоохранительных органов по борьбе с преступностью, спецификой сферы правового регулирования прокурорского надзора за соблюдением законодательства о выборах, а также установленными законодательством полномочиями прокурора по осуществлению надзорной деятельности.

Прокурорский надзор за соблюдением законодательства о выборах выступает в качестве особой составляющей в деятельности органов прокуратуры ${ }^{1}$. Во-первых, прокурорский надзор за соблюдением законодательства о выборах является подотраслью общего надзора, т.е. надзора за точным и единообразным исполнением законов всеми субъектами права (гражданами, организациями, государственными органами, органами местного самоуправления и должностными лицами).

Во-вторых, данное направление прокурорского надзора можно рассматривать в качестве подотрасли надзора за соблюдением прав и свобод человека и гражданина.

Надзор за соблюдением законодательства о выборах является направлением реализации государственной политики в сфере защиты конституционного строя. При его осуществлении прокурор решает общие задачи, определенные статьями 1, 21 и 27 Закона Российской Федерации «О прокуратуре Российской Федерации» (в ред. от 28 ноября 2009 г.). Он вмешивается лишь в случаях, требующих принятия мер прокурорского реагирования (опротестовывает незаконные правовые акты, направляет в целях защиты публичного интереса заявления в судебные органы, вносит представления, решает в установленном порядке вопрос о привлечении нарушителей избирательного законодательства к административной или уголовной ответственности) $)^{2}$. В соответствии с Приказом

\footnotetext{
${ }^{1}$ См.: Дмитриев Ю.А., Исраелян В.Б. Избирательное право и процесс в Российской Федерации. Ростов-наДону: Феникс, 2004. С. 820-826.

2 См. Письмо Генеральной прокуратуры Российской Федерации от 22 декабря 2003 г. № 36-12-03 «О Методических рекомендациях «Осуществление прокурорского надзора за соблюдением избирательных прав граждан»; Указание Генерального прокурора Российской Федерации от 28 сентября 2007 г. № $153 / 7$ «Об организации прокурорского надзора за соблюдением законодательства о выборах депутатов Государственной Думы Федерального Собрания Российской Федерации»; Указание Генерального прокурора Российской Федерации от 16 января 2008 г. № 4/7 «Об организации прокурорского надзора за соблюдением законодательства о выборах Президента Российской Федерации».
} 
Генерального прокурора от 15 сентября 2004 г. № 24 «О порядке предоставления специальных донесений о чрезвычайных происшествиях и преступлениях, а также иной обязательной информации в органах прокуратуры Российской Федерации» прокуроры субъектов Российской Федерации и приравненных к ним специализированных прокуратур обязаны незамедлительно направлять в Генеральную прокуратуру Российской Федерации специальные донесения о чрезвычайных происшествиях и преступлениях в сфере избирательного процесса, аналитические справки о комплексном изучении состояния законности в регионе в период предвыборной кампании и проведения выборов.

В области защиты избирательных прав граждан задачи прокурорского надзора включают два основных направления: надзор за соответствием федеральным законам нормативных правовых актов, издаваемых ЦИК Российской Федерации и другими избирательными комиссиями, и надзор за законностью действий избирательных комиссий всех уровней, органов власти, политических партий и общественных объединений при реализации законов о выборах.

При обращении в суд с заявлением о признании противоречащего федеральному законодательству регионального либо муниципального нормативного правового акта недействующим полностью или в части со дня его принятия или иного указанного судом времени прокуроры руководствуются положениями статей 45, 245-253 ГПК РФ, статьями 52, 191-196 АПК РФ, регулирующими производство по делам, возникающим из публичных правоотношений.

Анализ прокурорско-судебной практики и изучение материалов проведенных избирательных кампаний свидетельствуют, что сотрудничество органов юстиции, федеральной службы безопасности и органов внутренних дел с прокуратурой по защите конституционного строя в период выборов, как правило, осуществляется в следующих случаях: 
во-первых, при подготовке заключений органами юстиции о соответствии действующему законодательству изданных на местах нормативных правовых актов и передаче собранных материалов в прокуратуру ${ }^{1}$;

во-вторых, при осуществлении антикоррупционной экспертизы нормативных правовых актов субъектов правотворчества;

в-третьих, при выявлении органами внутренних дел и федеральной службы безопасности подготавливаемых, совершаемых или совершенных деяний, содержащих признаки преступлений или административных правонарушений в сфере выборов, и информировании прокуратуры для принятия соответствующих мер реагирования;

в-четвертых, при расследовании следователями Следственного комитета при прокуратуре, федеральной службы безопасности и органов внутренних дел преступлений альтернативной подследственности, связанных с выборами (как правило, по составам ст.ст. 105, 160, 167, 205, 205.1, 205.2, 207, 212, 272-274, 277280, 282, 282.1, 282.2 УК РФ).

В пунктах 18, 18.1 статьи 29 Федерального закона от 12 июня 2002 г. № 67Ф3 закреплены гарантии неприкосновенности членов избирательных комиссий с правом решающего голоса при привлечении к уголовной и административной ответственности. Специальный порядок привлечения указанных лиц к уголовной ответственности требует согласия руководителя следственного органа Следственного комитета при прокуратуре Российской Федерации по субъекту Российской Федерации (Председателя Следственного комитета при прокуратуре Российской Федерации), а к административной ответственности, налагаемой в судебном порядке - согласия прокурора субъекта Российской Федерации (Генерального прокурора Российской Федерации).

1 В целях обеспечения верховенства Конституции Российской Федерации и федеральных законов в Российской Федерации Указом Президента Российской Федерации от 10 августа 2000 г. № 1486 «О дополнительных мерах по обеспечению единства правового пространства Российской Федерации» на Министерство юстиции возложено ведение федерального банка нормативных правовых актов субъектов Российской Федерации (федерального регистра). См. также Приказ Генеральной прокуратуры Российской Федерации от 2 октября 2007 г. № 155 «Об организации прокурорского надзора за законностью нормативных правовых актов органов государственной власти субъектов Российской Федерации и местного самоуправления». [Текст приказа не опубликован.] 
Глава 52 Уголовно-процессуального кодекса Российской Федерации устанавливает особенности производства по уголовным делам, возбужденным в отношении кандидата в Президенты Российской Федерации, зарегистрированного кандидата в депутаты Государственной Думы Федерального Собрания Российской Федерации, зарегистрированных кандидатов в депутаты законодательного органа государственной власти субъекта Российской Федерации.

Надзор прокуроров за законностью возбуждения и расследования уголовных дел, связанных с выборами, играет важную роль в защите конституционного строя в избирательном процессе. Надзор за исполнением правоохранительными органами законов в ходе осуществления деятельности по защите конституционного строя Российской Федерации в период выборов осуществляют Генеральный прокурор Российской Федерации и уполномоченные им прокуроры.

В число компетентных субъектов защиты конституционного строя в избирательном процессе входят и налоговые органы ${ }^{1}$.

Пункты 23 и 24 Постановления Правительства Российской Федерации от 17 сентября 2007 г. № 589, пункт 1 части 9 статьи 68 Федерального закона от 18 мая 2005 г. № 51-Ф3 предписывают налоговым органам предоставлять по обращениям ЦИК Российской Федерации копии сводных финансовых отчетов политических партий, зарегистрировавших федеральные списки кандидатов, выдвинувших зарегистрированных кандидатов на должность Президента Российской Федерации, а также имеющиеся сведения о результатах проверок сводных финансовых отчетов, в том числе о выявленных нарушениях финансовой деятельности указанных политических партий².

\footnotetext{
1 См. также Абанин О.А., Рейдель Л.Б. Взаимодействие избирательных комиссий с органами государственной власти и органами местного самоуправления // Правовая политика и правовая жизнь. 2008 . № 4. C. $46-52$.

${ }^{2}$ См. Приказ Министра по налогам и сборам Российской Федерации от 31 января 2003 г. № БГ-3-06/41 «Об утверждении формы сводного финансового отчета политической партии и порядка заполнения сводного финансового отчета политической партии»; Приказ Федеральной налоговой службы от 10 августа 2007 г. № ММ-304/474 «Об организации работы по оказанию содействия Центральной избирательной комиссии Российской Федерации в проверке достоверности сведений о размере и об источниках доходов, имуществе, принадлежащем кандидату на праве собственности, о вкладах в банках, ценных бумагах, представляемых кандидатами в депутаты Государственной Думы Федерального Собрания Российской Федерации пятого созыва».
} 
В соответствии с Соглашением между Центральной избирательной комиссией Российской Федерации и Федеральной налоговой службой о взаимодействии и взаимном обмене информацией в период проведения федеральных избирательных кампаний 2007-2008 годов от 2 июля 2007 г. № 4242/ММ-25-04/6 Федеральная налоговая служба на основании представленных ЦИК России данных осуществляет проверку и сбор имеющейся в базах данных налоговых органов информации: о размере и об источниках доходов кандидата (каждого кандидата из списка кандидатов) и его супруга; об имуществе (зданиях, сооружениях, жилых и нежилых помещениях, земельных участках и ином недвижимом имуществе), принадлежащем кандидату (каждому кандидату из списка кандидатов) и его супругу на праве собственности (в том числе совместной собственности); об участии кандидата (каждого кандидата из списка кандидатов) и его супруга в капитале коммерческих организаций.

Пункт 3 статьи 38 Федерального закона от 10 января 2003 г. № 19-Ф3, часть 7 статьи 43 Федерального закона от 18 мая 2005 г. № 51-Ф3 закрепляют необходимость взаимодействия избирательных комиссий с Министерством юстиции и его территориальными органами. Органы юстиции проверяют сведения, содержащиеся в документах, представляемых на государственную регистрацию политическими партиями и другими общественными объединениями, в случаях, когда имеются основания сомневаться в их достоверности.

Чрезвычайно важным элементом деятельности органов юстиции по защите конституционного строя в избирательном процессе является их участие в противодействии иностранному и другому нелегальному финансированию политической деятельности в России со стороны иностранных неправительственных некоммерческих организаций. Действующее законодательство позволяет компетентным органам проводить подобную работу. В соответствии с пунктами 3-4 статьи 32 Федерального закона «О некоммерческих организациях» некоммерческая организация обязана 
представлять в уполномоченный орган в сфере юстиции документы, содержащие отчет о своей деятельности, о персональном составе руководящих органов, а также документы о расходовании денежных средств и об использовании иного имущества, в том числе полученных от международных и иностранных организаций, иностранных граждан и лиц без гражданства ${ }^{1}$. Структурное подразделение иностранной некоммерческой неправительственной организации обязано информировать уполномоченный орган об объеме получаемых данным подразделением денежных средств и иного имущества, их предполагаемом распределении, о целях их расходования или использования и об их фактическом расходовании или использовании, о предполагаемых для осуществления на территории Российской Федерации программах, a также о расходовании предоставленных физическим и юридическим лицам указанных денежных средств и об использовании предоставленного им иного имущества по форме и в сроки, которые устанавливаются Правительством Российской Федерации.

В случае несоответствия характера деятельности и расходов филиала или представительства иностранной некоммерческой неправительственной организации заявленным целям такое структурное подразделение по решению уполномоченного органа может быть исключено из реестра филиалов и представительств международных организаций и иностранных неправительственных организаций.

Эффективной мерой борьбы с попытками оказания из-за рубежа конспиративного целенаправленного информационно-пропагандистского, финансового, политического и силового воздействия на избирательный процесс в ущерб конституционному строю России может служить предусмотренная пунктом 12 статьи 32 Федерального закона «О некоммерческих организациях» возможность запрета осуществления на территории Российской Федерации программ иностранных неправительственных организаций, создающих угрозу суверенитету, политической независимости, территориальной

${ }^{1}$ См. СЗ РФ. 1996. № 3. Ст. 145; 1998. № 48. Ст. 5849; 1999. № 28. Ст. 3473; 2002. № 52 (ч. 2). Ст. $5141 ; 2003$. № 52 (ч. 1). Ст. 5031; 2006 . № 3. Ст. 282; 2006. № 45. Ст. 4627; 2007. № 1 (ч. 1). Ст. 37; 2007. № 10. Ст. $1151 ; 2007$. № 22. Ст. 2563; 2007. № 49. Ст. 6061; 2008. № 20. Ст. 2253; 2008. № 30 (ч. 2). Ст. 3616; 2009. № 23. Ст. $2762 ; 2009$. № 29. Ст. 3607. 
неприкосновенности и национальным интересам Российской Федерации. Уполномоченный орган в сфере юстиции направляет структурному подразделению иностранной некоммерческой неправительственной организации в письменной форме мотивированное решение о запрете осуществления на территории Российской Федерации заявленной для осуществления на территории Российской Федерации программы или ее части. Невыполнение указанного решения влечет за собой исключение соответствующего филиала или представительства иностранной некоммерческой неправительственной организации из реестра, ликвидацию отделения иностранной некоммерческой неправительственной организации.

В целях защиты конституционного строя уполномоченный орган вправе вынести структурному подразделению иностранной некоммерческой неправительственной организации в письменной форме мотивированное решение о запрете направления денежных средств и иного имущества определенным получателям указанных средств и иного имущества.

Отдельно следует рассмотреть сотрудничество органов внутренних дел, органов федеральной службы безопасности и избирательных комиссий в интересах защиты конституционного строя в ходе выборов.

Действующее законодательство определяет полномочия органов внутренних дел в процессе организации и проведения выборов как оказание содействия работе избирательных комиссий. Конкретные формы и методы работы органов внутренних дел в этом направлении обусловлены этапами избирательной кампании ${ }^{1}$.

Организационные и практические мероприятия по осуществлению контроля за соблюдением установленных правил паспортно-регистрационной системы органы внутренних дел реализуют в тесном взаимодействии с органами ФМС, ФСБ, прокуратуры, учреждениями государственной статистики, военными комиссариатами, жилищно-эксплуатационными организациями

${ }^{1}$ См.: Бутаев В.И., Волков В.П., Шебунова В.Я. Методическое пособие по оказанию органами внутренних дел содействия избирательным комиссиям в реализации их полномочий и проведении выборов органов государственной власти и органов местного самоуправления. М.: РЦОИТ при ЦИК России, 2007. 112 с; Долгий $O . B$. О взаимодействии органов внутренних дел с участковыми избирательными комиссиями // Вестник Дальневосточного юрид. ин-та МВД России. 2008. № 1. С. 72-76. 
общественностью, а в пограничных зонах — также с подразделениями и частями органов Пограничной службы ФСБ России ${ }^{1}$. В процессе реализации этих мероприятий органы внутренних дел принимают участие в предупреждении правонарушений, связанных с выборами; выявлении лиц, подозреваемых в совершении преступлений и скрывающихся от органов дознания, следствия и суда либо проживающих по подложным или поддельным документам; розыске конкретных лиц, известных органам внутренних дел и федеральной службы безопасности и т. ${ }^{2}$.

В период организации и проведения выборов органы внутренних дел обследуют объекты хранения денежных средств, огнестрельного оружия, боеприпасов, взрывчатых веществ, наркотических средств, психотропных и ядовитых веществ. По каждому объекту совместно с органами федеральной службы безопасности разрабатываются и осуществляются конкретные мероприятия по усилению их охраны. В местах со сложной криминогенной обстановкой в период избирательной кампании организуется проведение оперативно-розыскных, профилактических и иных мероприятий, направленных на предупреждение и пресечение тяжких и особо тяжких преступлений.

Ужесточается оперативный контроль за обстановкой в аэропортах. Проводится анализ уязвимости предприятий с опасным циклом производства, метро, гидротехнических сооружений и других стратегических объектов от террористических атак. Проводится оперативно-профилактическая работа с лидерами радикальных организаций, ранее судимыми, наркоманами, лицами с психическими заболеваниями, владельцами огнестрельного оружия на территории проведения общественно-политического мероприятия, связанного с проведением выборов, и прилегающих районах. Усиливается пограничный и таможенный контроль в пунктах пропуска через границу в целях выявления и

\footnotetext{
1 В соответствии с Положением о Федеральной миграционной службе России, утвержденным Указом Президента Российской Федерации от 19 июля 2004 г., ФМС России подведомственна МВД Российской Федерации.

2 См.: Алексеев Н.A. Организационно-правовые основы взаимодействия органов внутренних дел с избирательными комиссиями: Автореф. дис. ... канд. юр. наук / Моск. Акад. МВД России. М., 2001. 26 с
} 
недопущения въезда в страну лиц, пытающихся провести оружие, взрывчатые и отравляющие вещества ${ }^{1}$.

Для различных общественных объединений подбираются места проведения массовых акций. Это позволяет локализовать и свести к минимуму возможность организации беспорядков и других экстремистских проявлений. С одной стороны, обеспечиваются конституционные права граждан на выражение своего мнения и протестных настроений, с другой стороны, - не допускается нарушение общественного порядка ${ }^{2}$.

По запросам избирательных комиссий органы внутренних дел проверяют наличие у кандидатов неснятых (непогашенных) судимостей, сведения о транспортных средствах, находящихся в собственности кандидатов, предоставляют материалы оперативно-справочных учетов Главного информационного центра МВД России, информационных центров МВД, ГУВД, УВД субъектов Российской Федерации в отношении обвиняемых в совершении преступлений, осужденных, разыскиваемых, рассматривают представления избирательных комиссий о нарушениях законодательства ${ }^{3}$ В большинстве субъектов Российской Федерации были подписаны соглашения о взаимодействии между избирательными комиссиями субъектов Российской Федерации и территориальными органами внутренних дел (Республика Карелия, Республика Марий Эл, Чувашская Республика, Белгородская, Воронежская, Свердловская, Тверская области и др.). Во многих регионах представителям избирательных комиссий обеспечен доступ к сведениям о гражданах, имеющимся в паспортновизовых службах и адресно-справочных бюро. Одновременно предусмотрена возможность использования органами внутренних дел каналов подсистемы связи и передачи данных ГАС «Выборы» ${ }^{4}$.

\footnotetext{
1 См. Документы VII Совещания руководителей специальных служб, органов безопасности и правоохранительных органов по проблемам борьбы с терроризмом. М.: Граница, 2008. С. 94.

2 Там же. С. 95.

3 См.: Положение о Главном информационном центре МВД Российской Федерации, утвержденное Приказом Министра внутренних дел Российской Федерации от 7 декабря 1998 г. № 797; Приказ Министра внутренних дел Российской Федерации от 26 сентября 2007 г. № 835 «О порядке исполнения органами внутренних дел Российской Федерации представлений избирательных комиссий».

${ }^{4}$ См. Выписка из протокола заседания ЦИК России от 7 октября 2005 г. № 155-1-4 «О ходе реализации Протокола № 1 к Соглашению о взаимодействии Центральной избирательной комиссии Российской Федерации и Министерства внутренних дел Российской Федерации».
} 
В день голосования субъекты защиты конституционного строя в избирательном процессе (прежде всего, избирательные комиссии и органы внутренних дел) особое внимание уделяют избирательным участкам. В этот период основные усилия правоохранительных органов направлены на реализацию оперативно-профилактических мер, связанных с недопущением террористических актов, экстремистских проявлений, подкупа участников выборов, незаконной выдачи гражданам избирательных бюллетеней, незаконного вмешательства в деятельность избирательных комиссий, а также обеспечением безопасности членов комиссий.

Должностные лица органов внутренних дел (милиции) вправе составлять протоколы об административных правонарушениях в сфере избирательного права, предусмотренных статьями 5.6, 5.10, 5.11, 5.12, 5.14, 5.15, 5.16, 5.22, 5.47, 5.49 Кодекса Российской Федерации об административных правонарушениях.

В период выборов у избирательных комиссий и правоохранительных органов возникает необходимость сотрудничества с государственными (муниципальными) организациями телерадиовещания и периодическими печатными изданиями.

Государственные и муниципальные организации, осуществляющие теле- и (или) радиовещание, и (или) редакции государственных и муниципальных периодических печатных изданий обязаны предоставлять избирательным комиссиям бесплатное эфирное время для информирования избирателей, а также бесплатную печатную площадь для опубликования их решений и актов, размещения иной печатной информации.

Возможности государственных СМИ или СМИ с частичным государственным и (или) муниципальным участием должны использоваться комиссиями и правоохранительными органами: во-первых, в интересах укрепления доверия населения к избирательному процессу, сбалансированного информационного освещения выборов, избирательных кампаний кандидатов, политических партий без проявления политических или иных предпочтений; во-вторых, для установления обстоятельств преступлений, а также лиц, их совершивших, для розыска лиц, скрывшихся от дознания, следствия и суда, и лиц, без вести пропавших; в-третьих, для осуществления информационно-пропагандистских мероприятий по повышению 
бдительности граждан и разъяснению их действий в случае террористических и иных экстремистских угроз; в-четвертых, для формирования положительного образа правоохранительных органов и спецслужб и стимулирования содействия населения законной деятельности компетентных органов. Важно соблюдать обязательную грань между информационным обеспечением защиты конституционного строя и реализацией политических конъюнктурных целей отдельных кандидатов (избирательных объединений). Нельзя допустить использования компетентных органов в качестве инструмента ведения «войны компроматов». В любых обстоятельствах правоохранительные органы и спецслужбы должны быть независимы от политических установок каких-либо кандидатов и партий.

В интересах потенциального использования в качестве доказательств по уголовным делам законодатель устанавливает обязательные сроки хранения материалов теле- и радиопрограмм в период выборов ${ }^{1}$. Согласно пункту 26 статьи 52 Федерального закона от 10 января 2003 г. № 19-Ф3, части 26 статьи 58 Федерального закона от 18 мая 2005 г. № 51-Ф3 видео- и аудио-записи выпущенных в эфир теле- и радиопрограмм, содержащих предвыборную агитацию, хранятся в соответствующей организации телерадиовещания не менее 12 месяцев со дня официального опубликования общих результатов выборов. В связи с необходимостью производства предварительного расследования организации телерадиовещания обязаны бесплатно предоставлять копии указанных теле- и радиопрограмм.

Осуществление контроля за порядком финансирования выборов вызывает необходимость взаимодействия избирательных комиссий и политических партий с учреждениями Центрального банка Российской Федерации (в случае их отсутствия - с филиалами Сберегательного банка Российской Федерации) $)^{2}$.

По согласованию с Центральным банком Российской Федерации ЦИК России устанавливает порядок открытия и ведения счетов, учета, отчетности и

\footnotetext{
${ }^{1}$ См.: Волков В.П., Дамаскин О.В., Шапиев С.М. Некоторые проблемы и пути их решения для обеспечения законности избирательного процесса в Российской Федерации. М., 2009. С. 84-85, 99

${ }^{2}$ См. Письмо Центрального Банка Российской Федерации от 28 сентября 2007 г. № 154-Т «О Постановлении Правительства Российской Федерации».
} 
перечисления денежных средств, выделенных из федерального бюджета избирательным комиссиям на подготовку и проведение выборов в федеральные органы государственной власти, эксплуатацию и развитие средств автоматизации, обучение организаторов выборов и избирателей и обеспечение деятельности избирательных комиссий. Порядок открытия и ведения счетов, учета, отчетности и перечисления денежных средств, выделенных из бюджета субъекта Российской Федерации, местного бюджета избирательным комиссиям на подготовку и проведение выборов в органы государственной власти субъекта Российской Федерации, в органы местного самоуправления, эксплуатацию и развитие средств автоматизации, обучение организаторов выборов и избирателей и обеспечение деятельности избирательных комиссий, устанавливается избирательной комиссией субъекта Российской Федерации по согласованию с главным управлением (национальным банком) Центрального банка Российской Федерации в субъекте Российской Федерации. Денежные средства перечисляются на счета, открываемые комиссиям в учреждениях Центрального банка Российской Федерации (в случае их отсутствия - в филиалах Сберегательного банка Российской Федерации) ${ }^{1}$.

Согласно части 5 статьи 65 Федерального закона от 18 мая 2005 г. № 51-Ф3 политическая партия открывает специальный избирательный счет на основании документа, выдаваемого Центральной избирательной комиссией Российской Федерации в течение 3 дней после заверения ею федерального списка кандидатов и регистрации уполномоченных представителей политической партии по финансовым вопросам. Региональное отделение политической партии открывает специальный избирательный счет на основании документа, выдаваемого избирательной комиссией субъекта Российской Федерации в течение 3 дней после представления в избирательную комиссию субъекта Российской Федерации копии заверенного федерального списка кандидатов, заверенного списка уполномоченных представителей регионального отделения политической партии по финансовым вопросам и регистрации этих уполномоченных

\footnotetext{
${ }^{1}$ См. Пункт 7 статьи 57 Федерального закона от 12 июня 2002 г. № 67-Ф3.
} 
представителей. Филиалы Сберегательного банка Российской Федерации по требованию избирательных комиссий и официальным запросам правоохранительных органов периодически предоставляют сведения о поступлении и расходовании средств избирательных фондов. Избирательные комиссии направляют эту информацию в СМИ для опубликования.

Если политическая партия не представила в ЦИК России документы, необходимые для регистрации выдвинутого ею федерального списка кандидата, либо получила отказ в регистрации, либо отозвала федеральный список кандидатов, а также если регистрация указанного списка была отменена или аннулирована, все финансовые операции по специальному избирательному счету прекращаются филиалом Сберегательного банка Российской Федерации по указанию ЦИК России. В случае исключения региональной группы из федерального списка кандидатов избирательная комиссия субъекта Российской Федерации прекращает финансовые операции по избирательному счету регионального отделения политической партии.

Порядок открытия, ведения и закрытия специальных избирательных счетов определяется Центральной избирательной комиссией Российской Федерации по согласованию с Центральным банком Российской Федерации.

В субъектах Российской Федерации избирательные комиссии и правоохранительные органы в процессе выборов сотрудничают с органами государственной власти субъектов Российской Федерации и антитеррористическими комиссиями субъектов Российской Федерации ${ }^{1}$.

Проведенный анализ нормативного правового регулирования участия компетентных государственных органов и учреждений в защите конституционного строя в избирательном процессе свидетельствует о том, что деятельность всех субъектов защиты конституционного строя определяется соответствующими законодательными и подзаконными нормативными правовыми актами. Содержание этих нормативных актов определяет задачи субъектов защиты конституционного строя в ходе избирательных кампаний,

\footnotetext{
1 См.: Документы VII Совещания руководителей специальных служб, органов безопасности и правоохранительных органов по проблемам борьбы с терроризмом. М.: Граница, 2008. С. 84.
} 
устанавливает их функции и полномочия в период выборов, закрепляет порядок использования ими специальных сил и средств, формы взаимодействия с другими государственными органами (негосударственными организациями) и механизм контроля.

\section{Выводы:}

1. Проблема правового обеспечения защиты конституционного строя в избирательном процессе, несмотря на ее политико-правовую значимость, стала разрабатываться сравнительно недавно. В советский период избирательный процесс был формализован, реальных угроз конституционному строю в условиях выборов не возникало. В 90-е гг. ХХ в. исследования не проводились в связи со становлением нового конституционного строя, отсутствием долгосрочной стратегии политического развития государства и ошибочными представлениями руководства страны о фиктивности угроз конституционному строю России в избирательном процессе. Недостаток знаний, обеспечивающих системность и полноту научных исследований проблемы правовой защиты конституционного строя в избирательном процессе, остро проявился в связи с использованием отдельными иностранными государствами технологий захвата политической власти в условиях выборов для осуществления «цветных» революций. С этого момента разработка проблемы правового обеспечения защиты конституционного строя в избирательном процессе вышла на качественно иной уровень. Методология исследований стала носить комплексный характер и включила в себя не только противодействие иностранному вмешательству в избирательный процесс, но и ориентацию на деструктивные внутриполитические явления политической системы российского общества (монополизацию политической власти, партийную коррупцию, криминализацию государственного аппарата, экстремизм и др.).

На современном этапе изучение общего состояния правового обеспечения защиты конституционного строя России в избирательном процессе необходимо осуществлять на основе анализа результатов правотворческой деятельности 
государства в связи с возрастающими потребностями в защите конституционного строя и возможностями правоприменительной практики.

В настоящее время правовое обеспечение защиты конституционного строя России в избирательном процессе осуществляется совокупностью законодательных и подзаконных нормативных правовых актов, которые можно классифицировать на три группы:

- нормативные правовые акты, определяющие общие принципы, функции и систему защиты конституционного строя России в избирательном процессе;

- нормативные правовые акты, устанавливающие гарантии законности прохождения избирательного процесса, свободной реализации избирательных прав, а также обеспечивающие защиту демократических принципов и норм избирательного права;

- нормативные правовые акты, регламентирующие правовой статус, задачи и возможные формы участия государственных (в том числе правоохранительных) органов и учреждений в защите конституционного строя России в условиях выборов.

2. Конституционно-правовой механизм защиты конституционного строя в избирательном процессе представляет собой часть конституционного механизма защиты конституционного строя, при помощи которой осуществляется эффективное воздействие на общественные отношения, возникающие в связи с формированием органов публичной власти путем выборов, обеспечивается реализация конституционных прав участников избирательного процесса, защита демократических принципов и норм избирательного права, легитимация избирательного процесса.

Конституционно-правовой механизм защиты конституционного строя России в избирательном процессе включает в себя несколько подсистем: нормативную; институциональную; функционально-коммуникативную.

Защита конституционного строя России в избирательном процессе осуществляется уполномоченными государственными органами и учреждениями - субъектами защиты конституционного строя в избирательном процессе. Все эти 
субъекты выступают от имени государства и могут быть наделены правом издавать нормативные правовые и правоприменительные акты.

По объему компетенции можно выделить: субъекты общей компетенции, уполномоченные рассматривать не только вопросы организации избирательного процесса, но и вопросы защиты конституционного строя в условиях выборов (Президент Российской Федерации, Федеральное Собрание Российской Федерации, Правительство Российской Федерации, органы государственной власти субъектов Российской Федерации), а также субъекты специальной компетенции (органы федеральной службы безопасности, избирательные комиссии, суды, органы прокуратуры, налоговые органы, учреждения и филиалы Центрального банка Российской Федерации и Сбербанка России, органы юстиции, органы внутренних дел, органы Федеральной миграционной службы, органы Министерства по делам гражданской обороны, чрезвычайным ситуациям и ликвидации последствий стихийных бедствий, органы Министерства иностранных дел Российской Федерации, воинские формирования и органы Министерства обороны Российской Федерации), осуществляющие деятельность по специальному предмету ведения. В свою очередь, особенности правосубъектности позволяют выделить: субъекты, непосредственно осуществляющие защиту конституционного строя в избирательном процессе (высшие федеральные и региональные органы государственной власти, суды и органы федеральной службы безопасности), и субъекты, содействующие защите конституционного строя в избирательном процессе (избирательные комиссии, органы прокуратуры, налоговые органы, учреждения Центрального банка Российской Федерации и филиалы Сбербанка России, органы юстиции, органы внутренних дел, органы Министерства иностранных дел Российской Федерации, органы Министерства по делам гражданской обороны, чрезвычайным ситуациям и ликвидации последствий стихийных бедствий, воинские формирования и органы Министерства обороны Российской Федерации).

3. Основной объем работы по защите конституционного строя в избирательном процессе, а также реализация организационно-технических мероприятий, связанных с подготовкой и проведением избирательных кампаний, возложены на субъекты специальной компетенции. Нормативное правовое 
регулирование участия компетентных государственных органов и учреждений в защите конституционного строя в условиях выборов осуществляется на всех стадиях избирательного процесса. $\mathrm{B}$ рамках избирательных кампаний компетентные государственные органы и учреждения участвуют в решении задач по борьбе с попытками проникновения криминалитета, представителей экстремистских организаций, иностранных спецслужб в органы государственной власти и местного самоуправления, с незаконным финансированием избирательных кампаний, незаконной предвыборной агитацией, осуществляют противодействие распространению избирательных технологий манипулятивного воздействия на общественное сознание, попыткам фальсификации итогов голосования и результатов выборов. 


\section{ГЛава 3. ЗАРУБЕЖНЫЙ ОПЫТ НОРМАТИВНОГО ПРАВОВОГО ОБЕСПЕЧЕНИЯ ЗАЩИТЫ КОНСТИТУЦИОННОГО СТРОЯ В ИЗБИРАТЕЛЬНОМ ПРОЦЕССЕ}

\section{1. Международное правовое регулирование избирательного процесса}

Международные правовые акты, регламентирующие процедуры защиты конституционного строя в процессе выборов, являются результатом нормотворческой деятельности международных организаций (их органов) по вопросам избирательного права и избирательного процесса.

Актуальность изучения международного правового регулирования защиты конституционного строя в избирательном процессе обусловлена отсутствием общетеоретических и прикладных научных исследований в данной области, активизацией международной деятельности по наблюдению за выборами, а также недостатками национальной правовой базы, регламентирующей общественные отношения, связанные с защитой конституционного строя в условиях выборов. Необходимость комплексной разработки международных избирательных стандартов также подтверждается практикой российских и зарубежных избирательных кампаний, сопровождающихся массовыми беспорядками, террористическими акциями, отмыванием денежных средств, фальсификациями результатов выборов и иными угрозами конституционному строю.

Международное правовое регулирование представляет собой властное воздействие государств на межгосударственные отношения с помощью норм международного права. Международное правовое регулирование осуществляется путем определения стандартов, моделей обязательного, возможного и недопустимого поведения, а также побуждения субъектов следовать этим стандартам ${ }^{1}$. Данный вид регулирования направлен на выработку международных правовых обязательств участников межгосударственных отношений.

${ }^{1}$ См.: Лукашук И.И. Международное право. Общая часть. М.: Изд-во БЕК, 1997. С. 161. Более подробно процесс международного правового регулирования рассматривается в работе Лукашук И.И. Международноправовое регулирование международных отношений. М.: Международные отношения, 1975. 
Особенностями международного правового регулирования являются согласие участников правотворчества с нормативными предписаниями, формализованность, определенность содержания, относительная стабильность по сравнению с другими видами социального регулирования, возможность прогнозирования результатов правотворческой деятельности.

Главное преимущество международного правового регулирования заключается в том, что оно обеспечивает взаимодействие государств в правотворческом процессе и опирается на их поддержку. Источником международного регулирования служит суверенная власть государств-участников правотворчества.

Следует согласиться с И.И. Лукашуком в том, что «государственновластный момент в международном правовом регулировании имеет внутренний и международный аспекты» ${ }^{1}$. Внутренний аспект состоит в подчинении деятельности государственных органов, индивидов, организаций государственной воле, с тем, чтобы эта деятельность не противоречила задачам участия государства в системе международного правового регулирования. Международный аспект государственно-властного момента этого регулирования состоит в использовании каждым субъектом имеющихся у него государственновластных средств для сотрудничества с другими государствами в создании и осуществлении международных правовых норм, а в случае необходимости и для применения мер принуждения к правонарушителю.

Подсистема международного правового регулирования организации и проведения выборов является частью системы международного правового регулирования ${ }^{2}$.

Объектом международного правового регулирования организации и проведения выборов выступают межгосударственные отношения в области избирательного права и избирательного процесса.

\footnotetext{
${ }^{1}$ См.: Лукашук И.И. Международное право. Общая часть. М.: Изд-во БЕК, 1997. С. 164.

${ }^{2}$ См.: Миронов Н.М. Международные избирательные стандарты и развитие современного международного права // Международные юридические чтения. Материалы науч.-практ. конф. Омск: Изд-во Омск. юрид. ин-та, 2005. Ч.1. С. 183-186.
} 
Как отмечает В.И. Лысенко, «задачами международной деятельности по выработке норм - стандартов в электоральной сфере являются: создание надлежащих правовых эталонов регулирования отношений, складывающихся по поводу закрепления избирательных прав граждан и демократических избирательных процедур, а именно: устранение нерационального многообразия видов регулирования в области избирательного права на основе общепризнанных и других международных стандартов; создание механизмов, позволяющих доступно взаимно контролировать и «измерять» качество такого регулирования; создание и совершенствование методов воздействия на поведение участников отношений в данной сфере, т.е. гармонизация национального законодательства» ${ }^{1}$.

Размышляя о природе международных избирательных стандартов, Ю.А. Веденеев пишет: «Международные избирательные стандарты адресованы одновременно и государству, обязывая его обеспечить граждан адекватным природе демократического политического процесса объективным правом, и гражданам, предоставляя и гарантируя им определенные юридические возможности, т.е. субъективные политические права»² .

Исследование массива международных документов показывает, что международное правовое регулирование защиты конституционного строя в избирательном процессе представлено тремя основными фрагментами. Первый фрагмент составляют международные стандарты, закрепляющие основные требования к легитимности, справедливости, демократизму, подлинному и свободному характеру выборов. Второй фрагмент включает международные стандарты, закрепляющие государственный механизм защиты общепризнанных принципов и норм избирательного права, а также стандарты, регулирующие деятельность компетентных государственных органов и учреждений, обеспечивающих защиту конституционного строя в условиях избирательного процесса. Третий фрагмент содержит международные стандарты,

\footnotetext{
${ }^{1}$ См.: Международные избирательные стандарты. Сб. документов / Отв. ред.: доктор юрид. наук В.И. Лысенко. М.: ЦИК России, 2009. С. 23.

2 См.: Веденеев Ю.А. Развитие избирательной системы Российской Федерации: проблемы правовой институционализации // Журнал российского права. 2006. № 6. С. 56.
} 
устанавливающие общие требования к законотворческому процессу и качеству законодательства в сфере выборов.

Фундаментальное значение для обеспечения стабильности конституционного строя и безопасности государства имеют международные стандарты, закрепляющие основные требования к легитимности, справедливости, демократизму, подлинному и свободному характеру выборов ${ }^{1}$. Часть 3 статьи 21 Всеобщей декларации прав человека 1948 г. подчеркивает, что «воля народа должна находить себе выражение в периодических и нефальсифицированных выборах, которые должны проводиться при всеобщем и равном избирательном праве, путем тайного голосования или же посредством других равнозначных форм, обеспечивающих свободу голосования». Как отмечается в разделе I Руководящих принципов Венецианской комиссии Совета Европы относительно выборов 2002 г., «общеевропейскими принципами в области выборов являются всеобщее, равное, свободное, прямое и тайное избирательное право». Пункт «b» статьи 25 Международного Пакта о гражданских и политических правах 1966 г., статья 3 Протокола № 1 к Конвенции о защите прав человека и основных свобод 1952 г., параграф 6 Копенгагенского Документа СБСЕ 1990 г. предусматривают периодичность выборов.

Более детально защита конституционного строя в условиях избирательного процесса регламентируется международными стандартами, закрепляющими государственный механизм защиты общепризнанных принципов и норм избирательного права, а также стандартами, регулирующими деятельность компетентных государственных органов и учреждений, обеспечивающих защиту конституционного строя в ходе выборов. Ключевым элементом государственного механизма защиты конституционного строя в избирательном процессе являются конституционно-правовые ограничения организации и деятельности политических партий. Руководящие принципы запрета и роспуска политических

\footnotetext{
${ }^{1}$ См.: Вешняков А.А. Избирательные стандарты в международном праве и их реализация в законодательстве Российской Федерации. М.: Весь мир, 1997. 184 с; Вешняков А.А. ООН и международные избирательные стандарты: некоторые аспекты становления и развития // Журнал российского права. 2005. № 10. С. 3-15; Миронов H.M. Международные избирательные стандарты и российские выборы // Сравнительное конституционное обозрение. 2005. № 4. С. 66-77.
} 
партий Венецианской комиссии 1999 г. подчеркивают, что «запрет или роспуск политических партий может осуществляться только тогда, когда это необходимо в демократическом обществе, и когда имеются конкретные доказательства, что партия занимается деятельностью, угрожающей демократии и основополагающим свободам ... Партия, которая ставит целью мирное изменение конституционного строя путем использования законных средств, не может быть запрещена или распущена только изза того, что она свободно выражает свое мнение. Сам по себе вызов существующему строю не должен рассматриваться в демократическом государстве как подлежащее наказанию нарушение. Правовые меры, направленные на запрет или предписанный законом насильственный роспуск политических партий, должны быть результатом судебного решения о неконституционности этих партий, носить чрезвычайный характер и соответствовать принципу пропорциональности. Любая такая мера должна основываться на достаточных доказательствах того, что сама партия, а не только ее отдельные члены преследуют политические цели, используя или готовясь использовать неконституционные средства» ${ }^{1}$.

Помимо фиксации механизма защиты общепризнанных принципов и норм избирательного права анализируемый фрагмент международного правового регулирования определяет стандарты, регулирующие деятельность компетентных государственных органов и учреждений на конкретных стадиях выборов. Так, часть 4 статьи 6 Конвенции о стандартах демократических выборов, избирательных прав и свобод в государствах-участниках СНГ 2002 г. призывает компетентные государственные органы и учреждения не допускать действий и препятствовать распространению призывов, побуждающих или имеющих своей целью побуждение к срыву или отмене, или переносу срока выборов, избирательных действий и процедур, назначенных в соответствии с конституцией, законами․

\footnotetext{
${ }^{1}$ См.: Руководящие принципы запрета и роспуска политических партий Европейской комиссии «За демократию через право» (Венецианской комиссии) (Венеция, 10-11 декабря 1999 г.) // Совет Европы и Россия. 2001. № 1. С. $42-45$.

2 См.: Конвенция о стандартах демократических выборов, избирательных прав и свобод в государствахучастниках Содружества Независимых Государств: Документы и материалы /Отв. ред. доктор юридических наук, заслуженный юрист Российской Федерации В.И. Лысенко. М.: РЦОИТ, 2008. С. 103.
} 
C позиций защиты конституционного строя и гарантий всеобщего избирательного права важное значение имеет международное регулирование регистрации (учета) избирателей. Согласно Руководящим принципам Венецианской комиссии относительно выборов для достоверности списков избирателей важно обеспечить соблюдение следующих критериев: списки избирателей должны быть постоянными; они должны регулярно (не реже одного раза в год) обновляться; списки избирателей должны публиковаться; должна существовать административная процедура, подконтрольная судебным органам, либо судебная процедура, позволяющая зарегистрировать незарегистрированного избирателя; должна существовать аналогичная процедура, позволяющая избирателям вносить исправления в неправильные записи ${ }^{1}$

Руководящие принципы Венецианской комиссии Совета Европы относительно выборов фиксируют ряд требований к образованию избирательных округов и участков. При нарезке одномандатных округов допустимое отклонение от нормы не должно превышать 10\% и ни в коем случае не может превышать 15 \%, за исключением особых обстоятельств (например, защиты интересов компактно проживающего меньшинства).

Раздел IX Лундских рекомендаций по выборам ОБСЕ (Варшава, июнь 1999 г.) содержит положения, касающиеся формирования и деятельности избирательных органов: «Никакие посторонние лица, представители властей или политических партий не должны пытаться руководить деятельностью избирательного органа; он должен работать без каких-либо политических пристрастий или предпочтений».

Параграф 7.5 Копенгагенского Документа СБСЕ 1990 г. гарантирует соблюдение права граждан выдвигать свою кандидатуру на политические или государственные посты индивидуально или в качестве представителей политических партий и организаций без дискриминации. Кандидату может быть отказано в регистрации в случае, если: а) программа кандидата или партии основана на этнической ненависти, политическом насилии или пропаганде войны, или каким-

\footnotetext{
${ }^{1}$ См.: Международные избирательные стандарты. Сб. документов // Отв. ред. доктор юрид. наук В.И. Лысенко. М.: ЦИК России, 2009. С. 426.
} 
либо иным образом не соответствует основным демократическим ценностям; b) поведение кандидата демонстрирует неготовность уважать закон и ограничиваться мирными средствами для достижения своих целей ${ }^{1}$.

На стадии финансирования избирательной кампании законодательство должно предотвратить возможные злоупотребления государственными ресурсами, выделенными для целей избирательной кампании, и гарантировать, чтобы эти ресурсы использовались в строгом соответствии с применимыми юридическими положениями. В интересах защиты конституционного строя приемлемым является ограничение общего размера расходов на ведение избирательной кампании (статья 9 Рекомендации от 8 апреля 2003 г. № Rec (2003) 4 Комитета Министров Совета Европы «Об общих принципах борьбы с коррупцией при финансировании политических партий и избирательных кампаний»).

Международные избирательные стандарты предполагают, что избирательная кампания осуществляется в атмосфере, которая обеспечивает свободу самовыражения, собраний и ассоциаций. В агитационный период политическим партиям и кандидатам должен быть предоставлен одинаковый доступ к СМИ и гарантировано равное отношение со стороны СМИ, принадлежащих или контролируемых государством, в целях объективного и беспристрастного информирования избирателей (параграфы 7.6 и 7.8 Копенгагенского Документа СБСЕ 1990 г., пункты «б» и «в» части 9.2 Руководства по наблюдению за выборами БДИПЧ/ОБСЕ) ${ }^{2}$.

В пункте 9 части 3 Декларации о критериях свободных и справедливых выборов Межпарламентского Союза говорится о том, что ни один кандидат или политическая партия не должны использовать какие-либо формы насилия для агитации. В соответствии с частью 6 статьи 13 Конвенции о стандартах демократических выборов, избирательных прав и свобод в государствах-участниках СНГ «при проведении агитационной деятельности не допускается злоупотребление свободой слова и свободой массовой информации, в том числе призывы к

\footnotetext{
${ }^{1}$ Там же. С. 874.

${ }^{2}$ См.: Международные избирательные стандарты. Сб. документов // Отв. ред. доктор юрид. наук В.И. Лысенко. М.: ЦИК России, 2009. С. 229.
} 
насильственному захвату власти, насильственному изменению конституционного строя и нарушению территориальной целостности государства, призывы, направленные на пропаганду войны, террористических, любых иных насильственных действий и возбуждающие социальную, расовую, национальную, этническую, религиозную ненависть и вражду» ${ }^{1}$.

Раздел XII В Рекомендаций БДИПЧ/ОБСЕ по анализу законодательной базы выборов определяет, что процедуры голосования должны обеспечивать правильное установление личности избирателя, а также предусматривать наличие других механизмов для предотвращения фальсификаций или двойного голосования. Процедуры голосования должны обеспечивать должное хранение бюллетеней и избирательной документации до, во время и после голосования.

В пункте 3.2 раздела II Руководящих принципов Венецианской комиссии относительно выборов закреплены гарантии законности и безопасности при использовании альтернативных способов голосования (голосования по почте, электронного голосования, голосования по доверенности).

Международные документы возлагают на компетентные органы задачи по осуществлению мероприятий, связанных с недопущением подкупа участников выборов и незаконного вмешательства в деятельность избирательных комиссий при подсчете голосов и установлении результатов выборов. Согласно пунктам 6 и 8 части 4 Декларации о критериях свободных и справедливых выборов Межпарламентского Союза 1994 г. «государственные органы должны обеспечить такие условия, когда при голосовании исключается подкуп или другие противозаконные действия, сохраняются безопасность и целостность процесса голосования, а подсчет голосов проводится подготовленным персоналом и может быть подвергнут беспристрастной проверке»².

Нормативные правовые акты Совета Европы и ОБСЕ подчеркивают правомерность вмешательства в избирательный процесс правоохранительных

\footnotetext{
${ }^{1}$ См.: Конвенция о стандартах демократических выборов, избирательных прав и свобод в государствахучастниках Содружества Независимых Государств: Документы и материалы /Отв. ред. доктор юридических наук В.И. Лысенко. М.: РЦОИТ, 2008. С. 108.

${ }^{2}$ См. Декларация о критериях свободных и справедливых выборов (Париж, 26 марта 1994 г.) (По документам Межпарламентского Союза) М.: Известия, 1994. 11 с.
} 
органов и спецслужб для пресечения массовых беспорядков. Так, раздел 3.6 Руководящих принципов Венецианской комиссии Совета Европы относительно выборов устанавливает, что «все законы о выборах должны предусматривать вмешательство сил правопорядка в случае волнений».

Краеугольным камнем демократических выборов является точный и честный подсчет голосов. Параграф 7.4 Копенгагенского Документа СБСЕ 1990 г. требует, чтобы «подсчет голосов и сообщение о нем были честными, а официальные результаты были опубликованы».

Ключевой проблемой защиты конституционного строя является проблема сохранения наблюдаемым государством своей независимости в условиях агрессивного внешнего наблюдения за выборами. Поэтому международные избирательные стандарты допускают ограничения на вмешательство иностранных государств в избирательный процесс (статья 16 Конвенции о защите прав человека и основных свобод, часть 7 статьи 1 Конвенции о стандартах демократических выборов, избирательных прав и свобод в государствах-участниках СНГ, Декларация принципов международного наблюдения за выборами ООН).

Важное значение для защиты конституционного строя имеет государственный механизм защиты общепризнанных принципов и норм избирательного права. «Государства должны обеспечить меры для того, чтобы случаи нарушения прав человека и жалобы, относящиеся к избирательному процессу, рассматривались быстро и эффективно во временных рамках избирательного процесса такими независимыми и беспристрастными органами, как избирательные комиссии или суды» (пункт 9 части 3 Декларации о критериях свободных и справедливых выборов Межпарламентского Союза) ${ }^{1}$.

Третий фрагмент международного правового регулирования защиты конституционного строя в избирательном процессе представлен международными стандартами, устанавливающими общие требования к законотворческому процессу и качеству законодательства в сфере выборов.

\footnotetext{
${ }^{1}$ См.: Международные избирательные стандарты. Сб. документов // Отв. ред. доктор юрид. наук В.И. Лысенко. М.: ЦИК России, 2009. С. 816.
} 
Законодательная основа проведения выборов должна быть установлена либо посредством исчерпывающего кодекса, либо посредством пакета законодательных актов, работающих согласованно и не допускающих двусмысленности и пробелов. В подпунктах «а» и «b» части 2 раздела II Руководящих принципов Венецианской комиссии относительно выборов говорится о том, что стабильность избирательного законодательства имеет важнейшее значение для укрепления авторитета избирательного процесса.

Международные акты, регулирующие защиту конституционного строя в избирательном процессе, являются элементом национальных правовых систем и реализуются в законодательстве о выборах и политических партиях ${ }^{1}$. Имплементация международных избирательных стандартов в практику выборов позволяет обеспечивать легитимность формирования органов публичной власти, законность избирательного процесса, реализацию избирательных прав и свобод граждан ${ }^{2}$.

Выделим ряд проблем, связанных с трансформацией положений международных правовых актов в исследуемой области в российскую правовую систему ${ }^{3}$.

Первостепенное значение для защиты конституционного строя имеет проблема пределов ограничения суверенных электоральных прав Российской Федерации в пользу правовых предписаний международных нормативных документов. Представляется, что главную роль в экспертизе соответствия международных договоров Российской Федерации в сфере выборов Конституции России должны играть Министерство юстиции, Федеральное Собрание и Конституционный Суд Российской Федерации. Не соответствующие

\footnotetext{
1 См.: Каюров Е.A. Международные избирательные стандарты и их роль в развитии национальной избирательной системы // Проблемы гармонизации публичных и частных интересов в избирательном праве. Заметина T.B. Принципы российского избирательного права и международные избирательные стандарты: проблемы соотношения // Юридическая наука и образование. 2008. № 1. С. 117-123.

${ }^{2}$ См.: Вешняков А.А. Избирательные стандарты в международном праве и их реализация в законодательстве Российской Федерации. М.: Весь мир, 1997. 184 с; Фомин А.А. Международные избирательные стандарты и их реализация в законодательстве Российской Федерации // Представительная власть - ХХІ век: законодательство, комментарии, проблемы. 2004. № 4. С. 21-24; Хасанов У.Ф. Реализация международных избирательных стандартов в законодательстве субъекта Российской Федерации. Автореф. дис. ... канд. юрид. наук. Уфа, 2004. 27 с.

${ }^{3}$ См.: Шемелин А.B. Проблемы реализации международных избирательных стандартов и имплементации зарубежных избирательных моделей в России // История государства и права. 2009. № 20. С. 29-31.
} 
Конституции России международные договоры Российской Федерации не должны ратифицироваться и применяться.

Актуальной является проблема гармонизации зарубежной и национальной источниковой базы регулирования избирательного процесса. Согласно международным стандартам, правовые нормативы, обеспечивающие проведение выборов, не могут устанавливаться актами исполнительной власти. Между тем, в ряде государств СНГ (Азербайджан, Беларусь, Кыргызстан, Российская Федерация, Таджикистан) и Европы (Великобритания, Испания, Италия, Нидерланды) важное значение для регламентации избирательного процесса имеют подзаконные нормативные правовые акты, которые издаются на основе и во исполнение законов, являясь формой реализации компетенции субъектов правотворчества.

Нуждается в разработке и нормативная правовая база, касающаяся безопасности избирательного процесса и защиты конституционных прав российских граждан на избирательных участках, образованных за пределами территории Российской Федерации. Это обусловливает необходимость заключения соответствующих межгосударственных, межправительственных и межведомственных договоров с зарубежными государствами.

\section{2. Правовое обеспечение избирательного процесса в зарубежных странах в интересах защиты конституционного строя}

Как свидетельствует электоральная практика, проходящие в последние годы за рубежом избирательные кампании приобретают все более конфронтационный и политически острый характер. Некоторые из них напрямую затрагивают защищенность основ конституционного строя, стимулируют рост правонарушений и социально-политическую напряженность. Примером могут служить получившие широкий общественный резонанс факты проникновения криминалитета в органы государственной власти Италии и Болгарии, экстремистские выступления лидера Национального Фронта Франции Ле Пэна в ходе президентских выборов 2002 г., угроза целостности Украины в ходе 
президентских выборов в ноябре 2004 - январе 2005 гг., поддержка выдвижения отдельных кандидатов и наблюдение на выборах Президента Республики Кыргызстан 2005 г. со стороны экстремистской партии «Хизб-ут-Тахрир альИслами», фальсификация результатов парламентских выборов в Таиланде в декабре 2007 г., повлекшая роспуск правящей «Партии народной власти» и запрет ее руководству заниматься политической деятельностью в течение пяти лет, массовые беспорядки в Улан-Баторе после проведения парламентских выборов в июне 2008 г., массовые беспорядки в Кишиневе в связи с парламентскими выборами в Молдавии в апреле 2009 г., политический кризис в Иране после объявления результатов президентских выборов 2009 г. В этой связи весьма актуальным становится вопрос защиты конституционного строя в условиях избирательного процесса.

На этапе составления списков избирателей, а также при выдвижении и регистрации кандидатов на выборные должности в зарубежных странах в интересах защиты конституционного строя активно используется ограничение и лишение избирательного права отдельных категорий граждан ${ }^{1}$. В теории избирательного права и конституционно-правовой практике следует различать «ограничение избирательного права» как законодательные требования к избирательному корпусу и кандидатам и «лишение избирательного права» как меру предупреждения девиантного поведения граждан или меру наказания, применяемую к правонарушителям.

Сущность ограничения избирательного права заключается в законодательном сужении правовых возможностей субъекта права реализовать принадлежащие ему субъективные избирательные права. Данное ограничение правосубъектности носит устранимый характер. Для вступления субъекта права в правоотношения, связанные с выборами органов публичной власти, требуется возникновение определенного фактического состава или юридического факта -

\footnotetext{
${ }^{1}$ См.: Игнатов А.В. Ограничения всеобщего избирательного права в отношении права быть избранным в национальные парламенты государств-участников СНГ / Научные труды РАЮН. Вып. 9. Т.1. М.: Юрист, 2009. С. 965-969; Куракина С.И, Цьљисова А.С. Ограничения в избирательном праве: международная практика / IV Державинские чтения в Республике Мордовия. Материалы науч.-практ. конф. Саранск, 2008. С. 199-200; Сафаров P.A. Проблема неправомерного ограничения избирательных прав граждан в зарубежных странах / Проблемы защиты прав: история и современность. Материалы Международной науч.-практ. конф. СПб, 2007. С. 88-93.
} 
достижение определенного возраста, пребывание на территории государства в течение установленного законом периода времени, увольнение с гражданской или военной службы, оставление сана и т.д. Ограничение активного избирательного права направлено на образование избирательного корпуса, способного по своим качественным характеристикам самостоятельно, осознанно и ответственно формировать органы народного представительства. Целями ограничения пассивного избирательного права являются: обеспечение политической независимости представителей обозначенных в законе государственных органов, защита прав избирателей, ограничение возможностей кандидатов использовать служебное положение (административный ресурс) в условиях выборов.

Лишение избирательного права заключается во временной или бессрочной утрате субъектом права субъективного избирательного права, являющейся мерой превентивного или карательного характера. Лишение избирательного права может быть связано как с правомерным (недееспособность), так и с противоправным поведением субъектов права. Лишение избирательного права кроме ограничения правосубъектности недееспособных лиц означает основное или дополнительное уголовное наказание, которое закреплено в санкции нормы права, носит личный характер и назначается судом с учетом общественной опасности правонарушения. Во многих зарубежных странах лица, отбывающие наказание в местах лишения свободы по приговору суда ограничены в избирательном праве или лишены егоํㅡ. В Австрии, Бельгии, Франции, Германии, Греции, Италии, Люксембурге, Мальте, Нидерландах, Норвегии, Польше, Румынии и Турции существуют ограничения избирательного права заключенных. В Армении, Азербайджане, Болгарии, Эстонии, Грузии, Ирландии, Латвии, Лихтенштейне, Молдавии, Российской Федерации, Словакии и Великобритании заключенные лишены права голоса.

1 См.: Дуксин П.А. Лишение избирательных прав лиц, признанных судом недееспособными, и лиц, содержащихся в местах лишения свободы по приговору суда: справедливость и целесообразность / Сборник конкурсных работ в области избирательного права, избирательного процесса и законодательства о референдуме, выполненных студентами и аспирантами высших юридических учебных заведений Российской Федерации в $2004-$ 2005 году. М.: РЦОИТ, 2005. С. 125-138. 
Целями лишения избирательного права являются: поддержание авторитета закона, исключение возможности криминального влияния на формирование органов народного представительства, недопущение правонарушителей в выборные органы власти. В отличие от ограничения избирательного права, лишение избирательного права в зарубежных странах может носить как устранимый (истечение срока наказания, помилование, амнистия), так и неустранимый характер (пожизненное тюремное заключение с бессрочным лишением, недееспособность вследствие неизлечимого психического заболевания). Конкретные основания, сфера и продолжительность действия, механизм реализации лишения избирательного права устанавливаются конституционным, выборным и уголовным законодательством.

По времени действия различают пожизненное лишение избирательного права и лишение избирательного права на определенный срок. Согласно статьям L 5-8 Избирательного кодекса Франции лица, осужденные за преступления, лишаются избирательных прав пожизненно. В отношении осужденных за проступки в сфере избирательного права лишение избирательного права может носить временный характер ${ }^{1}$.

В соответствии с $§ 45$ УК ФРГ лишение пассивного избирательного права осуществляется на срок от 2 до 5 лет. § 22 разд. 2 Положения о порядке проведения выборов в Национальный Совет Австрии (Nationalratswahlordnung 1992) предусматривает лишение осужденных избирательного права на 6 месяцев ${ }^{2}$. В Китае политических (в том числе и избирательных) прав пожизненно лишаются лица, совершившие контрреволюционные преступления, а также осужденные к смертной казни и бессрочному лишению свободы ${ }^{3}$.

По сфере действия лишение избирательного права может распространяться на выборы в конкретном избирательном округе (локальное лишение) или на все виды выборов на всей территории государства (универсальное лишение права).

\footnotetext{
${ }^{1}$ См. Избирательный кодекс Франции // Journal Officiel de la Republique Franзaise, 26 janvier 1985. № 21.

${ }^{2}$ CM. Bundesgesetz BGBl. Nr. 47/ 1992; BGB1. I Nr. 28/2007.

${ }^{3}$ См. Зарубежное избирательное право: Учебное пособие. М.: Норма, 2003. С. 168.
} 
Лицо, совершившее коррупционное правонарушение в сфере избирательного права Великобритании (мошенничество, неправомерное давление на избирателей, превышение предельных размеров предвыборных расходов, подкуп, фальсификацию документов о выдвижении кандидата), лишается пассивного избирательного права на 10 лет на территории всей страны. За осуществление незаконной практики (нарушение различных законодательных требований о доверенных лицах, использования помещений, рекламы, освещения предвыборной кампании, голосование более одного раза, голосование, несмотря на лишение права голоса и др.) к правонарушителю применяется лишение пассивного избирательного права на 5 лет на территории конкретного избирательного округа ${ }^{1}$.

По содержанию изъятий объема правосубъектности лишение избирательного права делится на лишение активного избирательного права и лишение пассивного избирательного права. Решением Государственного трибунала Польской Республики лицо, совершившее преступление, связанное с нарушением Конституции или законов, может быть лишено как активного, так и пассивного избирательного права на всех видах выборов (п.1 ст. 23 Закона «О государственном трибунале» от 26 марта 1982 г.) $)^{2}$. В Канаде пассивного избирательного права лишены лица, отбывающие наказание в местах лишения свободы на срок свыше двух лет ${ }^{3}$.

По свободе усмотрения правоприменителя необходимо различать императивное и дискреционное лишение избирательного права. В случае императивного лишения избирательного права все основания лишения субъективного права четко предусмотрены действующим законодательством, и

\footnotetext{
${ }^{1}$ В соответствии с Актом о народном представительстве 1983 г. (the Representation of the People Act 1983) в избирательном праве Великобритании все правонарушения подразделяются на 2 вида - на коррупцию и незаконную практику (corrupt or illegal practices), что влечет для правонарушителя ограничение пассивного избирательного права. Аналогичная классификация правонарушений в сфере избирательного права принята и в Канаде. См. Зарубежное избирательное право: Учебное пособие. М.: Норма, 2003. С. 86.

${ }^{2}$ См. Современные избирательные системы. Вып. 1: Великобритания, Канада, Мексика, Польша. М.: Норма, 2006. C. 370 .

${ }^{3}$ См. Там же. С. 207.
} 
правоприменитель обязан ими руководствоваться (Мексика) ${ }^{1}$. Дискреционное лишение избирательного права осуществляется по усмотрению суда с учетом общественной опасности правонарушения, личности правонарушителя и других юридически значимых обстоятельств (Франция) ${ }^{2}$.

К числу особых видов лишения избирательного права в зарубежных странах можно отнести: приостановление избирательного права (Мексика); запрет регистрации в качестве кандидата от определенной политической партии (Мексика); объявление неизбираемости на определенный срок (Франция). Особые виды лишения избирательного права имеют ряд общих черт, определяющих их правовую природу: устранимость (субъект права сохраняет возможность восстановления избирательного права), превентивный или карательный характер (карательные элементы лишения права направлены на прекращение субъектом права антиобщественного или противоправного поведения).

Современная штрафная политика большинства зарубежных стран сочетает ориентацию на предупреждение девиантного и противоправного поведения граждан; экономию репрессивных мер, применяемых к правонарушителям, подвергнутым лишению избирательного права; рациональное дополнение различных видов наказаний, учитывающее степень общественной опасности допущенных нарушений закона.

В условиях избирательного процесса в зарубежных странах исключительно важное значение приобретает проблема нарезки избирательных округов 3 . Манипуляции в ходе нарезки избирательных округов, связанные с использованием «избирательной географии» или «избирательной геометрии», могут повлечь за собой искажение волеизъявления избирателей и достижение правящими силами необходимого результата на выборах. Не случайно в зарубежной избирательной практике нарезке округов уделяется самое

\footnotetext{
${ }^{1}$ См. Современные избирательные системы. Вып. 1: Великобритания, Канада, Мексика, Польша. М.: Норма, 2006. C. 292.

${ }^{2}$ См. Зарубежное избирательное право: Учебное пособие. М.: Норма, 2003. С. 93.

${ }^{3}$ Нормативное правовое регулирование образования избирательных округов в Российской Федерации рассматривается в параграфе 1.3 .
} 
пристальное внимание. Математическое неравенство численности избирателей при образовании избирательных округов остается повсеместной проблемой, но не рассматривается как несправедливость. Избирательные законы предусматривают преемлемую степень отклонения округов от равенства по численности избирателей, например 5\% в Хорватии или 10\% в Великобритании.

Согласно Акту о парламентских избирательных округах 1986 г. (Parlamentary Constituencies Act) в Великобритании изменением границ избирательных округов занимаются постоянные комиссии (Boundary Commissions), которые один раз в 10 лет представляют министру внутренних дел доклады с рекомендациями о числе и границах избирательных округов ${ }^{1}$. Итоговый документ принимается Парламентом в виде закона.

В Германии установлением границ избирательных округов занимается Постоянная комиссия, назначаемая Президентом ФРГ. Она анализирует изменение численности населения и вносит предложения о соответствующей нарезке округов. Доклад Постоянной комиссии о делении территории на избирательные округа направляется Министру внутренних дел ФРГ с последующей передачей в Бундестаг.

В США изменение границ избирательных округов осуществляется 1 раз в 10 лет по итогам переписи населения. В Португалии границы избирательных округов определяются избирательным законом, принимаемым перед каждыми новыми выборами².

В целях обеспечения контроля за законностью в деятельности избирательных органов во многих странах применяется наблюдение за выборами. Так, в Мексике в год проведения выборов при Федеральном избирательном институте создается Национальная комиссия по наблюдению за выборами и Национальный комитет по проверке результатов голосования. Такие же органы формируются на всех избирательных уровнях. В США в каждой участковой

\footnotetext{
${ }^{1}$ В соответствии с Актом о политических партиях, выборах и референдумах 2000 г. эта функция возложена на комитеты по пересмотру избирательных округов в Англии, Шотландии, Уэльсе и Северной Ирландии.

${ }^{2}$ См.: Избирательное право / Под ред. К.К. Гасанова, А.С. Прудникова. М.: Юнити-Дана: Закон и право, 2007. C. 278 .
} 
(Республиканской и Демократической). Они обычно именуются «избирательными судьями», поскольку конкурирующие партии внимательно следят за тем, чтобы для других сторон не было создано никаких незаконных преимуществ. В Канаде и Великобритании наблюдатели от кандидатов присутствуют в помещении, где с соблюдением мер охраны и безопасности происходит подсчет голосов, и следят за ходом этого подсчета ${ }^{1}$. Присутствие наблюдателей особенно оправданно при опротестовании результатов выборов и необходимости пересчета голосов².

Международный и зарубежный опыт избирательных кампаний, как правило, допускает возможность мониторинговых процедур по внешнему наблюдению за выборами.

В процессе развития иностранного (международного) наблюдения за выборами сформировалось несколько точек зрения, связанных с отношением различных государств к осуществлению иностранного (международного) наблюдения за выборами ${ }^{3}$. Первая точка зрения предполагает отрицательное отношение государства к внешнему наблюдению в связи с отсутствием четких критериев, позволяющих разграничить мониторинг за выборами и вмешательство во внутренние дела государства. Такой позиции придерживаются КНР, Индия, Куба.

Вторая точка зрения основана на отказе от внешнего мониторинга выборов в формате «наблюдательных» миссий, поскольку приглашение иностранных и международных наблюдателей предполагает добровольное признание государством своей конституционно-правовой и демократической незрелости, ориентацию на одобрение результатов народного волеизъявления со стороны иностранных государств (политических блоков государств) и ожидание легитимации избранной государственной власти извне. Альтернативой внешнему

\footnotetext{
${ }^{1}$ См.: Сравнительное избирательное право. М.: Норма, 2003. С. 65-66.

${ }^{2}$ См.: Зарубежное избирательное право. М.: Норма, 2003. С. 62

${ }^{3}$ Осуществление наблюдения за выборами со стороны иностранных государств позволяет вести речь об иностранном наблюдении, а мониторинг избирательной кампании, осуществляемый международными организациями, принято называть международным наблюдением за выборами.
} 
наблюдению за выборами признается развитая система национального общественного контроля за выборами или т.н. «экспертные встречи».

Сторонниками подобного подхода являются государства с давно сложившимися демократическими традициями, играющие ведущую роль в международных отношениях либо претендующие на статус влиятельных региональных держав. $\mathrm{K}$ их числу относятся: Австрия, Германия, Великобритания, Италия, Испания, Польша, США, Швейцария и Япония. В указанных государствах отсутствует законодательство, регулирующее мониторинговые процедуры на выборах, определяющее порядок аккредитации иностранных и международных наблюдателей, их права и обязанности. Поэтому присутствие иностранных и международных наблюдателей на избирательных участках не допускается. Приглашенные на выборы лица рассматриваются в качестве «гостей» избирательных органов. Данная группа государств оставляет за собой право отказаться от «наблюдательных» миссий и самостоятельно определяет количество наблюдателей в составе «оценочных» миссий.

Наконец, третья точка зрения основана на необходимости и практической пользе иностранного (международного) наблюдения за выборами. Она распространена в государствах, нуждающихся в оказании помощи при проведении избирательных кампаний - африканских, латиноамериканских странах, a также законодательно закреплена в некоторых государствах участниках СНГ.

Участие наблюдателей иностранных государств и международных организаций, представителей иностранных средств массовой информации на выборах является одним из условий обеспечения открытости и гласности избирательного процесса, реализации избирательных прав и свобод граждан, выполнения международных стандартов в области демократических выборов. Наблюдение за выборами может способствовать законности и демократичности избирательного процесса в любой стране, если это наблюдение носит нейтральный характер и осуществляется на основе единых требований для всех государств. К сожалению, следует констатировать, что современная модель 
международного наблюдения за выборами, реализуемая БДИПЧ ОБСЕ, не отвечает данным требованиям.

Отсутствие единой методологии мониторинга выборов и оценки их результатов приводит к тому, что в последние годы институт иностранного (международного) наблюдения утрачивает свой позитивный потенциал. Вместо содействия развитию демократии и гражданского общества он постепенно перерождается в удобный инструмент выполнения политического заказа и обслуживания геополитических интересов ведущих мировых держав (прежде всего США).

В связи с регулированием выборов в зарубежных странах особое внимание законодателя обращено на избирательные органы, организующие и проводящие выборы. В отношении подбора кадров, обеспечивающих проведение выборов, действует правило, что на эти должности не могут назначаться представители действующей власти - министры, сенаторы, депутаты, прокуроры, члены парламента предыдущего созыва, а также лица, исключенные из списков избирателей или утратившие избирательное право. В Канаде членами избирательных органов запрещено назначать лиц, которые в течение семи предшествующих лет были признаны виновными в совершении деяний, рассматриваемых как противозаконные по законодательству о выборах ${ }^{1}$. Избирательные органы осуществляют надзор за соблюдением избирательного законодательства, регистрируют списки кандидатов, проводят голосование, определяют результаты выборов и обнародуют их, рассматривают жалобы на действия нижестоящих избирательных органов.

Подробно регламентируется деятельность участников избирательного процесса по сбору подписей в поддержку выдвижения кандидатов (списков кандидатов). Так, по законодательству Польши сбор подписей в поддержку

\footnotetext{
${ }^{1}$ См. Современные избирательные системы. Вып. 1: Великобритания, Канада, Мексика, Польша. М.: Норма, 2006. C. 185 .
} 
кандидата может проходить только в местах, во время и способом, исключающим угрозы, подкуп либо применение какого-либо давления ${ }^{1}$.

Количество подписей, необходимых для выдвижения, зависит от уровня выборов и самой выборной должности. Например, для поддержки выдвижения кандидата на пост Президента Польской Республики требуется 100 тысяч подписей, для выдвижения кандидатов в депутаты Бундестага ФРГ от избирателей (групп избирателей) необходимо собрать 200 подписей избирателей соответствующего округа, при выборах в Риксдаг Швеции - 1500 подписей, при выборах в собрания ландстингов - 100 подписей, при выборах в собрания коммун - 50 подписей избирателей.

C позиций защиты конституционного строя серьезного внимания в зарубежных странах заслуживает стадия предвыборной агитации. Законодательные меры направлены, главным образом, на предупреждение зарубежного вмешательства в избирательный процесс, экстремистской деятельности и противодействие использованию кандидатами в депутаты и на выборные должности «административного ресурса».

По общему правилу в большинстве государств существует запрет на использование передач иностранных телевизионных кампаний в целях предвыборной агитации, за исключением случаев их ретрансляции национальными телеканаламиㄹ. Норма статьи 13 главы 19 Уголовного Уложения Швеции запрещает финансируемую иностранным государством, организацией или гражданином пропаганду, целью которой является оказание влияния на свободное формирование общественного мнения по политическим вопросам ${ }^{3}$. Политическим партиям Мексики запрещено обращаться и получать в любом виде экономическую, политическую или пропагандистскую помощь, предоставляемую иностранцами ${ }^{4}$.

\footnotetext{
${ }^{1}$ См. Современные избирательные системы. Вып. 1: Великобритания, Канада, Мексика, Польша. М.: Норма, 2006. C. 394.

${ }^{2}$ См.: Зарубежное избирательное право. М.: Норма, 2003. С. 85.

${ }^{3}$ См. Современные избирательные системы. Вып. 2: Аргентина, Германия, Швеция. М.: РЦОИТ: Норма, 2007. C. 240.

${ }^{4}$ См. Современные избирательные системы. Вып. 1: Великобритания, Канада, Мексика, Польша. М.: Норма, 2006. C. 298.
} 
Важное значение в условиях выборов имеет предупреждение экстремизма. Законодательство зарубежных стран запрещает создание и деятельность экстремистских организаций ${ }^{1}$.

Статья 13 Конституции Польской Республики закрепляет: «Запрещается существование политических партий и иных организаций, обращающихся в своих программах к тоталитарным методам и практике деятельности нацизма, фашизма и коммунизма, а также тех, программа или деятельность которых предполагает или допускает расовую и национальную ненависть, применение насилия с целью захвата власти или влияния на политику государства либо предусматривает сокрытие в тайне их структур или членства»².

В соответствии с Законом Аргентины «О политических партиях» в названиях политических партий запрещено использовать такие наименования, которые могут нанести вред международным отношениям государства, вызвать религиозный, расовый или классовый антагонизм. Избирательное законодательство Мексики содержит обязанность партий осуществлять свою деятельность мирными средствами и демократическим способом, воздерживаться от применения насилия и любых других актов, которые имеют целью или результатом нарушение общественного порядка, создание помех для реализации гарантий и нормального функционирования государственных органов 3 .

В ряде случаев в интересах защиты конституционного строя принимаются специальные законы или судебные решения о запрете конкретных политических партий и общественных организаций экстремистской направленности. Например, в Австрии принят закон «О запрете национал-социалистической рабочей партии Германии», в Италии - «О запрете неофашистской деятельности», в Португалии «О запрете фашистских организаций». В Алжире, Германии, Иордании, Ираке,

1 Как отмечается в пункте 6 Резолюции ПАСЕ 1344 (2003) «Об угрозе для демократии со стороны экстремистских партий и движений в Европе», «экстремистские партии и движения зачастую представляют собой олигархические структуры с четкой иерархией, которым чужды демократические принципы. Групповая сплоченность подкрепляется идеологией исключительности, популистскими, упрощенческими представлениями и единоличным принципом руководства».

${ }^{2}$ См. Современные избирательные системы. Вып. 1: Великобритания, Канада, Мексика, Польша. М.: Норма, 2006. C. 352.

${ }_{3}^{3}$ См. Современные избирательные системы. Вып. 1: Великобритания, Канада, Мексика, Польша. М.: Норма, 2006. C. 298, 303. 
Иране, Йемене, Казахстане, Кыргызстане, Пакистане, России, Судане, Таджикистане запрещена деятельность экстремистской религиозно-политической партии «Хизб-ут-Тахрир аль-Ислами».

Исключение составляет Великобритания, где любая партия, выдвинувшая не менее 50 кандидатов с внесением соответствующих залогов (по 500 фунтов стерлингов на кандидата) приобретает право на бесплатную политическую рекламу и может свободно пропагандировать свою идеологию и программные взгляды, в том числе экстремистского содержания.

В некоторых государствах установлены ограничения на работу государственных органов с кандидатами для того, чтобы обеспечить беспристрастность и равное отношение со стороны государства ко всем претендентам на депутатский мандат или выборную должность. Законодательство предусматривает специальные меры, направленные на то, чтобы воспрепятствовать использованию служебного положения для получения какихлибо преимуществ в ходе предвыборной кампании ${ }^{1}$.

Особо регулируется порядок использования политическими партиями средств массовой информации в период выборов. В некоторых странах политические партии имеют равные возможности в использовании СМИ, в других - законодательство предоставляет определенные преимущества партиям, имеющим парламентские фракции (например, в Австрии, Италии, Швеции право на бесплатное выступление на радио и телевидении имеют только политические партии, представленные в парламенте) $)^{2}$. Во многих государствах правящие власти используют свой контроль над государственными СМИ для пропаганды официальных взглядов и благоприятного освещения деятельности политического руководства.

С учетом решающей роли финансов в организации и проведении выборов законодательство зарубежных стран, как правило, устанавливает прозрачный механизм формирования и использования финансовых средств на выборные цели,

\footnotetext{
${ }^{1}$ См.: Сравнительное избирательное право. М.: Норма, 2003. С. 82.

${ }^{2}$ Там же. С. 93.
} 
a также подробно регулирует избирательные расходы. Наличие норм, регулирующих финансирование избирательных кампаний, крайне важно для борьбы с партийной коррупцией, легализацией денежных средств в условиях выборов, обеспечения целевого характера финансирования и публичной отчетности. Например, в Бельгии принят Закон «Об ограничении и контроле избирательных расходов» 1989 г., во Франции - Органический закон «О финансовой гласности политической жизни» 1988 г. и Закон «О финансировании избирательных кампаний» 1990 г., в Португалии - Закон «О финансировании политических партий и избирательных кампаний» 2003 г. В законодательных актах подробно регламентируется деятельность по созданию и расходованию избирательных фондов, определяются допустимые финансовые источники, закрепляются лимиты на финансирование и размеры избирательных расходов.

В большинстве государств мира запрещаются анонимные пожертвования на выборные цели, за исключением сбора средств на митингах или в общественных местах.

В Германии и Швеции существует процедура идентификации лиц, осуществляющих добровольные пожертвования в фонды политических партий, если на счет партии в течение года поступает сумма свыше 20 тысяч евро (шведских крон). Жертвователь обязан указать свое имя и адрес. В Канаде таким образом учитываются все пожертвования на сумму свыше 200 долларов. Если у финансовых уполномоченных возникнут сомнения в отношении источников финансирования, они обязаны в течение 30 дней с момента получения таких средств вернуть пожертвования.

Законодательство большинства государств признает политические партии основным участником избирательного процесса. В связи с этим государство частично финансирует избирательные кампании политических партий (Аргентина, Германия, Канада, Польша, США). Как правило, основными критериями распределения государственных субсидий между политическими партиями служат количество завоеванных мандатов, число выдвинутых 
кандидатов, число полученных партией голосов избирателей ${ }^{1}$. В некоторых зарубежных странах определена максимальная сумма финансирования всех политических партий (Швеция) ${ }^{2}$.

За финансовой деятельностью политических партий осуществляется строгий контроль. В партийной структуре должен функционировать орган, ответственный за управление имуществом партии и ее финансовыми средствами.

Партии обязаны ежегодно публиковать финансовые отчеты о своей деятельности. В Великобритании во время выборов политические партии обязаны представлять еженедельные отчеты обо всех пожертвованиях свыше 5000 фунтов. По общему правилу партиям запрещено принимать или получать взносы или пожертвования от государственных органов или учреждений иностранных государств, иностранных физических или юридических лиц, международных организаций, религиозных организаций, сект, представителей культа, государственных органов и учреждений, муниципалитетов.

Наиболее ответственным этапом избирательного процесса в зарубежных странах выступает организация голосования и определение результатов выборов.

В день голосования не допускается предвыборная агитация и проведение пропагандистских мероприятий ${ }^{3}$.

Голосование осуществляется на избирательных участках, оборудованных с учетом необходимости обеспечения тайны голосования. К голосованию допускаются лица, предъявившие документы, удостоверяющие личность. В Литве и Румынии используются специальные удостоверения избирателей. В Мексике удостоверение избирателя имеет фотографию, личную подпись, отпечатки пальцев и несколько степеней защиты от подделки. В США для удостоверения личности достаточно карточки социального страхования или водительского удостоверения.

\footnotetext{
${ }^{1}$ См.: Сравнительное избирательное право. М.: Норма, 2003. С. 92.

${ }^{2}$ См.: Касаткина Н.М. Финансирование выборов в зарубежных государствах // Журнал российского права. 2009. № 5. C. 106-119.

3 Запрет на агитацию не действует в Бельгии и Великобритании.
} 
В ряде случаев законодатель предусматривает процедуру защиты избирательных бюллетеней от возможных фальсификаций и недопущения голосования на другом участке. Так, в Канаде избирательные бюллетени на участках для голосования нумеруются ответственным лицом в присутствии кандидатов и их представителей. Цифры, нанесенные черными чернилами или специальным карандашом, проявляются, когда бюллетень опускается в урну для голосования. Этот метод применяется для защиты от использования фальшивых бюллетеней. В Мексике избирателям помечают большой палец правой руки несмываемой краской. Отметка на пальце не позволяет проголосовать в другом месте.

В целях обеспечения безопасности избирателей, кандидатов, представителей политических партий и членов избирательных органов запрещается вход с оружием в помещение избирательного участка. В день голосования могут закрываться учреждения и магазины, распространяющие алкогольные напитки (Мексика, Аргентина).

В некоторых зарубежных странах, где существуют противоречия между национальными, этническими и конфессиональными группами населения, в интересах защиты конституционного строя используется так называемая «фиджийская» система, которую называют системой выборов по налагающимся округам. Данная система выборов учитывает наличие в одном и том же избирательном округе нескольких электоральных групп. Например, на границе Индии и Пакистана есть избиратели, проповедующие индуизм, и избирателимусульмане. Законодатель стремится развести во времени голосования эти электоральные группы и тем самым избежать их открытого противостояния во время выборов ${ }^{1}$.

Определение результатов выборов во многом зависит от избирательной системы, принятой в том или ином государстве. Наиболее распространенными являются мажоритарная и пропорциональная избирательные системы.

\footnotetext{
${ }^{1}$ См.: Избирательное право / Под ред. К.К. Гасанова, А.С. Прудникова. М.: Юнити-Дана: Закон и право, 2007. C. 171.
} 
При мажоритарной избирательной системе избранным считается тот кандидат, избирательное объединение или политическая партия, кто получит большинство голосов избирателей ${ }^{1}$.

Пропорциональная избирательная система предполагает, что каждая партия или избирательное объединение получает такое количество мест в представительном органе, которое будет пропорционально количеству собранных партией или избирательным объединением голосов избирателей.

В государствах, где применяется пропорциональная избирательная система (Болгария, Дания, Польша, Турция, Швеция, Мексика, Израиль, Аргентина и др.) решающее значение для участников выборов приобретает заградительный барьер. Как отмечает С.А. Авакьян, заградительный пункт придумали в странах, которые: «а) не хотели пускать в парламент национал-социалистов, национал-радикалов и коммунистов; б) были заинтересованы в создании вместо множества безликих мелких политических партий и движений, крупных, даже мощных объединений, конкурирующих друг с другом и способных представить населению свои более или менее оригинальные платформы» ${ }^{2}$. Заградительные барьеры не только лишают политические партии мандатов в представительные органы власти, но и игнорируют волеизъявление значительного числа избирателей, проголосовавших за эти партии. В некоторых зарубежных странах заградительный барьер вообще отсутствует, например, в Австрии или Швейцарии. В Конституции Португалии содержится специальное положение, которое запрещает вводить подобные ограничения.

Известный французский конституционалист М. Дюверже проанализировал практику применения избирательных систем различных стран и выявил следующую закономерность: «мажоритарное голосование в один тур ведет к дуалистической системе с чередованием у власти больших независимых партий, а режим пропорционального представительства ведет к многопартийной системе» ${ }^{3}$.

\footnotetext{
${ }^{1}$ Существует три разновидности мажоритарной системы: мажоритарная система абсолютного большинства («французская модель»), мажоритарная система относительного большинства («английская модель») и мажоритарная система квалифицированного большинства. Подробней см. Избирательное право и избирательный процесс в Российской Федерации. М.: Норма, 1999. С. 104-108; Сравнительное избирательное право. М.: Норма, 2003. С. 133-139; Зарубежное избирательное право. М.: Норма, 2003. С. 20-24; Скосаренко Е.Е. Избирательная система России: мифы и политическая реальность. М.: Формула права, 2007.

${ }^{2}$ См.: Авакьян C.A. Небескорыстная инициатива. Все аргументы ее авторов рождены заботой о собственном благе // Независимая газета. 1995. 15 ноября.

${ }^{3}$ См.: Дюверже М. Политические партии. М., 2002. С. 265.
} 
В некоторых государствах используется сочетание элементов мажоритарной и пропорциональной избирательных систем (ФРГ, Италия, Мексика, Венгрия).

В ряде государств, в которых проживают национальные меньшинства, в целях недопущения сепаратизма и экстремизма используются т.н. «особые» избирательные системы. Особые избирательные системы призваны, с одной стороны, обеспечить представительство меньшинств (этнических, национальных, конфессиональных, административно-территориальных, автономных и т.д.) в выборном органе, с другой - нейтрализовать социально-политическую напряженность, которую могут вызвать выборы в отдельных нестабильных регионах. Один из типов особых систем принято называть «ливанским». Речь идет о системе многомандатных округов, где за меньшинством закрепляется определенное количество мандатов еще до выборов ${ }^{1}$.

Дополнительной гарантией реализации избирательных прав граждан в зарубежных странах при осуществлении голосования выступает возможность голосования по почте. Почтовое голосование активно используется на выборах в США, Великобритании, Австралии, Новой Зеландии, Канаде, Австрии, Бельгии, Германии, Дании, Ирландии, Исландии, Испании, Италии, Франции, Швеции, Швейцарии ${ }^{2}$.

Анализ зарубежного опыта почтового голосования на выборах позволяет выделить основные проблемы безопасности голосования, возникающие при реализации гражданами данного способа волеизъявления:

- отсутствие гарантий от утраты конвертов с бюллетенямиㅜ;

- прямая зависимость легитимности выборов от качества составления и обновления списков избирателей;

- возможность противоправного использования избирательных процедур при проведении почтового голосования ${ }^{1}$;

\footnotetext{
${ }^{1}$ См.: Конституционное право России / Под ред. А.С. Прудникова, В.И. Авсеенко. М., 2007. С. 449.

2 См.: Граф И.В., Жаромских Д.Г. Опыт применения голосования по почте при проведении выборов в зарубежных странах / Особенности реализации избирательного законодательства на современном этапе. Материалы Всерос. науч.-практ. конф. Тюмень, 2008. С. 151-157; Забайкалов А.П. Некоторые аспекты применения голосования по почте на выборах в зарубежных странах // Общество и право. № 4. Краснодар, 2008. С. 129-134.

${ }^{3}$ См. Times online. 06.05.05. 20000 missing votes heighten Birmingham postal fraud fears.
} 
- зависимость почтового голосования от соблюдения сроков доставки корреспонденции адресатам и возможность игнорирования волеизъявления избирателя (могут не учитываться бюллетени, доставленные в избирательную комиссию позднее дня голосования, бюллетени избирателей, утративших свое избирательное право на день выборов).

Наряду с почтовым голосованием в зарубежных странах получает распространение электронное голосование (e-voting), которое применяется в Бельгии, Испании, Италии, Казахстане, Нидерландах, Польше, России, США, Финляндии, Франции, ФРГ, Швейцарии ${ }^{2}$. Избирательные технологии электронного голосования стимулируют рост участия некоторых категорий граждан в выборах (молодежи; избирателей, проживающих за границей; инвалидов). При этом недостатками электронных систем голосования могут быть возможность нарушения тайны голосования и потенциальные манипуляции с голосами избирателей до окончания времени голосования на избирательном участке. Так, в Великобритании в 2008 г. было принято решение о прекращении использования комплексов электронного голосования в связи с серьезными нарушениями избирательных прав. На прошедших в 2007 г. президентских выборах во Франции возникли серьезные сбои в работе электронных средств голосования, в связи с чем была подана петиция о сохранении бумажных бюллетеней при проведении голосования³ ${ }^{3}$ В США, чтобы повысить уровень доверия избирателей к использованию технических средств голосования, в 18 штатах были приняты законодательные положения о том, что комплексы электронного голосования должны быть снабжены бумажным носителем, который сохраняет результаты голосования избирателей и может использоваться

1 CM. Electoral Commission, Absent Voting in Great Britain: report and recommendations, 25 March 2003. http://www.electoralcommission.org.uk/templates/search/document.cfm/7240; Electoral Commission Delivering democracy? The future of postal voting, 5 April 2005. http://www.electoralcommission.org.uk/templates/search/document.cfm/10935.

${ }^{2}$ См.: Забайкалов А.П. Голосование на выборах при помощи сети Интернет / Парламентаризм в России: история и современность. Материалы науч.-практ. конф. Елец: Изд-во ЕГУ, 2006. С. 46-52; Половова E.B. Голосование через Интернет: за и против / Новеллизация избирательного законодательства и актуальные проблемы его применения. Материалы науч.-практ. конф. Самара: Изд-во Самар. ун-та, 2006. С. 132-139.

${ }^{3}$ См.: Избирательное законодательство и выборы в современном мире / В.И. Лысенко, А.Г. Головин. М.: МедиаПресс, 2009. С. 51. 
для разрешения избирательных споров об итогах голосования и результатах выборов ${ }^{1}$.

Детальному правовому регулированию в зарубежных странах подвергается процесс разрешения избирательных споров.

Для защиты нарушенных избирательных прав кандидаты и партии обращаются в суд. При наличии оснований может быть назначен пересчет бюллетеней. Законодательство Испании в нарушение международных избирательных стандартов исключает возможность повторного подсчета избирательных бюллетеней. После проведения участковой избирательной комиссией подсчета избирательных бюллетеней все действительные бюллетени подлежат незамедлительному уничтожению, a недействительные или оспариваемые бюллетени сохраняются²

Законодательные акты о выборах закрепляют основания для признания выборов недействительными. Как правило, к ним относятся: подкуп избирателей, давление со стороны представителей власти, факты насилия в отношении избирателей, существенные нарушения при подсчете голосов 3 .

В судебном порядке разрешаются жалобы по поводу получения или утраты депутатских мандатов.

Необходимо отметить, что проблема обжалования результатов выборов в зарубежных странах возникает не только в связи с использованием административного ресурса и нарушениями при подсчете голосов, но и в связи со стремлением действующей власти ограничивать политическую деятельность оппозиции с помощью люстрации и оперативных методов спецслужб.

Учитывая, что результаты выборов корректируют расклад политических сил в представительных органах государственной власти и органах местного самоуправления, в ряде случаев успехи некоторых политических партий на

\footnotetext{
${ }^{1}$ Там же. С. 53.

2 Там же. С. 61.

3 В отличие от российского законодательства, предусматривающего обязательное назначение повторных выборов в случае признания выборов недействительными и несостоявшимися, законодательные акты многих европейских стран допускают безальтернативные выборы (голосование проводится по одной кандидатуре или даже не проводится, как в Великобритании).
} 
выборах рассматриваются официальными властями в качестве угрозы конституционному строю. Примером может служить правоприменительная практика Правительства Германии в отношении Левой партии (Die Linke), осуществляемая под предлогом борьбы с экстремизмом․ В 2007-2008 гг. Левая партия находилась в разработке центрального аппарата немецкой контрразведки Ведомства по защите Конституции (BFV). В ряде «западных» земель (Нижняя Саксония, Баден-Вюртемберг, Гессен, Бавария) Левая партия рассматривается как «полулегальная» политическая организация и изучается компетентными органами безопасности в качестве объекта оперативного интереса. Сразу после завершения федеральных выборов в Бундестаг в 2005г. партия испытала мощное давление со стороны СМИ в связи с т.н. «проблематикой государственной безопасности» (MFS-Problematik ${ }^{2}$ ). Руководящее партийное звено федерального и земельного уровней обвинялось в сотрудничестве со «штази».

В связи с этим необходимо упомянуть процедуру т.н. люстрации, существующую в ряде стран Центральной и Восточной Европы (Польша, Чехия, Латвия, Литва, Германия). Законодательство европейских государств, входивших в состав «социалистического лагеря» обязывает кандидатов на выборные должности представлять декларации о сотрудничестве с органами государственной безопасности, разведки или контрразведки. Например, в Польше в соответствии с Законом от 18 октября 2006 г. «О выявлении фактов работы либо службы в органах государственной безопасности либо сотрудничества с ними лиц, исполняющих публичные функции, в период 1944-1990 годы» кандидат должен внести в Государственную избирательную комиссию декларацию о своей работе либо сотрудничестве с органами государственной безопасности. Если лицо уже проходило такую проверку, оно ставит об этом в известность Государственную избирательную комиссию. Для проверки достоверности и

\footnotetext{
1 Левая партия - политическая партия в Германии, разделяющая ценности демократического социализма Правопреемница единственной правящей партии ГДР - социалистической единой партии Германии (SEPD СЕПГ), после вхождения ГДР в состав ФРГ в 1990 Г. переименована в «партию демократического социализма» (PDS - ПДС), с 2005 г. - в «Левую партию. ПДС» (Linkspartei.PDS), с 2007 г. носит название «Левая» (Linke).

${ }^{2}$ Das MFS (Ministerium fbr Staatssicherheit) - Министерство государственной безопасности ГДР («Штази»). Министерство осуществляло разведку, контрразведку, политический розыск и следствие.
} 
выявления такого рода сведений созданы суды люстрации ${ }^{1}$. В случае сокрытия факта сотрудничества со спецслужбами применяется отказ (отмена регистрации) в качестве кандидата, а сам кандидат лишается судом пассивного избирательного права сроком на 10 лет $^{2}$.

Согласно Закону Чешской Республики от 4 октября 1991 г. «О незаконности коммунистического режима» лица, сотрудничавшие с коммунистическим режимом в 1948 - 1989 гг., лишаются на 5 лет права занимать государственные должности.

Закон Латвии «О выборах в пятый Сейм» от 22 октября 1992 г. в статье 21 предусмотрел для кандидатов в депутаты парламента необходимость подачи письменного заявления о наличии или отсутствии связей с советскими (российскими) органами государственной безопасности. С 1995 г. на выборах в Сейм действует запрет на избрание бывших членов КПСС, а также работников и агентов КГБ.

В Литве был принят закон «О проверке мандатов депутатов, подозреваемых в сознательном сотрудничестве со специальными службами СССР или других государств». Для проверки и расследования фактов подобного сотрудничества предусматривалось создание специальных депутатских комиссий ${ }^{3}$.

В Германии по Закону «О документации Министерства государственной безопасности бывшей ГДР» (Gesetz ьber die Unterlagen des Staatssicherheitsdienstes der ehemaligen Deutschen Demokratischen Republik) от 20 декабря 1991 г. государственные органы получили право запрашивать из архива «штази» информацию о соискателях на государственные должности ${ }^{4}$. Наличие данных о сотрудничестве со спецслужбами ГДР рассматривается как основание для отказа в приеме на работу или увольнения с работы.

\footnotetext{
${ }_{1}^{1}$ См.: Современные избирательные системы. Вып. 1: Великобритания, Канада, Мексика, Польша. М.: Норма, 2006. C. 392-393.

${ }^{2}$ Конституционный трибунал Польши в своем решении от 11 мая 2007 г. признал допустимым снижение срока лишения пассивного избирательного права.

${ }^{3}$ См.: В. Бойцова, Л. Бойцова. Люстрация в Центральной и Восточной Европе // Правозащитник. 1999. № 3.

${ }^{4}$ CM.: http://bundesrecht.juris.de/stug/index.html.
} 
Вместе с тем, ограничение или лишение субъективных прав по профессиональному признаку, осуществляемое в порядке люстрации, как представляется, носит дискриминационный и недемократический характер. Противоправность люстрационных законов обусловлена тем, что они во внесудебном порядке ухудшают правовое положение субъектов права и распространяют свою юридическую силу на правоотношения, возникшие до момента их принятия.

Таким образом, анализ законодательства и практики проведения избирательных кампаний в зарубежных странах свидетельствует о том, что регулирование выборов в интересах защиты конституционного строя осуществляется на всех стадиях избирательного процесса. Процедура формирования органов народного представительства в целом носит свободный, справедливый и безопасный характер. Вместе с тем, в некоторых зарубежных странах отсутствуют ограничения на предвыборную агитацию в средствах массовой информации лицами, занимающими государственные должности (США), не запрещено осуществление экстремистской агитационной деятельности (Великобритания), не предусмотрены положения об обеспечении тайны голосования и возможности повторного подсчета избирательных бюллетеней (Испания), допускаются безальтернативные выборы (Великобритания), используются дискриминационные проверки кандидатов на лояльность (Германия, Литва, Латвия, Польша, Чехия), под предлогом противодействия экстремизму осуществляется борьба с политической оппозицией (Германия).

\section{3. Национальное законодательство зарубежных стран об участии компетентных государственных органов конституционного строя в избирательном процессе}

В зарубежных странах сформирована отвечающая нормам международного права законодательная основа, регулирующая вопросы защиты конституционного строя в избирательном процессе. Существующие в законодательстве иностранных государств правовые положения, касающиеся защиты конституционного строя в условиях выборов, можно условно подразделить на пять групп: 
1) ограничения на проникновение криминалитета, экстремистских и террористических элементов в органы власти;

2) запрет создания и деятельности политических партий и общественных организаций экстремистской направленности;

3) ограничения на вмешательство в избирательный процесс иностранных субъектов;

4) положения, связанные с обеспечением компетентными государственными органами и учреждениями безопасности в день голосования;

5) закрепление в уголовном законодательстве соответствующих составов преступлений, связанных с выборами.

Данные положения используются компетентными государственными органами и учреждениями зарубежных стран в интересах защиты конституционного строя в избирательном процессе.

Как свидетельствует законодательная практика зарубежных стран, право избирать и быть избранными в органы законодательной и исполнительной власти, органы местного самоуправления гарантируется конституциями, избирательными законами и иными правовыми актами. В ряде стран наказание в виде лишения свободы влечет ограничение активного избирательного права. При этом законодатель может увязывать подобные санкции с фактом вынесения наказания (законодательство государств СНГ), с определенным его сроком (более 5 лет лишения свободы - Индонезия, более одного года - Австрия), конкретным составом преступления (Италия).

В конституциях и избирательных законах устанавливаются категории лиц, не пользующихся пассивным избирательным правом. Так, Конституцией Греции пассивное избирательное право ограничивается для граждан, осужденных за тяжкие уголовные преступления. Право быть избранными в Парламент Великобритании, согласно Закону от 2 июля 1981 года «О народном представительстве» не имеют те, кто в судебном порядке признан банкротом или приговорен более чем к одному году тюремного заключения. Аналогичные 
требования в отношении лиц с криминальным прошлым свойственны законодательным актам о выборах государств СНГ ${ }^{1}$.

Компетентные государственные органы и учреждения осуществляют проверку сведений, представляемых о себе кандидатами в депутаты и на выборные должности. Результаты проверочных мероприятий являются основанием для продолжения участия кандидата в выборах либо для прекращения кандидатом избирательной кампании.

В плане организации противодействия политическому экстремизму в зарубежных странах отдельного внимания заслуживают нормативные правовые ограничения, касающиеся создания и деятельности политических партий и общественных организаций. Законодательство иностранных государств, в соответствии с общепризнанными принципами международного права, запрещает создание и деятельность экстремистских политических партий и общественных объединений, пропагандирующих и применяющих в ходе избирательного процесса насильственные методы. В случае осуществления экстремизма деятельность соответствующих политических партий, общественных организаций, СМИ приостанавливается или запрещается судом.

Как уже отмечалось, национальное законодательство зарубежных стран, как правило, закрепляет запрет финансирования избирательных кампаний иностранными государствами, организациями, юридическими лицами и гражданами, а также ограничения на участие в выборах иностранных граждан ${ }^{2}$. Компетентные государственные органы и учреждения контролируют соблюдение соответствующих предписаний участниками избирательного процесса.

При финансировании избирательных кампаний в большинстве зарубежных стран значительную роль играют доверенные лица по финансовым вопросам или

\footnotetext{
${ }^{1}$ См.: Конституционная и законодательная защита от проникновения криминальных элементов во властные структуры в государствах СНГ // Вестник ЦИК Российской Федерации. 1998. № 8 (62). С.55-67; Игнатов A.B. Ограничения всеобщего избирательного права в отношении права быть избранным в национальные парламенты государств-участников СНГ/ Научные труды РАЮН. Вып. 9. Т.1. М.: Юрист, 2009. С. 965-969; Кудрямов E.O. Право на выдвижение кандидатов на парламентских выборах в странах СНГ // Конституционное и муниципальное право. 2009. № 22. С. 25-28. Подробней об ограничении и лишении избирательного права см. параграф 3.2 монографии. выборах.

${ }^{2}$ Государства - члены Совета Европы предоставили иностранным гражданам право участия в местных
} 
специальные «казначеи». Они отвечают за финансирование избирательной кампании, при этом кандидат на выборную должность не регулирует расход денежных средств и не может осуществлять какие-либо платежи, минуя свое доверенное лицо по финансовым вопросам. Такой порядок финансирования существует в Австралии, Великобритании, Канаде, Ирландии, США. По канадскому законодательству предусматривается проведение аудиторских проверок кандидатов и отделений политических партий. Отделения политических партий проверяются аудиторами, если доходы или расходы отделения партии за год превышают 5 тысяч долларов. Аудиторская проверка кандидатов проводится в том случае, если полученные ими пожертвования или понесенные избирательные расходы превышают 10 тысяч долларов. Информация, полученная Центральным избирательным ведомством Канады в результате проверки, доводится до сведения общественности ${ }^{1}$.

Особое значение имеет деятельность компетентных государственных органов по обеспечению безопасности в день голосования. Как правило, подобная деятельность осуществляется по запросам избирательных органов полицией или органами безопасности. Соответствующие положения закреплены в статье 67 Закона Болгарии «О выборах членов Национальной Ассамблеи, членов муниципальных советов и мэров», статье 54 Закона Республики Казахстан «О выборах в Республике Казахстан», статье 43 Закона Македонии «О выборах и отзыве представителей и членов ассамблей», статье 77 Закона Молдовы «О выборах в Парламент», статье 34 Закона Польши «О выборах в Сейм», статье 65 Закона Словении «О выборах в Государственную палату», статье 38 Закона Хорватии «О выборах представителей в Парламент».

В день голосования запрещается какое-либо сосредоточение войск или проявление активности вооруженных сил. Полицейский персонал действует по указанию руководителя соответствующего органа, проводящего голосование. Полиция или органы безопасности привлекаются для разрешения конфликтов в

\footnotetext{
${ }^{1}$ См.: Современные избирательные системы. Вып. 1: Великобритания, Канада, Мексика, Польша. М.: Норма, 2006. C. 227-228.
} 
помещениях избирательных участков, обеспечения сохранности избирательной документации, охраны кандидатов, которым угрожает опасность, недопущения запугивания (подкупа) избирателей и оказания воздействия на членов избирательного органа.

Офицеры вооруженных сил и полиции не могут руководить группами граждан во время выборов, а также использовать свое должностное положение с целью оказания влияния на волеизъявление избирателей. Статья 100 Акта о народном представительстве 1983 г. устанавливает, что служащие полиции Великобритании не вправе словесно, письменно или иным способом пытаться склонить кого-либо отдать свой голос или отговаривать от подачи голоса в качестве лица, действующего по доверенности ${ }^{1}$.

Суды и прокуроры в день голосования осуществляют прием граждан. Нотариусы удостоверяют действия и подтверждают документы, относящиеся к выборам.

В ряде зарубежных стран предусмотрен упрощенный универсальный порядок защиты конституционных прав граждан в ходе избирательного процесса. Так, статья 10 Избирательного кодекса Аргентины гарантирует избирателям т.н. «nраво на ампаро». Если избиратель считает, что нарушена его неприкосновенность, свобода или безопасность или он лишен возможности осуществить право голоса, он может обратиться за защитой в форме ампаро лично или посредством другого лица от своего имени, в письменной форме или устно, изложив свое дело судье по избирательным делам, или судье общей юрисдикции, или любому должностному лицу национального или провинциального уровня, которые обязаны незамедлительно предпринять соответствующие меры для прекращения данного действия против избирателя, если сочтут его незаконным или необоснованным². Рассмотрение исков в соответствии с процедурой ампаро должностные лица и судьи обязаны проводить в устной форме. Их решения

\footnotetext{
${ }^{1}$ Там же. С. 115.

${ }^{2}$ См. Современные избирательные системы. Вып. 2: Аргентина, Германия, Швеция. М.: РЦОИт: Норма, 2007. C. 90 .
} 
незамедлительно вступают в законную силу и, если необходимо, сразу же доводятся до сведения судьи по избирательным делам ${ }^{1}$.

В избирательном законодательстве Канады установлено обязательное досудебное расследование избирательных правонарушений. В соответствии со статьей 510 Закона о выборах 2000 г., «если главное должностное лицо по выборам имеет достаточно оснований считать, что какое-либо должностное лицо совершило правонарушение или оно совершено кем-либо иным, он обращается к Комиссару с тем, чтобы последний провел расследование, которое требуется в таких случаях, что он и должен сделать» ${ }^{2}$. После проведения расследования Комиссар уполномочен принять решение о дальнейшем производстве по делу. В тех случаях, когда, по мнению Комиссара, интересы дела требуют возмещения ущерба, нанесенного одной из сторон, или проведения иных процедур, в том числе введения каких-либо запретов или выполнения необходимых действий, он обращается в судебный орган.

Для защиты конституционного строя в избирательном процессе важным является закрепление в законодательстве зарубежных стран соответствующих составов правонарушений в сфере выборов. Уголовные кодексы зарубежных государств, как правило, относят преступления, связанные с выборами, к посягательствам на конституционный строй ${ }^{3}$. Законодатель не делает принципиальных различий между насильственным захватом или удержанием власти и обманным способом ее получения в результате подкупа или шантажа избирателей, фальсификации избирательных документов, неправильного установления результатов выборов и т.п ${ }^{4}$.

В некоторых зарубежных странах (например, в Аргентине) нормы, регулирующие правоотношения, возникающие в связи с нарушением

\footnotetext{
1 Там же. С. 93.

${ }^{2}$ См.: Современные избирательные системы. Вып. 1: Великобритания, Канада, Мексика, Польша. М.: Норма, 2006. C. 183 .

3 По данному вопросу см. также Ревякина A.A. К вопросу о противодействии экстремизму в уголовном законодательстве России и ряда зарубежных стран // Юридический вестник РГЭУ. № 4. Ростов-на-Дону, 2008. С. 64-65.

${ }^{4}$ См.: Уголовное право. Особенная часть. Учебник для вузов / Под ред. Козаченко И.Я., Незнамова 3.А. М.: Издательская группа ИНФРА М-НОРМА, 1998. С. 566.
} 
установленного законом порядка проведения выборов (конкретные составы правонарушений, их существенные признаки и санкции), содержатся в самом избирательном законодательстве.

Наиболее типичными правонарушениями в условиях выборов в зарубежных странах являются:

- правонарушения, связанные с регистрацией и учетом избирателей. К ним относятся включение в список избирателей граждан, не имеющих права голосовать вообще (несовершеннолетние, иностранные граждане и т.д.); включение в списки избирателей граждан, которые уже умерли или выехали, не проживают на территории данного округа, участка; многократная регистрация и т.Д.

- правонарушения при нарезке избирательных округов и формировании избирательных участков;

- правонарушения в ходе предвыборной агитации (злоупотребление свободой массовой информации; агитация, возбуждающая социальную, расовую, национальную, религиозную ненависть и вражду; призывы к захвату власти);

- правонарушения в ходе финансирования избирательных кампаний (внесение средств через подставных лиц, выставление фиктивных счетов, платежи третьих лиц $)^{1}$;

- правонарушения на стадии голосования и определения результатов выборов (голосование за неявившихся избирателей; избирателей, находящихся в домах престарелых; граждан, которые уже умерли или не проживают на территории данного округа, участка; подкуп избирателей, манипуляции с бюллетенями для голосования вне помещения избирательного участка, многократное голосование, вынос незаполненных бюллетеней, вброс в урны поддельных бюллетеней, работа с бюллетенями неуполномоченных лиц, незаконное вмешательство в деятельность избирательной комиссии, запугивание избирателей, фальсификация результатов выборов).

${ }^{1}$ См.: Материалы для брифинга: Выборы и организация избирательного процесса в Соединенных Штатах Америки. Международный Фонд Избирательных Систем. Институт развития избирательных систем. М.: 2000. С. 135-136. 
В рамках Отдела государственного контроля Управления по уголовным делам Министерства юстиции США действует Отделение преступлений, связанных с выборами. Функции данного органа сводятся, в основном, к выявлению правонарушений в ходе выборов на федеральные должности и проведению соответствующих расследований. Отдел государственного контроля решает вопрос о наличии в совершенном деянии признаков состава преступления и передает материалы в Министерство юстиции для производства предварительного расследования либо в Федеральную избирательную комиссию для применения к нарушителям мер гражданско-правовой или административной ответственности ${ }^{1}$.

Почти во всех странах выборы проходят под контролем судебной власти. В результате этого возникли две модели контроля за законностью проведения выборов и определения результатов голосования².

В первой модели данные вопросы входят в юрисдикцию обычных судов. В одних странах споры, касающиеся выборов, может рассматривать только Верховный суд (Польша, Бенин), в других - все судебные инстанции (Украина, Узбекистан). Вторая модель предусматривает отнесение данных вопросов к ведению органов конституционной юстиции (Франция, Болгария). Например, в Чехии Конституционный суд правомочен рассматривать вопросы об обжаловании решений в отношении правильности избрания депутатов или сенаторов, а также при возникновении сомнений относительно утраты пассивного избирательного права и несовместимости должностей (пункты «д», «е» статьи 87 Конституции). В Республике Сейшельские Острова к юрисдикции Конституционного суда отнесено вынесение решений о законности избрания лица на должность президента страны (статья 51 Конституции). В Испании гражданин может обратиться в орган конституционной юстиции с заявлением о защите права в связи с провозглашением кандидатом на выборах или отказа в этом. Помимо

\footnotetext{
${ }^{1}$ См.: Материалы для брифинга: Выборы и организация избирательного процесса в Соединенных Штатах Америки. Международный Фонд Избирательных Систем. Институт развития избирательных систем. М.: 2000. С. 137.

${ }^{2}$ См.: Законодательство о выборах в зарубежных государствах. М.: Научно-методический совет при ЦИК Российской Федерации, 1998. С.14-15.
} 
контроля за избирательным процессом органы конституционного правосудия в ряде стран (Франция, Гана, Сейшельские Острова, Болгария, Чехия) рассматривают вопросы об утрате депутатского мандата. В ряде стран орган конституционного правосудия рассматривает избирательные споры по 1-й инстанции (Австрия, Венгрия, Болгария, Казахстан, Грузия, Франция), в других странах в порядке апелляции на решения других судов или парламента.

Особым фрагментом зарубежного законодательства об участии компетентных государственных органов и учреждений в защите конституционного строя в избирательном процессе являются нормативные правовые акты, регламентирующие деятельность компетентных субъектов по специальной охране политических, экономических и идеологических основ власти и созданию условий для реализации основных задач ее стратегии.

Специфика правовой регламентации деятельности компетентных государственных органов и учреждений зарубежных стран по защите конституционного строя в избирательном процессе заключается в прямом или косвенном санкционировании оперативно-розыскных и контрразведывательных мероприятий, направленных на проверку благонадежности отдельных активистов и партийных функционеров, ограничении прав и свобод неблагонадежных граждан, претендующих на депутатский мандат или выборную должность, а также на оперативное изучение «нелояльных» партий и политических организаций.

Борьба компетентных государственных органов зарубежных стран с внутренней политической оппозицией проводится под предлогом борьбы с терроризмом, политическим экстремизмом, защиты от «коммунистического проникновения〉 ${ }^{1}$.

\footnotetext{
1 Компетентные государственные органы, осуществляющие политический розыск, организационно подчинены либо органам безопасности (Национальная разведывательная организация Турции, КГБ Республики Беларусь, КНБ Казахстана, СНБ Киргизии, Государственная разведывательная служба Республики Корея, Бразильское агентство разведки, Министерство государственной безопасности КНР), либо Министерству внутренних дел (MI 5 Великобритании, Центральное управление внутренней разведки МВД Франции, Секретариат Государственной безопасности МВД Испании, полиция безопасности МВД Австрии, Ведомство по защите Конституции ФРГ), либо Министерству юстиции (ФБР, шведская полиция безопасности (СЕПО)).
} 
Радикальным средством влияния на ход политической борьбы является проводимая компетентными государственными органами и учреждениями проверка политической благонадежности кандидатов в депутаты и лиц, претендующих на выборные должности. Регулирование организации и деятельности компетентных государственных органов по осуществлению политического розыска определяется задачами и средствами, необходимыми для борьбы с политической оппозицией.

Например, в США Закон о внутренней безопасности 1950 г. (Internal Security Act of Sept. 23, 1950) позволил использовать в отношении оппозиционных партий и движений конспиративные силы и средства органов контрразведки. Закон состоит из двух титулов, каждый из которых представляет собой самостоятельный законодательный акт - Закон о контроле над подрывной деятельностью и Закон о заключении под стражу в условиях чрезвычайного положения.

Для обоснования конституционности положений Закона акцентируется внимание на представлении мирового коммунистического движения в качестве силы, создающей угрозу конституционной законности в США, американскому государству и обществу: «...Все лица в США, которые сознательно и добровольно участвуют в мировом коммунистическом движении, самим фактом подобного участия отказываются от лояльности к Соединенным Штатам и переходят в подчинение иностранного государства, осуществляющего контроль над мировым коммунистическим движением». Мотивация авторов Закона была достаточно очевидна и прозрачна: увязав огромное количество «нелояльных» партий и движений внутри страны с внешней враждебной Соединенным Штатам силой (СССР и мировым коммунистическим движением), можно было вывести их из-под защиты Билля о правах и рассматривать не как явление внутриполитической жизни США, а как внешнее враждебное воздействие на безопасность американского государства ${ }^{1}$. Хотя в целом Верховный Суд подтвердил в 1956 г. конституционность Закона о внутренней безопасности,

\footnotetext{
${ }^{1}$ Цит. по Дундуков М.Ю. Разведка в государственном механизме США. М.: Кучково поле, 2008. С. 239, 240.
} 
назвав его «частью всеобъемлющей программы противодействия различным формам тоталитарной агрессии» ${ }^{1}$, позже многие положения Закона были признаны противоречащими американской Конституции ${ }^{2}$ В ряде штатов законы, направленные на контроль за коммунистическими организациями и подрывной деятельностью, и вовсе были признаны противоречащими Конституции. В частности, в 1964 г. неконституционным был признан Закон штата Луизиана ${ }^{3}$, в 1966 - штата Кентукки ${ }^{4}$, в а 1969 - штата Огайо ${ }^{5}$.

В Германии борьба компетентных государственных органов с левым и ультраправым крылом политической оппозиции осуществляется в рамках закрепленного в Основном законе механизма защиты конституционного строя. Основной закон ФРГ содержит правовые положения, непосредственно обеспечивающие защиту конституционного строя.

В соответствии с ч.2 ст. 21 Основного закона ФРГ «партии, которые по своим целям или действиям своих сторонников стремятся причинить ущерб основам свободного демократического строя или устранить его либо поставить под угрозу существование Федеративной республики Германии, являются антиконституционными. Вопрос об антиконституционности решает Федеральный конституционный суд». Правовые последствия, связанные с признанием партии антиконституционной, детализированы в параграфах $32-33$ раздела 7 Федерального закона ФРГ от 24 июля 1967 г. (с изм. от 22 декабря 2004 г.) «О политических партиях».

На основании ст. 18 Основного Закона ФРГ «граждане, использующие право на свободу выражения мнений, печати, преподавания, свободу собраний, объединений, тайну переписки, почтовой, телеграфной и иной электросвязи, право собственности, право убежища для борьбы против основ конституционного

\footnotetext{
${ }^{1}$ CM.: Pennsylvania v. Nelson, 350 U.S. 479 (1956).
}

${ }^{2}$ В частности, в 1967 г. Верховный Суд признал неконституционным запрет для членов коммунистических организаций работать в оборонной отрасли (United States v. Robel, 389 U.S. 258 (1967)), еще раньше, в 1964 г., в результате судебного решения по делу Aptheker v. Secretary of State, 348 U.S. 500 (1964) был снят запрет на выдачу коммунистам загранпаспортов. Цит. по Дундуков М.Ю. Указ. соч.. С. 319.

${ }^{3}$ См.: Garrison v. Louisiana, 379 U.S. 64 (1964).

${ }^{4}$ CM.: Ashton v. Kentucky, 384 U.S. 195 (1966).

${ }^{5}$ См.: Brandenburg v. Ohio, 395 U.S. 444 (1969). 
строя, утрачивают эти права в соответствии с решением Федерального конституционного суда Германии».

В связи с угрозами конституционному строю (территориальной целостности государства, способности государственных органов к полноценному функционированию, обеспечению суверенитета, законности управления, безопасности населения, многопартийности и равных возможностей для участия в выборах) может быть введен режим чрезвычайного положения.

При подготовке и проведении выборов на компетентные государственные органы и учреждения зарубежных государств возлагаются следующие задачи:

- сбор и оценка информации о возникающих угрозах, направленных против свободного демократического порядка, целостности и безопасности государства либо о противоправном влиянии на осуществление полномочий конституционных органов или их сотрудников, информирование соответствующих органов и должностных лиц по вопросам защиты конституционного строя (Федеральный закон ФРГ «О сотрудничестве Федерации и земель в вопросах защиты конституции и о Ведомстве по защите конституции» 1990 г. (с изм. от 17 декабря 2008 г.), Закон Монголии «О разведывательных органах» 1999 г.);

- контроль за деятельностью враждебных или недружественных иностранных организаций (Закон «О спецслужбах Индии» 1985 г.);

- наблюдение за организациями, если их деятельность может представлять угрозу для общественной безопасности, привести к насилию по убеждениям или религиозным мотивам (Федеральный закон Австрии «О полиции безопасности» 1993 г.);

- предупреждение и пресечение деятельности политических партий и профсоюзов других государств, партий на религиозной основе, а также финансирования политических партий и профсоюзов иностранными юридическими лицами и гражданами, иностранными государствами и международными организациями (Закон «Об органах национальной безопасности Республики Казахстан» 1995 г. (в ред. от 21 марта 2002 г.)); 
- борьба с деятельностью, связанной с политическим насилием и проводимой тайными методами (Закон «О канадской службе безопасности и разведки» 1984 г., Закон Великобритании «О службе безопасности» 1989 г.). В известных пределах сюда же можно отнести и «борьбу с терроризмом и политическим экстремизмом» (Закон Австрии «О полиции безопасности» 1993 Г.);

- контроль за соблюдением законодательства о собраниях, митингах, манифестациях, обеспечение безопасности общественно-политических мероприятий (Закон «Об образовании министерств и других центральных органов государственного управления Чешской Республики» 1969 г.; Закон КНР «О народной полиции» 1995 г., Закон Республики Беларусь «Об органах государственной безопасности Республики Беларусь» 1997 г. (с изм. от 21 июля 2008 г.));

- выработка и реализация системы мер, направленных на выявление, предупреждение и пресечение действий, направленных на насильственное свержение законно избранных органов публичной власти (Закон Республики Молдова от 31 октября 1995 г. (с изм. от 9 декабря 2005 г.) № 619 «Об органах государственной безопасности»; Закон Республики Молдова от 23 декабря 1999 г. (с изм. от 13 мая 2008 г.) № 753 «О Службе информации и безопасности Республики Молдова»));

- обеспечение личной безопасности политических и общественных деятелей в случае возникновения угроз для их жизни и здоровья (Закон КНР «О народной полиции» 1995 г., Инструкция «О полиции безопасности Швеции» 2002 г. (с изм. 2007 г.)).

Вмешательство государства в процесс формирования и организации системы политической власти не должно носить тотальный характер, иначе возникает опасность устранения оппозиции, нарушения прав и свобод человека, ограничения многопартийности и идеологического многообразия, установления антидемократического государственного режима. Примером может служить известный «уотергейтский скандал» 1972 г. в США. 
Поэтому в зарубежных странах нормативно закреплены пределы вмешательства компетентных государственных органов (прежде всего, органов безопасности) в политический процесс и общественную жизнь, а также механизм контроля за их деятельностью1.

На практике существует несколько различных правовых механизмов контроля за деятельностью органов безопасности. Помимо контроля, осуществляемого главой государства (или главой правительства), в США, Германии, Италии, Дании, Нидерландах, Австралии функционируют специализированные парламентские комитеты. В Канаде контрразведка контролируется через внепарламентский комитет, состав которого определяется после консультаций премьер-министра с парламентом.

В Великобритании, Австралии и Новой Зеландии механизм контроля включает особого уполномоченного или генерального инспектора, назначаемого премьер-министром, но ответственного перед парламентом². В Великобритании и Австралии, помимо того, действуют специальные суды для рассмотрения жалоб населения на действия органов безопасности.

Рассмотренный механизм государственного контроля позволяет в определенной степени гарантировать демократические права и свободы человека и гражданина, ограничивать произвольное вмешательство компетентных государственных органов и учреждений в политический процесс, обеспечивать законность и легитимность организации и проведения выборов.

\section{Выводы:}

1. Международное правовое регулирование избирательного процесса является результатом нормотворческой деятельности международных

1 Законы Республики Корея «О Национальной разведывательной службе» 1980 г. и Великобритании «О разведывательных службах» 1994 г. запрещают органам безопасности осуществление каких-либо действий в интересах политических партий. В Законе Монголии «Об оперативной деятельности» 1998 г. содержится запрет на использование субъектами оперативной деятельности в качестве документов прикрытия удостоверений членов Парламента, Правительства, Конституционного суда, Главного комитета по выборам.

2 В соответствии с Законом Великобритании «О разведывательных службах» 1994 г. для осуществления контроля за расходами, деятельностью и управлением разведывательных и контрразведывательных органов Великобритании был создан Комитет по разведке и безопасности, состоящий из 9 человек, представляющих обе палаты Парламента. Члены Комитета назначаются Премьер-министром по согласованию с Лидером оппозиции. 
организаций (их органов) по вопросам избирательного права и избирательного процесса.

Международное правовое регулирование защиты конституционного строя в избирательном процессе представлено тремя основными фрагментами. Первый фрагмент составляют международные стандарты, закрепляющие основные требования к легитимности, справедливости, демократизму, подлинному и свободному характеру выборов. Второй фрагмент включает международные стандарты, закрепляющие государственный механизм защиты общепризнанных принципов и норм избирательного права, а также стандарты, регулирующие деятельность компетентных государственных органов и учреждений, осуществляющих защиту конституционного строя в условиях избирательного процесса. Третий фрагмент содержит международные стандарты, устанавливающие общие требования к законотворческому процессу и качеству законодательства в сфере выборов. Имплементация международных избирательных стандартов в практику выборов позволяет обеспечивать легитимность формирования органов публичной власти, законность избирательного процесса, реализацию избирательных прав и свобод граждан.

2. Анализ законодательства и практики проведения избирательных кампаний в зарубежных странах свидетельствует о том, что регулирование выборов в интересах защиты конституционного строя осуществляется на всех стадиях избирательного процесса. Процедура формирования органов народного представительства в целом носит свободный, справедливый и безопасный характер. Вместе с тем, в некоторых зарубежных странах отсутствуют правовые ограничения на осуществление экстремистской агитационной деятельности (Великобритания), используются дискриминационные проверки кандидатов на лояльность (Венгрия, Германия, Литва, Латвия, Польша, Чехия), под предлогом противодействия экстремизму осуществляется борьба с политической оппозицией (США, Германия).

3. Национальное законодательство зарубежных стран об участии компетентных государственных органов и учреждений в защите 
конституционного строя в условиях выборов основывается на правовых положениях, непосредственно обеспечивающих защиту конституционного строя. Специфика правовой регламентации деятельности компетентных государственных органов и учреждений зарубежных стран по защите конституционного строя в избирательном процессе заключается в прямом или косвенном санкционировании оперативно-розыскных и контрразведывательных мероприятий, направленных на проверку благонадежности отдельных активистов и партийных функционеров, ограничении прав и свобод неблагонадежных граждан, претендующих на депутатский мандат или выборную должность, а также на оперативное изучение «нелояльных» партий и политических организаций. С целью создания условий для функционирования гражданского общества, сохранения и развития демократической многопартийности, соблюдения законности при реализации гражданами их важнейших политических прав предусмотрен юридический механизм контроля за деятельностью компетентных государственных органов и учреждений. 


\section{ГЛАВа 4. ОСНОВНЫЕ НАПРАВЛЕНИЯ РАЗВИТИЯ ПРАВОВОГО ОБЕСПЕЧЕНИЯ ЗАЩИТЫ КОНСТИТУЦИОННОГО СТРОЯ РОССИИ В ИЗБИРАТЕЛЬНОМ ПРОЦЕССЕ}

\section{1. Развитие правового обеспечения избирательного процесса в интересах защиты конституционного строя России}

Несмотря на совершенствование российских демократических институтов и модернизацию нормативной правовой основы, связанной с выборами, в законодательстве, регулирующем организацию и проведение выборов в Российской Федерации, на сегодняшний день не полностью ликвидированы пробелы и коллизии. Они продолжают оказывать негативное воздействие на избирательный процесс и защищенность конституционного строя. В связи с этим требуется развитие правового обеспечения избирательного процесса в интересах защиты конституционного строя России, которое предполагает обновление нормативно-правового материала в соответствии с возрастающими потребностями в защите конституционного строя и возможностями правоприменительной практики.

В современных условиях на развитие правового обеспечения избирательного процесса в интересах защиты конституционного строя влияет ряд факторов.

Во-первых, профессиональный уровень и добросовестность законодателя. Профессионализм депутатского корпуса и работников аппаратов законодательных органов государственной власти имеет большое значение для качества и юридической техники издаваемых законов. При подготовке проектов законов не всегда разрабатываются концепции соответствующих законопроектов. Намерение создать закон зачастую не соизмеряется с финансовыми возможностями государства ${ }^{1}$. Негативное влияние на правовое обеспечение защиты конституционного строя оказывает лоббирование крупными политическими партиями своих корпоративных интересов в законотворческом

\footnotetext{
${ }^{1}$ См. Нормография: теория и методология нормотворчества / Под ред. д-ра юрид. наук Ю.Г. Арзамасова. М.: Академический проект, 2007. С. 249.
} 
процессе, что способствует распространению коррупции и ущемлению политических прав граждан Российской Федерации.

Во-вторых, соблюдение законодательных прочедур и временных сроков обсуждения, рассмотрения и принятия законов. В результате «ускоренного» законотворчества принимаются некачественные законы, нарушающие права и свободы граждан, подрывающие конституционный строй России ${ }^{1}$. Ложное понимание политической целесообразности скорейшего принятия законов в ущерб соблюдению объективно необходимых законодательных процедур остается доминирующим фактором принятия законодательных решений, негативно влияющих на качество законодательства.

В третьих, стабильность законодательства о выборах. Постоянные изменения правовой базы защиты конституционного строя в избирательном процессе влекут за собой слабое знание участниками избирательного процесса положений действующих нормативных правовых актов, оказывают отрицательное воздействие на профессиональную и правовую культуру организации и проведения выборов и, как следствие, способствуют росту правонарушений в сфере избирательных прав.

В четвертых, актуальной является проблема разграничения предметов ведения Российской Федераџии и ее субъектов, а также пределов нормативного правового регулирования в рассматриваемой сфере. Из статей 71 и 72 Конституции Российской Федерации непонятно, к чьему ведению (Федерации или ее субъектов) относится защита прав граждан (в том числе и избирательных). В связи с этим представляется необходимым более четко законодательно закрепить предметы нормативного правового регулирования Российской Федерации и субъектов Российской Федерации, а также установить четкие рамки государственно-властного вмешательства в избирательный процесс. В законодательном процессе следует обеспечить гарантии учета мнения субъектов

1 Ч. 1 и 8 ст. 119 раздела III Регламента Государственной Думы Федерального Собрания Российской Федерации от 22 января 1998 г. № 2134-ІІ ГД (с изм. от 20 января 2010 г.) устанавливают возможность принятия закона без процедур второго и третьего чтений. Подобная норма облегчает возможность «протаскивания» выгодных лоббистам законов. 
Российской Федерации при разработке и принятии федеральных законов (в том числе о выборах $)^{1}$.

B-пятых, наличие определенного опыта защиты конституционного строя 8 избирательном прочессе. Правоприменительная практика защиты конституционного строя в избирательном процессе позволяет выявлять коллизии и пробелы в правовом регулировании и заметно влияет на формирование соответствующей нормативной правовой основы.

Развитие правового обеспечения избирательного процесса в интересах защиты конституционного строя России должно проходить путем совершенствования законодательной и подзаконной правовой основы.

Совершенствование законодательной основы, как представляется, необходимо осуществлять по следующим направлениям:

1. Совершенствование законодательной основы организации и проведения выборов в целях обеспечения соответствия международных обязательств России интересам защиты ее конституционного строя.

Эту работу следует проводить как в отношении не вступивших в законную силу на территории Российской Федерации международных правовых актов (актов СНГ), так и в отношении действующих международных договоров (актов СНГ) и федеральных законов в сфере выборов.

Главную роль в процессе приведения в соответствие с Конституцией и интересами защиты конституционного строя не вступивших в законную силу международных договоров Российской Федерации (в том числе актов СНГ) в сфере выборов должны играть Конституционный Суд Российской Федерации и Федеральное Собрание Российской Федерации ${ }^{2}$ В соответствии с пунктом «г» части 2 статьи 125 Конституции Конституционный Суд Российской Федерации разрешает дела о соответствии Конституции Российской Федерации не

${ }^{1}$ Примером реализации подобного подхода следует считать подписание 27 мая 2009 г. Соглашения между Советом Федерации Федерального Собрания Российской Федерации и 13 законодательными органами государственной власти субъектов Российской Федерации (Республика Карелия, Республика Мордовия, Республика Саха, Чеченская Республика, Алтайский край, Краснодарский край, Иркутская область, Московская область, Оренбургская область, Курская область, Псковская область, Сахалинская область, Свердловская область) о взаимодействии в федеральном законодательном процессе.

2 В настоящее время Конституционный Суд Российской Федерации лишен права принимать к производству дела по своей инициативе, что существенно сокращает эффективность судебного конституционного контроля. В связи с этим представляется целесообразным внести изменения в действующее конституционное законодательство, которые бы закрепили право Конституционного Суда Российской Федерации на самостоятельное принятие к своему рассмотрению дел. 
вступивших в силу международных договоров Российской Федерации, разрешает споры о компетенции между федеральными органами государственной власти, а также органами государственной власти Российской Федерации и органами государственной власти субъектов Российской Федерации в связи с заключенными международными договорами.

Не соответствующие Конституции России международные договоры Российской Федерации не подлежат введению в действие и применению.

Статья 7 Федерального закона от 15 июля 1995 года № 101-Ф3 «О международных договорах Российской Федерации» содержит норму об обязанности Министерства иностранных дел Российской Федерации информировать Федеральное Собрание Российской Федерации о заключенных от имени Российской Федерации и от имени Правительства Российской Федерации международных договорах, о прекращении и приостановлении их действия ${ }^{1}$.

В части 4 статьи 15 Конституции Российской Федерации закреплено положение, что «если вступившим в силу международным договором Российской Федерации установлены иные правила, чем предусмотренные законом, то применяются правила международного договора». Нератифицированные межгосударственные, межправительственные и межведомственные договоры, в отличие от вступивших в силу международных договоров, не обладают приоритетом над национальным законодательством Российской Федерации.

В соответствии с Федеральным законом «О международных договорах Российской Федерации» общее наблюдение за выполнением обязательств Российской Федерации, вытекающих из международных договоров, осуществляет Министерство иностранных дел Российской Федерации.

В настоящее время Российская Федерация выполняет обязательства в рамках следующих международных правовых актов, регулирующих вопросы организации и проведения выборов: Конвенции о защите прав человека и основных свобод (Рим, 4 ноября 1950) (с изм. и доп. от 21 сентября 1970 г., 20 декабря 1971 г., 1 января 1990 г., 6 ноября 1990 г., 11 мая 1994 г.) Декларации о критериях свободных и справедливых выборов (Париж, 26 марта 1994 года), Руководства по наблюдению за выборами ОБСЕ / БДИПЧ (Варшава, 1997 г.),

\footnotetext{
${ }^{1}$ См. СЗ РФ. 1995. № 29. Ст. 2757.
} 
Декларации Стамбульской встречи на высшем уровне (Стамбул, 19 ноября 1999 года), Хартии Европейской безопасности ОБСЕ (Стамбул, 19 ноября 1999 года), Документа Копенгагенского Совещания Конференции по человеческому измерению СБСЕ (Копенгаген, 29 июня 1990 года) и ряда других международных стандартов.

В рамках Содружества Независимых Государств Российская Федерация руководствуется Конвенцией о стандартах демократических выборов, избирательных прав и свобод в государствах-участниках Содружества Независимых Государств (Кишинев, 7 октября 2002 года) и Рекомендациями Межпарламентской Ассамблеи государств - участников Содружества Независимых Государств для международных наблюдателей Содружества Независимых Государств по наблюдению за выборами и референдумами ${ }^{1}$ Конвенция является не только эффективным средством укрепления демократической государственности в странах СНГ, но и своеобразным инструментом коллективной безопасности при организации и проведении выборов на постсоветском пространстве. Согласованное развитие избирательных систем, сформировавшихся в рамках ОБСЕ, Совета Европы и СНГ, несомненно, укрепляет безопасность не только Российской Федерации, но и всей Европы.

Долговременным политическим интересам Российской Федерации в сфере защиты конституционного строя отвечают Федеральные законы от 5 марта 2004 г. № 7-Ф3 «О ратификации Соглашения между государствами - членами Шанхайской организации сотрудничества о Региональной антитеррористической Структуре» и от 28 декабря 2004 г. № 176-Ф3 «О ратификации Договора о сотрудничестве государств-участников СНГ в борьбе с терроризмом» ${ }^{2}$. В результате принятия данных законодательных актов создана правовая основа регионального международного сотрудничества в борьбе с терроризмом, сепаратизмом и экстремизмом, в том числе и в условиях выборов. В то же время в целях обеспечения соответствия международных обязательств Российской

\footnotetext{
${ }^{1}$ См.: Вестник ЦИК России. 2002. № 11. С. 218-280; Конвенция о стандартах демократических выборов, избирательных прав и свобод в государствах - участниках Содружества Независимых Государств: Документы и материалы. М.: РЦОИТ, 2008. С. 185-243.

2 См. СЗ РФ. 2004. № 10. Ст. 833; 2005. № 1 (ч. 1). Ст. 2.
} 
Федерации интересам защиты еe конституционного строя представляется целесообразным активизировать деятельность по заключению межгосударственных, межправительственных и межведомственных договоров о противодействии экстремистской деятельности и пропаганде терроризма с использованием сети «Интернет».

В интересах защиты конституционного строя Российской Федерации требуется совершенствование существующего механизма проведения проверок наличия у кандидатов в депутаты или на выборные должности двойного гражданства или вида на жительство иностранного государства. В ряде случаев государственному органу известны серия и номер паспорта, дата его выдачи, орган, выдавший паспорт, а также место постоянной регистрации кандидата на территории иностранного государства, но при этом не всегда возможно получить официальное подтверждение данной информации ${ }^{1}$. Это связано с отсутствием у Российской Федерации международных соглашений $\mathrm{c}$ иностранными государствами, в том числе и государствами-участниками СНГ о предоставлении подобного рода информации.

Нуждается в разработке и нормативная правовая база, касающаяся защиты конституционных прав российских граждан при проведении выборов на избирательных участках, образованных за пределами территории Российской Федерации.

2. Другим направлением совершенствования законодательной основы является ее приведение в соответствие интересам защиты конституционного строя и повышение качества федеральных законов.

В первую очередь, следует отметить необходимость издания Избирательного Кодекса Российской Федерации, обобщающего весь массив федерального законодательства о выборах ${ }^{2}$. В данном кодифицированном акте можно было бы отразить положение о том, что в случае внесения изменений в

\footnotetext{
1 См. Выступление заместителя Председателя ЦИК России С.В. Вавилова «Роль правоохранительных органов в обеспечении безопасности выборов» на ежегодной Конференции Ассоциации организаторов выборов стран Европы (АОВСЕ) 10-13 сентября 2008 года, Румыния // www.cikrf.ru

2 По данному вопросу см. также Колюшин Е.И. Концепция модернизации избирательного и связанного с ним законодательства // Вестник Московского ун-та. 2010. № 1. С.78; Биктагиров Р.Т. Субъект избирательного права Российской Федерации: конституционно-правовое исследование. Автореф. дис. ... д-ра юрид. наук. М., 2010. С. 50.
} 
законодательство о выборах новеллы законов о выборах вступают в силу после проведения очередных избирательных кампаний. Представляется, что реализация в Избирательном Кодексе подобного правового предписания воспрепятствовала бы конъюнктурному изменению законодательства о выборах.

Отдельным блоком следует рассматривать нормы Федеральных законов «Об основных гарантиях избирательных прав и права на участие в референдуме граждан Российской Федерации», «О выборах Президента Российской Федерации», «О выборах депутатов Государственной Думы Федерального Собрания Российской Федерации», «Об обеспечении конституционных прав граждан Российской Федерации избирать и быть избранными в органы местного самоуправления» и предложения по их дальнейшему совершенствованию.

Согласно пункту 6 статьи 1 Федерального закона от 12 июня 2002 г. № 67Ф3, в случае, если федеральные законы, конституции (уставы), законы субъектов Российской Федерации, иные нормативные правовые акты о выборах, принимаемые в Российской Федерации, противоречат ему, применяются нормы данного закона. Данное положение о верховенстве юридической силы Федерального закона «Об основных гарантиях избирательных прав и права на участие в референдуме граждан Российской Федерации» над другими федеральными законами нарушает установленную Конституцией Российской Федерации иерархию нормативных правовых актов и требует устранения ${ }^{1}$

В настоящее время в Федеральном законе от 12 июня 2002 г. № 67-Ф3 не закреплены гарантии участия непарламентских партий в работе избирательных комиссий. В связи с изложенным пункт 4 статьи 21 Федерального закона от 12 июня 2002 г. № 67-ФЗ можно было бы дополнить следующим предложением: «Политические партии, федеральные списки кандидатов которых не допущены к распределению депутатских мандатов в Государственной Думе Федерального Собрания Российской Федерации, а также региональные отделения этих политических партий, списки кандидатов которых не допущены к распределению депутатских мандатов в законодательных (представительных) органах государственной власти субъектов Российской Федерации, могут назначить по

\footnotetext{
${ }^{1}$ См. Приложение.
} 
одному представителю от каждой партии для участия в работе Центральной избирательной комиссии Российской Федерации с правом совещательного голоса».

Пункт 1 статьи 22 данного Федерального закона предлагается в следующей редакции: «Избирательные комиссии субъектов Российской Федерации, избирательные комиссии муниципальных образований, окружные избирательные комиссии, территориальные, участковые комиссии формируются на основе предложений политических партий, выдвинувших списки кандидатов на выборах в Государственную Думу Федерального Собрания Российской Федерации, законодательный $\quad$ (представительный) орган $\quad$ государственной $\quad$ власти соответствующего субъекта Российской Федерации. Пункт 2 статьи 22 можно было бы сформулировать следующим образом: «Избирательные комиссии муниципальных образований, окружные избирательные комиссии по выборам в органы местного самоуправления, территориальные, участковые комиссии формируются на основе предложений, указанных в пункте 1 настоящей статьи, а также предложений избирательных объединений, выдвинувших списки кандидатов на выборах в представительный орган муниципального образования».

Нуждается в корректировке пункт 6 статьи 70 Федерального закона от 12 июня 2002 г. № 67-Ф3. Существующая редакция закона позволяет лидерам партийных списков «продвигать» в законодательные органы государственной власти основное количество кандидатов из списков, а затем без каких-либо юридических последствий отказываться от полученных мандатов ${ }^{1}$

Коррупционная возможность закреплена в пункте 7 статьи 70 Федерального закона от 12 июня 2002 г. № 67-Ф3. Законодателем предусмотрено, что если кандидат без вынуждающих к тому обстоятельств не сложил с себя полномочия, несовместимые со статусом депутата, выборного должностного лица, в результате чего назначены повторные выборы, этот кандидат должен полностью или частично возместить соответствующей избирательной комиссии произведенные ею расходы, связанные с проведением повторных выборов. Объем возмещения

\footnotetext{
${ }^{1}$ См. Приложение.
} 
расходов на проведение повторных выборов зависит от усмотрения избирательной комиссии, что указывает на наличие коррупционного фактора ${ }^{1}$.

Формулировки частей 7-10 статьи 91 Федерального закона от 18 мая 2005 г. № 51-Ф3, связанные с возможностью отмены решения Центральной избирательной комиссии Российской Федерации о регистрации списка кандидатов, об отказе в его регистрации, об исключении группы кандидатов из списка кандидатов, с отменой регистрации федерального списка кандидатов, отменой регистрации кандидатов, включенных в зарегистрированный федеральный список кандидатов, с исключением региональной группы кандидатов из федерального списка, допускают возможность выборочного правоприменения и нарушения равного статуса субъектов избирательного процесса. В соответствии с подпунктом «б» пункта 8 Методики проведения экспертизы проектов нормативных правовых актов и иных документов в целях выявления в них положений, способствующих созданию условий для проявления коррупции, утвержденной Постановлением Правительства Российской Федерации от 5 марта 2009 г. № 196, диспозитивное установление возможности совершения органом государственной власти действий в отношении граждан и организаций является коррупционным фактором. Поэтому словосочетание «может быть» в частях 7-10 статьи 91 Федерального закона от 18 мая 2005 г. № 51-Ф3 предлагается заменить словосочетанием «должна быть».

Действующее законодательство не предусматривает права выдвижения кандидатов избирателями и группами избирателей. Исключение составляет пункт 2 статьи 34 Федерального закона от 10 января 2003 г. № 19-Ф3, который определяет необходимость поддержки самовыдвижения кандидата на должность Президента Российской Федерации группой избирателей в количестве не менее 500 граждан Российской Федерации, обладающих активным избирательным правом. Думается, что лишение избирателей, не являющихся членами политических партий, права самовыдвижения кандидатами на выборах в Государственную Думу Федерального Собрания Российской Федерации,

\footnotetext{
${ }^{1}$ См. Приложение.
} 
нарушило равенство политических прав партийных и беспартийных граждан Российской Федерации. Решение о выдвижении граждан, не являющихся членами политической партии, зависит от усмотрения руководства политической партии и не предусматривает возможности обжалования, что можно рассматривать как косвенное ограничение пассивного избирательного права беспартийных граждан Российской Федерации. Согласно подпункту «в» пункта 8 Методики проведения экспертизы проектов нормативных правовых актов и иных документов в целях выявления в них положений, способствующих созданию условий для проявления коррупции, утвержденной Постановлением Правительства Российской Федерации от 5 марта 2009 г. № 196, наличие завышенных требований к лицу, предъявляемых для реализации принадлежащего ему права, является коррупционным фактором ${ }^{1}$.

Эффективность законодательного противодействия коррупции в избирательном процессе можно было бы повысить путем введения в Кодекс Российской Федерации об административных правонарушениях статьи 5.16.1 «Получение избирателем (участником референдума) выгоды материального и (или) нематериального характера за осуществление волеизъявления»².

Последовательное осуществление государственной политики в сфере противодействия коррупции в избирательном процессе обусловливает необходимость лишения пассивного избирательного права кандидатов, осуществляющих в период избирательной кампании подкуп избирателей либо благотворительную деятельность с нарушением законодательства о выборах. С учетом этого подпункт «в» пункта 3.2 статьи 4 Федерального закона от 12 июня 2002 г. № 67-Ф3, подпункт 3 пункта 5.2 статьи 3 Федерального закона от 10 января 2003 г. № 19-Ф3, пункт 3 части 4.2 статьи 5 Федерального закона от 18 мая 2005 г. № 51-Ф3, определяющие основания лишения пассивного избирательного права граждан Российской Федерации, нуждаются в дополнении статьей 5.16 Кодекса Российской Федерации об административных правонарушениях. Таким

\footnotetext{
${ }^{1}$ См. Приложение.

${ }^{2}$ См. Приложение.
} 
образом, помимо лиц, подвергнутых административному наказанию за совершение административных правонарушений, предусмотренных статьями 20.3 и 20.29 КоАП РФ, будут на законных основаниях лишены права быть избранными лица, подвергнутые административному наказанию за совершение административного правонарушения, предусмотренного статьей 5.16 КоАП РФ «Подкуп избирателей, участников референдума либо осуществление в период избирательной кампании, кампании референдума благотворительной деятельности с нарушением законодательства о выборах и референдумах».

В Федеральном законе от 12 июня 2002 г. № 67-ФЗ требует урегулирования вопрос, связанный с выносом гражданами, участвующими в выборах, избирательных бюллетеней из помещения для голосования ${ }^{1}$. В настоящее время подобные действия никак не ограничиваются. Между тем, технология, основанная на использовании данного правового пробела, в ряде случаев применяется недобросовестными кандидатами и представителями избирательных объединений как для подкупа избирателей, так и в качестве предлога для противоправных обвинений избирательных комиссий в фальсификации итогов голосования и результатов выборов. В Кодекс Российской Федерации об административных правонарушениях было бы целесообразно добавить статью 5.2 «Нарушение запрета на вынос избирательных бюллетеней из помещения для голосования» ${ }^{2}$.

С учетом значимости формирования Государственной Думы Федерального Собрания Российской Федерации на началах законности и недопущения избрания в качестве депутатов российского Парламента лиц, избранных с массовыми нарушениями законодательства о выборах, представляется важным дополнить статью 84 Федерального закона от 18 мая 2005 г. № 51-Ф3 нормой о недопустимости выдвижения и регистрации федеральных списков кандидатов при проведении повторных выборов депутатов Государственной Думы Федерального Собрания Российской Федерации политическими партиями,

\footnotetext{
${ }^{1}$ См. Приложение.

${ }^{2}$ См. Приложение.
} 
действия (бездействие) руководителей и уполномоченных представителей которых послужили (послужило) основанием для признания выборов судом недействительными ${ }^{1}$.

В рамках дальнейшего противодействия проникновению лиц, причастных к преступной деятельности, в органы государственной власти и органы местного самоуправления в федеральных законах о выборах предлагается закрепить обязательность указания кандидатами в депутаты и (или) на выборные должности всех имеющихся судимостей (в т.ч. снятых и погашенных), а также информирования политическими партиями и избирательными комиссиями избирателей о всех судимостях кандидатов с названиями составов преступлений, наименованием суда, вынесшего приговор, срока и вида наказания, даты освобождения. Пункт 58 статьи 2 Федерального закона от 12 июня 2002 г. № 67Ф3 также потребует внесения необходимых изменений ${ }^{2}$.

Учитывая долгосрочный характер оказания рядом иностранных государств информационно-пропагандистского, финансового, политического и силового воздействия на избирательный процесс в ущерб конституционному строю России, срок, предусмотренный законодателем в подпункте «п» пункта 6 статьи 58 Федерального закона от 12 июня 2002 г. № 67-Ф3, в пункте 6.1 статьи 58 Федерального закона от 10 января 2003 г. № 19-Ф3, подпункте 16 части 7 статьи 64 Федерального закона от 18 мая 2005 г. № 51-Ф3 - предшествующий дню внесения пожертвования в избирательный фонд, предлагается увеличить до двух лет ${ }^{3}$. Таким образом, некоммерческие организации, получавшие финансовую и иную материальную поддержку от иностранных государств, иностранных организаций, иностранных граждан и лиц без гражданства, международных организаций и международных общественных движений, а также от иных, указанных в законе органов и организаций в течение двух лет, предшествующих дню внесения пожертвования в избирательный фонд, не смогут вносить

\footnotetext{
${ }^{1}$ См. Приложение.

${ }^{2}$ См. Приложение.

${ }^{3}$ См. Приложение.
} 
указанные пожертвования для финансирования избирательной кампании, не возвратив полученные этими некоммерческими организациями денежные средства либо иное имущество. Предложенная мера позволила бы усилить от иностранного вмешательства и административного ресурса должностных лиц органов государственной власти и органов местного самоуправления правовую защиту конституционного строя России.

Статью 18 Федерального закона «О некоммерческих организациях» «Ликвидация некоммерческой организации» было бы логично дополнить п. 2.2 о сроках лишения иностранной некоммерческой неправительственной организации (ее структурного подразделения) права осуществлять деятельность на территории Российской Федерации ${ }^{1}$.

Необходимость обеспечения избирательного права уязвимых слоев населения (инвалидов, лежачих больных и лиц с физическими недостатками), создания дополнительных гарантий досрочного голосования отдельных категорий граждан (лиц, осуществляющих трудовую деятельность вахтовым методом, граждан Российской Федерации, находящихся в заграничных командировках или постоянно проживающих за пределами территории Российской Федерации) и голосования избирателей, проживающих или работающих в труднодоступных и отдаленных местностях, определяют актуальность принятия Федерального закона «О голосовании по почте при проведении выборов в органы государственной власти и органы местного самоуправления». В данном Федеральном законе представляется целесообразным закрепить возможность обращения в территориальную комиссию по телефону и Интернету (e-mail). Никакой уязвимости избирательного процесса при этом не возникнет, поскольку для получения письма с отметкой «выборное» избирателю (его представителю) необходимо явиться в почтовое отделение и предъявить документы, удостоверяющие личность. В то же время внедрение в деятельности избирательных комиссий Интернет-технологий послужит подготовительным этапом для перспективного внедрения электронного голосования на выборах. С

\footnotetext{
${ }^{1}$ См. Приложение.
} 
организационной точки зрения данное решение потребует разработки сайтов территориальных и участковых избирательных комиссий и дополнения реестров учета обращений избирателей разделами «обращения избирателей по телефону», «обращения избирателей по Интернету».

Дополнительной защите избирательных прав граждан послужило бы введение административной ответственности за умышленное задержание, вскрытие и повреждение выборной корреспонденции, а также за голосование по почте за другое лицо или умышленное многократное голосование по почте.

Необходимость технического переоснащения избирательной системы в Российской Федерации обусловливает развитие правового обеспечения избирательного процесса с позиций нормативного регулирования внедрения орбитальных систем «Глонасс» и «Гонец», устройств электронного голосования, комплексов обработки избирательных бюллетеней, веб-камер в помещениях избирательных комиссий в ходе проведения голосования и подведения его итогов, а также электронного документооборота и информационного сопряжения ГАС «Выборы» с информационными системами других государственных и муниципальных органов. В целях ускоренного внедрения технических средств подсчета голосов и обработки информации из пункта 15 статьи 64 Федерального закона «Об основных гарантиях избирательных прав и права на участие в референдуме граждан Российской Федерации» необходимо исключить норму, ограничивающую применение электронного голосования $1 \%$ избирательных участков ${ }^{1}$.

Необходимо отметить, что федеральные законы сами по себе могут стимулировать возникновение и реализацию внутренних угроз конституционному строю, возникающих в избирательном процессе.

Например, в статье 12 Федерального закона от 26 ноября 1996 г. (в ред. от 9 ноября 2009 г.) № 138-Ф3 «Об обеспечении конституционных прав граждан Российской Федерации избирать и быть избранными в органы местного самоуправления» отсутствуют ограничения в отношении членов избирательной

\footnotetext{
${ }^{1}$ См. Приложение.
} 
комиссии, связанные с гражданством иностранного государства. Не соответствует другим федеральным законам о выборах и законодательное перечисление перечня субъектов, которым запрещено вносить добровольные пожертвования в избирательные фонды. Не соответствует формулировкам Федерального закона «О противодействии экстремистской деятельности» статья 28, устанавливающая ограничения при проведении предвыборной агитации.

Несовершенство Федерального закона «Об обеспечении конституционных прав граждан Российской Федерации избирать и быть избранными в органы местного самоуправления» усугубляется тем, что он не содержит положений о деятельности контрольно-ревизионных служб при избирательных комиссиях и не регулирует порядок использования ГАС «Выборы». В существующем виде данный Федеральный закон не отвечает потребностям правового обеспечения защиты конституционного строя России в избирательном процессе.

В федеральном избирательном законодательстве требует решения вопрос о праве избирательных комиссий субъектов Российской Федерации принимать нормативные правовые акты по вопросам своей компетенции. Региональный фрагмент нормативного правового регулирования выборов, представленный нормативными правовыми актами избирательных комиссий субъектов Российской Федерации по предмету своего ведения, является необходимым элементом избирательного законодательства субъектов Российской Федерации о выборах. Поэтому нормотворческие полномочия избирательных комиссий субъектов Российской Федерации должны быть законодательно закреплены.

Ключевой проблемой является чрезмерная детализация избирательных действий и процедур в федеральных законах, которая не оставляет возможностей для учета исторических, культурных, социально-экономических, национальных традиций в деятельности региональных законодателей. Такая практика поощряет дублирование соответствующих правовых норм в нормативных правовых актах субъектов Российской Федерации и перенесение недостатков федеральных законодательных актов на региональный уровень. 
3. Важным направлением совершенствования законодательной основы защиты конституционного строя в избирательном процессе является приведение в соответствие федеральному законодательству и повышение качества законодательства субъектов Российской Федерации о выборах.

Главенствующее место в массиве законодательства субъектов Российской Федерации о выборах занимают конституции республик, уставы краев, областей, городов федерального значения, автономных образований. В уставах ряда субъектов Российской Федерации присутствуют разделы (главы), посвященные избирательной системе (Еврейская автономная область, Волгоградская область, Тверская область, Тульская область, Рязанская область). Это значительно повышает гарантии избирательных прав граждан на региональном уровне, эффективность правоприменительной деятельности избирательных комиссий и иных участников избирательного процесса. К положительным чертам законодательства о выборах отдельных субъектов Российской Федерации следует отнести высокий уровень обобщения норм избирательного законодательства в кодифицированных актах. В целом правовая основа региональных выборов является достаточной для реализации всех избирательных действий и процедур.

Вместе с тем анализ уставов и законов субъектов Российской Федерации о выборах показывает, что в некоторых из них сохраняются противоречия и несоответствие правовых положений нормам федерального законодательства. Так, ст. 31 Устава Ярославской области от 23 мая 1995 г. (в ред. от 25 февраля 2009 г.) не запрещает избираться лицам, осужденным к лишению свободы за совершение тяжких и (или) особо тяжких преступлений и имеющим на день голосования на выборах неснятую и непогашенную судимость за указанные преступления; осужденным за совершение преступлений экстремистской направленности, предусмотренных Уголовным кодексом Российской Федерации, и имеющим на день голосования на выборах неснятую и непогашенную судимость за указанные преступления; подвергнутым административному наказанию за совершение административного правонарушения, предусмотренного статьей 20.3 Кодекса Российской Федерации об 
административных правонарушениях, если голосование на выборах состоится до окончания срока, в течение которого лицо считается подвергнутым административному наказанию.

Аналогичные пробелы имеют Закон Республики Тыва от 23 июня 2006 г. (в ред. от 25 июля 2007 г.) № 1867 ВX-1 «О выборах депутатов Палаты представителей Великого Хурала Республики Тыва», законы Тульской области от 8 июля 2008 г. (в ред. от 19 ноября 2009 г.) № 1055-3ТО «О регулировании отдельных правоотношений, связанных с выборами депутатов представительных органов муниципальных образований, членов иных выборных органов местного самоуправления», от 18 июля 2008 г. № 1066-3ТО «О регулировании отдельных правоотношений, связанных с выборами главы муниципального образования, иного выборного должностного лица местного самоуправления», от 19 декабря 2008 г. (в ред. от 3 июня 2009 г.) № 1198-3ТО «О регулировании отдельных правоотношений, связанных с выборами депутатов Тульской областной Думы», Закон Еврейской автономной области от 29 марта 2006 г. (в ред. от 31 мая 2006 г.) № 662-О3 «О выборах депутатов Законодательного Собрания Еврейской автономной области».

В Законе Республики Коми от 7 июля 2006 г. (в ред. от 17 февраля 2010 г.) «О выборах, референдумах и опросе в Республике Коми», законах Тульской области от 8 июля 2008 г. (в ред. от 19 ноября 2009 г.) № 1055-3ТО «О регулировании отдельных правоотношений, связанных с выборами депутатов представительных органов муниципальных образований, членов иных выборных органов местного самоуправления», от 18 июля 2008 г. № 1066-3ТО «О регулировании отдельных правоотношений, связанных с выборами главы муниципального образования, иного выборного должностного лица местного самоуправления», от 19 декабря 2008 г. (в ред. от 3 июня 2009 г.) № 1198-3ТО «О регулировании отдельных правоотношений, связанных с выборами депутатов Тульской областной Думы» отсутствуют ограничения на предвыборную агитацию на предмет недопущения экстремизма. 
Закон Ставропольского края от 26 июня 2008 г. (в ред. от 29 июня 2010 г.) № 37-КЗ «О некоторых вопросах проведения выборов в органы местного самоуправления», Закон Волгоградской области от 25 октября 2008 г. № 1751-ОД «О выборах депутатов Волгоградской областной Думы», Закон Республики Коми от 7 июля 2006 г. (в ред. от 17 февраля 2010 г.) № 65-Р3 «О выборах, референдумах и опросе в Республике Коми», законы Тульской области от 8 июля 2008 г. (в ред. от 19 ноября 2009 г.) № 1055-3ТО «О регулировании отдельных правоотношений, связанных с выборами депутатов представительных органов муниципальных образований, членов иных выборных органов местного самоуправления», от 18 июля 2008 г. № 1066-3ТО «О регулировании отдельных правоотношений, связанных с выборами главы муниципального образования, иного выборного должностного лица местного самоуправления», от 19 декабря 2008 г. (в ред. от 3 июня 2009 г.) № 1198-3ТО «О регулировании отдельных правоотношений, связанных с выборами депутатов Тульской областной Думы» не содержат никаких положений о контрольно-ревизионных службах при избирательных комиссиях.

Закон Брянской области от 23 января 2008 г. (с изм. от 11 ноября 2008 г.) № 4-3 «О выборах депутатов Брянской областной Думы» не регулирует порядок использования ГАС «Выборы». Аналогичные правовые положения отсутствуют в законах Тульской области от 8 июля 2008 г. (в ред. от 19 ноября 2009 г.)№ 1055 ЗТО «О регулировании отдельных правоотношений, связанных с выборами депутатов представительных органов муниципальных образований, членов иных выборных органов местного самоуправления», от 18 июля 2008 г. № 1066-3ТО «О регулировании отдельных правоотношений, связанных с выборами главы муниципального образования, иного выборного должностного лица местного самоуправления», от 19 декабря 2008 г. (в ред. от 3 июня 2009 г.) № 1198-3ТО «О регулировании отдельных правоотношений, связанных с выборами депутатов Тульской областной Думы», Законе Ставропольского края от 26 июня 2008 г. (в ред. от 29 июня 2010 г.) № 37-КЗ «О некоторых вопросах проведения выборов в органы местного самоуправления», а также в Законе Республики Коми от 7 июля 
2006 г. (в ред. от 17 февраля 2010 г.) «О выборах, референдумах и опросе в Республике Коми».

В законодательстве ряда субъектов Российской Федерации (Республика Ингушетия, Чеченская Республика, Ивановская область, Тамбовская область) закреплено коррупциогенное положение о том, что если кандидат без вынуждающих к тому обстоятельств не сложил с себя полномочия, несовместимые со статусом депутата, выборного должностного лица, в результате чего назначены повторные выборы, этот кандидат должен полностью или частично возместить соответствующей избирательной комиссии произведенные ею расходы, связанные с проведением повторных выборов ${ }^{1}$. Таким образом, объем возмещения расходов на проведение повторных выборов зависит от усмотрения избирательной комиссии. В целях устранения возможности выборочного правоприменения из статьи 81 Закона Республики Ингушетия от 28 мая 2009 г. № 24-Р3 «О муниципальных выборах в Республике Ингушетия», статьи 83 Закона Чеченской Республики от 10 мая 2007 г. (в ред. от 21 июля 2009 г.) № 32-Р3 «О муниципальных выборах в Чеченской Республике», пункта 10 статьи 56 Закона Ивановской области от 27 июня 2003 г. (в ред. от 17 июня 2008 г.) № 60-О3 «О выборах», части 3 статьи 84 Закона Тамбовской области от 31 января 2007 г. (в ред. от 1 июля 2009 г.) № 146-3 «О выборах депутатов представительных органов муниципальных образований в Тамбовской области» предлагается исключить словосочетание «или частично».

В ряде случаев результатами регионального законотворчества становятся непроработанные с точки зрения юридической техники нормативные правовые акты. Например, Закон Республики Коми от 7 июля 2006 г. (в ред. от 17 февраля 2010 г.) № 65-Р3 «О выборах, референдумах и опросе в Республике Коми» не оправдывает своей сущности как сводного акта повышенной стабильности и определяет лишь особенности выборов, референдумов и республиканского опроса населения в республике. Он носит весьма фрагментарный характер, что усложняет правоприменительный процесс. В Законе Псковской области от 1

\footnotetext{
1 Законодательные органы власти указанных субъектов Российской Федерации продублировали в законах о выборах коррупциогенное положение пункта 7 статьи 70 Федерального закона от 12 июня 2002 г. № 67-Ф3.
} 
августа 2003 г. (в ред. от 5 ноября 2009 г.) № 295-ОЗ «Избирательный кодекс Псковской области» отсутствует общая часть, а в законах Тульской области от 8 июля 2008 г. № (в ред. от 19 ноября 2009 г.) 1055-3ТО «О регулировании отдельных правоотношений, связанных с выборами депутатов представительных органов муниципальных образований, членов иных выборных органов местного самоуправления», от 18 июля 2008 г. № 1066-3ТО «О регулировании отдельных правоотношений, связанных с выборами главы муниципального образования, иного выборного должностного лица местного самоуправления», от 19 декабря 2008 г. (в ред. от 3 июня 2009 г.) № 1198-ЗТО «О регулировании отдельных правоотношений, связанных с выборами депутатов Тульской областной Думы» вообще отсутствует какая-либо структура. Представляется, что данные недостатки юридической техники требуют скорейшего устранения.

Необходимость продолжения работы по приведению законодательной основы защиты конституционного строя России в избирательном процессе в соответствие федеральному законодательству и дальнейшему повышению качества законодательства субъектов Российской Федерации о выборах определяется тем, что в законодательстве Российской Федерации до настоящего времени не предусмотрена уголовная или административная ответственность за принятие должностными лицами органов государственной власти субъектов Российской Федерации нормативных правовых актов, противоречащих Конституции Российской Федерации, федеральным конституционным и федеральным законам, повлекших за собой массовые нарушения прав и свобод человека и гражданина, угрозу единству и территориальной целостности Российской Федерации, безопасности Российской Федерации и ee обороноспособности, единству правового и экономического пространства Российской Федерации. В связи с изложенным, представляется целесообразным продолжить работу законодательных органов субъектов Российской Федерации по восполнению пробелов в правовом регулировании, устранению внутренних противоречий и противоречий федеральному законодательству. Большую роль в этом процессе должно сыграть активное использование предоставленного 
избирательным комиссиям законодательством субъектов Российской Федерации права законодательной инициативы в пределах своей компетенции.

Развитие подзаконной правовой основы обеспечения избирательного процесса в интересах защиты конституционного строя необходимо рассматривать с позиций федерального нормативного правового регулирования и нормативного правового регулирования на уровне субъектов Российской Федерации.

На федеральном уровне необходимо в первую очередь разрешить проблему распространения юрисдикции Правительства Российской Федерации на ряд министерств и ведомств, которыми непосредственно руководит Президент Российской Федерации. В настоящее время постановления Правительства Российской Федерации от 25 августа 1999 г. № 937, от 13 января 2000 г. № 32, от 5 сентября 2003 г. № 555, от 17 сентября 2007 года № 589 распространяют свою силу на подведомственные Президенту государственные органы, обеспечивающие защиту конституционного строя России в условиях выборов (ФСБ России, МВД России, ФМС России, Министерство по делам гражданской обороны, чрезвычайным ситуациям и ликвидации последствий стихийных бедствий, Министерство юстиции Российской Федерации, Министерство иностранных дел Российской Федерации, Министерство обороны Российской Федерации). Существует два варианта решения данной правовой проблемы:

Первый. Упразднение практики деления отраслевых органов исполнительной власти по подведомственности между Президентом и Правительством. В этом случае Правительство Российской Федерации сохраняет за собой регулирование взаимодействия компетентных государственных органов и учреждений с избирательными комиссиями.

Второй вариант означает, что подобное правовое регулирование должно осуществляться указами Президента Российской Федерации.

Кроме того, представляется, что юридическая сила издаваемых на федеральном уровне нормативных правовых актов о содействии избирательным комиссиям при подготовке и проведении выборов должна распространяться не только на федеральные, но и на региональные и муниципальные выборы.

Развитие подзаконного правового обеспечения избирательного процесса предполагает совершенствование ведомственной нормативной правовой основы 
субъектов защиты конституционного строя в избирательном процессе. С точки зрения юридической техники ведомственная нормативная правовая база, регулирующая участие компетентных государственных органов и учреждений в защите конституционного строя в условиях выборов, представляется недостаточно совершенной. Так, в принимаемых органами внутренних дел, прокуратуры и федеральной службы безопасности нормативных правовых актах не в полной мере отражены вопросы совместной деятельности по защите конституционного строя в избирательном процессе. В ведомственных приказах, как правило, не прописаны конкретные функции и полномочия создаваемых на период выборов организационных структур (оперативных штабов или оперативных групп). Не раскрывается суть организационных и иных мер обеспечения безопасности организации и проведения выборов. Не регулируются вопросы, связанные с защитой конституционного строя в ходе региональных и муниципальных избирательных кампаний. Ведомственные нормативные правовые акты имеют ограниченный срок действия и ориентированы преимущественно на конкретные избирательные кампании федерального уровня.

C учетом изложенного, было бы целесообразно разработать межведомственный нормативный правовой акт в рассматриваемой области, рассчитанный на неоднократное использование. Принятие подобного документа будет способствовать четкому разграничению компетенции субъектов защиты конституционного строя в избирательном процессе, укреплению стабильности и повышению эффективности правового обеспечения защиты конституционного строя России в условиях избирательных кампаний.

Нуждаются в конкретизации и нормотворческие полномочия ЦИК России. В Регламенте Центральной избирательной комиссии Российской Федерации отсутствуют виды нормативных правовых актов, которые может принимать Центральная избирательная комиссия Российской Федерации. Из числа нормативных правовых актов ЦИК России упоминаются только инструкции. При этом нормативный правовой характер, кроме инструкций Центральной избирательной комиссии, носят положения, регламенты и соглашения. Думается, что этот пробел правового регулирования требует восполнения. 
На уровне субъектов Российской Федерации весьма важной является подготовка и принятие нормативных правовых актов, касающихся вопросов участия органов государственной власти, муниципальных органов, правоохранительных органов в защите конституционного строя в условиях выборов. В качестве положительного примера можно привести упомянутые выше постановления высших должностных лиц субъектов Федерации о содействии избирательным комиссиям в организации и проведении выборов, где, в том числе детально регламентируется совместная деятельность избирательных комиссий и правоохранительных органов. Практику принятия подобных нормативных правовых актов высших должностных лиц субъектов Российской Федерации следовало бы распространить на всю территорию Российской Федерации.

Актуальным является вопрос о правомочиях избирательных комиссий субъектов Российской Федерации по регулированию взаимодействия с государственными органами и учреждениями (в том числе, с территориальными подразделениями федеральных органов исполнительной власти), действующими на территории субъектов Российской Федерации.

Качество правового обеспечения избирательного процесса определяет полноту реализации конституционного права граждан на участие в управлении делами общества и государства, степень доверия населения к власти и представительным органам, влияет на оценку международным сообществом состояния демократичности политической системы.

Представляется, что совершенствование законодательного и подзаконного обеспечения избирательного процесса в интересах защиты конституционного строя России позволит повысить эффективность защиты конституционного строя, будет способствовать демократизации и укреплению законности избирательного процесса.

\footnotetext{
4.2. Развитие иностранного (международного) и общественного контроля избирательного процесса в интересах защиты конституционного строя России
} 
Институт иностранного (международного) наблюдения за выборами изначально был создан для помощи территориям, управляемым по мандату $\mathrm{OOH}$, стремящимся добиться самоопределения ${ }^{1}$. Бывшие колонии нуждались в иностранных (международных) программах помощи и контроля при формировании демократических органов власти и защите прав человека. В дальнейшем данный институт подтвердил свою эффективность в обеспечении избирательного процесса и мирного развития на территориях сторон - бывших участников локальных военных конфликтов (Босния и Герцеговина, Камбоджа, Мозамбик, Сальвадор, Палестинская автономия). После крушения социалистического блока государств Совещание по безопасности и Сотрудничеству в Европе (СБСЕ - позднее ОБСЕ) приступило к реализации долгосрочной Программы выборов в странах «молодой демократии». В соответствии с Документом Копенгагенского совещания Конференции по человеческому измерению СБСЕ от 29 июня 1990 г. и решениями Парижской Хартии для новой Европы СБСЕ от 21 ноября 1990 г. в апреле 1991 г. было учреждено Бюро по свободным выборам (позднее - Бюро по демократическим институтам и правам человека (БДИПЧ)). Основной задачей созданной организации стало формирование традиций проведения свободных и демократических выборов в посткоммунистических государствах. Государства участники СБСЕ, подписавшие указанные международные правовые акты признали, что «присутствие наблюдателей как иностранных, так и национальных, может повысить авторитетность избирательного процесса для государств, в которых проводятся выборы». После Будапештской встречи на высшем уровне, состоявшейся 5-6 декабря 1994 г., на БДИПЧ была возложена роль организатора мониторинга за избирательным процессом и координатора миссий наблюдения, осуществляющих свою деятельность в области человеческого измерения под

\footnotetext{
1 Использование понятий «иностранное (международное) наблюдение», «иностранный (международный) наблюдатель» является устоявшейся законодательной формулой, о чем свидетельствует анализ пунктов 3,6 и 13 статьи 30 Федерального закона от 12 июня 2002 г. № 67-Ф3, пунктов 5 и 6 статьи 23, статьи 24 Федерального закона от 10 января 2003 г. № 19-Ф3, статьи 31 Федерального закона от 18 мая 2005 г. № 51-Ф3. Квазисинонимичность связана с тем, что данная категория наблюдателей имеет одинаковый правовой статус в избирательном процессе, что проявляется в аналогичном порядке направления, аккредитации, правомочиях, сроках деятельности, материально-финансовом обеспечении, основаниях отзыва аккредитации.
} 
эгидой ОБСЕ. В 1997 г. в Варшаве было принято Руководство по наблюдению за выборами ОБСЕ/ БДИПЧ. Каждое государство-участник, подписавшее документ, приняло на себя обязательства обеспечить присутствие как национальных наблюдателей, так и наблюдателей из любой страны - участницы на период проведения избирательной кампании.

Развитие международных избирательных стандартов и нормативных положений об иностранном (международном) наблюдении за выборами послужило в 1990-х гг. стимулом к активизации мониторинговой деятельности на выборах в странах Восточной, Юго-Восточной Европы, СНГ, Азии, Африки и Латинской Америки.

В России возможность осуществления иностранного наблюдения за выборами была впервые закреплена в Положении о статусе иностранных наблюдателей в период проведения выборов депутатов Федерального Собрания Российской Федерации в 1993 г., утвержденном Постановлением ЦИК России от 1 ноября 1993 г. После принятия Федеральных законов «О выборах Президента Российской Федерации» от 17 мая 1995 г. и «О выборах депутатов Государственной Думы Федерального Собрания Российской Федерации» от 21 июня 1995 г. статус иностранных наблюдателей получил законодательное закрепление. После ратификации Конвенции о стандартах демократических выборов, избирательных прав и свобод в государствах - участниках Содружества Независимых Государств Российская Федерация приняла на себя обязательства принимать наблюдателей от СНГ.

В страны «старой демократии» международные наблюдатели до 2002 г. вообще не направлялись, поскольку существовала презумпция «свободы и честности» проводимых там выборов. Но и после 2002 г. миссии наблюдателей БДИПЧ ОБСЕ в западных странах носят декоративный характер. Так, на выборы в конгресс США в 2002 году БДИПЧ прислало всего 18 наблюдателей, на итальянские и ирландские парламентские выборы - по 8 человек, на парламентские выборы в Великобритании в мае 2005 г. и парламентские выборы 
в Канаде в январе 2006 г. - 10 экспертов ${ }^{1}$. На выборы в ФРГ и Польше в 2005 г., в Венгрии в 2006 г. не было направлено ни одного наблюдателя. Для сравнения: за выборами в Государственную Думу Федерального Собрания Российской Федерации в 2003 г. наблюдали 1168 иностранных и международных наблюдателей, за «третьим туром» президентских выборов на Украине в декабре 2004 г. наблюдали 1300 краткосрочных наблюдателей. В Азербайджане в ноябре 2005 г. БДИПЧ разместило 500 международных наблюдателей ${ }^{2}$

Почему же миссии международного наблюдения за выборами в одном случае (США и страны ЕС) совсем не осуществляют наблюдение либо осуществляют его в весьма ограниченном формате, а в другом случае (в государствах СНГ) - становятся активным участником политического процесса в государстве пребывания и даже надгосударственным контрольно-надзорным органом в условиях избирательной кампании и после ее окончания?

Дело в том, что правилами БДИПЧ предусмотрено разделение стран на три группы: «страны устойчивой демократии», «страны новой демократии» и «страны, переходящие к демократии». Отнесение БДИПЧ государства к той или иной группе стран означает различный объем вмешательства международного сообщества в избирательный процесс (формат внешнего наблюдения) и различную свободу оценки результатов выборов. Формат «наблюдательныхх» миссий применяется БДИПЧ в отношении стран с недемократическим прошлым ${ }^{3}$. В частности, в «странах новой демократии» и «переходящих к демократии» допускается возможность не только наблюдать за выборами, но и право определить по собственному усмотрению количество наблюдателей, право выступать с публичными заявлениями о предварительных выводах наблюдателей до объявления официальных результатов выборов и разрешения судебных споров, право оценить выполнение государством всего комплекса международных

\footnotetext{
${ }^{1}$ См.: Рос. газ. 2007. 7 ноября.

${ }^{2}$ См.: Смирнов Ю. Электоральные манипуляции // Политический журнал. 2006. № 13. С. 58.

${ }^{3}$ Оценка «демократичности» того или иного государства осуществляется также Парламентской ассамблеей Совета Европы. Открытие процедуры мониторинга за состоянием прав человека по линии ПАСЕ означает косвенное признание государства «новой демократией» или страной, «переходящей к демократии».
} 
обязательств ${ }^{1}$. Для «стран устойчивой демократии» существуют т.н. «оценочные» миссии. Они лишь помогают властям в решении различных технических проблем, связанных с выборами.

Африканские страны, государства СНГ и Латинской Америки, по мнению БДИПЧ ОБСЕ, к числу «стран устойчивой демократии» не относятся. В связи с этим к ним, как правило, и применяется соответствующий формат наблюдения, методология мониторинга выборов и оценки их результатов.

При решении вопроса о соответствии международных обязательств России интересам защиты ее конституционного строя необходимо учитывать «двойные» стандарты, применяемые отдельными странами Запада в оценке демократичности и свободы проведения выборов.

Весомый вклад в совершенствование методологии иностранного и международного наблюдения за выборами, в выработку единых критериев оценки избирательного процесса для всех государств-участников ОБСЕ могло бы внести принятие документа «Копенгаген-плюс», концепция которого обсуждается в рамках ОБСЕ уже несколько лет.

Институт иностранного (международного) наблюдения в его современном виде все чаще приходится рассматривать не как помощь в проведении демократических выборов и независимый контроль качества избирательных процедур, а как орудие политической борьбы и вмешательства во внутренние дела суверенных государств, используемое США в целях формирования управляемой извне системы органов государственной власти и управления. Получившая распространение практика выдвижения иностранными (международными) наблюдателями незаконных требований о непризнании итогов выборов, распространения заведомо ложной информации, связанной с подготовкой и проведением выборов, подрывает доверие граждан к собственному государству, способствует осложнению общественно-политической обстановки и оказывает деструктивное воздействие на конституционный строй.

${ }^{1}$ См.: Чуров B.E. Суверенная демократия и выборы // Рос. газ. 2007. 30 марта. Необходимо отметить, что в отличие от наблюдателей ОБСЕ, миссии наблюдателей ООН играют в ходе избирательной кампании только посредническую роль и своего суждения относительно процесса или итогов выборов не высказывают. 
Спровоцированные таким образом затяжные политические кризисы всерьез угрожают нормальному функционированию демократических институтов в «наблюдаемой» стране.

Учитывая, что дестабилизация политической ситуации в государстве, инспирирование сепаратистских настроений и межнациональных обострений, утрата политической независимости противоречат интересам Российской Федерации, в целях защиты ее конституционного строя в избирательном процессе предлагается реализовать следующие меры реформирования института иностранного (международного) наблюдения за выборами ${ }^{1}$ :

- предложить ОБСЕ отказаться от формирования миссий наблюдения на непрофессиональной основе (наблюдатели должны быть специалистами в области конституционного или избирательного права). Процедура аккредитации иностранного и международного наблюдателя должна предусматривать обязательную тестовую проверку на знание национального избирательного права и процесса ${ }^{2}$. Повысить профессионализм мониторинговых миссий могло бы преимущественное приглашение наблюдателей, представляющих избирательные комиссии иностранных государств (в частности, наблюдателей Ассоциации организаторов выборов стран Европы, включающей представителей 20 центральных избирательных органов европейских государств или наблюдателей Организации Американских государств);

- ввести новый порядок формирования совместных миссий наблюдения за выборами, основанный на членстве (участии) государства в конкретных международных организациях;

- переориентироваться на приоритетное участие России в долгосрочных мониторинговых миссиях и в основных командах БДИПЧ ОБСЕ, а также придерживаться справедливого географического принципа формирования миссий

1 О совершенствовании опыта международного наблюдения за выборами и референдумами см. также: Вешняков A.A. Новые избирательные технологии и проблемы наблюдения за выборами // Журнал о выборах. 2005. № 3. С. 54-59; Лысенко В.И., Евланов И.А. Выборы - по демократическим стандартам // Журнал о выборах. 2005 . № 3. С. 58-59; Лысенко В.И., Евланов И.А. Новый шаг в развитии международных избирательных стандартов // Журнал о выборах. 2008. № 6. С. 8-16; Вавилов С.В. О совершенствовании системы международного сотрудничества в области демократических выборов // Журнал о выборах. 2008. № 6. С. 17-19; Иванченко А.B. Национальные выборы и принципы международного наблюдения // Журнал о выборах. 2008. № 5. С. $43-47$.

${ }^{2}$ См.: Вешняков А.А. // Там же. С. 59. 
наблюдения. Как показывает практика, данные с избирательных участков интерпретируются долгосрочными наблюдателями и основными командами БДИПЧ ОБСЕ, которые и принимают окончательное решение по итогам избирательной кампании. Необходимо изменить существующую практику формирования миссий наблюдения, в соответствии с которой определение количественного и персонального состава групп наблюдения является прерогативой БДИПЧ/ОБСЕ;

- стимулировать активизацию совместных мониторинговых процедур с государствами СНГ на базе Международного института мониторинга развития демократии, парламентаризма и соблюдения избирательных прав граждан государств - участников Межпарламентской Ассамблеи СНГ;

- рекомендовать ОБСЕ отказаться от краткосрочных миссий наблюдения за выборами. Нередко участники этих миссий не знают законодательства страны пребывания, не имеют представления о национальной процедуре голосования и подведения итогов голосования, о порядке передачи данных об итогах голосования в вышестоящие комиссии;

- отказаться от предварительных заключений международных миссий наблюдения о состоявшихся выборах. Эти заключения носят политически ангажированный характер и препятствуют подготовке взвешенных, отличающихся по содержанию итоговых отчетов, выражающих позицию не только руководства миссии, но и направляющей международной организации в целом. Итоговый отчет миссии должен приниматься большинством ее состава;

- осуществлять нормативно-правовое регулирование деятельности международных наблюдателей в интересах защиты конституционного строя. Это предполагает:

а) на законодательном уровне: разработку нормативного правового акта, детально регулирующего процедуры иностранного и международного наблюдения на территории Российской Федерации, порядок и основания приглашения наблюдателей. 
Важное значение имеет регулирование правового положения наблюдателей. Учитывая, что в действующем российском законодательстве отсутствуют нормы, предусматривающие ответственность иностранных (международных) наблюдателей, главу 5 Кодекса Российской Федерации об административных правонарушениях представляется целесообразным дополнить ст. 5.25 .1 «Нарушение иностранным (международным) наблюдателем порядка наблюдения за подготовкой и проведением выборов, референдума» 1 .

В этом случае имеющиеся в законодательстве РФ положения об административной ответственности за нарушение прав иностранных (международных) наблюдателей (ст. 5.6 КОАП РФ) будут логично дополняться нормами об ответственности иностранных (международных) наблюдателей за нарушение порядка наблюдения за подготовкой и проведением выборов.

б) на уровне указов Президента Российской Федерации:

на период каждой избирательной кампании федерального уровня ввести по согласованию с МИД России нормативное квотирование количества иностранных (международных) наблюдателей (как показывает практика, слишком большое число наблюдателей затрудняет работу избирательных комиссий, голосование, подсчет голосов и в ряде случаев становится фактором давления на самих избирателей). Кроме того, окончательное решение о количестве наблюдателей должно приниматься принимающей, а не направляющей стороной.

в) на уровне ЦИК России представляется целесообразным детализировать существующий порядок аккредитации и отзыва аккредитации наблюдателей.

На наш взгляд, следовало бы отказаться от аккредитации лиц и организаций, имеющих политические, экономические, идеологические и иные интересы в Российской Федерации, а также лиц, в отношении которых было принято решение об отзыве аккредитации за нарушение законодательства и принципов международного права. Основанием для отказа в аккредитации иностранного (международного) наблюдателя или представителя средств массовой информации иностранного государства должны служить сведения о

${ }^{1}$ См. Приложение. 
применении к иностранному (международному) наблюдателю или представителю средств массовой информации иностранного государства депортации или административного выдворения за пределы Российской Федерации, сведения о принятии решения о нежелательности пребывания (проживания) в Российской Федерации, сведения о привлечении в Российской Федерации указанных лиц к уголовной или административной ответственности либо к ответственности за совершение налоговых правонарушений. Данные ограничения соответствуют положениям Декларации принципов международного наблюдения (OOH, 27 октября 2005 г.). Предлагается нормативно закрепить статус стажеровнаблюдателей с ограниченными полномочиями по наблюдению и распространять его на лиц, не имеющих опыта наблюдения за выборами.

Если реализация предложенных законодательных новелл не приведет к изменению предвзятого характера деятельности иностранных и международных миссий наблюдения, представляется целесообразным постепенно отказаться от навязанного БДИПЧ/ОБСЕ Российской Федерации существующего формата наблюдения за выборами и перейти к принципиально иной концепции наблюдения за выборами.

Возможным выходом из сложившейся ситуации могло бы стать заключение Российской Федерацией двусторонних договоров о взаимном наблюдении за выборами с заинтересованными государствами - участниками ОБСЕ и активизация совместных мониторинговых процедур с государствами Содружества - участниками ОБСЕ. Предполагается, что вместо наблюдателей БДИПЧ/ОБСЕ, ПАСЕ, Европарламента, Парламентских ассамблей ОБСЕ и НАТО на выборы в Российскую Федерацию будут приглашаться наблюдатели, представляющие государства ОБСЕ, с которыми заключены соответствующие договоры о мониторинге, представители Шанхайской Организации Сотрудничества, Межпарламентской ассамблеи государств - участников Содружества Независимых Государств, Парламентского Собрания Союза Беларуси и России. Формирование подобной концепции международного наблюдения за выборами, не ассоциирующейся с «двойными стандартами», будет 
способствовать восстановлению политического баланса сил на международной арене, повысит престиж и авторитет Российской Федерации. Если же дальнейшая практика международных отношений покажет, что существующий формат дискриминационной мониторинговой деятельности ОБСЕ уступит место новым подходам, основанным на объективном наблюдении за выборами, реальной защите прав человека и неукоснительном соблюдении норм международного права, Российская Федерация вправе вернуться к полноценному взаимовыгодному сотрудничеству.

Формирование новой концепции иностранного (международного) наблюдения за выборами может быть двухэтапным.

На первом этапе предполагается укрепление системы независимых избирательных комиссий, приоритетное развитие национальных институтов гражданского общества («внутренней системы» наблюдения за выборами) и частичный отказ от существующего формата внешнего наблюдения, означающий отказ от приглашения «наблюдательных» миссий и отказ от приглашения в качестве наблюдателей миссий государств, не признающих внешнее наблюдение за выборами.

На втором этапе предполагается привести ратифицированные Российской Федерацией международные договоры в сфере организации и проведения выборов и связанные с ними обязательства России в соответствие с интересами защиты конституционного строя. Эту работу следует проводить как в отношении не вступивших в законную силу на территории Российской Федерации международных правовых актов, так и в отношении действующих международных договоров.

Как показывает опыт развитых стран, политика суверенного государства должна быть направлена на замещение иностранных и международных наблюдателей наблюдателями из числа собственных граждан. Развитие национальных институтов гражданского общества означает развитие общественного контроля за выборами со стороны политических партий, 
свободных СМИ (в том числе общественного вещания), общественных приемных, общественных палат, молодежных и иных общественных организаций.

В связи с введением пропорциональной избирательной системы на выборах депутатов Государственной Думы Федеральный закон «О выборах депутатов Государственной Думы Федерального Собрания Российской Федерации» сохранил право направлять своих представителей в качестве наблюдателей за ходом голосования и подсчета голосов только за политическими партиями, зарегистрировавшими федеральные списки кандидатов. Данное решение законодателя представляется ошибочным. В отличие от партийных наблюдателей непартийный мониторинг проводится гражданами, не заинтересованными в результатах выборов. Кроме того, развитие системы независимого общественного наблюдения за выборами могло бы способствовать дальнейшей демократизации политической системы Российской Федерации ${ }^{1}$.

В соответствии с пунктом 9 статьи 30 Федерального закона от 12 июня 2002 г. № 67-ФЗ наблюдатели вправе:

- знакомиться со списками избирателей, участников референдума, реестром выдачи открепительных удостоверений, находящимися в комиссии открепительными удостоверениями, реестром заявлений (обращений) о голосовании вне помещения для голосования;

- находиться в помещении для голосования соответствующего избирательного участка, участка референдума в день голосования, а также в дни досрочного голосования в любое время;

- наблюдать за выдачей бюллетеней избирателям, участникам референдума;

- присутствовать при голосовании избирателей, участников референдума вне помещения для голосования;

- наблюдать за подсчетом числа граждан, внесенных в списки избирателей, участников референдума, бюллетеней, выданных избирателям, участникам референдума, погашенных бюллетеней; наблюдать за подсчетом голосов

${ }^{1}$ Соответствующий законопроект был внесен в Государственную Думу 30 июня 2006 г. (проект № 315336 4), однако до сих пор не рассмотрен. В 1995 г. было подготовлено несколько законопроектов об общественном контроле за проведением выборов, открытости и гласности подведения итогов голосования. Данные правовые акты также не были приняты. 
избирателей, участников референдума на избирательном участке, участке референдума на расстоянии и в условиях, обеспечивающих им обозримость содержащихся в бюллетенях отметок избирателей, участников референдума; знакомиться с любым заполненным или незаполненным бюллетенем при подсчете голосов избирателей, участников референдума; наблюдать за составлением комиссией протокола об итогах голосования и иных документов;

- обращаться к председателю участковой комиссии, а в случае его отсутствия к лицу, его замещающему, с предложениями и замечаниями по вопросам организации голосования;

- знакомиться с протоколами соответствующей комиссии, нижестоящих комиссий об итогах голосования, о результатах выборов, референдума и приложенными к ним документами, получать от соответствующей комиссии заверенные копии указанных протоколов;

- носить нагрудный знак с обозначением своего статуса и указанием своих фамилии, имени и отчества, а также фамилии, имени и отчества зарегистрированного кандидата или наименования избирательного объединения, общественного объединения, направивших наблюдателя в комиссию;

- обжаловать действия (бездействие) комиссии в вышестоящую комиссию, избирательную комиссию субъекта Российской Федерации, Центральную избирательную комиссию Российской Федерации или в суд;

- присутствовать при повторном подсчете голосов избирателей, участников референдума в соответствующих комиссиях.

Обязательными участниками общественного контроля за выборами являются представители СМИ. Осуществляя информационное освещение подготовки и проведения выборов, представители СМИ наделены правами:

- присутствовать на заседаниях комиссий;

- знакомиться с протоколом участковой комиссии об итогах голосования, а также с протоколами иных комиссий об итогах голосования, о результатах выборов, референдума, в том числе составляемыми повторно, получать от 
соответствующей комиссии копии указанных протоколов и приложенных к ним документов;

- присутствовать на агитационных мероприятиях, освещать их проведение;

- находиться в помещении для голосования в день голосования, в дни досрочного голосования, а также производить фото- и видеосъемку.

Важная роль в обеспечении законности избирательного процесса принадлежит общественным приемным полномочного представителя Президента Российской Федерации. Они оказывают гражданам содействие при рассмотрении их обращений в территориальные подразделения федеральных органов исполнительной власти и органы местного самоуправления, проводят мероприятия по правовому просвещению граждан, в том числе, в сфере избирательного права и процесса.

На базе общественных приемных может быть организован конструктивный диалог региональных и местных властей с представителями партий, движений, общественных объединений, молодежных и ветеранских организаций, объединений научной и творческой интеллигенции по проблемам подготовки и проведения выборов. Такая деятельность в форме общественного Совета при руководителе общественной приемной может стать элементом достижения согласия и средством противодействия политическому экстремизму и нагнетанию ксенофобии в электоральных процессах ${ }^{1}$.

Ключевым элементом системы общественного контроля избирательного процесса является контроль за проведением выборов и обеспечением конституционных прав участников избирательного процесса, осуществляемый Общественной палатой Российской Федерации (далее - Общественной палатой). В условиях выборов Общественная палата способствует защите прав и свобод граждан и общественных объединений, а также обеспечивает общественный контроль за деятельностью федеральных органов исполнительной власти, органов исполнительной власти субъектов Российской Федерации и органов местного

\footnotetext{
${ }^{1}$ См.: Волков В.П., Дамаскин О.В., Шапиев С.М. Некоторые проблемы и пути их решения для обеспечения законности избирательного процесса в Российской Федерации. М.: РЦОИТ, 2009. С. 46.
} 
самоуправления. Общественная палата проводит экспертизы проектов нормативных правовых актов, затрагивающих конституционные (в том числе, избирательные) права, свободы и законные интересы граждан и общественных объединений; выдвигает гражданские инициативы в сфере правозащитной деятельности; осуществляет контроль за соблюдением свободы слова в средствах массовой информации; вырабатывает рекомендации органам государственной власти в области государственной поддержки общественных объединений и объединений граждан, деятельность которых направлена на развитие гражданского общества в России; проводит слушания и принимает участие в работе различных конференций, совещаний и других общественно-политических мероприятиях. К сожалению, необходимо выделить ограниченность контрольных полномочий Общественной палаты, поскольку в соответствии с частью 1 статьи 17 Федерального закона от 4 апреля 2005 г. (в ред. от 25 декабря 2008 г.) № 32-Ф3 «Об Общественной палате Российской Федерации» ее решения носят для государственных органов и должностных лиц рекомендательный характер.

Выборные кампании последних лет свидетельствуют о возможности создания эффективного механизма контроля избирательного процесса со стороны общественных организаций и объединений избирателей. Так, на федеральных выборах 2007-2008 гг. под эгидой Российского фонда свободных выборов была развернута «горячая линия» связи с избирателем. Организаторам «горячей линии» удалось создать систему общественного контроля, которая не позволила целому ряду иностранных неправительственных организаций дестабилизировать общественно-политическую ситуацию вокруг выборов, подпитывать зарубежных критиков России негативной информацией, лишила их возможности развернуть свою работу в тех масштабах, которые противоречили бы национальным интересам Российской Федерации. Российские граждане, негосударственные организации и международное сообщество убедились, что в России есть общественные институты, которые могут не просто взаимодействовать с официальными властями и с организаторами выборов, но и добиваться желаемых результатов. 
Было создано 38 пунктов «горячей линии» по всей Российской Федерации. За время их работы поступило около 32 тысяч обращений граждан. В день голосования поступило свыше 10 тысяч звонков, факсов и посланий по электронной почте. На каждом избирательном участке был информационный лист с координатами пунктов «горячей связи». В день голосования в Информационном центре ЦИК России был размещен общественный мобильный пункт Российского фонда свободных выборов, оснащенный видеоинтернетом связи с пунктами «горячей линии». Следует отметить, что средства массовой информации активно использовали возможности этого новшества. Состоялось 38 прямых выходов в телеэфир, 314 информационных сюжетов на телевидении, 250 сообщений информационных агентств и публикаций ${ }^{1}$.

Эта форма работы общественных организаций с гражданами оказалась востребованной на региональных и муниципальных выборах 2009-2010 гг.

Представляется, что создание сети общественных пунктов «горячей линии» связи с избирателями призвано содействовать проведению свободных, справедливых и прозрачных выборов. Для достижения поставленной цели организаторы общественной «горячей линии» во взаимодействии с Общественной палатой Российской Федерации, Координационным советом по защите избирательных прав граждан, общественными палатами (советами) субъектов Российской Федерации и другими неправительственными организациями, по согласованию с ЦИК России и избирательными комиссиями субъектов Российской Федерации разработали единую методику получения, обработки обращений граждан, а также механизм реагирования на них. Для повышения эффективности нормативно-правовой и экспертно-консультативной практики пунктов общественной «горячей линии» к работе на них были привлечены опытные специалисты в области избирательного права и выборных технологий, а в качестве дежурных операторов: на Центральном пункте - студенты МГУ,

\footnotetext{
${ }^{1}$ См.: Волков В.П., Дамаскин О.В., Шапиев С.М. Указ. соч. С. 130-131.
} 
МГЮА и активисты движения «Молодые юристы России», в регионах - студенты юридического профиля ведущих ВУЗов Российской Федерации ${ }^{1}$.

При открытии сети пунктов общественной «горячей линии», прежде всего, учитывались неангажированность и равноудаленность организаций и учреждений от политических структур, их неаффилированность с какой-либо политической партией или подконтрольной ей структурой, авторитетность организаций в глазах общественности, относительная их самостоятельность в отношениях с органами государственной власти и местного самоуправления, отсутствие к организациям претензий со стороны правоохранительных и налоговых органов. Именно благодаря неукоснительному соблюдению указанных принципов «горячая линия» и смогла выполнить роль независимого центра общественного мониторинга соблюдения законных прав и интересов избирателей ${ }^{2}$.

Анализ актуальных проблем развития иностранного (международного) и общественного контроля избирательного процесса свидетельствует о том, что в современной России востребованы новые подходы к объективному иностранному (международному) и национальному наблюдению за выборами, основанные на отказе от предвзятого и прогнозируемого характера деятельности миссий наблюдения, реальной защите прав человека, неукоснительном соблюдении норм избирательного права и совершенствовании эффективного общественного контроля организации и проведения выборов. В этих целях осуществляется постоянное правовое образование и повышение профессионализма организаторов выборов, наблюдателей и представителей СМИ, обучение кандидатов, их доверенных лиц, уполномоченных представителей политических партий квалифицированному ведению избирательных кампаний. Существенный вклад в совершенствование контроля избирательного процесса вносит деятельность

${ }^{1}$ См. Итоги работы общественной «горячей линии» связи с избирателями в Единый день голосования в субъектах Российской Федерации 1 марта 2009 г. М.: Общественная палата Российской Федерации, Российский Фонд свободных выборов, Координационный совет по защите избирательных прав граждан, 2009. С. 4.

2 См. «Горячая линия» связи с избирателями как эффективная форма общественного контроля за соблюдением избирательных прав граждан. Итоговый доклад. М.: Общественная палата Российской Федерации, Российский Фонд свободных выборов, Координационный совет по защите избирательных прав граждан, 2008. С. 5 . 
институтов гражданского общества (независимых СМИ, общественных организаций и объединений избирателей).

\section{3. Обеспечение конституционно-правовых гарантий легитимации избирательного процесса в интересах защиты конституционного строя России}

Государственная власть не может рассчитывать на длительное существование и эффективную деятельность, полагаясь только на принуждение. Необходимо добровольное согласие большинства законопослушного населения. При этом основной предпосылкой добровольного согласия является уверенность народа в том, что представители власти с полным основанием занимают свои посты, что они вырабатывают и претворяют в жизнь свои решения в сфере законных жизненно важных интересов общества. Там, где легитимность власти не бесспорна, воцаряется беззаконие и опасность революционных потрясений ${ }^{1}$.

Признание власти легитимной осуществляется в результате ее легитимации. Процесс легитимации публичной власти можно структурно представить в виде легитимации избирательного процесса и легитимации назначения должностных лиц различного уровня. Легитимация избирательного процесса включает в себя законность прохождения выборов, а также принятие обществом сформированной в условиях избирательной кампании политической власти, готовность выполнять ее требования. Легитимация назначения должностных лиц предполагает авторитет кандидатуры, ее поддержку большинством и желание подчиненных следовать указаниям назначенного лица.

Легитимация избирательного процесса имеет два аспекта: внутренний и внешний. Внутренний аспект означает признание населением государства результатов выборов представительных органов власти. Внутренний аспект легитимации неразрывно связан с политической активностью, развитым правосознанием избирателей, демократичностью законодательства о выборах, законностью избирательных действий и процедур, популярностью кандидатов в депутаты или на выборные должности, авторитетом избирательных комиссий в

\footnotetext{
${ }^{1}$ См.: Шаран П. Сравнительная политология. Ч. 1. М., 1992. С. 113-114.
} 
глазах общества, свободой массовой информации, независимостью политических партий и кандидатов от государственных и муниципальных органов. Внутренняя легитимация избирательного процесса является главным условием политической стабильности и незыблемости конституционного строя. Готовность граждан поддерживать и выполнять требования представительной власти определяет ее жизнеспособность и эффективность реализации проводимого избранными должностными лицами политического курса. Правящие политические силы заинтересованы в удержании государственной власти с помощью завоевания и сохранения доверия населения. В связи с этим внутренний аспект легитимации избирательного процесса имеет определяющее значение для защиты конституционного строя России ${ }^{1}$.

Внешний аспект легитимации избирательного процесса обусловлен признанием результатов выборов иностранными (международными) мониторинговыми миссиями, а также поддержкой сформированной в условиях избирательной кампании политической власти со стороны уполномоченных государственных органов иностранных государств. Внешняя легитимация избирательного процесса может зависеть не только от политической активности населения, законности избирательных действий и процедур, но и от политической ориентации основных претендентов на выборные должности, сложившихся отношений руководства страны с США, Евросоюзом, ключевыми военнополитическими блоками, экономической роли государства в мировой и региональной экономике ${ }^{2}$. Представляется, что внешняя легитимация избирательного процесса, подменяющая волеизъявление граждан, подрывает народный и государственный суверенитет. Политическая власть, опирающаяся главным образом на внешнюю поддержку, не имеет долгосрочных перспектив и устойчивости. Органы публичной власти, образованные в ходе «управляемых»

1 См.: Дамаскин О.В. Легитимация результатов избирательного процесса и формирования органов государственной власти в Российской Федерации // Современное право. 2008. № 2. С. 19-24; Дамаскин О.В. Легитимация результатов избирательного процесса в Российской Федерации // Журнал о выборах. 2008. № 3. С. 14-19; Склифус С.В. Выборы как один из основополагающих принципов легитимации государственной власти в Российской Федерации // Правовая политика и правовая жизнь. 2008. № 3. С. 77-81.

${ }^{2}$ См.: Малиновский В.А. Международное наблюдение за выборами: обеспечение объективности или правовая основа для политических манипуляций? // Конституционное и муниципальное право. 2006. № 6. С. 42-47; Борисов И.Б. Проблемы международной легитимации выборов // Право и политика. 2006. № 10. С. 79-86. 
избирательных кампаний при вмешательстве иностранных государств и международных организаций, выражают, в первую очередь, интересы метрополий, марионетками которых они и являются.

Исходя из наличия двух аспектов легитимации избирательного процесса, соответствующих субъектов и условий легитимации возможны 4 основные модели легитимации представительной власти:

1) избранные органы власти внутренне и внешне легитимны;

2) избранные органы власти внутренне легитимны, внешне нелигитимны;

3) избранные органы власти внутренне нелигитимны, внешне легитимны;

4) избранные органы власти внутренне и внешне нелигитимны.

Наиболее стабильной и долговременной является политическая система, в рамках которой избранные органы власти внутренне и внешне легитимны (признаны внутренним и внешним субъектами легитимации). Наименее стабильной и кратковременной по продолжительности существования политическая система, в которой отсутствуют внутренняя и внешняя легитимность.

В качестве примера можно рассмотреть парламентские выборы в Таиланде, состоявшиеся в декабре 2007 г. Иностранные (международные) и национальные мониторинговые миссии не признали результаты выборов в связи с массовыми фальсификациями. Регулярные демонстрации протеста многочисленных противников победившей на выборах «Партии народной власти», решение Конституционного суда Таиланда о роспуске правящей партии в связи с фальсификацией результатов выборов привели к смене руководства страны и трансформации политической системы.

Две смешанные модели легитимации представительной власти характеризуются наличием только одного (внутреннего или внешнего) субъекта легитимации. Устойчивость политических систем, основанных на смешанных моделях легитимации власти, зависит от ряда условий: уровня жизни, традиций, 
психологии, правосознания населения; коррумпированности государственного аппарата и органов местного самоуправления; расстановки политических сил внутри страны; наличия военно-политических союзников регионального и глобального масштаба; объемов финансовой поддержки политического режима внутри страны и за ее пределами.

Примером смешанной модели легитимации представительной власти, в рамках которой избранные органы власти внутренне легитимны, а внешне нелигитимны, может служить Австрия после успешного участия в парламентских выборах 2000 г. националистической политической партии «Свобода». Формирование коалиции с участием партии «Свобода» повлекло за собой санкции 14 государств EC (прекращение официальных контактов с Правительством Австрии, технический уровень контактов с послами Австрии, бойкот австрийских кандидатов на должности в международных организациях).

Аналогичная модель легитимации представительной власти складывалась в течение длительного времени в Республике Беларусь. Соединенные Штаты Америки, Евросоюз, Совет Европы, Европарламент и ОБСЕ регулярно не признавали результаты национальных выборов в Республике Беларусь (выборов Президента 2001 и 2006 гг., выборов членов Совета Республики и депутатов Палаты представителей Национального Собрания Республики Беларусь 2000, 2004 и 2008 гг.) и применяли ограничительные меры политического и экономического характера в отношении Республики Беларусь.

Модель легитимации представительной власти, основанная на внешней легитимности, была сформирована в Афганистане в результате президентских выборов 2004 и 2009 гг., парламентских выборов 2005 г.

Характерными являются выборы Президента Афганистана 2009 г., сопровождавшиеся массовыми фальсификациями избирательных документов и результатов выборов. Прошедшие выборы не являлись свободными, справедливыми и прозрачными. Около 30\% избирательных участков не функционировали в связи с угрозами обеспечения безопасности избирателей, ракетными обстрелами, взрывами и террористическими атаками боевиков 
Талибана. В северных и восточных провинциях явка избирателей была критически низкой. Итоги голосования были официально аннулированы на 447 избирательных участках. 15 из 18 кандидатов в Президенты Республики Афганистан заявили о существенном искажении народного волеизъявления и своем отказе признать результаты состоявшихся выборов. Тем не менее, учитывая слабые экономические и военно-политические возможности правительства Афганистана, последовательную реализацию афганской политики в рамках внешнеполитической стратегии США, необходимость нормализации обстановки в стране, примирения наркоторговцев, боевиков Талибана, полевых командиров радикальных группировок и политических функционеров режима Хамида Карзая, вопрос внешнего признания результатов выборов и легитимации существующей власти в Афганистане носит для руководства США и Евросоюза принципиальный характер. Поэтому выборы, состоявшиеся в Афганистане, были признаны и поддержаны Администрацией Соединенных Штатов и их союзниками.

Следует различать понятия «легитимность» и «легальность» публичной власти ${ }^{1}$. Понятие легитимности носит оценочный и политический характер, легальность же предполагает формально-юридическую характеристику публичной власти. Государственная власть, даже не популярная, как правило, является легальной. В то же время она может быть нелегитимной, то есть не приниматься народом, несмотря на свое монопольное право издавать законы и использовать их как орудие организованного принуждения. Легитимность публичной власти означает социальное признание ее права на руководящую роль в обществе ${ }^{2}$.

Наиболее распространены две основные точки зрения на критерий легитимности: либеральная и прагматическая. Либеральный взгляд на легитимность заключается в том, что следует признавать только такую власть, которая сформировалась в результате демократических процедур. С

\footnotetext{
1 Подробней см: Чиркин B.E. Легализация и легитимация государственной власти // Государство и право. 1995. № 8. С. 65-73.

${ }^{2}$ См.: Волков В.П., Дамаскин О.В., Шапиев С.М. Некоторые проблемы и пути их решения для обеспечения законности избирательного процесса в Российской Федерации. М.: РЦОИТ, 2009. С. 162.
} 
прагматической точки зрения главное в проблеме легитимности власти - это не процедура ее формирования, а способность власти владеть ситуацией в обществе, поддерживать его в состоянии стабильности, действовать эффективно ${ }^{1}$.

Основой легитимности политической власти служит добровольное подчинение законам, рассмотрение власти как авторитетной для индивида инстанции. Легитимность власти нарушается, если она неспособна следовать своим собственным нормам. Поэтому легальность публичной власти, выражающаяся в ее способности оперировать и руководствоваться законами, служит базой легитимности власти ${ }^{2}$.

Легитимность - это не только законность данной власти с формальноюридической точки зрения, но и явление социально-психологическое, состоящее в принятии обществом данной политической власти или, как минимум, пассивном повиновении ей ${ }^{3}$. По мнению А.И. Демидова, смысл легитимности политической власти заключается в принятии ее теми людьми, на которые она распространяется, в признании ими ее права управлять и в их согласии подчиняться ${ }^{4}$. Так, вновь возникающие политические режимы (вследствие революций, военных переворотов и т.п.) могут стать легитимными, если обеспечат себе поддержку значительной части общества.

Одной из важнейших составляющих легитимности публичной власти является безопасность. Население поддерживает ту политическую систему и организацию власти, в рамках которых оно чувствует себя защищенным. Как справедливо отмечает А.Г. Бедов, легитимная политическая власть упорядочивает общественные отношения, придает «определенность направлениям деятельности властных структур, постоянство нормативов, привычность типов поведения» 5 . Политическая власть, утверждающая в обществе такие качества легитимности, как легальность, безопасность, порядок, приобретает авторитет - люди

\footnotetext{
${ }^{1}$ См.: Макеев А.В. Политология. М.: Академия ФСБ России, 2009. С. 184-185.

${ }^{2}$ См. Политология для юристов / Под ред. Н.И. Матузова и А.В. Малько. М.: Юристъ, 2002. С. 64-65.

${ }^{3}$ См.: Волков В.П., Дамаскин О.В., Шапиев С.М. Указ. соч. С. 162.

${ }^{4}$ См. Политология для юристов / Под ред. Н.И. Матузова и А.В. Малько. М.: Юристъ, 2002. С. 64.

${ }^{5}$ См.: Бедов А.Г. Политология. М., 1994. С. 207.
} 
добровольно передают ей свои властные полномочия, соглашаются подчиняться, чувствуют сопричастность властным действиям и способствуют им. Такая власть становится суверенной, обладающей способностью принимать решения, которые не могут быть пересмотрены никаким иным органом или организацией, кроме принявшего их ${ }^{1}$.

Неспособность публичной власти осуществлять свои полномочия, неэффективность реализации функций государства приводят к постепенному ограничению и утрате суверенитета, подрывают конституционный строй.

В рамках обеспечения легитимации избирательного процесса существенное значение приобретает система соответствующих конституционно-правовых гарантий².

Конституционно-правовые гарантии легитимации избирательного процесса представляют собой совокупность условий и средств, обеспечивающих законность прохождения выборов, а также принятие обществом сформированной в условиях избирательной кампании политической власти. Содержанием конституционно-правовых гарантий легитимации избирательного процесса являются закрепленные в Конституции Российской Федерации, федеральных конституционных и федеральных законах права, а также правила, обеспечивающие возможность реализации и защиты конституционных прав и свобод участников выборов, соблюдения избирательных процедур, осуществления демократических принципов функционирования избирательной системы Российской Федерации.

В конституционном законодательстве упоминается только один из видов конституционно-правовых гарантий легитимации избирательного процесса гарантии реализации основных избирательных прав граждан Российской Федерации.

\footnotetext{
${ }^{1}$ См. Политология для юристов / Под ред. Н.И. Матузова и А.В. Малько. М.: Юристъ, 2002. С. 70.

${ }^{2}$ См.: Бровченко B.H. Гарантии избирательных прав граждан Российской Федерации // Право и государство: теория и практика. 2003. № 12. С. 25-26; Артеменко Т.А. Гарантии избирательных прав граждан // Юридические науки. 2004. № 5. С. 56-58; Линник Л. Система юридических гарантий избирательных прав граждан Российской Федерации // Право и жизнь. 2002. № 44. С.95-103; Волков В.П., Дамаскин О.В., Шапиев С.М. Некоторые проблемы и пути их решения для обеспечения законности избирательного процесса в Российской Федерации. М.: РЦОИТ, 2009. C. 161.
} 
Пункт 11 статьи 2 Федерального закона от 12 июня 2002 г. № 67-Ф3 определяет гарантии избирательных прав и права на участие в референдуме как установленные Конституцией Российской Федерации, законом, иным нормативным правовым актом условия, правила и процедуры, обеспечивающие реализацию избирательных прав и права на участие в референдуме граждан Российской Федерации. Предложенная в данном Федеральном законе классификация гарантий избирательных прав (гарантии прав граждан при регистрации (учете) избирателей, составлении списков избирателей, образовании избирательных округов и участков; гарантии прав граждан при выдвижении и регистрации кандидатов; гарантии прав граждан на получение и распространение информации о выборах; гарантии прав граждан при организации и осуществлении голосования, подсчете голосов избирателей, установлении результатов выборов и их опубликовании) имеет очевидные недостатки. Во-первых, она не охватывает ряд стадий избирательного процесса (назначение выборов, формирование избирательных комиссий, финансирование, повторное голосование, повторные и дополнительные выборы). Во-вторых, она не способна отразить весь спектр общественных отношений, связанных с обеспечением законности избирательного процесса и защитой конституционного строя в условиях выборов (например, прокурорский надзор за соблюдением законов о выборах; деятельность правоохранительных органов по выявлению, предупреждению и пресечению административных правонарушений и преступных посягательств в избирательном процессе; общественный контроль избирательного процесса; развитие правосознания и повышение уровня правовой культуры организации и проведения выборов и др.). С учетом этого представляется, что система конституционно-правовых гарантий легитимации избирательного процесса имеет более сложный характер и должна включать в себя несколько элементов:

а) гарантии реализации основных избирательных прав и свобод граждан (свобода и добровольность участия в выборах; тайна голосования; сохранение избирательных прав за гражданами, проживающими за пределами Российской Федерации, на выборах в федеральные органы государственной власти; свобода 
деятельности общественных объединений; политическое многообразие и многопартийность; свобода собраний и др.);

б) нормативные гарантии (совершенство законодательства о выборах; недопустимость издания законов, отменяющих или умаляющих права и свободы человека и гражданина; вступление в силу изменений в законодательство о выборах после проведения очередных избирательных кампаний);

в) организационные гарантии (обязательность проведения выборов в установленные законом сроки; ограничение срока полномочий выборных органов государственной власти и органов местного самоуправления; недопустимость замены выборов референдумом; недопустимость проведения выборов одновременно с референдумом Российской Федерации; независимость избирательных комиссий от органов государственной власти и органов местного самоуправления);

г) информационные гарантии (свобода массовой информации; свобода слова; открытость и гласность в деятельности избирательных комиссий; право граждан Российской Федерации, общественных объединений на проведение агитации в законных формах и законными методами; право кандидатов и избирательных объединений на беспрепятственное распространение агитационных материалов; содействие государственных и муниципальных органов в организации и проведении агитационных публичных мероприятий; обеспечение государственными и муниципальными организациями СМИ равных условий проведения предвыборной агитации зарегистрированным кандидатам и избирательным объединениям, зарегистрировавшим списки кандидатов; обнародование отчетов о средствах на ведение избирательной кампании и их расходовании; опубликование избирательными комиссиями данных об итогах голосования и о результатах выборов; предоставление комиссиями данных об итогах голосования по каждому избирательному участку; размещение данных протоколов всех комиссий об итогах голосования и о результатах выборов в информационно-телекоммуникационной сети «Интернет»); 
д) контрольные гарантии (конституционный контроль избирательного процесса; общественный контроль избирательного процесса; возможность обращения в международные организации по защите прав и свобод человека в случае исчерпания всех имеющихся внутригосударственных средств правовой защиты; иностранное (международное) наблюдение на выборах, проводимых в Российской Федерации);

е) правоохранительные гарантии (судебная защита избирательных прав участников выборов; прокурорский надзор за соблюдением законов о выборах; деятельность избирательных комиссий по привлечению правонарушителей к конституционно-правовой ответственности; деятельность правоохранительных органов по выявлению, предупреждению и пресечению административных правонарушений и преступных посягательств в избирательном процессе);

ж) финансово-экономические гарантии (сочетание государственного финансирования с возможностью использования негосударственных средств; периодическое предоставление отчетов о средствах, поступающих на ведение избирательной кампании, и их расходовании);

3) идеологические гарантии (развитие правосознания и повышение уровня правовой культуры организации и проведения выборов).

Основой системы конституционно-правовых гарантий легитимации избирательного процесса являются гарантии реализации основных избирательных прав и свобод граждан. Данная группа гарантий определяет содержательную характеристику легитимации избирательного процесса. Все остальные конституционно-правовые гарантии (нормативные, организационные, информационные, контрольные, правоохранительные, финансово-экономические, идеологические) призваны обеспечивать реализацию гарантий основных избирательных прав и свобод граждан и выполняют по отношению к ним второстепенную роль.

Рассмотрим эту группу гарантий.

В пункте 3 статьи 3 Федерального закона от 12 июня 2002 г. № 67-Ф3 закреплено, что «участие гражданина Российской Федерации в выборах и 
референдуме является свободным и добровольным. Никто не вправе оказывать воздействие на гражданина с целью принудить его к участию или неучастию в выборах и референдуме либо воспрепятствовать его свободному волеизъявлению». Участие в выборах осуществляется на основе всеобщего, равного и прямого избирательного права при тайном голосовании.

В статье 7 комментируемого Федерального закона указано, что «голосование на выборах является тайным, исключающим возможность какоголибо контроля за волеизъявлением гражданина». Тайное голосование гарантирует защиту избирателей от воздействия, которое может быть оказано, если другие граждане (общественные объединения) узнают о том, как они проголосовали.

Граждане, проживающие за пределами территории Российской Федерации, сохраняют полноту избирательных прав на выборах в федеральные органы государственной власти. Дипломатические представительства, консульские учреждения Российской Федерации обязаны оказывать содействие гражданам Российской Федерации в реализации избирательных прав при проведении федеральных выборов.

В соответствии с частью 1 статьи 30 Конституции гарантируется свобода деятельности общественных объединений. Никто не может быть принужден к вступлению в какое-либо объединение или пребыванию в нем. Граждане имеют право создавать по своему выбору общественные объединения без предварительного разрешения органов государственной власти и органов местного самоуправления, а также право вступать в такие общественные объединения на условиях соблюдения норм их уставов. Согласно статье 15 Федерального закона «Об общественных объединениях» общественные объединения свободны в определении своей внутренней структуры, целей, форм и методов своей деятельности. Государство обеспечивает соблюдение прав и законных интересов общественных объединений, оказывает поддержку их деятельности.

В Российской Федерации признаются политическое многообразие и многопартийность. Государством гарантируется равенство политических партий 
перед законом независимо от изложенных в их учредительных и программных документах идеологии, целей и задач. Государством обеспечивается соблюдение прав и законных интересов политических партий.

Статья 31 Конституции предусматривает право граждан Российской Федерации собираться мирно, без оружия, проводить собрания, митинги и демонстрации, шествия и пикетирование. Данное конституционное положение находит развитие в Федеральном законе от 19 июня 2004 г. № 54-Ф3 «О собраниях, митингах, демонстрациях, шествиях и пикетированиях» ${ }^{1}$.

Учитывая, что перечисление в Конституции основных прав и свобод не должно толковаться как отрицание или умаление других общепризнанных прав и свобод человека и гражданина, перечень конституционно-правовых гарантий реализации прав и свобод носит открытый характер.

Основные избирательные права и свободы граждан содержатся в соответствующих нормативных правовых актах. Поэтому существенное значение для легитимации избирательного процесса приобретают условия и юридические средства, обеспечивающие выражение и закрепление демократических норм избирательного права.

К числу первоочередных нормативных гарантий относится совершенство законодательства о выборах. Признаками качества избирательных законов являются выполнение возложенной на законы роли социальных регуляторов, принятие с соблюдением установленных процедур в пределах предметов ведения, соответствие Конституции и другим законодательным актам, проработанность юридической техники. Качество принимаемых законодательных актов, регулирующих общественные отношения, возникающие в ходе выборов, непосредственно влияет на соблюдение избирательных прав граждан, конституционных свобод участников избирательного процесса, состояние защищенности демократических основ народовластия и незыблемость конституционного строя Российской Федерации.

\footnotetext{
${ }^{1}$ См. СЗ РФ. 2004. № 25. Ст. 2485.
} 
Часть 2 статьи 55 Конституции Российской Федерации определяет, что в Российской Федерации не должны издаваться законы, отменяющие или умаляющие права и свободы человека и гражданина. Данное конституционное положение в полной мере распространяется и на законодательство о выборах. Обеспечение этой гарантии следовало бы увязать с установлением уголовной или административной ответственности за принятие государственными органами и их должностными лицами нормативных правовых актов, противоречащих Конституции Российской Федерации, федеральным конституционным и федеральным законам, повлекших за собой массовые нарушения прав и свобод граждан, угрозу единству и территориальной целостности, обороноспособности и безопасности государства, единству правового и экономического пространства Российской Федерации.

Нормативной гарантией легитимации избирательного процесса является недопустимость обновления избирательного законодательства в интересах претендентов на выборные должности и депутатские мандаты в период избирательной кампании. В соответствии с пунктом 3 статьи 11 Федерального закона от 12 июня 2002 г. № 67-Ф3 в случае принятия в период избирательной кампании, в период кампании референдума субъекта Российской Федерации или местного референдума закона, содержащего положения, которыми определяется порядок подготовки и проведения соответствующих выборов, референдума, либо в случае внесения в этот период в закон изменений, касающихся порядка подготовки и проведения соответствующих выборов, референдума, указанные закон и изменения применяются к выборам, которые назначены после их вступления в силу, и к референдуму, инициатива проведения которого выдвинута после вступления в силу указанных закона и изменений.

Важнейшей организационной гарантией выступает обязательность проведения выборов в установленные законом сроки ${ }^{1}$. В соответствии со статьей 9 Федерального закона от 12 июня 2002 г. № 67-Ф3 выборы федеральных органов

${ }^{1}$ См.: Иванченко А.В., Прудникова Т.А. Конституционно-правовые гарантии от монополизации власти // Вестник Московского университета МВД России. 2004. № 2. С. 36-39. 
государственной власти, органов государственной власти субъектов Российской Федерации, органов местного самоуправления или депутатов указанных органов являются обязательными, периодическими и проводятся в сроки, обеспечивающие соблюдение сроков полномочий этих органов или депутатов.

В пункте 2 статьи 1 Федерального закона от 6 октября 1999 г. № 184-Ф3 отмечается, что органы государственной власти субъектов Российской Федерации обеспечивают реализацию прав граждан на участие в управлении делами государства как непосредственно, так и через своих представителей, в том числе путем законодательного закрепления гарантий своевременного назначения даты выборов в органы государственной власти субъекта Российской Федерации и органы местного самоуправления и гарантий периодического проведения указанных выборов.

Пункт 1 статьи 8 Федерального закона от 12 июня 2002 г. № 67-Ф3 ограничивает срок полномочий выборных органов государственной власти и органов местного самоуправления. Срок, на который избираются федеральные органы государственной власти, органы государственной власти субъектов Российской Федерации, органы местного самоуправления, депутаты указанных органов, а также срок полномочий указанных органов и депутатов устанавливаются соответственно Конституцией Российской Федерации, федеральными законами, конституциями (уставами), законами субъектов Российской Федерации, уставами муниципальных образований ${ }^{1}$.

Среди организационных гарантий легитимации избирательного процесса необходимо выделить недопустимость замены выборов референдумом и недопустимость проведения выборов одновременно с референдумом Российской Федераций․ Согласно части 5 статьи 6 Федерального конституционного закона «О референдуме Российской Федерации» на референдум не могут выноситься вопросы:

1 Аналогичные правовые положения в отношении срока полномочий депутатов законодательных (представительных) органов государственной власти субъекта Российской Федерации закреплены в пункте 5 статьи 4 Федерального закона от 6 октября 1999 г. № 184-ФЗ.

${ }^{2}$ См.: Иванченко А.В., Прудникова T.A. Указ соч. С. 37. 
- о досрочном прекращении или продлении срока полномочий Президента Российской Федерации, Государственной Думы Федерального Собрания Российской Федерации, а также о проведении досрочных выборов Президента Российской Федерации, депутатов Государственной Думы Федерального Собрания Российской Федерации либо о перенесении сроков проведения таких выборов;

- об избрании, о назначении на должность, досрочном прекращении, приостановлении или продлении полномочий лиц, замещающих государственные должности Российской Федерации;

- об избрании, о досрочном прекращении, приостановлении или продлении срока полномочий органов, образованных в соответствии с международным договором Российской Федерации либо должностных лиц, избираемых или назначаемых на должность в соответствии с международным договором Российской Федерации, а также о создании таких органов либо назначении на должность таких лиц, если иное не предусмотрено международным договором Российской Федерации.

В пункте 3 статьи 7 Федерального конституционного закона «О референдуме Российской Федерации» определено, что референдум не проводится в период избирательной кампании, проводимой одновременно на всей территории Российской Федерации.

Основополагающее значение для легитимации избирательного процесса имеет независимость избирательных комиссий от органов государственной власти и органов местного самоуправления ${ }^{1}$. В соответствии с пунктом 7 статьи 3 Федерального закона от 12 июня 2002 г. № 67-Ф3 вмешательство в деятельность избирательных комиссий со стороны законодательных (представительных) и исполнительных органов государственной власти, органов местного самоуправления, организаций, должностных лиц, иных граждан не допускается.

\footnotetext{
${ }^{1}$ См.: Полев В.А. К вопросу о независимости избирательных комиссий // Журнал о выборах. 2003. № 2. С. 53-54; Добровольский П.Е. О независимости избирательных комиссий муниципальных образований // Административное и муниципальное право. 2008. № 10. С. 10-20; Колюшин Е.И. Концепция модернизации избирательного и связанного с ним законодательства // Вестник Московского университета. 2010. № 1. С. 76.
} 
Для обеспечения подлинной самостоятельности избирательных комиссий приведенное положение необходимо дополнить нормами о материальном и социальном (медицинском, жилищно-бытовом, санаторно-курортном) обеспечении комиссий из федерального бюджета, а также о замещении руководящих должностей в избирательных комиссиях беспартийными гражданами или представителями от разных партий.

Легитимация выборов в демократическом государстве невозможна без наличия взаимосвязанной совокупности информационных гарантий ${ }^{1}$. Демократические выборные процедуры предполагают свободу массовой информации, а также информационную прозрачность избирательного процесса и деятельности участников и организаторов выборов.

На основании части 3 статьи 29 Конституции Российской Федерации никто не может быть принужден к выражению своих мнений и убеждений или отказу от них. Часть 5 статьи 29 Конституции гарантирует свободу массовой информации и запрещает цензуру в Российской Федерации.

Открытость и гласность в деятельности комиссий позволяет общественности контролировать избирательный процесс, обеспечивает законность осуществления избирательных процедур и повышает доверие населения к выборам. В пункте 5 статьи 3 Федерального закона от 12 июня 2002 г. № 67-Ф3 указано, что «деятельность комиссий при подготовке и проведении выборов, референдума, подсчете голосов, установлении итогов голосования, определении результатов выборов, референдума осуществляется открыто и гласно». На всех заседаниях комиссии, а также при подсчете голосов избирателей и осуществлении работы со списками избирателей, с бюллетенями, открепительными удостоверениями, протоколами об итогах голосования вправе присутствовать члены вышестоящих комиссий и работники их аппаратов, кандидат, зарегистрированный данной либо вышестоящей комиссией, или его доверенное лицо, уполномоченный представитель или доверенное лицо

\footnotetext{
${ }^{1}$ См.: Навальный С.В. Легитимация государственной власти в процессе информационного обеспечения избирательного процесса // Право и государство: теория и практика. 2010. № 4. С. 148-151.
} 
избирательного объединения, список кандидатов которого зарегистрирован данной либо вышестоящей комиссией, или кандидат из указанного списка. Комиссия обязана обеспечить оповещение и возможность свободного доступа указанных лиц на свои заседания и в помещения.

Пункт 1 статьи 48 Федерального закона от 12 июня 2002 г. № 67-Ф3 закрепляет положение, что граждане Российской Федерации, общественные объединения вправе в допускаемых законом формах и законными методами проводить предвыборную агитацию, агитацию по вопросам референдума.

Государственные органы, органы местного самоуправления обязаны оказывать содействие зарегистрированным кандидатам, избирательным объединениям в организации и проведении агитационных публичных мероприятий, а государственные и муниципальные СМИ обязаны обеспечить равные условия проведения предвыборной агитации зарегистрированным кандидатам и избирательным объединениям, зарегистрировавшим списки кандидатов, в том числе для представления избирателям предвыборных программ. В информационных теле- и радиопрограммах, публикациях в периодических печатных изданиях не должно отдаваться предпочтение какомулибо кандидату, избирательному объединению, в том числе по времени освещения их предвыборной деятельности, объему печатной площади, отведенной для таких сообщений.

К сожалению, данная информационная гарантия носит декларативный характер, поскольку действующее законодательство позволяет под видом информирования об общественно-политической деятельности кандидатов в депутаты или на выборные должности, дифференциации этой информации по времени и другим параметрам оказывать воздействие на волеизъявление избирателей ${ }^{1}$.

Органы местного самоуправления по предложению соответствующей комиссии обязаны выделить специальные места для размещения печатных

1 См.: Колюшин Е.И. Концепция модернизации избирательного и связанного с ним законодательства // Вестник Московского университета. 2010. № 1. С. 70. Следовало бы возложить на избирательные комиссии обязанность осуществлять контроль работы СМИ за соблюдением равенства участников выборов при освещении их деятельности и принимать меры по пресечению нарушений порядка информирования избирателей. 
агитационных материалов на территории каждого избирательного участка. Зарегистрированным кандидатам и избирательным объединениям должна быть выделена равная площадь для размещения печатных агитационных материалов (пункт 7 статьи 54 Федерального закона от 12 июня 2002 г. № 67-Ф3).

На основании пункта 8 статьи 59 Федерального закона от 12 июня 2002 г. № 67-Ф3 избирательные комиссии должны периодически направлять в СМИ для опубликования сведения о поступлении и расходовании средств избирательных фондов. В свою очередь, редакции государственных и муниципальных периодических печатных изданий обязаны публиковать указанные сведения в течение трех дней со дня получения. Копии итоговых финансовых отчетов кандидатов и избирательных объединений не позднее чем через пять дней со дня их получения передаются комиссиями в СМИ для опубликования.

В соответствии с пунктом 4 статьи 72 Федерального закона от 12 июня 2002 г. № 67-Ф3 комиссии всех уровней, за исключением участковых комиссий, публикуют (обнародуют) данные, которые содержатся в протоколах комиссий соответствующего уровня об итогах голосования и о результатах выборов, и данные, которые содержатся в протоколах об итогах голосования непосредственно нижестоящих комиссий и на основании которых определялись итоги голосования, результаты выборов в соответствующих комиссиях.

Комиссия предоставляет для ознакомления итоги голосования по каждому избирательному участку, территории, на которую распространяется деятельность комиссии, результаты выборов по избирательному округу в объеме данных, содержащихся в ее протоколе об итогах голосования и протоколах об итогах голосования непосредственно нижестоящих комиссий, избирателям, кандидатам, должностным лицам кандидатов, избирательных объединений, наблюдателям, иностранным (международным) наблюдателям, представителям СМИ по их требованию.

Официальное опубликование (обнародование) полных данных о результатах выборов в федеральные органы государственной власти Российской Федерации осуществляется в течение 3 месяцев со дня голосования. Официальное 
опубликование (обнародование) полных данных о результатах выборов в органы государственной власти субъекта Российской Федерации, органы местного самоуправления осуществляется в течение 2 месяцев со дня голосования. В течение 3 месяцев со дня официального опубликования (обнародования) полных данных о результатах выборов в органы государственной власти Российской Федерации данные, которые содержатся в протоколах всех комиссий об итогах голосования и о результатах выборов, размещаются в информационнотелекоммуникационной сети общего пользования «Интернет» ${ }^{1}$.

Ключевым элементом системы конституционно-правовых гарантий выступает конституционный контроль избирательного процесса, осуществляемый Президентом Российской Федерации, Конституционным Судом Российской Федерации, Федеральным Собранием Российской Федерации, Правительством Российской Федерации, Уполномоченным по правам человека в Российской Федерации, судами, прокуратурой, Министерством юстиции Российской Федерации. Конституционный контроль в сфере выборов предполагает два основных аспекта: проверку соответствия Конституции Российской Федерации законов и иных нормативных правовых актов о выборах; контроль за соблюдением Конституции Российской Федерации и законодательства о выборах государственными органами, должностными лицами, общественными объединениями, политическими партиями, средствами массовой информацииㄹ․

Высшим органом конституционного контроля в Российской Федерации является Конституционный Суд Российской Федерации ${ }^{3}$. Он осуществляет свои

${ }^{1}$ См. также Вешняков A.A. Общая характеристика гарантий обеспечения избирательных прав граждан с использованием ГАС «Выборы» // Конституционное и муниципальное право. 2006. № 8. С. 2-9.

${ }^{2}$ Конституционный контроль избирательного процесса подробно рассмотрен в работах Н.С. Бондаря, Ю.А. Веденеева, М.Б. Долматовой, С.Е. Заславского, В.Д. Зорькина, В.И. Лысенко. См.: Бондарь Н.С. Конституционное правосудие как средство решения избирательных споров / Избирательное законодательство и выборы в регионах: теория и практика. М., 2005. С. 43-58; Веденеев Ю.А., Лысенко В.И. Современное избирательное право и решения Конституционного Суда Российской Федерации: юридическая структура и динамика / Избирательное право и избирательный процесс в решениях Конституционного Суда Российской Федерации (1992-1999). М., 2000. С. 6068; Долматова М.Б. Правовые позиции Конституционного Суда Российской Федерации в решениях по вопросам избирательного права: Автореф. дис. ...канд. юрид. наук. Казань, 2005. 31 с; Заславский С.Е. Правовой статус политических партий в решениях Конституционного Суда Российской Федерации // Сравнительное конституционное обозрение. 2005. № 2. С. 152-157; Зорькин В.Д. Защита конституционных основ публичной власти и политических прав граждан в практике Конституционного Суда России / Конституционное правосудие в новом тысячелетии. Ереван, 2005. С. 55-67.

${ }^{3}$ Вопросы судебного конституционного контроля избирательного процесса рассматриваются в параграфе 
функции посредством особой процедуры конституционного судопроизводства. В осуществлении конституционного контроля избирательного процесса в пределах своей компетенции принимают участие и другие субъекты. Главенствующая роль среди них принадлежит Президенту Российской Федерации ${ }^{1}$.

Часть 2 статьи 80 Конституции определяет статус Президента Российской Федерации как гаранта Конституции Российской Федерации, прав и свобод человека и гражданина. В установленном Конституцией порядке он принимает меры по охране суверенитета Российской Федерации, ее независимости и государственной целостности, обеспечивает согласованное функционирование и взаимодействие органов государственной власти. Глава государства обладает правом отклонения федеральных законов, отмены актов Правительства Российской Федерации, приостановления актов органов исполнительной власти субъектов Российской Федерации, нарушающих положения Конституции.

Анализ полномочий других несудебных органов конституционного контроля показывает, что их участие в конституционном контроле избирательного процесса, как правило, охватывает: право обращения в Конституционный Суд Российской Федерации с запросом о соответствии Конституции Российской Федерации федеральных законов, нормативных правовых актов Президента Российской Федерации, Совета Федерации, Государственной Думы, Правительства Российской Федерации, конституций республик, уставов, а также законов и иных нормативных правовых актов субъектов Российской Федерации, регулирующих общественные отношения в сфере выборов; осуществление экспертизы законодательства о выборах на предмет ее соответствия Конституции и федеральным законам о выборах.

Конституционный контроль избирательного процесса неразрывно связан с общественным.

Развитие институтов гражданского общества, подлинная демократизация политической системы Российской Федерации невозможны без осуществления

1 См.: Осипян С. Президентская власть и защита Конституции Российской Федерации (проблемы конституционного контроля и конституционного надзора) // Право и жизнь. 1998. № 15. С. 50-69; Плеханова Л.Н. Президент Российской Федерации в системе органов правовой охраны Конституции Российской Федерации. Автореф. дис. ...канд. юрид. наук. Томск, 2004. 26 с. 
общественного наблюдения за выборами. Субъектами общественного контроля избирательного процесса выступают политические партии, СМИ, общественные палаты, общественные приемные, объединения избирателей ${ }^{1}$.

В системе контрольных гарантий легитимации избирательного процесса следует отдельно рассматривать предусмотренную статьей 46 Конституции Российской Федерации возможность обращения в международные организации по защите прав и свобод человека в случае исчерпания всех имеющихся внутригосударственных средств правовой защиты, а также иностранное (международное) наблюдение на выборах, проводимых в Российской Федерации ${ }^{2}$.

Особое место среди правоохранительных гарантий занимает судебная защита избирательных прав участников выборов, предусмотренная частью 1 статьи 46 Конституции Российской Федерации, статьей 75 Федерального закона от 12 июня 2002 г. № 67-ФЗ. Решения и действия (бездействие) органов государственной власти, органов местного самоуправления, общественных объединений и должностных лиц, а также решения и действия (бездействие) комиссий и их должностных лиц, нарушающие избирательные права граждан и право на участие в референдуме, могут быть обжалованы в суд. С жалобами на решения и действия (бездействие), нарушающие избирательные права граждан и право граждан на участие в референдуме, могут обращаться избиратели, участники референдума, кандидаты, их должностные лица, избирательные объединения и их должностные лица, иные общественные объединения, инициативная группа по проведению референдума и ее уполномоченные представители, наблюдатели, а также комиссии.

Важной правоохранительной гарантией выступает прокурорский надзор за соблюдением законов о выборах. Сфера правозащитной деятельности

${ }^{1}$ Подробней см. параграф 4.2 монографии. Проблемы общественного контроля избирательного процесса рассмотрены в работах А.П. Любимова, В.П. Волкова, О.В. Дамаскина, С.М. Шапиева. См.: Любимов А.П. Об общественном (публичном) контроле за компьютерным подсчетом голосов во время выборов // Законодательство. 1998. № 11. С. 69-76; Волков В.П., Дамаскин О.В., Шапиев С.М. Некоторые проблемы и пути их решения для обеспечения законности избирательного процесса в Российской Федерации. М., 2009. С. 46, 129-131.

${ }^{2}$ В ряде случаев участники российских выборов реализовали свое конституционное право обращения в международные правозащитные организации. См. Судебные решения Европейского Суда по правам человека «Антоненко против России» (23 мая 2006 г.), «Артемов против России» (7 декабря 2006 г.). «Российская консервативная партия предпринимателей и другие против России» (11 января 2007 г.), «Краснов и Скуратов против России» (31 марта 2008 г.). Развитию иностранного (международного) контроля избирательного процесса посвящен параграф 4.2. 
прокуратуры распространяется на федеральные министерства и ведомства, представительные (законодательные) и исполнительные органы субъектов Российской Федерации, органы местного самоуправления, органы военного управления, органы контроля, их должностных лиц, а также органы управления и руководителей коммерческих и некоммерческих организаций. Надзорные полномочия прокуратуры охватывают надзор за соответствием федеральным законам нормативных правовых актов, издаваемых ЦИК России и другими избирательными комиссиями, и надзор за законностью действий избирательных комиссий всех уровней, органов власти, политических партий и общественных объединений при реализации законов о выборах ${ }^{1}$.

Защите конституционного строя, основных прав и свобод граждан служит деятельность избирательных комиссий по привлечению правонарушителей к конституционно-правовой ответственности. Основанием наступления конституционно-правовой ответственности в избирательном процессе служит нарушение законодательства о выборах. Законодателем предусмотрены различные меры конституционно-правовой ответственности участников выборов за совершение избирательных правонарушений: предупреждение; отказ в регистрации кандидата (списка кандидатов); отмена регистрации кандидата (списка кандидатов); исключение группы кандидатов из списка кандидатов; признание итогов голосования, результатов выборов недействительными; отмена решения об итогах голосования, результатов выборов; отзыв аккредитации наблюдателя; расформирование избирательной комиссии и др. ${ }^{2}$ В целях устранения выявленных нарушений прав граждан избирательные комиссии вправе обратиться в суды и правоохранительные органы.

\footnotetext{
${ }^{1}$ Подробней см. параграф 2.3 монографии.

2 Меры конституционно-правовой ответственности за нарушения законодательства о выборах рассмотрены в главе 2 монографии. См. также Колосова H.M. Конституционная ответственность в Российской Федерации: Ответственность органов государственной власти и иных субъектов права за нарушение конституционного законодательства Российской Федерации. М.: Городец, 2000; Зайцева Е.В. Избирательное право. Тверь: Твер. гос. ун-т, 2001. С. 138-141; Игнатенко В.В., Ищенко Е.П. Юридическая ответственность за нарушения избирательного законодательства. М., 1999. 96 с; Игнатенко B.B. Конституционно-правовая ответственность в избирательном процессе // Академический юридический журнал. 2002. № 3. С. 18-29; Дмитриев Д.О. Отказ в регистрации и отмена регистрации - основные меры конституционно-правовой ответственности кандидатов // Юстиция. 2006. № 6. C. 51-59.
} 
Легитимация избирательного процесса опирается на деятельность правоохранительных органов по выявлению, предупреждению и пресечению преступных посягательств и административных правонарушений в процессе организации и проведения выборов ${ }^{1}$.

Самостоятельный блок конституционно-правовых гарантий легитимации избирательного процесса составляют финансово-экономические гарантии.

В соответствии с пунктом 1 статьи 57 Федерального закона от 12 июня 2002 г. № 67-Ф3 расходы, связанные с подготовкой и проведением выборов соответствующего уровня в Российской Федерации, эксплуатацией и развитием средств автоматизации и обучением организаторов выборов и избирателей, производятся избирательными комиссиями за счет средств, выделяемых на эти цели из соответствующего бюджета.

Государственное финансирование выборов сочетается с возможностью использования участниками избирательного процесса негосударственных средств. Согласно пункту 5 статьи 59 Федерального закона от 12 июня 2002 г. № 67-Ф3 граждане и юридические лица вправе оказывать финансовую поддержку кандидату, избирательному объединению через соответствующие избирательные фонды.

Важнейшей финансово-экономической гарантией легитимации избирательного процесса является периодическое предоставление отчетов о средствах, поступающих на ведение избирательной кампании, и их расходовании.

В современной правовой науке в качестве одной из основных гарантий, обеспечивающих легитимацию избирательного процесса, реализацию избирательных прав и оказывающих заметное влияние на непосредственное осуществление гражданами России принадлежащей им власти, выделяется

1 См.: Глушенко П.П., Гнетов А.В. Механизм использования избирательными комиссиями и правоохранительными органами правовых методов, средств и способов обеспечения реализации и защиты избирательных прав граждан / Проблемы дальнейшего совершенствования механизма управления правозащитной деятельностью. Материалы Междунар. науч.-практ. конф. СПб, 2007. С. 89-110; Климова Ю.Н. Взаимодействие избирательной комиссии с правоохранительными органами при обеспечении законности и правопорядка на территории избирательного округа // Вестник ЦИК России. 2006. № 11; Долгий О.В., Проценко С.В. Некоторые вопросы практики борьбы с правонарушениями в сфере организации и проведения выборов и референдумов // Юридический мир. 2008. № 8. С. 24-27. 
развитие правосознания и повышение уровня правовой культуры организации и проведения выборов ${ }^{1}$.

Практика проходящих в Российской Федерации избирательных кампаний свидетельствует, с одной стороны, о развитии демократических институтов и совершенствовании законодательства о выборах, a с другой стороны, о недостаточной правовой культуре избирателей, организаторов выборов и иных участников избирательного процесса, связанной, в частности, с их низкой политической активностью, индифферентностью к настойчивым попыткам проникновения представителей организованных преступных групп в органы государственной власти и местного самоуправления, ростом преступных посягательств на избирательные права. В современных условиях низкий уровень жизни значительной части населения России ведет к концентрации усилий людей на своем материальном обеспечении и снижению интереса к общественным и государственным делам. Как справедливо отметил О.В. Дамаскин, «неразвитость правосознания значительной части граждан дает возможность использования выборов для «декоративного» придания легитимного характера формированию органов власти и манипулирования волей избирателей»².

Правовая культура организации и проведения выборов с позиций защиты конституционного строя может рассматриваться двояко: во-первых, как состояние правосознания, материализованные юридические ценности и юридически значимое поведение людей, связанное с восприятием участниками избирательного процесса угроз конституционному строю, возникающих в ходе выборов; во-вторых, как предпосылка эффективной деятельности по защите конституционного строя в избирательном процессе.

В структуре правовой культуры организации и проведения выборов можно условно выделить четыре основных элемента: правовую культуру организаторов

1 См.: Борноволоков П.А. Взаимосвязь выборов и правовой культуры // Актуальные проблемы юриспруденции. Вып. 2. Тюмень, 2003. С. 12-13; Зиновьев А.В., Поляшова И.С. Выборы и правовая культура // Вестник Санкт-Петербургского университета МВД России. 2001. № 2. С. 21-32; Кейзеров Н.М., Смолина И.Г. Правовая культура избирательной кампании: в помощь избирателям и организаторам выборов. Абакан, 1995.108 c.

${ }^{2}$ См.: Дамаскин О.В. Легитимация результатов избирательного процесса в Российской Федерации // Журнал о выборах. 2008. № 3. С. 16. 
выборов; правовую культуру избирателей (граждан России и в предусмотренных законодательством случаях иностранных граждан); правовую культуру представителей средств массовой информации, избирательных объединений, кандидатов, их доверенных лиц, наблюдателей; правовую культуру иных участников избирательного процесса (государственных и муниципальных служащих, сотрудников правоохранительных органов, оказывающих содействие избирательным комиссиям). В основе предложенной классификации лежит целеполагание и роль той или иной категории участников избирательного процесса в выборной кампании.

Снижения потенциала угроз конституционному строю, возникающих в избирательном процессе, можно добиться путем стимулирования развития правовой культуры и целенаправленного воздействия на ее соответствующие структурные элементы. Исходя из изложенного, представляется возможным рассмотреть ряд направлений развития правовой культуры организации и проведения выборов в Российской Федерации.

Первое. Повышение профессиональной правовой культуры организаторов выборов должно быть направлено на формирование требовательного отношения к неукоснительному соблюдению установленной законом процедуры избирательных действий, создание непримиримого отношения указанной категории участников выборов к возможным правонарушениям в процессе организации и проведения выборов, обеспечение взаимной ответственности государства и личности в избирательном процессе.

Второе. Развитие правовой культуры избирателей должно преследовать цели повышения политической активности граждан в избирательном процессе, широкого использования предоставленных им прав и свобод в политической сфере, формирования осознанной необходимости и готовности оказывать содействие правоохранительным органам в выявлении, предупреждении и пресечении правонарушений (в том числе, в рассматриваемой области)ㄹ.

1 См.: Журавлев В.П. Проблемы повышения правовой культуры избирателей и совершенствования избирательного процесса / Образ государства в современном правосознании. Восьмые спиридоновские чтения. СПб, 2008. С. 144-151. 
Третье. Правовую культуру представителей СМИ, избирательных объединений, кандидатов, их доверенных лиц, наблюдателей представляется необходимым повышать в процессе изучения законодательства о выборах и подготовки к практическому овладению навыков его применения, обучения квалифицированному ведению избирательных кампаний на основе организации правовых консультаций и соответствующих курсов при избирательных комиссиях. Следовало бы усилить ответственность организаций теле- и радиовещания и периодических печатных изданий за использование технологий манипулятивного воздействия на общественное сознание ${ }^{1}$. Напротив, распространение в СМИ объективных материалов о деятельности избирательных комиссий, других участников избирательного процесса образует важнейший элемент доверия граждан к собственному государству.

Четвертое. Правовую культуру иных участников избирательного процесса (государственных и муниципальных служащих, сотрудников правоохранительных органов, оказывающих содействие избирательным комиссиям) целесообразно развивать в направлении непредвзятого и беспристрастного содействия работе избирательных комиссий, недопустимости непосредственного вовлечения в избирательный процесс, ущемления гарантированных конституцией прав и свобод граждан, законности прохождения избирательных кампаний².

Рассмотренная система конституционно-правовых гарантий легитимации избирательного процесса призвана обеспечить признание населением результатов выборов и доверие избирателей к сформированной представительной власти.

В настоящее время большинство населения Российской Федерации признает авторитет сформированной в условиях избирательных кампаний политической власти, и готово добровольно выполнять ее требования. Исследования Фонда «Общественное мнение» (ФОМ) показывают, что уровень

\footnotetext{
1 См.: Климова Ю.Н. Преступность и массовая коммуникация в период предвыборной агитации. Дис. ...канд. юрид. наук. Н.Новгород, 2003. 233 с; Климова Ю.Н. Проблемы противодействия правонарушениям в практике предвыборной агитации // Следователь. 2004. № 3. С. 50-52.

${ }^{2}$ См.: Зиновьев А.В., Поляшова И.С. Выборы и правовая культура // Вестник Санкт-Петербургского ун-та МВД России. 2001. № 2. С. 21-32; Коржиков О.Н. Пути повышения правовой культуры сотрудников правоохранительных органов // Правовая политика и правовая жизнь. 2007. № 4. С. 214-215.
} 
поддержки политической партии «Единая Россия» составляет от 53 до 60\%. По данным общероссийской выборки, от 8 до 10\% опрошенных высказались в поддержку КПРФ, ЛДПР получила от 6 до 7 \%, партия «Справедливая Россия» от 5 до 4\% ${ }^{1}$. Влияние «Единой России» на положение дел в стране оценивается избирателями как «очень высокое». 67\% опрошенных ответили, что партия оказывает влияние, при этом 58\% отметили что это «влияние позитивное», и только 9\% - что «влияние негативное». В феврале 2007 г. число респондентов, оценивающих влияние «Единой России» на ситуацию в стране как «позитивное», было 43\%, а в апреле 2008 г. оно составило 59\%. Рост позитивных оценок на 16\% за полтора года показывает доверие, которое население оказывает партии².

Опрос Левада - Центра об отношении граждан Российской Федерации к партии «Единая Россия» показал, что 59\% респондентов относятся к этой партии «очень положительно», 23\% не определились в своем отношении к ней, 12\% заявили об «отрицательном отношении» к партии. 1\% опрошенных признал, что «вообще не знают о существовании такой партии». Таким образом, большая часть населения Российской Федерации относится к сформированной представительной власти и правящей политической партии положительно 3 .

По данным проводимого в 2008 г. исследования ВЦИОМ, на вопрос «Как вы думаете, насколько честно обычно проходят избирательные кампании по выборам Президента Российской Федерации?» ответили: «безусловно честно»$15 \%$, «скорее честно» - 49\%, «скорее нечестно» - 15\%, «безусловно нечестно»$4 \%$, «затрудняюсь ответить» - 17\% опрошенных ${ }^{4}$. Социологические опросы показывают, что более $60 \%$ избирателей после выборов довольны их результатами. Если в 1999 г. считали выборы сфальсифицированными около 40\%, в 2003 г. - 18\%, то в 2007 г. - только $11 \%{ }^{5}$.

1 См. Опрос Фонда «Общественное мнение» 24-25 октября 2009 г. Опрошено 2000 респондентов в 100 населенных пунктах 44 субъектов Российской Федерации / Победители и проигравшие. Местные выборы 11 октября. М.: Изд-во Европа, 2010. С. 23-25.

2 См. Опрос Фонда «Общественное мнение» 26-27 сентября 2009 г. Опрошено 2000 респондентов в 100 населенных пунктах 44 субъектов Российской Федерации / Победители и проигравшие. Местные выборы 11 октября. М.: Изд-во Европа, 2010. С. 26-27.

3 См. Опрос Левада-Центра 16 - 19 октября 2009 г. Опрошено 1600 респондентов. Статистическая погрешность не превышает 3,4%/ Победители и проигравшие. Местные выборы 11 октября. М.: Изд-во Европа, 2010. C. 30-32.

${ }^{4}$ См. Итоги. 4 марта 2008.

${ }^{5}$ См.: Волков В.П., Дамаскин О.В., Шапиев С.М. Некоторые проблемы и пути их решения для обеспечения законности избирательного процесса в Российской Федерации. М.: РЦОИТ, 2009. С. 130. 
Аналогичная тенденция характерна и для региональных выборов. Так, по данным опросов ВЦИОМ, проведенных 23-25 октября 2009 г. в Москве, 41\% москвичей, принявших участие в выборах в Московскую городскую думу 11 октября 2009 г., доверяют итогам голосования и расценивают заявления оппозиционных партий о фальсификации результатов выборов как обычное поведение проигравших и попытку оправдаться перед избирателями и спонсорами за поражение. Около 26 \% опрошенных придерживаются мнения, что нарушения на выборах действительно были, но не настолько серьезные, как считает оппозиция. $51 \%$ респондентов считают, что пересматривать результаты выборов не следует ${ }^{1}$.

Таким образом, анализ общественных настроений свидетельствует о законном характере формирования публичной власти и легитимности избранных органов народного представительства в Российской Федерации.

Проведение свободных и честных выборов укрепляет взаимосвязь между избирателями и выборными институтами власти, снижает уровень социальной напряженности в обществе. Легитимация избирательного процесса в интересах защиты конституционного строя способствует соблюдению конституционных прав и свобод участников выборов, стабильности российской системы народовластия и укреплению государственности.

\section{Выводы:}

1. В законодательстве, регулирующем организацию и проведение выборов в Российской Федерации, на сегодняшний день не полностью ликвидированы пробелы и коллизии, часть из которых носит коррупциогенный характер. Недостатки законодательства о выборах продолжают оказывать негативное воздействие на избирательный процесс и защиту конституционного строя России.

На федеральном уровне не регулируются отношения, связанные с политической рекламой вне периода избирательной кампании; не решены правовые вопросы противодействия использованию сети «Интернет» для

\footnotetext{
${ }^{1}$ В ходе социологического исследования ВЦИОМ было опрошено 1000 жителей г. Москвы в возрасте 18 лет и старше в 17 избирательных округах г. Москвы. Статистическая погрешность не превысила 3,2\%.
} 
осуществления экстремистской деятельности в условиях выборов; не предусмотрена юридическая ответственность иностранных (международных) наблюдателей за нарушение общепризнанных международных принципов и норм наблюдения за выборами. Анализ законодательства субъектов Российской Федерации о выборах показывает, что в некоторых из них сохраняются противоречия и несоответствие правовых положений нормам федеральных законов. Региональное законодательство о выборах не в полной мере отражает ограничения на агитационную деятельность экстремистского характера, в ряде субъектов Российской Федерации не регулируется порядок использования ГАС «Выборы», отсутствуют правовые положения о контрольно-ревизионных службах при избирательных комиссиях. В связи с этим требуется дальнейшее совершенствование правового обеспечения избирательного процесса в интересах защиты конституционного строя. Эта работа должна проходить путем совершенствования законодательной и подзаконной правовой основы.

Совершенствование законодательной основы необходимо осуществлять по следующим направлениям: совершенствование законодательной основы организации и проведения выборов в целях обеспечения соответствия международных обязательств России интересам защиты ее конституционного строя; приведение в соответствие интересам защиты конституционного строя и повышение качества федеральных законов; приведение в соответствие федеральному законодательству и повышение качества законодательства субъектов Российской Федерации о выборах. Совершенствование подзаконной правовой основы следует рассматривать с позиций федерального нормативного правового регулирования и нормативного правового регулирования на уровне субъектов Российской Федерации.

2. Анализ актуальных проблем развития международного и общественного контроля избирательного процесса свидетельствует о том, что в современной России востребованы новые подходы к объективному иностранному (международному) и национальному наблюдению за выборами, основанные на отказе от предвзятого и прогнозируемого характера деятельности миссий наблюдения, реальной защите прав человека, неукоснительном соблюдении 
норм избирательного права и совершенствовании эффективного общественного контроля организации и проведения выборов. В этих целях осуществляется постоянное повышение правовой культуры организаторов выборов, наблюдателей и представителей СМИ, обучение кандидатов, их доверенных лиц, уполномоченных представителей политических партий квалифицированному ведению избирательных кампаний. Существенный вклад в совершенствование контроля избирательного процесса вносит деятельность институтов гражданского общества (независимых СМИ, общественных организаций и объединений избирателей).

3. В рамках обеспечения легитимации избирательного процесса существенное значение имеют соответствующие конституционно-правовые гарантии. Конституционно-правовые гарантии легитимации избирательного процесса представляют собой совокупность условий и средств, обеспечивающих законность прохождения выборов, а также принятие обществом сформированной в условиях избирательной кампании политической власти. Закрепленные в Конституции Российской Федерации, федеральных конституционных и федеральных законах конституционно-правовые гарантии образуют систему, включающую в себя нормативные, организационные, информационные, контрольные, правоохранительные, финансово-экономические и идеологические гарантии легитимации избирательного процесса в интересах защиты конституционного строя. Данная система конституционно-правовых гарантий легитимации избирательного процесса призвана обеспечить признание населением результатов выборов и доверие избирателей к сформированной представительной власти. 


\section{ЗАКЛЮЧЕНИЕ}

Предпринятая попытка теоретического осмысления правового обеспечения защиты конституционного строя России в избирательном процессе позволила сделать выводы о содержании и юридическом оформлении деятельности государства по защите конституционного строя в условиях выборов, дала возможность исследовать состояние нормативного правового регулирования выборов в интересах защиты конституционного строя, сравнить преимущества и недостатки зарубежного и национального опыта нормативного правового обеспечения защиты конституционного строя в избирательном процессе.

Результатом исследования проблемы правового обеспечения защиты конституционного строя России в избирательном процессе явились следующие теоретические положения:

1. Выборы как одна из основ конституционного строя являются объектом защиты конституционного строя России в сфере организации и функционирования государственной власти. Проведение выборов служит гарантом своевременного воспроизводства и легитимации институтов представительной власти, выражает степень реализации конституционных прав и свобод граждан, обусловливает определенное состояние защищенности конституционного строя.

2. Защита конституционного строя России рассматривается в двух аспектах: 1) как направление обеспечения национальной безопасности, включающее в себя защиту основных прав и свобод человека и гражданина, обеспечение народовластия, верховенства и прямого действия Конституции Российской Федерации на всей территории государства, территориальной целостности и суверенитета, поощрение политического и идеологического плюрализма, развитие конституционного контроля за государственными и муниципальными органами, а также привлечение к юридической ответственности за нарушение конституционных норм (демократический подход к пониманию защиты 
конституционного строя); 2) как деятельность по сохранению с помощью аппарата управления и принуждения экономического, политического и идеологического господства правящей социальной группы (класса) через защиту основ их государства и права (антидемократический подход).

3. Защита конституционного строя России в избирательном процессе является элементом национальных интересов России. Систематизация интересов защиты конституционного строя России в избирательном процессе включает: сохранение политической стабильности в обществе; противодействие коррупции, сепаратизму, экстремизму и терроризму в условиях выборов; противодействие криминализации органов государственной власти и органов местного самоуправления; обеспечение легитимности формирования органов государственной власти и органов местного самоуправления; недопущение массовых нарушений избирательных прав граждан и иных участников избирательного процесса; обеспечение политической независимости государства в условиях агрессивного иностранного (международного) наблюдения за выборами; недопущение использования избирательных кампаний в качестве механизмов захвата политической власти ставленниками иностранных государств и финансируемых ими организаций.

4. Конституционно-правовой механизм защиты конституционного строя в избирательном процессе определяется как часть конституционного механизма защиты конституционного строя, при помощи которой осуществляется эффективное воздействие на общественные отношения, возникающие в связи с формированием органов публичной власти путем выборов, обеспечивается реализация конституционных прав участников избирательного процесса, защита демократических принципов и норм избирательного права, легитимация избирательного процесса.

Конституционно-правовой механизм защиты конституционного строя России в избирательном процессе включает в себя несколько подсистем: нормативную (нормативно-правовая основа защиты конституционного строя в избирательном процессе); институциональную (субъекты защиты 
конституционного строя в избирательном процессе); функциональнокоммуникативную (отношения между субъектами защиты конституционного строя).

5. Дано определение правового обеспечения защиты конституционного строя России в избирательном процессе, которое представляет собой деятельность государства в лице компетентных государственных органов по созданию, изменению, отмене и реализации правовых норм, способствующих организации и функционированию конституционно-правового механизма защиты конституционного строя России в избирательном процессе.

6. В работе обоснованы классификации субъектов защиты конституционного строя России по объему компетенции (субъекты общей компетенции и субъекты специальной компетенции) и особенностям правосубъектности (субъекты, непосредственно осуществляющие защиту конституционного строя в избирательном процессе, и субъекты, содействующие защите конституционного строя в избирательном процессе).

7. Исследование законодательных актов зарубежных стран в сфере защиты конституционного строя позволило выявить специфику правовой регламентации деятельности компетентных государственных органов и учреждений зарубежных стран по защите конституционного строя в избирательном процессе. Она заключается в прямом или косвенном санкционировании оперативно-розыскных и контрразведывательных мероприятий, направленных на оперативное изучение «нелояльных» партий и политических организаций, проверку «благонадежности» отдельных активистов и партийных функционеров, ограничении прав и свобод «неблагонадежных» граждан, претендующих на депутатский мандат или выборную должность.

8. В рамках изучения легитимации избирательного процесса сделан вывод о значимости соответствующих конституционно-правовых гарантий. Конституционно-правовые гарантии легитимации избирательного процесса представлены как совокупность условий и средств, обеспечивающих законность прохождения выборов, а также принятие обществом сформированной в условиях 
избирательной кампании политической власти. Закрепленные в Конституции Российской Федерации, федеральных конституционных и федеральных законах конституционно-правовые гарантии охарактеризованы как система, включающая в себя нормативные, организационные, информационные, контрольные, правоохранительные, финансово-экономические и идеологические гарантии легитимации избирательного процесса в интересах защиты конституционного строя России. Данная система конституционно-правовых гарантий легитимации избирательного процесса призвана обеспечить признание населением результатов выборов и доверие избирателей к сформированной представительной власти.

9. В работе сформулирован ряд законодательных предложений по правовому обеспечению защиты конституционного строя России в избирательном процессе:

- обоснована необходимость закрепления гарантий избирательных прав граждан, не являющихся членами политических партий;

- предложено введение юридической ответственности за получение избирателями выгоды материального и (или) нематериального характера за осуществление волеизъявления;

- оптимизирована процедура предупреждения и пресечения противоправной деятельности СМИ в условиях выборов;

- сформулировано предложение о недопустимости выдвижения и регистрации при проведении повторных выборов депутатов Государственной Думы Федерального Собрания Российской Федерации федеральных списков кандидатов политическими партиями, действия (бездействие) руководителей и уполномоченных представителей которых послужили основанием для признания судом выборов недействительными;

- аргументирована необходимость ограничения практики отказа лидеров партийных списков от получения депутатских мандатов путем отмены избирательной комиссией решения о признании кандидата избранным и передачи вакантного мандата следующему в порядке убывания числа поданных голосов избирателей списку кандидатов; 
- обосновано установление запрета на проведение публичных мероприятий с момента окончания агитационного периода до официального опубликования результатов выборов в целях противодействия экстремистской деятельности и массовым антиконституционным акциям;

- предложена норма об обязательном указании кандидатами в депутаты и (или) на выборные должности всех имеющихся судимостей (в т.ч. снятых и погашенных);

- обоснована необходимость увеличения до двух лет продолжительности запрета на внесение пожертвований некоммерческими организациями, получавшими материальную поддержку от иностранных государств, иностранных организаций, иностранных граждан, лиц без гражданства и международных организаций, для финансирования избирательных кампаний.

В качестве перспектив дальнейшей научной разработки затронутой проблемы правового обеспечения защиты конституционного строя России в избирательном процессе можно рассматривать:

- анализ и юридическое закрепление угроз конституционному строю, возникающих в избирательном процессе;

- исследование механизма легитимации результатов выборов с позиций правовой защиты конституционного строя;

- изучение отечественной и зарубежных избирательных систем в интересах защиты избирательных прав граждан и укрепления российской государственности;

- выявление и устранение коррупциогенных норм законодательства о выборах в Российской Федерации;

- совершенствование законодательства о политических партиях и средствах массовой информации в интересах защиты конституционного строя России. 


\section{СПИСОК ИСПОЛЬЗОВАННЫХ ИСТОЧНИКОВ И ЛИТЕРАТУРЫ}

1. Конституция Российской Федерации (с учетом поправок, внесенных законами Россииской Федерации о поправках К Конституции Российской Федерации от 30 декабря 2008 г. № 6-ФКЗ и от 30 декабря 2008 г. № 7-ФК3) // Рос. газ. 1993. 25 декабря; 2009. 21 января.

\section{Постановления и Определения Конституционного Суда Российской Федераџии}

2. Постановление Конституционного Суда Российской Федерации от 27 апреля 1998 г. N 12-П «О проверке конституционности отдельных положений Конституции Республики Башкортостан, Закона Республики Башкортостан «О Президенте Республики Башкортостан» (в ред. от 28 августа 1997 года) и Закона Республики Башкортостан «О выборах Президента Республики Башкортостан» // Рос. газ. 1998. 6 мая.

3. Постановление Конституционного Суда Российской Федерации от 17 ноября 1998 г. по делу о проверке конституционности отдельных положений Федерального закона от 21 июня 1995 г. «О выборах депутатов Государственной Думы Федерального Собрания Российской Федерации» // СЗ РФ. 1998. № 48. Ст. 5969.

4. Постановление Конституционного Суда Российской Федерации от 23 марта 2000 г. N 4-П «О признании не соответствующими Конституции Российской Федерации ч.2 ст.3 Закона Оренбургской области от 18 сентября 1997 года «О выборах депутатов Законодательного Собрания Оренбургской области» и Закона Оренбургской области от 18 сентября 1997 года «Об утверждении схемы избирательных округов для проведения выборов депутатов Законодательного Собрания Оренбургской области» // СЗ РФ. 2000. № 13. Ст. 1429.

5. Постановление Конституционного Суда Российской Федерации от 15 января 2002 г. N 1-П «О признании не соответствующими Конституции Российской Федерации положений, содержащихся в п.3 ст.64 Федерального закона «Об основных гарантиях избирательных прав и права на участие в референдуме граждан Российской Федерации» и п.3 ст.92 Федерального закона «О выборах депутатов Государственной Думы Федерального Собрания Российской Федерации» // С3 РФ. 2002. № 6. Ст. 626.

6. Постановление Конституционного Суда Российской Федерации от 22 января 2002 года № 2-П «По делу о проверке конституционности ч. 2 ст. 69 , ч. 2 ст. 70 и ст. 90 Конституции Республики Татарстан, а также п.2 ст. 4 и п.8 ст.21 Закона Республики Татарстан «О выборах депутатов Республики Татарстан» в связи с жалобой гражданина М.М.Салямова // Рос. газ. 2002. 31 января.

7. Постановление Конституционного Суда Российской Федерации от 12 апреля 2002 года № 9-П «По делу о проверке конституционности положений статей 13 и 14 Федерального закона «Об общих принципах организации законодательных (представительных) и исполнительных органов государственной власти субъектов Российской Федерации» в связи с жалобой гражданина А.П. Быкова, а также запросами Верховного Суда Российской Федерации и Законодательного Собрания Красноярского края» // Рос. газ. 2002. 25 апреля.

8. Постановление Конституционного Суда Российской Федерации от 11 июня 2002 г. № 10-П «О проверке конституционности положений п.1 ст.64, П.11 ст.32, пп. 8 и 9 ст.35, пп. 2 и 3 ст. 59 Федерального закона «Об основных гарантиях избирательных прав и права на участие в референдуме граждан Российской Федерации» // Рос. газ. 2002. 18 июня. 
9. Постановление Конституционного Суда Российской Федерации от 30 октября 2003 г. № 15-П «По делу о проверке конституционности отдельных положений Федерального закона «Об основных гарантиях избирательных прав и права на участие в референдуме граждан Российской Федерации» в связи с запросом группы депутатов Государственной Думы и жалобами граждан С.А. Баунтмана, К.А. Катаняна и К.С. Рожкова // Рос. газ. 2003. 31 октября.

10. Постановление Конституционного Суда Российской Федерации от 22 июня 2010 г. № 14-П «По делу о проверке конституционности подпункта «а» пункта 1 и подпункта «а» пункта 8 статьи 29 Федерального закона «Об основных гарантиях избирательных прав и права на участие в референдуме граждан Российской Федерации» в связи с жалобой гражданина А.М. Малицкого».

11. Определение Конституционного Суда Российской Федерации от 12 мая 2003 г. № 168-О «Об отказе в принятии к рассмотрению жалобы гражданина Быкова А.П. на нарушение его конституционных прав положениями подпункта «в» пункта 3 статьи 35 Устава Красноярского края и подпункта «в» пункта 1 статьи 4 Закона Красноярского края «О статусе депутата Законодательного собрания Красноярского края» / Избирательное право и избирательный процесс в решениях Конституционного Суда Российской Федерации. 2000-2007. Т. 1. М.: ЦИК России, 2008. С. 380-383.

12. Определение Конституционного Суда Российской Федерации от 6 июня 2003 г. № 185-О «Об отказе в принятии к рассмотрению жалобы гражданина Климентьева А.А. на нарушение его конституционных прав положениями пункта 10 статьи 32 и пункта 1 статьи 64 Федерального закона от 19 сентября 1997 г. «Об основных гарантиях избирательных прав и права на участие в референдуме граждан Российской Федерации», пункта 2 статьи 67 Закона Нижегородской области от 4 июня 2002 г. «О выборах глав местного самоуправления в Нижегородской области» и статьи 211 Гражданского процессуального кодекса РСФСР» / Избирательное право и избирательный процесс в решениях Конституционного Суда Российской Федерации. 2000-2007. Т. 1. М.: ЦИК России, 2008. C. 394-398.

13. Определение Конституционного Суда Российской Федерации от 4 декабря 2007 г. № 797-О-О «Об отказе в принятии к рассмотрению жалобы гражданина Кара-Мурзы В.В. на нарушение его конституционных прав положением пункта 3.1 статьи 4 Федерального закона «Об основных гарантиях избирательных прав и права на участие в референдуме граждан Российской Федерации» // Рос. газ. 2007. 26 декабря.

14. Определение Конституционного Суда Российской Федерации от 18 декабря 2007 г. № 920-О-О «Об отказе в принятии к рассмотрению жалобы гражданина Миронова В.В. на нарушение его конституционных прав положениями Федеральных законов «О выборах депутатов Государственной Думы Федерального Собрания Российской Федерации» и «О внесении изменений в отдельные законодательные акты Российской Федерации в части отмены формы голосования против всех кандидатов (против всех списков кандидатов)» / Избирательное право и избирательный процесс в решениях Конституционного Суда Российской Федерации. 2000-2007. Т. 2. М.: ЦИК России, 2008. С. 470-473.

15. Определение Конституционного Суда Российской Федерации от 1 октября 2009 г. № 1053-О-О «Об отказе в принятии к рассмотрению жалобы гражданина Байкова А.А. на нарушение его конституционных прав статьей 395 Уголовно-процессуального кодекса Российской Федерации, статьей 18 Федерального закона «О содержании под стражей подозреваемых и обвиняемых в совершении преступлений», статьей 4 Федерального закона «Об основных гарантиях избирательных прав и права на участие в референдуме граждан Российской Федерации», статьей 5 Федерального закона «О выборах депутатов Государственной Думы Федерального Собрания Российской Федерации» и пунктом 4 статьи 3 Федерального закона «О выборах Президента Российской Федерации». 


\section{Международные акты}

16. Всеобщая декларация прав человека, утвержденная Генеральной Ассамблеей ОOН 10 декабря 1948 г. Международное публичное право: Сб. документов. М., 1996. Т.1. С. 460-464.

17. Протокол № 1 к Европейской Конвенции о защите прав человека и основных свобод (Париж, 20 марта 1952 г.) // Международные избирательные стандарты. Сб. документов // Отв. ред.: кандидат юрид. наук А.А. Вешняков; науч. ред.: доктор юрид. наук В.И. Лысенко. М.: Издательство Весь Мир, 2004. С. 549-551.

18. Международный пакт от 16 декабря 1966 г. о гражданских и политических правах // Бюллетень Верховного Суда Российской Федерации. 1994 . № 12.

19. Документ Копенгагенского Совещания Конференции по человеческому измерению СБСЕ (Копенгаген, 29 июня 1990 г.) // Стандарты Совета Европы В области прав человека применительно к положениям Конституции Российской Федерации. М.: Институт права и публичной политики, 2002. 606 с.

20. Документ Московского Совешания Конференции по человеческому измерению СБСЕ (Москва, 3 октября 1991 г.) // Сов. журнал международного права. 1991. № 3-4. С. 115-133.

21. Декларация о критериях свободных и справедливых выборов (Париж, 26 марта 1994 г.) (По документам Межпарламентского Союза) М.: Известия, 1994. 11 с.

22. Декларация принципов международного наблюдения за выборами $(\mathrm{OOH}, 27$ октября 2005 г.) // Вестник ЦИК РФ. 2005. № 12. С. 5-18.

23. Резолюция 1264 (2001) Парламентской Ассамблеи Совета Европы «О кодексе надлежащей практики в избирательных вопросах» (Страсбург, 8 ноября 2001 г.) // Международные избирательные стандарты. Сб. документов // Отв. ред.: кандидат юрид. наук А.А. Вешняков; науч. ред.: доктор юрид. наук В.И. Лысенко. М.: Издательство Весь Мир, 2004. С. 593-594.

24. Резолюция 1308 (2002) Парламентской Ассамблеи Совета Европы «Об ограничениях на деятельность политических партий в государствах - членах Совета Европы» (Страсбург, 18 ноября 2002 г.) // Международные избирательные стандарты. Сб. документов // Отв. ред.: доктор юрид. наук В.И. Лысенко. М.: ЦИК России, 2009. C. 317-318.

25. Резолюция 1344 (2003) Парламентской Ассамблеи Совета Европы «Об угрозе для демократии со стороны экстремистских партий и движений в Европе» [Текст не опубликован.].

26. Резолюция 1546 (2007) Парламентской Ассамблеи Совета Европы «Кодекс поведения политических партий» // Международные избирательные стандарты. Сб. документов / Отв. ред.: доктор юрид. наук В.И. Лысенко. М.: ЦИК России, 2009. С. 344-348.

27. Резолюция 58/189 сессии Генеральной Ассамблеи ООН «Уважение принципов национального суверенитета и многообразия демократических систем в ходе выборов как важный элемент поощрения и защиты прав человека» (22 декабря 2003 г.) // Международные избирательные стандарты. Сб. документов // Отв. ред.: кандидат юрид. наук А.А. Вешняков; науч. ред.: доктор юрид. наук В.И. Лысенко. М.: Издательство Весь Мир, 2004. С. 167-168.

28. Рекомендация R (99) Комитета Министров Совета Европы 15 государствамчленам относительно мер, связанных с освещением средствами массовой информации избирательных кампаний (Принята 9 сентября 1999 г. на 678 заседании на уровне представителей министров) // Международные избирательные стандарты. Сб. документов // Отв. ред.: доктор юрид. наук В.И. Лысенко. М.: ЦИК России, 2009. С. 376-380. 
29. Рекомендация от 8 апреля 2003 г. № Rec (2003) 4 Комитета Министров Совета Европы «Об общих принципах борьбы с коррупцией при финансировании политических партий и избирательных кампаний» /f Международные избирательные стандарты. Сб. документов // Отв. ред.: доктор юрид. наук В.И. Лысенко. М.: ЦИК России, 2009. С. 380-384.

30. Рекомендация от 30 сентября 2004 г. № Rec (2004) 4 Комитета Министров Совета Европы 11 государствам-членам по правовым, организационным и техническим стандартам электронного голосования // Международные избирательные стандарты. Сб. документов // Отв. ред.: доктор юрид. наук В.И. Лысенко. М.: ЦИК России, 2009. С. 386-399.

31. Рекомендация 1595 (2003) Парламентской Ассамблеи Совета Европы «О Своде рекомендуемых норм при проведении выборов» (Страсбург, 30 января 2003 г.) // Международные избирательные стандарты. Сб. документов // Отв. ред.: доктор юрид. наук В.И. Лысенко. М.: ЦИК России, 2009. С. 320.

32. Руководство по наблюдению за выборами ОБСЕ / БДИПЧ (Варшава, 1997 г.) // OSCE. Рекомендации по анализу законодательной базы выборов. Варшава, 2001. C. 51-54.

33. Руководящие принципы запрета и роспуска политических партий Европейской комиссии «За демократию через право» (Венецианской комиссии) (Венеция, 10-11 декабря 1999 г.) // Совет Европы и Россия. 2001. № 1. С. 42-45.

34. Хартия Европейского союза об основных правах (Ницца, 7 декабря 2000 г.) // Международные избирательные стандарты. Сб. документов // Отв. ред.: кандидат юрид. наук А.А. Вешняков; науч. ред.: доктор юрид. наук В.И. Лысенко. М.: Издательство Весь Мир, 2004. С. 741-749.

\title{
Акты Содружества Независимых Государств
}

35. Конвенция о стандартах демократических выборов, избирательных прав и свобод в государствах-участниках Содружества Независимых Государств // Вестник ЦИК Российской Федерации. 2002. № 11. С. 218-231.

36. Декларация Межпарламентской Ассамблеи государств - участников СНГ «О принципах международного наблюдения за выборами и референдумами в государствах - участниках Содружества Независимых Государств» // Международные избирательные стандарты. Сб. документов // Отв. ред.: доктор юрид. наук В.И. Лысенко. М.: ЦИК России, 2009. С. 904-910.

\section{Нормативные правовые акты федеральных органов} государственной власти

\author{
Федеральные законьл
}

37. Федеральный закон от 19 мая 1995 г. № 82-Ф3 «Об общественных объединениях» (в ред. от 19 мая 2010 г.) // СЗ РФ. 1995. № 21. Ст. 1930; 1997. № 20. Ст. 2231; 1998. № 30. Ст. 3608; 2002. № 11. Ст. 1018; 2002. № 12. Ст. 1093; 2002. № 30. Ст. 3029; 2003. № 50. Ст. 4855; 2004 . № 27. Ст. 2711; 2004. № 45. Ст. 4377; 2006. № 3. Ст. 282; 2006. № 6. Ст. 636; 2008. № 30 (ч. 2). Ст. 3616; 2010. № 21. Ст. 2526.

38. Федеральный закон от 12 января 1996 г. (в ред. от 19 мая 2010 г.) № 7Ф3 «О некоммерческих организациях» //См. СЗ РФ. 1996. № 3. Ст. 145; 1998. № 48. Ст. 5849; 1999. № 28. Ст. 3473; 2002. № 52 (ч. 2). Ст. 5141; 2003. № 52 (ч. 1). Ст. 5031; 2006. № 3. Ст. 282; 2006. № 45. Ст. 4627; 2007. № 1 (ч. 1). Ст. 37; 2007. № 10. Ст. 1151; 2007. № 22. Ст. 2563; 2007. № 49. Ст. 6061; 2008. № 20. Ст. 2253; 
2008. № 30 (ч. 2). Ст. 3616; 2009. № 23. Ст. 2762; 2009. № 29. Ст. 3608; 2010. № 21. Ст. 2526.

39. Федеральный закон от 13 июня 1996 г. (в ред. от 19 мая 2010 г.) № 63-Ф3 «Уголовный кодекс Российской Федерации» // С3 РФ. 1996. № 25. Ст. 2954; 1999. № 7. Ст. 873; 1999. № 11. Ст. 1255; 1999. № 28. Ст. 3490; 2001. № 11. Ст. 1002; 2001. № 13. СТ. 1140; 2001. № 26. Ст. 2587; 2001. № 33 (ч. 1). СТ. 3424; 2001. № 53 (ч. 1). Ст. 5028; 2002. № 10. Ст. 966; 2002. № 19. Ст. 1795; 2002. № 44. Ст. 4298; 2003. № 15. Ст. 1304; 2003. № 27 (ч. 2). Ст. 2708; 2003. № 50. Ст. 4848; 2004. № 30. Ст. 3091; 2005. № 1 (ч. 1). Ст. 1; 2005. № 30 (ч. 1). Ст. 3104; 2005. № 52 (ч. 1). Ст. 5574; 2006. № 31 (ч. 1). Ст. 3452; 2007 . № 1 (ч. 1). Ст. 46; 2007. № 21. Ст. 2456; 2007. № 31. Ст. 4011; 2007. № 49. Ст. 6079; 2007. № 50. Ст. 6246; 2008. № 7. Ст. 551; 2008. № 15. Ст. 1444; 2008. № 20. Ст. 2251; 2008. № 30 (ч. 1). Ст. 3601; 2008. № 48. Ст. 5513; 2009. № 1. Ст. 29; 2009. № 7. Ст. 788; 2009. № 44. Ст. 5170; 2010. № 21. Ст. 2530 .

40. Федеральный закон от 26 ноября 1996 г. (в ред. от 9 ноября 2009 г.) № 138Ф3 «Об обеспечении конституционных прав граждан Россииской Федерации избирать и быть избранными в органы местного самоуправления» // Рос. газ. 1996. 4 декабря; 2006. 15 июля.

41. Федеральный закон от 6 октября 1999 г. (в ред. от 5 апреля 2010 г.) № 184Ф3 «Об общих принципах организации законодательных (представительных) и исполнительных органов государственной власти субъектов Российской Федерации» // С Р РФ. 1999. № 42. Ст. 5005; 2000. № 31. Ст. 3205; 2001. № 7. Ст. 608; 2002. № 19. Ст. 1792; 2002. № 30. Ст. 3024; 2002. № 50. Ст. 4930; 2003. № 27 (ч. 2). Ст. 2709; 2004. № 25. Ст. 2484; 2004. № 50. Ст. 4950; 2005. № 1 (ч. 1). Ст. 17; 2005. № 30 (ч. 1). Ст. $3104 ; 2006$. № 1. Ст. 10; 2006. № 1. Ст. 13; 2006. № 29. Ст. 3124; 2006. № 30. Ст. 3287; 2006. № 31 (ч. 1). Ст. 3427; 2006. № 31 (ч. 1). СТ. 3452; 2006. № 44. Ст. 4537; 2006. № 50. Ст. 5279; 2007. № 1 (ч. 1). Ст. 21; 2007. № 10. Ст. 1151; 2007. № 13. Ст. 1464; 2007. № 18. Ст. 2117; 2007. № 21. Ст. 2455; 2007. № 26. Ст. 3074; 2007. № 43. Ст. 5084; 2007. № 46. Ст. 5553; 2008. № 13. Ст. 1186; 2008. № 29 (ч. 1). СТ. 3418; 2008. № 30 (ч. 1). Ст. 3597; 2008. № 30 (ч. 2). Ст. 3616; 2008. № 48. Ст. 5516; 2008. № 49. Ст. 5747; 2008. № 52 (ч. 1). Ст. 6236; 2009. № 7. Ст. 772; 2009. № 29. Ст. 3612; 2010. № 15. Ст. 1736.

42. Федеральный закон от 11 июля 2001 г. (в ред. от 6 мая 2010 г.) № 95-Ф3 «О политических партиях» // С3 РФ. 2001. № 29. СТ. 2950; 2002. № 12. СТ. 1093; 2002. № 30. Ст. 3029; 2003. № 26. Ст. 2574; 2003. № 50. Ст. 4855; 2004. № 52 (ч. 1). Ст. 5272; 2005. № 1 (ч. 1). СТ. 9; 2005. № 30 (ч. 1). СТ. 3104; 2006. № 1. СТ. 13; 2006. № 29. Ст. 3124; 2007. № 1 (ч. 1). Ст. 37; 2007. № 18. Ст. 2118; 2008. № 30 (ч. 1). СТ. 3600; 2008. № 30 (ч. 2). Ст. 3616; 2008. № 45. Ст. 5146; 2009. № 14. Ст. 1577; 2009. № 44. Ст. 5170; 2010. № 19. Ст. 2288.

43. Федеральный закон от 30 декабря 2001 г. (в ред. от 19 мая 2010 г.) № 195-Ф3 «Кодекс Российской Федерации об административных правонарушениях» // Рос. газ. 2001. 31 декабря; 2002. 30 июля; 2002. 2 ноября; 2002. 31 декабря; 2003. 1 июля; 2003. 8 июля; 2003. 18 ноября; 2003. 16 декабря; 2003. 27 декабря; 2004. 31 июля; 2004. 25 августа; 2004. 30 декабря; 2005. 13 января; 2005. 11 марта; 2005. 24 марта; 2005. 26 июля; 2005. 28 июля; 2005. 8 декабря; 2005. 29 декабря; 2005. 31 декабря; 2006. 11 января; 2006. 8 февраля; 2006. 21 марта; 2006. 21 апреля; 2006. 11 мая; 2006. 8 июня; 2006. 20 июля; 2006. 29 июля; 2006. 18 октября; 2006. 9 ноября; 2006. 8 декабря; 2006. 12 декабря; 2006. 31 декабря; 2007. 5 апреля; 2007. 12 апреля; 2007. 31 июля; 2007. 1 августа; 2007. 24 октября; 2007. 14 ноября; 2007. 4 декабря; 2007. 15 декабря; 2008. 7 мая; 2008. 20 мая; 2008. 18 июля; 2008. 25 июля; 2008. 11 ноября; 2008. 9 декабря; 2008. 30 декабря; 2008. 31 декабря; 2009. 11 февраля; 2009. 22 июля; 2010. № 21. Ст. 2524.

44. Федеральный закон от 12 июня 2002 г. (в ред. от 22 апреля 2010 г.) № 67-Ф3 «Об основных гарантиях избирательных прав и права на участие в референдуме граждан Российской Федерации» // Рос. газ. 2002. 15 июня; 2002. 28 сентября; 2003. 25 июня; 2003. 8 июля; 2004. 9 июня; 2004. 14 августа; 2004. 31 августа; 2004. 15 декабря; 2005. 2 июля; 2005. 26 июля; 2006. 15 июля; 2006. 27 
июля; 2006. 7 декабря; 2007. 10 января; 2007. 2 февраля; 2007. 6 марта; 2007. 24 апреля; 2007. 11 мая; 2007. 1 августа; 2008. 25 июля; 2008. 28 ноября; 2008. 31 декабря; 2009. 11 февраля; 2009. 8 апреля; 10 июня; 21 июля; 2010. 26 апреля.

45. Федеральный закон от 25 июля 2002 г. (в ред. от 29 апреля 2008 г.) № 114-Ф3 «О противодействии экстремистской деятельности» // С3 РФ. 2002. № 30. Ст. 3031; 2006. № 31 (ч. 1). Ст. 3447; 2006. № 31 (ч. 1). Ст. 3452; 2007. № 21. Ст. 2457; 2007. № 31. Ст. 4008; 2008. № 18. Ст. 1939.

46. Федеральный закон от 10 января 2003 г. (в ред. от 22 апреля 2010 г.) № 19-Ф3 «О выборах Президента Российской Федерации» // Рос. газ. 2003. 16 января; 2005. 26 июля; 2006. 15 июля; 2006. 27 июля; 2007. 10 января; 2007. 11 мая; 2007. 1 августа; 2009. 11 февраля; 10 июня; 21 июля; 2010. 26 апреля.

47. Федеральный закон от 10 января 2003 г. (в ред. от 25 декабря 2008 г.)№ 20-Ф3 «О Государственной автоматизированной системе Российской Федерации «Выборы» // Рос. газ. 2003. 15 января; 2008. 30 декабря.

48. Федеральный закон от 19 июня 2004 г. № 54-Ф3 «О собраниях, митингах, демонстрациях, шествиях и пикетированиях» // СЗ РФ. 2004. № 25. Ст. 2485.

49. Федеральный закон от 18 мая 2005 г. (в ред. от 22 апреля 2010 г.) № 51 Ф3 «О выборах депутатов Государственной Думы Федерального Собрания Российской Федерации» // Рос. газ. 2005. 24 мая; 2006. 15 июля; 2006. 27 июля; 2007. 10 января; 2007. 11 мая; 2007. 25 июля; 2007. 1 августа; 2009. 11 февраля; 10 июня; 21 июля; 2010. 26 апреля.

50. Федеральный закон от 21 июля 2005 г. (в ред. от 26 апреля 2007 г.) № 93-Ф3 «О внесении изменений в законодательные акты Российской Федерации о выборах и референдумах и иные законодательные акты Российской Федерации» // Рос. газ. 2005. 26 июля.

51. Федеральный закон от 12 июля 2006 г. № 107-Ф3 «О внесении изменений в отдельные законодательные акты Российской Федерации в части отмены формы голосования против всех кандидатов (против всех списков кандидатов) // Рос. газ. 2006. 15 июля.

52. Федеральный закон от 5 декабря 2006 г. № 225-Ф3 «О внесении изменений в Федеральный закон «Об основных гарантиях избирательных прав и права на участие в референдуме граждан Российской Федерации» и Гражданский Процессуальный Кодекс Российской Федерации» // С3 РФ. 2006. № 50. Ст. 5303.

53. Федеральный закон от 9 февраля 2009 г. № 3-Ф3 «О внесении изменений в отдельные законодательные акты Российской Федерации в связи с отменой избирательного залога при проведении выборов» // СЗ РФ. 2009. № 7. Ст. 771.

54. Федеральный закон от 28 апреля 2009 г. № 75-Ф3 «О внесении изменений в Федеральный закон «О политических партиях» в связи с поэтапным снижением минимальной численности членов политических партий» // Рос. газ. 2009. 5 мая.

55. Федеральный закон от 12 мая 2009 г. № 94-Ф3 «О внесении изменений в отдельные законодательные акты Российской Федерации в связи с повышением представительства избирателей в Государственной Думе Федерального Собрания Российской Федерации» // Рос. газ. 2009. 15 мая.

56. Федеральный закон от 3 июня 2009 г. № 108-Ф3 «О внесении изменений в отдельные законодательные акты Российской Федерации в связи с сокращением количества подписей избирателей в поддержку выдвижения федеральных списков кандидатов на выборах депутатов Государственной Думы Федерального Собрания Российской Федерации и уточнением оснований для регистрации кандидатов, списков кандидатов на выборах в органы государственной власти и органы местного самоуправления» // Рос. газ. 2009. 10 июня.

57. Федеральный закон от 9 ноября 2009 г. № 250-Ф3 «О внесении изменений в статью 3 приложения к Федеральному закону «Об обеспечении 
конституционных прав граждан Российской Федерации избирать и быть избранными в органы местного самоуправления» и статью 4 Федерального закона «Об основных гарантиях избирательных прав и права на участие в референдуме граждан Российской Федерации» // Рос. газ. 2009. 11 ноября.

58. Федеральный закон от 22 апреля 2010 г. № 63-Ф3 «О внесении изменений в отдельные законодательные акты Российской Федерации в связи с повышением представительства избирателей в законодательных (представительных) органах государственной власти субъектов Российской Федерации и освобождением от сбора подписей политических партий, списки кандидатов которых получили депутатские мандаты в законодательных (представительных) органах государственной власти субъектов Российской Федерации» // С3 РФ. 2010. № 17. Ст. 1986.

59. Федеральный закон от 31 мая 2010 г. № 112-Ф3 «О внесении изменений в Федеральный закон «Об основных гарантиях избирательных прав и права на участие в референдуме граждан Российской Федерации» в связи с изменением порядка досрочного голосования на выборах в органы местного самоуправления» // Рос. газ. 2010. 4 июня.

60. Федеральный закон от 4 июня 2010 г. № 118-Ф3 «О внесении изменений в Федеральный закон «Об общих принципах организации законодательных (представительных) и исполнительных органов государственной власти субъектов Российской Федерации» в связи с повышением представительства избирателей в законодательных (представительных) органах государственной власти субъектов Российской Федерации и установлением требований к условиям осуществления депутатской деятельности» // Рос. газ. 2010.9 июня.

\section{Законы Российской Федерации}

61. Закон Российской Федерации от 18 апреля 1991 г. (в ред. от 29 декабря 2009 г.) № 1026-1 «О милиции»// Ведомости СНД и ВС РСФСР. 1991. № 16. С т. 503; Ведомости СНД и ВС РСФСР. 1993. № 10. Ст. 360; Ведомости СНД и ВС РСФСР. 1993. № 32. Ст. 1231; СЗ РФ. 1996. № 25. СТ. 2964; 1999. № 14. СТ. 1666; 1999. № 49. Ст. 5905; 2000. № 31. Ст. 3204; 2000. № 46. Ст. 4537; 2001. № 31 . СТ. 3172; 2001. № 32. Ст. 3316; 2002. № 18. Ст. 1721; 2002. № 27. СТ. 2620; 2002. № 30. Ст. 3029; 2003. № 2. Ст. 167; 2003. № 27 (ч. 1). Ст. 2700; 2003. № 28. Ст. 2880; 2003. № 50. Ст. 4847; 2004. № 30. Ст. 3087; 2004. № 35. Ст. 3607; 2005. № 13. Ст. $1078 ; 2005$. № 14 . Ст. 1212; 2005 . № 19. Ст. 1752; 2006. № 24. С т. 2555; 2006. № 31 (ч. 1). Ст. 3420; 2006. № 31 (ч. 1). СТ. 3425; 2006. № 52 (ч. 1). Ст. 5498; 2007. № 10. Ст. 1151; 2007. № 41. СТ. 4845; 2008. № 30 (ч. 2). СТ. 3616; 2008. № 52 (ч. 1). СТ. 6235; 2008. № 52 (ч. 1). Ст. 6248; 2010. № 1. Ст. 4.

62. Закон Российской Федерации от 27 декабря 1991 г. (с изм. от 9 февраля 2009 г.) № 2124-1 «О средствах массовой информации» // Рос. газ. 1992. 8 февраля; 1995. 14 января; 1995. 8 июня; 1995. 26 июля; 1996. 10 января; 1998. 5 марта; 2000. 22 июня; 2000.'8 августа; 2001. 9 августа; 2002. 26 марта; 2002. 30 июля; 2003. 8 июля; 2003. 16 декабря; 2004. 1 июля; 2004. 31 августа; 2004. 5 ноября; 2005. 26 июля; 2006. 29 июля; 2006. 18 октября; 2007. 1 августа; 2008. 30 декабря; 2009. 11 февраля.

63. Закон Российской Федерации от 17 января 1992 г. (в ред. от 28 ноября 2009 г.) № 2202-1《О прокуратуре Российской Федерации» // Рос. газ. 1992. 18 февраля; 1995. 25 ноября; 1999. 17 февраля; 1999. 24 ноября; 2000. 5 января; 2001. 30 декабря; 2002. 3 июля; 2002. 30 июля; 2003. 1 июля; 2004. 31 августа; 2005. 16 июля; 2005. 9 ноября; 2007. 6 марта; 2007. 8 июня; 2007. 1 августа; 2008. 30 декабря; 2009. 21 июля.

64. Закон Российской Федерации от 5 марта 1992 г. (в ред. от 26 июня 2008 г.) № 2446-1 «О безопасности»// Рос. газ. 1992. 6 мая; 1993. 10 января; 2002. 30 июля; 2005. 11 марта; 2006. 27 июля; 2007. 6 марта; 2008. 28 июня. 


\section{Постановления Государственной Думы и Совета Федерации Федерального Собрания}

65. Постановление Государственной Думы Федерального Собрания Российской Федерации от 16 апреля 1998 г. N 2394-II ГД «О создании Комиссии Государственной Думы Федерального Собрания Российской Федерации по проверке соблюдения избирательного законодательства в ходе подготовки и проведения выборов мэра города Нижнего Новгорода» // СЗ РФ. 1998. № 17. Ст. 1897.

66. Постановление Государственной Думы Федерального Собрания Российской Федерации от 23 октября 2002 г. № 33170-ПІІ ГД «О комиссии Государственной Думы Федерального Собрания Российской Федерации по изучению подготовки и проведения выборов депутатов Законодательного Собрания города Санкт-Петербурга» // СЗ РФ. 2002. № 44. Ст. 4334.

67. Постановление Совета Федерации Федерального Собрания Российской Федерации от 3 декабря 1997 г. № 403-СФ «О запросе Совета Федерации Федерального Собрания Российской Федерации в Конституционный суд Российской Федерации о проверке конституционности положений пунктов 3 и 4 статьи 13, пункта 3 статьи 19 и пункта 2 статьи 58 Федерального закона «Об основных гарантиях избирательных прав и права на участие в референдуме граждан Российской Федерации» // Рос. газ. 1997. 17 декабря.

68. Постановление Совета Федерации Федерального Собрания Российской Федерации от 10 декабря 2003 г. N 337-СФ «О назначении выборов Президента Российской Федерации» // Рос. газ. 2003. 11 декабря.

69. Постановление Совета Федерации Федерального Собрания Российской Федерации от 26 ноября 2007 г. № 550-СФ «О назначении выборов Президента Российской Федерации» // Рос. газ. 2007. 28 ноября.

\section{Указы Президента Российской Федеращии}

70. Указ Президента Российской Федерации от 23 августа 1994 г. № 1723 «О разработке и создании Государственной автоматизированной системы Российской Федерации «Выборы» // СЗ РФ. 1994. № 18. Ст. 1723.

71. Указ Президента Российской Федерации от 28 февраля 1995 г. № 227 «Об обеспечении создания, функционирования и развития Государственной автоматизированной системы Российской Федерации «Выборы» // Рос. газ. 1995. 11 марта.

72. Указ Президента Российской Федерации от 28 февраля 1995 г. № 228 «О федеральной целевой программе повышения правовой культуры избирателей и организаторов выборов в Российской Федерации» // Рос. газ. 1995. 11 марта.

73. Указ Президента Российской Федерации от 23 марта 1995 г. (в ред. от 3 ноября 2004 г.) № 310 «О мерах по обеспечению согласованных действий органов государственной власти в борьбе с проявлениями фашизма и иных форм политического экстремизма в Российской Федерации» // Рос. газ. 1995. 25 марта; СЗ РФ. 2004. № 45. Ст. 4414.

74. Указ Президента Российской Федерации от 17 июля 1996 г. № 1038 «О мерах по обеспечению конституционных прав граждан на участие в выборах законодательного (представительного) органа государственной власти Кемеровской области» // СЗ РФ. 1996. № 30. Ст. 3604.

75. Указ Президента Российской Федерации от 30 мая 1997 г. № 535 (в ред. от 25 ноября 2003 г.) «Об обеспечении избирательных прав военнослужащих, 
сотрудников органов внутренних дел Российской Федерации, федеральных органов налоговой полиции и работников органов прокуратуры Российской Федерации» // СЗ РФ. 1997. № 22. Ст. 2572; 2003. № 16. Ст. 1508; 2003. № 48. Ст. 4659.

76. Указ Президента Российской Федерации от 2 сентября 2003 г. № 1030 «O назначении выборов депутатов Государственной Думы Федерального Собрания Российской Федерации нового созыва» // Рос. газ. 2003. 3 сентября.

77. Указ Президента Российской Федерации от 2 сентября 2007 г. № 1144 «О назначении выборов депутатов Государственной Думы Федерального Собрания Российской Федерации нового созыва» // Рос. газ. 2007. 5 сентября.

78. Указ Президента Российской Федерации от 29 февраля 2008 г. № 285 «Об утверждении Положения о выборах депутатов Законодательного Собрания Забайкальского края первого созыва» // Рос. газ. 2008. 8 марта.

79. Указ Президента Российской Федерации от 12 мая 2009 г. № 537 «Об утверждении Стратегии национальной безопасности Российской Федерации до 2020 года» // Рос. газ. 2009. 19 мая.

\section{Постановления Правительства Российской Федеращчии}

80. Постановление Правительства Российской Федерации от 17 мая 1995 г. № 482 «О Федеральной целевой программе повышения правовой культуры избирателей и организаторов выборов в Российской Федерации» // С3 РФ. 1995. № 22. Ст. 2063.

81. Постановление Правительства Российской Федерации от 18 декабря 1995 г. № 1242 «О Федеральной целевой программе развития Государственной автоматизированной системы Российской Федерации «Выборы» на 1996-2000 годы» // СЗ РФ. 1995. № 52. Ст. 5166.

82. Постановление Правительства Российской Федерации от 25 августа 1999 г. № 937 «О содействии избирательным комиссиям в организации подготовки и проведения выборов депутатов Государственной Думы Федерального Собрания Российской Федерации» // Ведомости Федерального Собрания. 1999. № 26. 11 сентября.

83. Постановление Правительства Российской Федерации от 13 января 2000 года № 32 «О содействии избирательным комиссиям в организации подготовки и проведения выборов Президента Российской Федерации» // Рос. газ. 2000. 13 января.

84. Постановление Правительства Российской Федерации от 2 июля 2003 г. № 391 «О порядке выдачи гражданам Российской Федерации, находящимся в местах содержания под стражей подозреваемых и обвиняемых, справки для участия в выборах или в референдуме»// СЗ РФ. 2003. № 27 (ч. 2). Ст. 2812.

85. Постановление Правительства Российской Федерации от 5 сентября 2003 года № 555 «О мерах по содействию избирательным комиссиям в организации подготовки и проведения выборов депутатов Государственной Думы Федерального Собрания Российской Федерации и Президента Российской Федерации» // С3 РФ. 2003. № 37. Ст. 3596.

86. Постановление Правительства Российской Федерации от 17 сентября 2007 года № 589 «О мерах по оказанию содействия избирательным комиссиям в реализации их полномочий при подготовке и проведении выборов депутатов Государственной Думы Федерального Собрания Российской Федерации и Президента Российской Федерации» // Рос. газ. 2007. 26 сентября. 
87. Постановление Центральной избирательной комиссии Российской Федерации от 23 мая 2001 г. № 131/ 1266-3 «О ходе работы в субъектах Российской Федерации по приведению регионального законодательства о выборах в соответствие с федеральным законодательством» // Сборник законодательных и иных нормативных правовых актов, решений Конституционного Суда Российской Федерации по вопросам выборов и референдумов в Российской Федерации. М.: ЦИК Российской Федерации. 2003. C. $159-162$.

88. Постановление Центральной избирательной комиссии Российской Федерации от 30 ноября 2001 г. № 144/1320-3 «О содействии Центральной избирательной комиссии, органов исполнительной власти, правоохранительных органов избирательным комиссиям субъектов Российской Федерации в организации проведения выборов»/ // Вестник ЦИК Российской Федерации. 2001. № 10. С. 10-12.

89. Постановление Центральной избирательной комиссии Российской Федерации от 23 июля 2003 г. (в ред. от 28 февраля 2007 г.) № 19/137-4 «О Положении об обеспечении безопасности информации в Государственной автоматизированной системе Российской Федерации «Выборы» // Вестник ЦИК РФ. 2007. № 3.

90. Постановление Центральной избирательной комиссии Российской Федерации от 25 апреля 2007 г. (в ред. от 19 ноября 2008 г.) № 5/45-5 «О Положении о Контрольно-ревизионной службе при Центральной избирательной комиссии Российской Федерации» // Вестник ЦИК Российской Федерации. 2007. № 5; 2008. № 12.

\section{Нормативные правовые акты министерств и ведомств Российской Федерациии}

91. Приказ Генеральной прокуратуры Российской Федерации от 7 декабря 2007 г. № 195 «Об организации прокурорского надзора за исполнением законов, соблюдением прав и свобод человека и гражданина»//Законность. 2008. № 3.

92. Приказ Министра внутренних дел Российской Федерации от 21 февраля 2005 г. № 108 «Об объявлении Соглашения о взаимодействии Центральной избирательной комиссии Российской Федерации и Министерства внутренних дел Российской Федерации». [Текст приказа не опубликован.]

93. Приказ Министра внутренних дел Российской Федерации от 26 сентября 2007 г. № 835 «О порядке исполнения органами внутренних дел Россииской Федерации представлений избирательных комиссий» [Текст приказа не опубликован.]

94. Приказ Федеральной налоговой службы от 10 августа 2007 г. № MМ-304/474 «Об организации работы по оказанию содействия Центральной избирательной комиссии Российской Федерации в проверке достоверности сведений о размере и об источниках доходов, имуществе, принадлежащем кандидату на праве собственности, о вкладах в банках, ценных бумагах, представляемых кандидатами в депутаты Государственной Думы Федерального Собрания Российской Федерации пятого созыва». [Текст приказа не опубликован.]

\section{Нормативные правовые акты субъектов Российской Федерации}

\section{Законы субъектов Российской Федерации}

95. Закон Архангельской области от 8 ноября 2006 г. (в ред. от 24 июня 2009 г.) № 268-13-О3 «О выборах в органы местного самоуправления в Архангельской области»// http://www.arkhangelsk.izbirkom.ru 
96. Закон Владимирской области от 13 февраля 2003 г. (в ред. от 11 марта 2010 г.) № 10-О3 «Избирательный кодекс Владимирской области» // http://www.vladimir.izbirkom.ru

97. Закон Волгоградской области от 6 декабря 2006 г. (в ред. от 19 июня 2009 г.) № 1373-ОД «О выборах в органы местного самоуправления Волгоградской области» // http://www.volgograd.izbirkom.ru

87-O3 98. Закон Воронежской области от 27 июня 2007 г. (в ред. от 11 ноября 2009 г.) № http://www.voronezh.vybory.izbirkom.ru

99. Закон Забайкальского края от 5 октября 2009 г. № 230-33К «Об избирательной комиссии Забайкальского края// http://www.chita.izbirkom.ru

100. Закон Ивановской области от 13 июля 2007 г. (в ред. от 26 ноября 2009 г.) № 98-О3 «О системе избирательных комиссий в Ивановской области» // http://www.ivanovo.vybory.izbirkom.ru

101. Закон Кабардино-Балкарской Республики от 5 августа 2008 г. (в ред. от 21 июля 2009 г.) № 56-Р3 «О выборах депутатов парламента Кабардино-Балкарской Республики» // http://www.kabardin-balkar.izbirkom.ru

102. Закон Курской области от 3 декабря 2009 г. № 106-ЗКО «Кодекс Курской области о выборах и референдумах» // http://www.kursk.izbirkom.ru

103. Закон Псковской области от 1 августа 2003 г. (в ред. от 5 ноября 2009 г.) № 295О3 «Избирательный кодекс Псковской области» // http://www.pskov.izbirkom.ru.

104. Закон Псковской области от 26 июля 2007 г. (в ред. от 4 октября 2007 г.) № 697-О3 «О территориальных избирательных комиссиях в Псковской области, обладающих правами юридического лица» // http://www.pskov.izbirkom.ru

105. Закон Республики Карелия от 5 июня 2006 г. № 989-3РК «О перечне труднодоступных и отдаленных местностей в Республике Карелия» // http://www.karel.izbirkom.ru

106. Закон Тульской области от 9 июня 2008 г. № 1024-3ТО «О видах избирательных систем, порядке и условиях их применения при проведении муниципальных выборов в Тульской области» // http://www. tula.izbirkom..ru

107. Закон Чувашской Республики от 4 июня 2007 г. № 14 «О противодействии коррупции» // СЗ Чувашской Республики. 2007. № 5. Ст. 253.

108. Избирательный кодекс Амурской области от 17 сентября 2003 г. (в ред. от 26 сентября 2008 г.) № 239-O3 // http://www.amur.izbirkom.ru

109. Избирательный кодекс Белгородской области от 7 мая 2007 г. (в ред. от 2 февраля 2009 г.) № 108 // http://wWw.belgorod.izbirkom.ru

110. Избирательный кодекс Костромской области от 30 декабря 1998 г. (в ред. от 22 июня 2010 г.) № 39 // http://www.kostroma.1zbirkom.ru/

111. Избирательный кодекс Приморского края от 22 июля 2003 г. (в ред. от 28 июля 2009 г.) № 62-K3 // http://www.primorsk.vybory.izbirkom.ru

112. Избирательный кодекс Республики Татарстан от 7 мая 2007 г. (в ред. от 26 декабря 2007 г.) № 21-3РТ // http://www.tatarstan.vybory.1zbirkom.ru/

113. Избирательный кодекс Свердловской области от 24 апреля 2003 г. (в ред. от 27 ноября 2009 г.) № 10-O3 // http://Www.sverdlovsk.vybory.izbirkom.ru

114. Избирательный кодекс Тверской области от 25 марта 2003 г. (в ред. от 28 мая 2009 г.) // http://www.tver.izbirkom.ru

115. Избирательный кодекс (Закон) Тюменской области от 3 июня 2003 г. (в ред. от 7 октября 2009 г.) № 139 // http://www.tyumen.vybory.izbirkom.ru

116. Избирательный кодекс Хабаровского края от 26 ноября 2003 г. (в ред. от 25 ноября 2009 г.) № 154 // http://WWw.khabarovsk.vybory.izbirkom.ru 
117. Кодекс Алтайского края о выборах, референдуме, отзыве депутатов от 8 июля 2003 г. (в ред. от 3 июля 2009 г.) № 35-3C // http://www.altai_terr.izbirkom.ru

118. Кодекс Республики Башкортостан о выборах от 6 декабря 2006 г. (в ред. от 16 ноября 2007 г.) № 380-3 // http://www.bashkortostan.izbirkom.ru

\section{Нормативные правовые актыл органов исполнительной власти субъектов Российской Федерации}

119. Указ Главы Республики Коми от 28 марта 2006 г. № 37 «Об организации и осуществлении регистрации (учета) избирателей, участников референдума на территории Республики Коми».

120. Указ Президента Удмуртской Республики от 1 августа 2006 года № 113 «О содействии избирательным комиссиям в подготовке и проведении выборов депутатов представительных органов муниципальных районов».

121. Постановление Губернатора Курской области от 13 февраля 2006 г. № 76 «О мерах по реализации Положения о Государственной системе регистрации (учета) избирателей, участников референдума на территории Курской области».

122. Постановление Кабинета Министров Республики Татарстан от 12 октября 2007 г. № 550 «О содействии избирательным комиссиям в организации подготовки и проведения выборов депутатов Государственной Думы Федерального Собрания Российской Федерации и Президента Российской Федерации».

123. Постановление Правительства Саратовской области от 22 июля 2008 г. № 294-II «О содействии избирательным комиссиям в Саратовской области в организации подготовки и проведения выборов в органы местного самоуправления 12 октября 2008 года».

124. Постановление Правительства Москвы от 15 марта 2005 г. № 139-ПП «Об оказании содействия в организационном и материально-техническом обеспечении повторных и дополнительных выборов депутатов муниципальных собраний внутригородских муниципальных образований в г. Москве»// Вестник Мэра и Правительства Москвы. 2005. 6 апреля.

\section{Нормативные правовые акты избирательных комиссий субъектов Российской Федераџиии}

125. Постановление Центральной избирательной комиссии Республики Башкортостан от 20 августа 2008 года № Ц- 4/3-4 «О Контрольно-ревизионной службе при Центральной избирательной комиссии Республики Башкортостан» // http://www.bashkortostan.izbirkom.ru

126. Постановление избирательной комиссии Калужской области» от 28 марта 2007 г. № 28/6-III «О мерах по обеспечению безопасности информации, обрабатываемой в ГАС РФ «Выборы» в избирательной комиссии Калужской области» // http://www.kaluga.izbirkom.ru

127. Постановление Избирательной комиссии Костромской области от 6 сентября 2007 г. № 16 «О Контрольно-ревизионной службе при избирательной . комиссии Костромской области» // http://www.kostroma.izbirkom.ru

128. Постановление избирательной комиссии Липецкой области от 14 августа 2008 года № 35/313-4 «О Примерном Положении о контрольноревизионной службе при избирательной комиссии муниципального образования» // http://www.lipetsk.izbirkom.ru 
129. Решение избирательной комиссии Приморского края от 29 июля 2009 г. № 566/110 «Об утверждении Порядка организации и проведения антикоррупционной экспертизы нормативных правовых актов избирательной комиссии Приморского края» // http://www.primorsk.vybory.izbirkom.ru

\section{Нормативные правовые акты иностранных государств}

130. Конституции зарубежных государств: США, Великобритания, Франция, Германия, Италия, Испания, Греция, Япония, Канада / Сост. В.В. Маклаков. М.: Бек, 1997.

131. Bundeswahlgesetz (D) // BGB1. I. S.1288, 1594/1993; BGB1. I. S. 674/2005.

132. Bundesgesetz bber die politischen Rechte der Auslandschweizer // Bundesgesetz BGBl 1975 I 1317.

133. Bundesgesetz sber die politischen Rechte // Bundesgesetz BGB1 1993 III 445.

134. Bundeswahlordnung (D) // BGB1. I. S.1376/2002; BGBl. I. S.1951/2005.

135. Bundesprasidentenwahlgesetz 1971 // Bundesgesetz BGB1. Nr. 57/1971; BGBl. I Nr. 28/2007.

136. Electoral Fraud (Northern Ireland) Act 2002 // http://www.electoralcommission.org.uk/templates/search/document

137. Electoral Registration (Northern Ireland) Act 2005 // http://www.electoralcommission.org.uk/templates/search/document

138. Electoral Administration Act 2006 // http://www.electoralcommission.org.uk/templates/search/document

139. Europawahlordnung 1996 (O) // BGBl. Nr. 117/1996; BGB1. I Nr. 28/2007.

140. Federal Elections Campaigns. United States Code. Title 2. Chapter 14.

141.Presidential Elections and Vacancies. United States Code. Title 3. Chapter 1. 142.Representation of the People Act

\section{Судебная практика}

\section{Постановления Европейского суда по правам человека}

143. Постановление Европейского суда по правам человека от 8 июля 1986 г. по делу «Лингенс (Lingens) против Австрии» // Международные избирательные стандарты. Сб. документов. М.: Издательство Весь Мир, 2004. С. 653-659.

144. Постановление Европейского суда по правам человека от 23 мая 1991 г. по делу «Обершлик (Oberschlick) против Австрии» // Международные избирательные стандарты. Сб. документов. М.: Издательство Весь Мир, 2004. С. 666-678.

145. Постановление Европейского суда по правам человека от 23 апреля 1992 г. по делу «Кастеллс (Castells) против Испании» // Международные избирательные стандарты. Сб. документов. М.: Издательство Весь Мир, 2004. С. 678-687.

146. Постановление Европейского суда по правам человека от 26 сентября 1995 г. по делу «Фогт (Vogt) против Германии» // Международные избирательные стандарты. Сб. документов. М.: Издательство Весь Мир, 2004. С. 687-703. 
147. Постановление Европейского суда по правам человека от 25 мая 1998 г. «Социалистическая партия и другие против Турции» // Европейский суд по правам человека. Избранные решения. М.: Норма, 2000. Т. 2. С. 496-508.

148. Постановление Европейского суда по правам человека по делу «Объединенная коммунистическая партия и другие против Турции» от 30 января 1998 г. // http://www.echr.coe.int

149. Постановление Европейского суда по правам человека от 30 марта 2004 г. «Дело Херст (Hirst) против Соединенного Королевства» // Международные избирательные стандарты. Сб. документов. М.: Издательство Весь Мир, 2004. С. 738741.

\section{Судебные постановления судов общей юрисдикиии Российской Федеращии}

150. Определение Судебной коллегии по гражданским делам Верховного Суда Российской Федерации от 4 апреля 2003 г. по делу № 53-ГО3-8 о решении Красноярского краевого суда о расформировании Избирательной комиссии Красноярского края // Вестник ЦИК РФ. 2003. № 3.

151. Определение Судебной коллегии по гражданским делам Верховного Суда Российской Федерации от 9 марта 2006 г. № 1-ГО6-9 по кассационной жалобе Тутова А.Н. на решение Архангельского областного суда от 22 февраля 2006 года, которым отказано в удовлетворении его заявления об отмене постановления окружной избирательной комиссии по одномандатному избирательному округу $\mathrm{N} 3$ об отказе в его регистрации кандидатом в депутаты Архангельского областного Собрания депутатов.

152. Определение Судебной коллегии по гражданским делам Верховного Суда Российской Федерации от 5 марта 2007 г. № 78-ГО7-13 об отказе в удовлетворении заявления Регионального отделения политической партии «Социалистическая единая партия России» в Санкт-Петербурге об отмене решения Санкт-Петербургской избирательной комиссии от 26 января 2007 г. № 77-1.2 об отказе в регистрации списка кандидатов, выдвинутого Региональным отделением политической партии «Социалистическая единая партия России».

153. Решение Верховного Суда Российской Федерации от 2 марта 2006. г. № ГКПИ06-69 по заявлению Квачкова В.В. об отмене Постановления Центральной избирательной комиссии Российской Федерации от 9 декабря 2005 г. № 162/1065-4 «Об установлении результатов повторных дополнительных выборов депутата Государственной думы Федерального Собрания Российской Федерации четвертого созыва по Преображенскому одномандатному избирательному округу № 199 г. Москвы».

154. Решение Верховного Суда Российской Федерации от 9 ноября 2007 г. № ГКПИ07-1426 по заявлению Центральной избирательной комиссии Российской Федерации об отмене регистрации кандидата в депутаты Государственной Думы Федерального Собрания Российской Федерации пятого созыва Наджаряна С.Н., включенного в зарегистрированный федеральный список кандидатов, выдвинутый политической партией «Либерально-демократическая партия России».

155. Решение Верховного Суда Российской Федерации от 24 ноября 2007 г. № ГКПИ07-1533 по заявлению Центральной избирательной комиссии Российской Федерации об отмене регистрации кандидата в депутаты Государственной Думы Федерального Собрания Российской Федерации пятого созыва Шагиняна А.М., включенного в зарегистрированный федеральный список кандидатов, выдвинутый политической партией «Либерально-демократическая партия России».

156. Решение Верховного Суда Российской Федерации от 26 ноября 2007 г. № ГКПИ07-1535 по заявлению политической партии «Аграрная партия России» об отмене регистрации кандидата в депутаты Государственной Думы Федерального Собрания Российской Федерации пятого созыва Кузьмина Д.С., включенного в зарегистрированный федеральный список кандидатов, выдвинутый политической партией «Справедливая Россия: Родина/Пенсионеры/Жизнь». 
157. Решение Верховного Суда Российской Федерации от 28 декабря 2007 года по заявлению В.К. Буковского об отмене постановления Центральной избирательной комиссии Российской Федерации от 22 декабря 2007 г. № 80/644-5 «Об отказе в регистрации группы избирателей, созданной для поддержки самовыдвижения Буковского В.К. кандидатом на должность Президента Российской Федерации, и ее уполномоченных представителей».

158. Решение Верховного Суда Российской Федерации от 5 февраля 2008 г. по делу № ГКПИ08-268 об отмене Постановления Центральной избирательной комиссии Российской Федерации от 27 января 2008 года № 92/710-5 «Об отказе M.M. Касьянову в регистрации кандидатом на должность Президента Российской Федерации» и обязании Центральную избирательную комиссию Российской Федерации зарегистрировать кандидатом на должность Президента Российской Федерации М.М. Касьянова.

159. Решение Верховного Суда Российской Федерации от 3 июля 2008 г. по делу № ГКПИ08-1472 по заявлению политической партии «Союз правых сил», Белых Н.Ю., Прохорова В.Ю и Казакова С.П. о признании результатов выборов депутатов Государственной Думы Федерального Собрания Российской Федерации пятого созыва, состоявшихся 2 декабря 2007 г., недействительными.

160. Решение Московского городского суда от 26 ноября 2005 г. по делу № 3$562 / 2005$ об отмене регистрации городского списка кандидатов в депутаты Московской городской Думы четвертого созыва, выдвинутого региональным отделением политической партии «Родина» в г. Москве.

161.Определение Московского областного суда от 28 февраля 2006 г. по делу № 33-2481 об отмене решения Климовского городского суда об отказе в удовлетворении заявления Центральной избирательной комиссии Российской Федерации о расформировании избирательной комиссии муниципального образования «Город Климовск Московской области» // Вестник ЦИК РФ. 2006. № 3.

162.Решение Светлогорского городского суда Калиниградской области от 19 ноября 2007 г. по заявлению избирательной комиссии муниципального образования «Пионерский городской округ» об отмене регистрации кандидатом в депутаты Степанова Н.А.

163. Решение Кировского районного суда г. Санкт-Петербурга от 18 февраля 2010 г. по делу № 2-1144/10 об отмене регистрации Трусканова Г.Б. кандидатом в депутаты Муниципального совета муниципального образования муниципальный округ «Автово» четвертого созыва по многомандатному избирательному округу № 8.

\section{Литература}

164. Авакьян C.A. Государственно-правовая ответственность // Советское государство и право. 1975. № 10. С. 16-24.

165. Авакьян C.A. Политический плюрализм и общественные объединения в Российской Федерации. Конституционно-правовые основы. М.: Рос. юрид. изд. дом, 1996. 359 с.

166. Авакьян C.A. Традиции и новшества в законодательстве о выборах в Государственную Думу / Законодательство. 1999. № 9-10. С. 48-58; С. $43-53$.

167. Авакьян C.A. Политические отношения и конституционное регулирование в современной России: проблемы и перспективы // Журнал российского права. 2003. № 11. С. 43-54.

168. Авакьян C.A. Пробелы и дефекты в конституционном праве и пути их устранения // Конституционное и муниципальное право. 2007. № 8. С. 3-12.

169. Авдеенкова М.П., Дмитриев Ю.А. Интересы избирателей - на первое место // Право и политика. 2001. № 9. С. 140-144. 
170. Автономов А.С. Избирательная власть. М.: Права человека, 2002. 88 с.

171. Автономов А.С., Веденеев Ю.А., Луговой В.В. Сравнительное избирательное право. М.: Норма, 2003. 208 с.

172. Алехичева Л.Г., Постников А.Е. Признание недействительными итогов голосования и результатов выборов: правовые проблемы // Журнал российского права. 2001. № 6. С. 25-36.

173. Бабурин С.Н. Территориальное, социально-экономическое, политикоправовое единство и перспективы развития российского федерализма / Российский путь: утраты и обретения. М.: Новатор, 1997. 460 с.

174. Бабурин С.Н. Конституция России: 5 лет по пути к федерализму и местному самоуправлению // Материалы круглого стола «5 лет Конституции Российской Федерации: по пути к федерализму и местному самоуправлению». М.: Городец, 1999. С. 8-13.

175. Бабурин С.Н. Государствоведение: научные труды. М.: Юнити-Дана, 2010. $711 \mathrm{c}$.

176. Бабурин С.Н. Российский путь / Современный русский консерватизм: научные труды. М.: Юнити-Дана, 2010. С. 87-143.

177. Бабурин C.H. Россия конца XX века: парламентаризм против народовластия / Современный русский консерватизм: научные труды. М.: ЮнитиДана, 2010. С. 253-273.

178. Бабурин С., Голик Ю., Шашвиашвили И., Энгвер Н. Агенты влияния // Советская Россия. 1992. 21 ноября.

179. Бабурин С.Н., Голик Ю.В., Карасев В.И. Коррупция - наиболее опасный вектор деградации общества: Материалы к размышлению. М., 2004. 250 c.

180. Бабурин С.Н., Голик Ю.В., Карапетян Л.М. Партизация государства как путь деградации общества / Актуальные проблемы современного российского государствоведения: сб. научных трудов. Вып. 2. / Под ред. С.Н. Бабурина М.: Изд-во РГТЭУ, 2009. С. 270-282.

181. Бабурин С.Н., Костенко В.И. Российская политическая культура: прошлое, настоящее, будущее // Право и государство: теория и практика. 2007. № 7. C. $109-115$.

182. Бабурин С.Н., Урсул А.Д. Стратегия национальной безопасности: безопасность через устойчивое развитие // Национальные интересы. 2010. № 2.

183. Барабашев Г.В., Шеремет К.Ф. Непосредственная демократия в СССР. М.: Знание, 1984. 64 с.

184. Барииц И.Н. Федеральное и региональное законодательство: требование соответствия // Право и политика. 2001. № 3. С. 17-25.

185. Барции И.Н. О единстве государственной власти в Российской Федерации // Законодательство. 2001. № 9. С. 37-46.

186. Биктагиров P.T. Субъект избирательного права Российской Федерации: конституционно-правовое исследование. Автореф. дис. ... д-ра юрид. наук. М., 2010. 55 с.

187. Боброва H.A. Конституционный строй и конституционализм в Российской Федерации (Проблемы методологии, теории, практики). Дис. ... д-ра юрид. наук. Самара, 2003. 330 с.

188. Богданова Н.A. Конституционные права и свободы: концептуальные подходы, нормативное воплощение и проблемы реализации в России // Конституционный вестник: Проблемы реализации Конституции. № 1. М.: Российский фонд конституционных реформ, 2008. С. 95-103. 
189. Болехивская А.Д. Правовая охрана Конституции Российской Федерации Дис. ... канд. юрид. наук. Волгоград, 2006. 201 с.

190. Бондарь Н.С. Конституционный строй Российской Федерации и роль Конституционного Суда в его защите // Современный конституционализм. Тирасполь, 2006. № 1. С. 20-31.

191. Борисов И.Б. Электоральный суверенитет или внешнее управление // Профиль. 2008. № 22. С. 22-23.

192. Борисов И.Б. Ведут ли уличные акции к прямому народовластию // Рос. газ. 2009. 20 февраля.

193. Бутаев В.И., Загуляева Л.А., Райков Г.И. Взаимодействие избирательных комиссий и органов внутренних дел по обеспечению прав граждан и правопорядка на выборах и референдумах. Методическое пособие. М.: ЦИК России, 2009. 32 с.

194. Вавилов C.B. О совершенствовании системы международного сотрудничества в области демократических выборов // Журнал о выборах. 2008. № 6. C. 17-19.

195. Вавилов С.В. Выборы в эпоху перемен // Рос. газ. 2010. 1 июля.

196. Варламова Н.В., Лукашева Е.А., Мальщев Г.В. и др. Право и политика современной России. М.: Былина, 1996. 215 с.

197. Веденеев Ю.А., Лысенко В.И. Политика и федеральные выборы (К вопросу о взаимоотношениях между властью и правом) // Государство и право. 1995. № 2. C. 77-87.

198. Веденеев Ю.А. Политические партии в избирательном процессе: правовые иллюзии и юридическая реальность // Государство и право. 1995. № 7. C. $19-28$.

199. Веденеев Ю.А. Развитие избирательной системы Российской Федерации: проблемы правовой институционализации // Журнал российского права. 2006. № 6. С. 47-57.

200. Ведерников H.T. Конституционный суд и правовая защита конституционного строя // Конституционный вестник. 1991. № 8. М.: Изд-во Конституционной комиссии России. С. 44-47.

201. Ведерников Н.T. Государство и личность в конституционном праве России /Актуальные проблемы современного российского государствоведения. 2008. Вып. 1. / Под ред. С.Н. Бабурина М.: Изд-во РГТЭУ, 2008. С. 48-61.

202. Ведерников Н.T., Петренко Д.С. Конституционное правосудие (исторические, теоретические и организационные основы). Монография. М.: Издво РГТЭУ, 2009. 323 с.

203. Ведерников H.T., Моисеев A.M. Соблюдение конституционного принципа свободы деятельности общественных объединений при реализации права граждан на объединение в политические партии / Румянцевские чтения. Государство и церковь: конституционно-правовые и богословские проблемы. М.: Изд-во РГТЭУ, 2009. С. 79-90.

204. Вешняков A.A. Новые избирательные технологии и проблемы наблюдения за выборами // Журнал о выборах. М.: Российский центр обучения избирательным технологиям при ЦИК России, 2005. № 3. С. 54-59.

205. Вешняков A.A. Общая характеристика гарантий обеспечения избирательных прав граждан с использованием ГАС «Выборы» // Конституционное и муниципальное право. М.: Юрист, 2006. № 8. С. 2-9.

206. Волков В.П., Дамаскин О.В., Шапиев С.М. Некоторые проблемы и пути их решения для обеспечения законности избирательного процесса в Российской Федерации. М.: РЦОИТ, 2009. 288 с. 
2005.

207. Выборы в Российской Федерации. 2004. Электоральная статистика. М.,

208. Выборы в Российской Федерации. 2007. Электоральная статистика / Центральная избирательная комиссия Российской Федерации. М.: СитиПрессСервис, 2008. 200 с.

209. Выборы Президента Российской Федерации. 2008: Сборник информационно-аналитических материалов / Центральная избирательная комиссия Российской Федерации. М.: СитиПрессСервис, 2008. 328 с.

210. Выборы в субъектах Российской Федерации 2 марта 2008 года и в единые дни голосования 12 октября 2008 года, 1 марта 2009 года: Электоральная статистика. М.: ЦИК России, 2009. 228 с.

211. Гальвина И.Н. Охрана и защита конституционного строя Российской Федерации. Автореф. дис. ... канд. юрид. наук. Челябинск, 2006.

212. Дамаскин O.B. Легитимация результатов избирательного процесса в Российской Федерации // Журнал о выборах. 2008. № 3. С. 14-19.

213. Дамаскин О.В., Красинский В.В., Сеченова Р.Р., Фахретдинова А.И. Прокуратура в системе обеспечения конституционной законности избирательного процесса в интересах безопасности государственного строительства. Научнометодическое пособие. М.: НИИ проблем укрепления законности и правопорядка при Генеральной прокуратуре РФ, 2005. 82 с.

214. Дамм И.А. Коррупция в российском избирательном процессе: понятие и противодействие. Автореф. дис. ... канд. юрид. наук. Красноярск, 2006. С. 15.

215. Дзлиев М.И., Романович А.Л., Урсул А.Д. Проблемы безопасности: теоретико-методологические аспекты. М.: Изд-во МГУК, 2001. 192 с.

216. Дмитриев Ю.А. Будет ли в России цивилизованная партийная система? // Право и политика. 2001. № 4. С. 136-139.

217. Дмитриев Ю.А. Экстремизм не пройдет? // Современное право. 2006. № 9. C. 45-47.

218. Дмитриев Ю.А., Исраелян В.Б. Избирательное право и процесс в Российской Федерации. Ростов-на-Дону. Феникс, 2004. 864 с.

219. Жиляев A.B. Правовые и организационные основы осуществления иностранного (международного) наблюдения за выборами в Российской Федерации. Дис. ... канд. юрид. наук. Омск, 2006. 188 с.

220. Зорькин В.Д. Угрозы международной и национальной безопасности и ограничение прав человека в практике конституционного правосудия // Российское правосудие. 2006. № 2. С. 3-13.

221. Зорькин В.Д. Об угрозах конституционного строя в XXI веке и необходимости проведения правовой реформы в России // Журнал российского права. 2004. № 6. С. 3-17.

222. Иванченко A.B., Прудникова Т.А. Конституционно-правовые гарантии от монополизации власти // Вестник Московского университета МВД России. 2004. № 2. С. 36-39.

223. Игнатенко B.B. Юридическая ответственность и избирательный процесс. М.: РЦОИТ, 2003. 143 с.

224. Идрисов Р.Ф. Теоретические и правовые проблемы обеспечения национальной безопасности Российской Федерации. Дис. ... д-ра юрид. наук. М., 2002. $401 \mathrm{c}$.

225. Избирательное законодательство и выборы в современном мире / В.И. Лысенко, А.Г. Головин. М.: МедиаПресс, 2009. 528 с. 
226. Избирательное право и избирательный прощесс в решениях Конституционного Суда Российской Федерации. 2000-2007. В 2 т. М.: Центральная избирательная комиссия Российской Федерации, 2008.

227. Избирательные права и право на участие в референдуме граждан Российской Федерации в решениях Верховного Суда Россииской Федерации. 2003. В 2 т. / Отв. ред. В.И.Казьмин. М.: Центральная избирательная комиссия Российской Федерации, 2004.

228. Избирательные права и право на участие в референдуме граждан Российской Федерации в решениях Верховного Суда Россииской Федерации. 2004. В 2 т. / Отв. ред. В.И.Казьмин. М.: Центральная избирательная комиссия Российской Федерации, 2005.

229. Избирательная реформа: опыт, проблемы, перспективы / Под ред. В.И. Васильева. М.: Манускрипт, 1993. 258 с.

230. Керимов Д.А. Избранные произведения. В 3 т. Т. 1. М.: Изд. дом Академия, 2007. $432 \mathrm{c}$.

231. Керимов Д.А. Избранные произведения. В 3 т. Т. 2. М.: Изд. дом Академия, 2007. $376 \mathrm{c}$.

232. Керимов Д.А. Избранные произведения. В 3 т. Т. 3. М.: Изд. дом Академия, 2007. $416 \mathrm{c}$.

233. Керимов Д.А., Керимов А.Д. Методология права в контексте всеобщей методологии познания // Политика и общество. 2009. № 11. С. 4-9.

234. Керимов А.Д. Некоторые проблемы участия политических партий в выборах в органы государственной власти // Право и политика. 2001. № 1. С. 1922 .

235. Керимов А.Д. Почему властвует меньшинство? // Политика и общество. 2007. № 6. С. 49-55.

236. Керимов А.Д. Современное государство: вопросы теории. М.: Норма, 2007. $144 \mathrm{c}$.

237. Климова Ю.Н. Взаимодействие избирательной комиссии с правоохранительными органами при обеспечении законности и правопорядка на территории избирательного округа // Вестник ЦИК России. 2006. № 11.

238. Ковлер А.И. Избирательные технологии: российский и зарубежный опыт. М.: Изд-во РАН Институт государства и права, 1995. 116 с.

239. Коврижных A.A. Обеспечение информационной безопасности подготовки и проведения выборов (референдума) в условиях применения Государственной автоматизированной системы Российской Федерации «Выборы»: Дис. ...канд. юрид. наук. М., 2004. 179 с.

240. Колюшин Е.И. Судебная защита избирательных прав граждан. М.: Городец, 2005. $144 \mathrm{c}$.

241. Колюшин Е.И. Концепция модернизации избирательного и связанного с ним законодательства // Вестник Московского университета. 2010. № 1. С. 68-78.

242. Колюшин Е.И. Выборы и избирательное право в зеркале судебных решений. М.: Норма, 2010. 384 с. $170 \mathrm{c}$.

243. Конституционный строй России. Выпуск первый. М.: ИГП РАН, 1992.

244. Конституционный строй России. Выпуск второй. М.: ИГП РАН, 1995. $130 \mathrm{c}$.

245. Конституционный строй России. Выпуск третий. М.: ИГП РАН, 1996. 110 c. 

$180 \mathrm{c}$.

246. Конституционный строй России. Выпуск четвертый. М.: ИГП РАН, 2003.

247. Красинский B.B. Правовое обеспечение избирательного процесса в интересах национальной безопасности России. Монография. Тамбов, 2009. 466 с.

248. Красинский В.В. Юридическое обеспечение выборов в интересах защиты конституционного строя и национальной безопасности. Учебное пособие. М.: Новый индекс, 2010. 552 с.

249. Кузьмин В. Роль США в осуществлении «цветных революций» в зарубежных странах // Зарубежное военное обозрение. 2008. № 9 (738). С. 9-18.

250. Лысенко В.И. Проблемы современного избирательного права в России и в европейских странах: Дис. ... д-ра. юрид. наук / РАН Институт государства и права. М., 1995. 35 с.

251. Лысенко В.И., Евланов И.А. Выборы - по демократическим стандартам // Журнал о выборах. 2005. № 3. С. 58-59.

252. Лысенко В.И., Евланов И.А. Новый шаг в развитии международных избирательных стандартов // Журнал о выборах. 2008. № 6. С. 8-16.

253. Маклаков B.B. Политическое поведение избирателей во Франции // Советское государство и право. 1974. № 3. С. 108-113.

254. Мальцев Г.В., Носов С.И. Коррупциогенные факторы в юридических нормах: природа, формы проявления, проблемы устранения // Право и образование. 2009. № 1. С. 4-12.

255. Мамонов B.B. Конституционные основы национальной безопасности Российской Федерации. Дис. ... д-ра юрид. наук. Саратов, 2004. 411 с.

256. Марина E.M., Фомин A.A. Обеспечение Конституционным Судом Российской Федерации правовой безопасности участников избирательного процесса / Актуальные проблемы политики и права. Межвузовский сборник научных статей. Вып. 6. Пенза, 2003. С. 188-192.

257. Международные избирательные стандарты. Сб. документов / Отв. ред.: кандидат юрид. наук А.А. Вешняков; науч. ред.: доктор юрид. наук В.И. Лысенко. М.: Издательство Весь Мир, 2004. 1151 с.

258. Международные избирательные стандарты. Сб. документов / Отв. ред.: доктор юрид. наук В.И. Лысенко. М.: ЦИК России, 2009. 1248 с.

259. Митюков М.A. Конституционные суды постсоветских государств: контроль за выборами и референдумом / Конституционное правосудие в посткоммунистических странах. Сборник докладов. М.: Изд-во Центра конституционных исследований, 1999. С. 42-48.

260. Митюков М.A. Роль конституционного правосудия в укреплении российской государственности / Российское государство и углубление реформ в контексте глобализации мировых процессов, внешних и внутренних угроз безопасности России, борьбы с организованной преступностью и коррупцией. Материалы Всероссийской научно-практической конференции (18-20 апреля 2001 г.) Вып. 1. Калуга, 2001. С. 125-138.

261. Михалева Н.A. Теоретические проблемы социалистической конституции (Сущность, содержание, форма). Дис. ... докт. юрид. наук. М., 1983. 398 c.

262. Михалева Н.А., Морозова Л.А. Реформа республиканского избирательного законодательства (Сравнительно-правовой аспект) // Советское государство и право. 1990. № 6. С. 29-39.

263. Моисеев A.M. Конституционное право граждан на объединение в политические партии и судебная практика его защиты. Автореф. дис. ... канд. юрид. наук. М., 2008. 25 с. 
264. Навальный C.B. Легитимация государственной власти в процессе информационного обеспечения избирательного процесса // Право и государство: теория и практика. 2010. № 4 (64). С. 148-151.

265. Научно-практический комментарий к Федеральному закону «Об основных гарантиях избирательных прав и права на участие в референдуме граждан Российской Федерации» / Отв. ред. канд. юрид. наук А.А. Вешняков; науч. ред. доктор юрид. наук В.И. Лысенко. М.: Объединенная редакция МВД России, 2007. $861 \mathrm{c}$.

266. Научно-практический комментарий к Федеральному закону «О выборах депутатов Государственной Думы Федерального Собрания Российской Федерации» // Отв. ред. канд. юрид. наук А.А. Вешняков; науч. ред. доктор юрид. наук В.И. Лысенко. М., 2007. 784 с.

267. Осавелюк A.M. Вспомогательный аппарат высших органов государственной власти в механизме государства. Автореф. дис. ... докт. юрид. наук. М., 2006. 45 c.

268. Осавелюк А.М. Правовые основы организации и функционирования современной системы государственных органов /Актуальные проблемы современного российского государствоведения. 2008. Вып. 1. / Под ред. С.Н. Бабурина М.: Изд-во РГТЭУ, 2008. С. 219-244.

269. Осавелюк А.M. Регулирование правового статуса человека современным конституционным правом /Актуальные проблемы современного российского государствоведения. 2009. Вып. 2. / Под ред. С.Н. Бабурина М.: Издво РГТЭУ, 2009. С. 172-194.

270. Осавелюк А.М. Регулирование прав человека в условиях светского государства / Румянцевские чтения. Государство и церковь: конституционноправовые и богословские проблемы. М.: Изд-во РГТЭУ, 2009. С. 66-74.

271. Патрушев Н.П. Особенности современных вызовов и угроз национальной безопасности России // Журнал российского права. 2007. № 7. С. 312.

272. Петренко Д.С. Органы конституционного правосудия как участники политических отношений ААктуальные проблемы современного российского государствоведения. 2009. Вып. 2. / Под ред. С.Н. Бабурина М.: Изд-во РГТЭУ, 2009. C. 247-270.

273. Петренко Д.С. Судебный конституционный контроль как важнейший признак современного правового государства / Актуальные проблемы современного российского государствоведения. 2008. Вып. 1. / Под ред. С.Н. Бабурина М.: Изд-во РГТЭУ, 2008. С. 85-108.

274. Политические институты, избирательное право и процесс в трудах российских мыслителей XIX-XX вв.: Хрестоматия / Сост.: Ю.А. Веденеев, И.В. Зайцев, Л.В. Поляков. М.: Весь Мир, 2003. 896 с.

275. Постников A.Е, Алехичева Л.Г. Недействительность выборов: законодательство и судебная практика. М.: Права человека, 2001. 196 с.

276. Постников А.Е. Избирательное законодательство: необходимо четкое разделение полномочий между различными уровнями власти при проведении выборов // Журнал российского права. 2002. № 5. С. 12-22.

277. Правовое обеспечение безопасности Российской Федерации / Под ред. Вишнякова В.Г. М.: Юрид. лит., 2005. 400 с.

278. Правовая основа обеспечения национальной безопасности Российской Федерации / Под ред. Опалева А.В. М.: Юнити-Дана, 2004. 511 с.

279. Румянцев О.Г. Основы конституционного строя: понятие, содержание, отражение в Конституции // Государство и право. 1993. № 10. С. 3-15. 
280. Савин С.Ю. Правовое обеспечение информационной безопасности Государственной автоматизированной системы Российской Федерации «Выборы»: Дис. ...канд. юрид. наук / РАГС при Президенте РФ. М., 2007. 184 с.

281. Современные избирательные системы. Вып. 1: Великобритания, Канада, Мексика, Польша. М.: Норма, 2006. 495 с.

282. Современные избирательные системы. Вып. 2: Аргентина, Германия, Швеция. М.: РЦОИТ: Норма, 2007. 319 с.

283. Современные избирательные системы. Вып. 3: Испания, США, Финляндия, Япония. М.: РЦОИТ: Новости, 2009. 448 с.

284. Современные избирательные системы. Вып. 4: Австралия, Венесуэла, Дания, Сербия. М.: РЦОИТ: Ин-октаво, 2009. 480 с.

285. Сунщов А.П. Правонарушения в избирательной системе субъекта Российской Федерации (конституционно-правовое исследование): Автореф. дис. ... докт. юрид. наук. Екатеринбург, 2000. 40 с.

286. Тихомиров Ю.А. Механизм реализации конституционных норм о политических институтах / Государственно-правовые проблемы реализации советской Конституции. Межвузовский сборник научных трудов. Свердловск.: Изд-во Свердл. юрид. ин-та, 1987. С. 45-52.

287. Тихомиров Ю.А., Чиркин В.Е. Основы теории политической системы. М.: Наука, 1985. $248 \mathrm{c}$.

288. Ткачева Н.А. Проблема гарантированности основ конституционного строя. Дис. ... канд. юрид. наук. Ставрополь, 2004. 179 с.

289. Топорнин Б.Н. Конституционные основы политической системы советского общества. М.: Московский рабочий, 1978. 136 с.

290. Урсул А.Д., Романович А.Л. Безопасность и устойчивое развитие (философско-концептуальные проблемы). М.: Изд-во РАГС, 2001. 128 с.

291. Усанов B.A. Многопартийность как необходимое условие парламентаризма и основа конституционного строя // Право и жизнь. 2005. № 85. C. $17-42$.

292. Хабриева Т.Я. Правовая охрана конституции. Монография. Казань.: Издво Казан. ун-та, 1995. 220 с.

293. Хабриева Т.Я. Национальные интересы и российское законодательство // Право и безопасность. 2005. № 4. С. 71-79.

294. Хабриева Т.Я., Чиркин В.Е. Теория современной конституции. М.: Норма, 2005. $320 \mathrm{c}$.

295. Царев Д.В. Защита основ государственной власти в нормах Конституции и УК РФ // Иваново-Вознесенский юридический вестник. 2003. № 11-12. C. 9-12.

296. Чиркин B.E. Легализация и легитимация государственной власти // Государство и право. 1995. № 8. С. 65-73.

297. Чиркин B.E. Какая избирательная система нужна России // Законодательство и экономика. 2005. № 1. С. 5-11.

298. Шемелин А.В. Проблемы реализации международных избирательных стандартов и имплементации зарубежных избирательных моделей в России // История государства и права. 2009. № 20. С. 29-31.

299. Щетинин Б.В. Советская избирательная система. М.: Знание, 1974. 64 с.

300. Янюшкин А.С. Политические основы конституционного строя Российской Федерации в конституциях и уставах субъектов Российской Федерации. Автореф. дис. ... канд. юрид. наук. М., 2009. 20 с. 


\section{Ф Е Д Е Р А Л Ь Н Ы Й З А К О Н №}

\section{«О внесении изменений в законодательные акты Российской Федерации о выборах и референдумах и иные законодательные акты Российской Федерации»}

\section{Принят Государственной Думой \\ Одобрен Советом Федерации}

Статья 1. Внести в Федеральный закон от 12 июня 2002 г. № 67-Ф3 «Об основных гарантиях избирательных прав и права на участие в референдуме граждан Российской Федерации» (С3 РФ. 2002. № 24. Ст. 2253) следующие изменения:

1. Пункт 6 статьи 1 изложить в редакции:

«Конституции (уставы), законы субъектов Российской Федерации, иные нормативные правовые акты о выборах и референдумах, принимаемые в Российской Федерации, не должны противоречить настоящему Федеральному закону. Если конституция (устав), закон субъекта Российской Федерации, иной нормативный правовой акт о выборах и (или) референдуме противоречат настоящему Федеральному закону, применяются нормы настоящего Федерального закона.

2. Пункт 58 статьи 2 изложить в редакции: «Сведения о судимостях кандидата - сведения о судимостях с указанием номера (номеров) и наименования (наименований) статьи (статей) Уголовного кодекса Российской Федерации, на основании которой (которых) был осужден кандидат, наименования суда, вынесшего приговор, срока и вида наказания, даты освобождения, а также статьи (статей) уголовного кодекса, принятого в соответствии с Основами уголовного 
законодательства Союза ССР и союзных республик, статьи (статей) закона иностранного государства, если кандидат был осужден в соответствии с указанными законодательными актами за деяния, признаваемые преступлением действующим Уголовным кодексом Российской Федерации».

3. Пункт 4 статьи 21 дополнить предложением:

«Политические партии, федеральные списки кандидатов которых не допущены к распределению депутатских мандатов в Государственной Думе Федерального Собрания Российской Федерации, а также региональные отделения этих политических партий, списки кандидатов которых не допущены к распределению депутатских мандатов в законодательных (представительных) органах государственной власти субъектов Российской Федерации, могут назначить по одному представителю от каждой партии для участия в работе Центральной избирательной комиссии Российской Федерации с правом совещательного голоса».

4. Пункт 1 статьи 22 изложить в редакции:

«Избирательные комиссии субъектов Российской Федерации, избирательные комиссии муниципальных образований, окружные избирательные комиссии, территориальные, участковые комиссии формируются на основе предложений политических партий, выдвинувших списки кандидатов на выборах в Государственную Думу Федерального Собрания Российской Федерации, законодательный $\quad$ (представительный) орган государственной $\quad$ власти соответствующего субъекта Российской Федерации».

5. Пункт 2 статьи 22 изложить следующим образом:

«Избирательные комиссии муниципальных образований, окружные избирательные комиссии по выборам в органы местного самоуправления, территориальные, участковые комиссии формируются на основе предложений, указанных в пункте 1 настоящей статьи, а также предложений избирательных объединений, выдвинувших списки кандидатов на выборах в представительный орган муниципального образования». 
6. Внести изменение в статью 32 и дополнить пункт 3.2 предложением следующего содержания:

«Граждане, не являющиеся членами избирательных объединений, должны составлять не менее $10 \%$ от числа кандидатов, включенных в соответствующие списки кандидатов».

7. Внести изменения в статьи 49 и 53, дополнив их пунктами 3.1 и 7.1 следующего содержания:

«Запрещается проведение публичных мероприятий с момента окончания агитационного периода до официального опубликования результатов выборов».

8. Первый абзац подпункта «п» пункта 6 статьи 58 изложить следующим образом: «некоммерческим организациям, получавшим в течение двух лет, предшествующих дню внесения пожертвования в избирательный фонд, фонд референдума, денежные средства либо иное имущество от:» (далее - без изменений).

9. Пункт 11 статьи 64 дополнить предложением:

«Не допускается вынос избирательных бюллетеней из помещения для голосования».

10. Из пункта 15 статьи 64 исключить следующее предложение: «Общее число избирательных участков, участков референдума, где проводится электронное голосование, не должно превышать 1 процент от числа избирательных участков, участков референдума, образованных на территории, на которой проводятся выборы, референдум, а если 1 процент от числа избирательных участков, участков референдума, образованных на территории, на которой проводятся выборы, референдум, составляет менее пяти избирательных участков, участков референдума, указанное общее число не может быть менее пяти избирательных участков, участков референдума».

11. Пункт 6 статьи 70 изложить в следующей редакции:

«Соответствующая избирательная комиссия после определения результатов выборов извещает об этом зарегистрированного кандидата, избранного депутатом, выборным должностным лицом, после чего он обязан в пятидневный 
срок представить в соответствующую избирательную комиссию копию приказа (иного документа) об освобождении его от обязанностей, несовместимых со статусом депутата, выборного должностного лица, либо копии документов, удостоверяющих подачу в установленный срок заявления об освобождении от указанных обязанностей. Если зарегистрированный кандидат, признанный избранным по результатам голосования за список кандидатов, не выполнит указанное требование или откажется от мандата, он исключается из списка кандидатов, а его депутатский мандат считается вакантным. При этом такой мандат не может быть передан другому зарегистрированному кандидату из того же списка кандидатов, в составе которого был избран депутат, который не выполнил требования об освобождении его от обязанностей, несовместимых со статусом депутата, либо отказался от мандата. Вакантный мандат передается следующему в порядке убывания числа поданных голосов избирателей списку кандидатов. Если зарегистрированный кандидат, избранный депутатом по одномандатному (многомандатному) избирательному округу либо избранный выборным должностным лицом, не выполнит указанное требование, соответствующая избирательная комиссия отменяет свое решение о признании кандидата избранным».

12. Пункт 7 статьи 70 изложить в следующей редакции:

«Законом может быть предусмотрено, что, если кандидат без вынуждающих к тому обстоятельств не сложил с себя полномочия, несовместимые со статусом депутата, выборного должностного лица, в результате чего назначены повторные выборы, этот кандидат должен полностью возместить соответствующей избирательной комиссии произведенные ею расходы, связанные с проведением повторных выборов. Соответствующий закон должен также содержать перечень обстоятельств, при которых указанное возмещение не производится».

Статья 2. Внести в Федеральный закон от 18 мая 2005 г. № 51-Ф3 «О выборах депутатов Государственной Думы Федерального Собрания Российской Федерации» (С3 РФ. 2005. № 21. Ст. 1919) следующие изменения:

1. Часть 6 статьи 36 изложить в редакции: 
«Политическая партия обязана включать в федеральный список кандидатов лиц, не являющихся членами политических партий. Указанные лица составляют не менее $10 \%$ от числа кандидатов, включенных в федеральный список кандидатов».

2. Первый абзац подпункта 16 части 7 статьи 64 изложить следующим образом: «некоммерческим организациям, получавшим в течение двух лет, предшествующих дню внесения пожертвования в избирательный фонд, фонд референдума, денежные средства либо иное имущество от:».

3. Часть 12 статьи 75 дополнить предложением:

«Не допускается вынос избирательных бюллетеней из помещения для голосования».

4. Статью 84 дополнить частью 2 в следующей редакции: «При проведении повторных выборов депутатов Государственной Думы Федерального Собрания Российской Федерации не допускается выдвижение и регистрация федеральных списков кандидатов политическими партиями, действия (бездействие) руководителей и уполномоченных представителей которых послужили (послужило) основанием для признания выборов недействительными».

Статья 3. Внести в Федеральный закон от 10 января 2003 г. № 19-Ф3 «О выборах Президента Российской Федерации» (СЗ РФ. 2003. № 2. Ст. 171) следующие изменения:

1. Первый абзац подпункта 15 пункта 6 статьи 58 Федерального закона «О выборах Президента Российской Федерации» изложить в редакции:

«некоммерческим организациям, получавшим в течение двух лет, предшествующих дню внесения пожертвования в избирательный фонд, фонд референдума, денежные средства либо иное имущество от:».

2. Пункт 12 статьи 69 Федерального закона «О выборах Президента Российской Федерации» дополнить предложением:

«Не допускается вынос избирательных бюллетеней из помещения для голосования». 
Статья 4. Изложить статью $16^{1}$ Закона Российской Федерации от 27 декабря 1991 г. № 2124-1 «О средствах массовой информации» (Ведомости СНД и ВС РФ. 1992. № 7. Ст. 300) в следующей редакции:

«Если в период избирательной кампании после вступления в силу решения суда о привлечении главного редактора или редакции радио-, телепрограммы, периодического печатного издания, иной организации, осуществляющей выпуск СМИ, к административной ответственности за нарушение законодательства о выборах этот главный редактор или эта организация допустит повторное нарушение законодательства о выборах, ЦИК России (в случае, если продукция СМИ распространяется на территории субъекта Российской Федерации также избирательная комиссия соответствующего субъекта Российской Федерации) обращается в федеральный орган исполнительной власти, осуществляющий регистрацию СМИ, с представлением о приостановлении выпуска данного СМИ. Указанный федеральный орган исполнительной власти немедленно осуществляет проверку фактов, изложенных в представлении, и обращается в суд с заявлением о приостановлении выпуска СМИ, использованного в целях совершения указанных нарушений. Приостановление выпуска СМИ осуществляется судом на срок до момента окончания голосования на выборах, а в случае, если проводится повторное голосование, - до момента окончания повторного голосования».

Статья 5. Дополнить статью 9 Федерального закона от 19 июня 2004 г. № 54-Ф3 «О собраниях, митингах, демонстрациях, шествиях и пикетированиях» (С3 РФ. 2004. № 25. Ст. 2485) следующим предложением: «Запрещается проведение публичных мероприятий с момента окончания агитационного периода до официального опубликования результатов выборов».

Статья 6. Внести в Федеральный закон от 12 января 1996 г. № 7-Ф3 «О некоммерческих организациях» (С3 РФ. 1996. № 3. Ст. 145) следующие изменения:

1. Дополнить статью 18 пунктом 2.2: «Ликвидация иностранной некоммерческой неправительственной организации (ее структурного подразделения) в связи с несоответствием характера деятельности заявленным 
целям влечет за собой лишение права осуществлять деятельность на территории Российской Федерации сроком на 5 лет».

2. Пункт 12 статьи 32 дополнить предложением: «Ликвидация иностранной некоммерческой неправительственной организации (eе структурного подразделения) в связи с несоответствием характера деятельности заявленным целям влечет за собой лишение права осуществлять деятельность на территории Российской Федерации сроком на 5 лет».

Статья 7. Внести в Кодекс Российской Федерации об административных правонарушениях от 30 декабря 2001 г. № 195-Ф3 (С3 РФ. 2002. № 1 (Часть 1). Ст. 1) следующие изменения:

1. Ввести статью 5.2 «Нарушение запрета на вынос избирательных бюллетеней из помещения для голосования» в следующей редакции: «Нарушение запрета на вынос избирательных бюллетеней из помещения для голосования влечет наложение административного штрафа в размере от одной тысячи до двух тысяч пятисот рублей на граждан; на должностных лиц - от трех тысяч до четырех тысяч рублей».

2. Ввести статью 5.16.1 «Получение избирателем (участником референдума) выгоды материального и (или) нематериального характера за осуществление волеизъявления» следующего содержания:

«Заполнение избирателями (участниками референдума) подписных листов в поддержку кандидата (списков кандидатов), в поддержку инициативы проведения референдума, голосование за кандидата (список кандидатов), голосование на референдуме либо отказ от голосования, совершенные с целью извлечения выгод материального и (или) нематериального характера, влечет наложение административного штрафа в размере от трех тысяч до пяти тысяч рублей».

3. Ввести статью 5.25.1 «Нарушение иностранным (международным) наблюдателем порядка наблюдения за подготовкой и проведением выборов, референдума» следующего содержания:

«1. Выдвижение иностранным (международным) наблюдателем незаконных требований о непризнании итогов выборов (референдума), а равно 
распространение заведомо ложной информации, связанной с подготовкой и проведением выборов (референдума) - влекут за собой наложение административного штрафа в размере до 20 минимальных размеров оплаты труда и отзыв аккредитации.

2. Те же нарушения, совершенные иностранными (международными) наблюдателями, обладающими привилегиями и иммунитетами в соответствии с нормами международного права - влекут за собой отзыв аккредитации».

Статья 8. Настоящий закон вступает в силу со дня его официального опубликования.

Президент Российской Федерации

Москва, Кремль 